\title{
Rapid Subsidence and Historical Wetland Loss in the Mississippi Delta Plain: Likely Causes and Future Implications
}

By Robert A. Morton, Julie C. Bernier, John A. Barras, and Nicholas F. Ferina
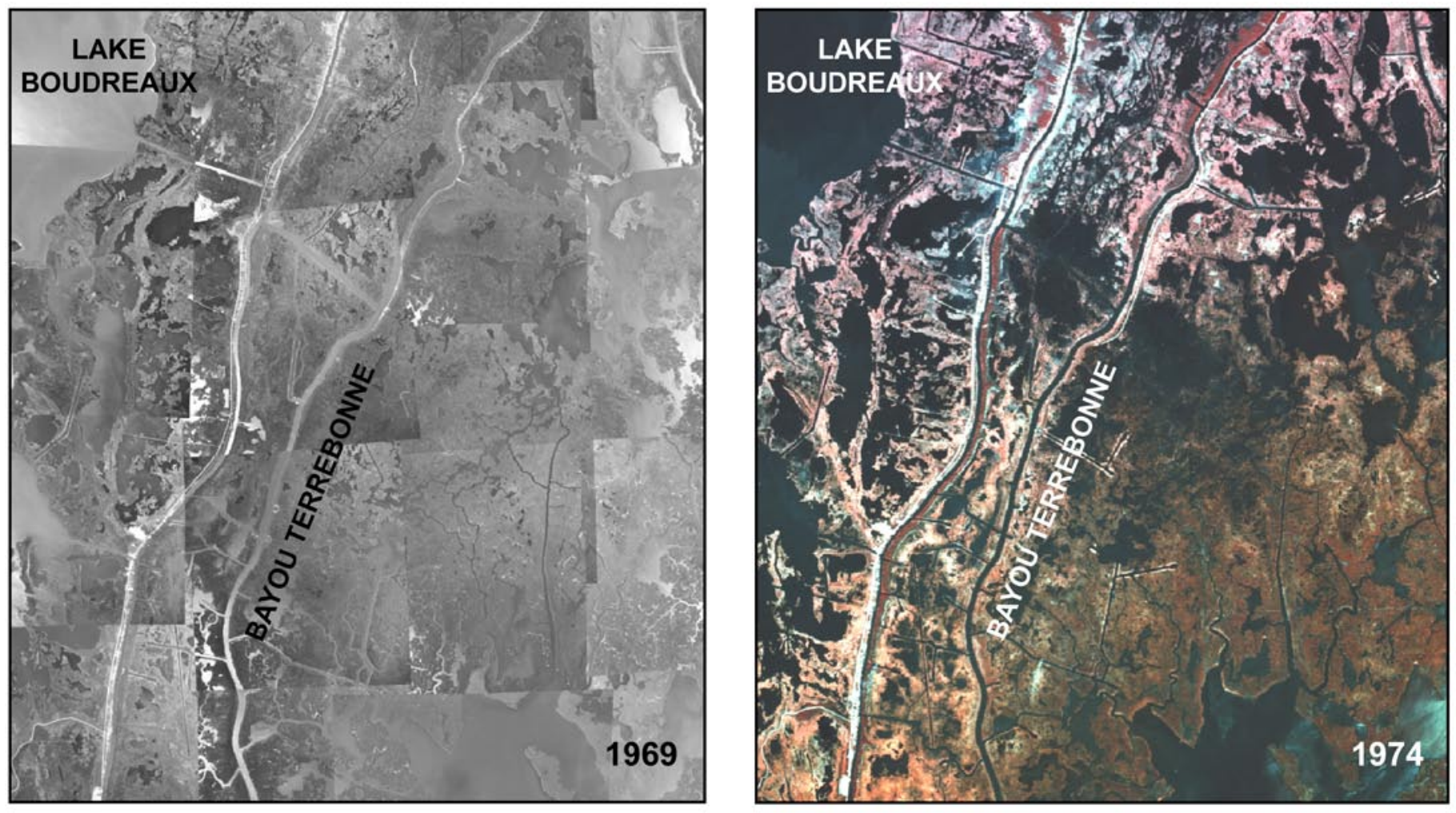

Open-File Report 2005-1216

U.S. Department of the Interior

U.S. Geological Survey 



\section{Rapid Subsidence and Historical Wetland Loss in the Mississippi Delta Plain: Likely Causes and Future Implications}

By Robert A. Morton', Julie C. Bernier², John A. Barras ${ }^{3}$, and Nicholas F. Ferina'

1 U.S. Geological Survey

Center for Coastal and Watershed Studies

600 4th St. S., St. Petersburg, FL 33701

${ }^{2}$ Environmental Careers Organization

600 4th St. S., St. Petersburg, FL 33701

${ }^{3}$ U.S. Geological Survey

National Wetlands Research Center

Baton Rouge, LA 70894

Front cover photographs: land change and wetland loss at Madison Bay, Terrebonne Parish, Louisiana between 1969 and 1974. Scale 1:125,000.

Open-File Report 2005-1216 



\section{Contents}

Summary

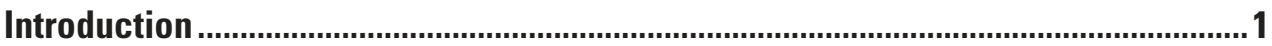

Imagery Sources and Classification Methods ................................................... 1

Aerial-Photograph Rectification and Land-Water Classification .................................. 3

Landsat Thematic Mapper Land-Water Classification ............................................... 4

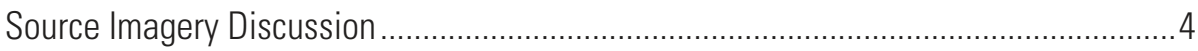

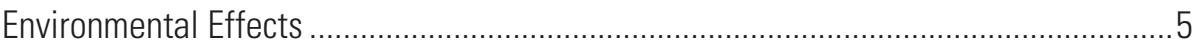

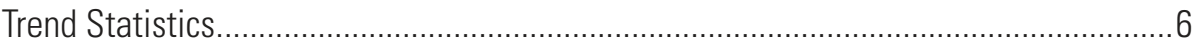

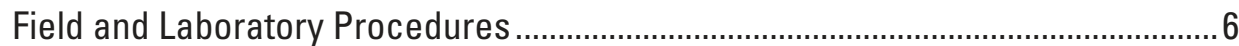

Water-Level Measurements and Corrections .............................................................. 6

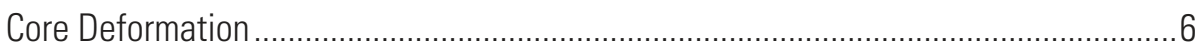

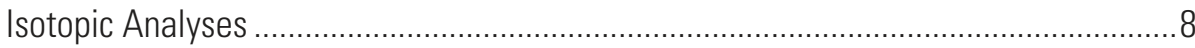

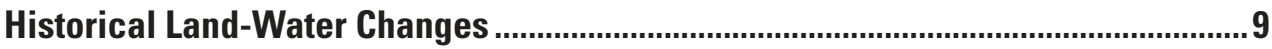

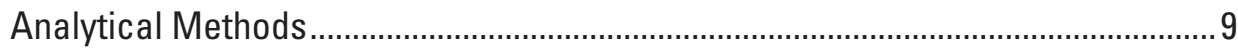

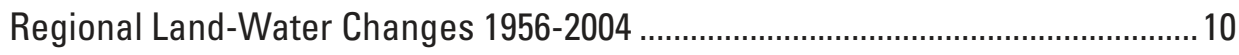

Sediment Types and Depositional History................................................................... 12

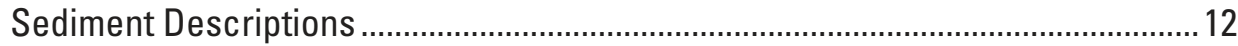

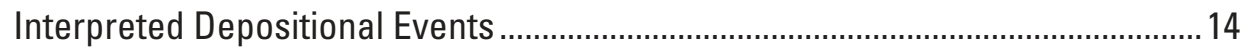

Historical Subsidence and Erosion of Delta-Plain Marshes ...................................15

Methods of Estimating Subsidence and Erosion ................................................... 15

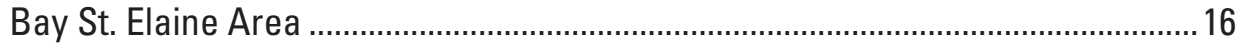

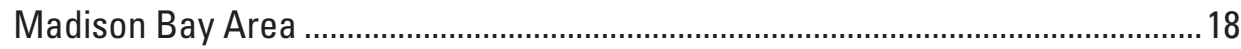

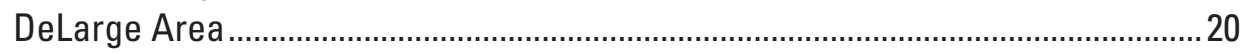

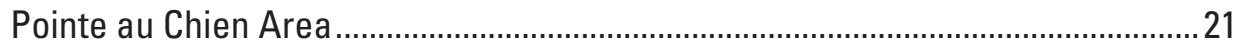

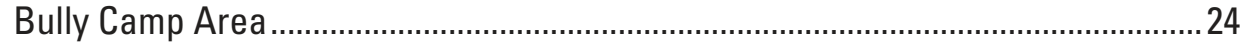

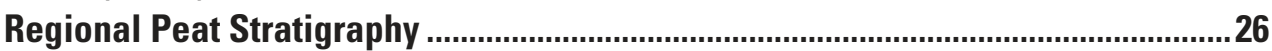

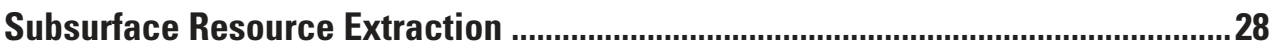

Fluid Production near Coring Sites ............................................................... 28

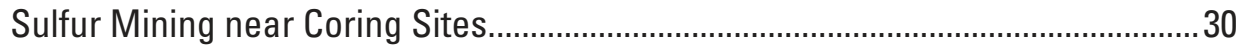

Geological and Historical Rates of Subsidence ...............................................31

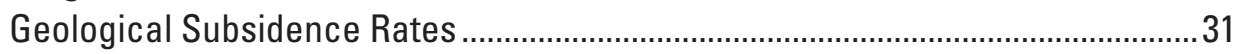

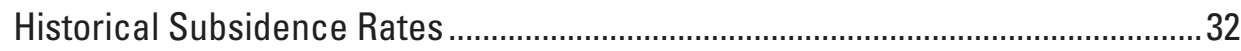

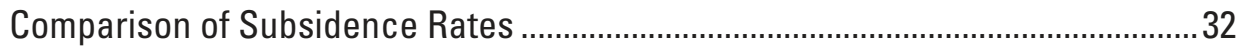

Trends of Subsidence, Wetland Loss, and Resource Extraction ............................34

Status of Subsidence Prediction............................................................................34

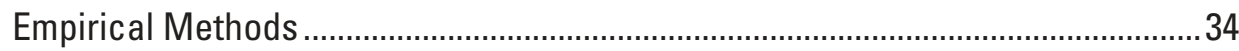

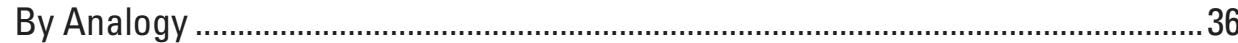

Conclusions and Implications ................................................................................38

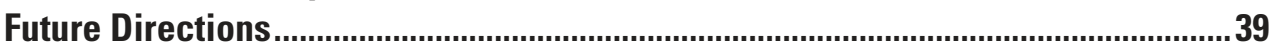

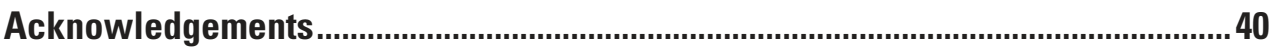

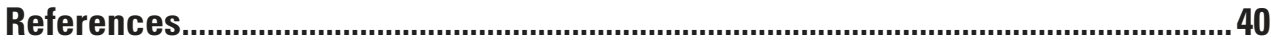

APPENDIX 1: CORE DESCRIPTIONS AND PHOTOGRAPHS ................................43

APPENDIX 2: CORE SHORTENING AT BAY ST. ELAINE ......................................116 


\section{Figures}

Figure 1. Regional map of south-central Louisiana showing locations of coring sites, boundaries of areas used for image analysis of land-water changes, and subdeltas of the Lafourche delta system.

Figure 2. Regional map of south-central Louisiana showing locations of coring sites, the USACE Cocodrie tide gauge, the LDNR Montegut tide gauge, and the distribution of wetland losses (1956-2004) relative to producing oil-and-gas fields

Figure 3. Composite historical land-water changes between 1956 and 2004 for the selected study areas in south-central Louisiana, with daily, 3-day, and 7-day average water levels recorded at the NOS Grand Isle tide gauge

Figure 4. Water levels recorded at the Cocodrie tide gauge on (A) June 25-27 and (B) September 2-4, 2003, and at the LDNR Montegut tide gauge on (C) June 25-27 and (D) September 2-4, 2003.

Figure 5. Generalized core profile showing the stratigraphic position of shallow deltaic sediments of the Lafourche subdelta.

Figure 6. Locations of sediment cores and sediment-surface profiles from the Bay St. Elaine area superimposed on pre- and post-subsidence aerial photographs taken in (A) 1969, (B) 1974, and (C) 1998.

Figure 7. Combined bathymetric profile and stratigraphic cross section for marsh and open-water cores illustrate the magnitude of subsidence (in $\mathrm{cm}$ ) at the Bay St. Elaine area

Figure 8. Locations of sediment cores and sediment-surface profiles from the Madison Bay area superimposed on pre- and post-subsidence aerial photographs taken in (A) 1969, (B) 1974, and (C) 1998

Figure 9. Combined bathymetric profile and stratigraphic cross section for marsh and open-water cores MB-10 to MB-07 illustrate the magnitude of subsidence and wetland erosion (in $\mathrm{cm}$ ) at the Madison Bay area.

Figure 10. Combined bathymetric profile and stratigraphic cross section for marsh and open-water cores MB-10 to MB-08 illustrate the magnitude of subsidence and wetland erosion (in $\mathrm{cm}$ ) at the Madison Bay area.

Figure 11. Locations of sediment cores and sediment-surface profiles from the DeLarge area superimposed on pre- and post-subsidence aerial photographs taken in (A) 1969, (B) 1974, and (C) 1998.

Figure 12. Combined bathymetric profile and stratigraphic cross section for marsh and open-water cores illustrate the magnitude of subsidence and wetland erosion (in $\mathrm{cm}$ ) at the DeLarge area.

Figure 13. Locations of sediment cores and sediment-surface profiles from the Pointe au Chien area superimposed on aerial photographs taken in (A) 1969, (B) 1974, and (C) 1998.

Figure 14. Combined bathymetric profile and stratigraphic cross section for marsh and open-water cores illustrate the magnitude of subsidence and wetland erosion (in $\mathrm{cm}$ ) at the Pointe au Chien area.

Figure 15. Locations of sediment cores and sediment-surface profiles from the Bully Camp area superimposed on pre- and post-subsidence aerial photographs taken in (A) 1969, (B) 1974, and (C) 1998. 
Figure 16. Combined bathymetric profile and stratigraphic cross section for marsh and open-water cores illustrate the magnitude of subsidence and wetland erosion (in $\mathrm{cm}$ ) at the Bully Camp area.

Figure 17. Bathymetric profile at Bully Camp extending east of the coring sites.

Figure 18. Outline of Bay St. Elaine oil-and-gas field showing 300-m top-of-salt contour where sulfur mining was conducted.

Figure 19. Annual fluid production through 2002 from the Bay St. Elaine field in Terrebonne Parish. 30

Figure 20. Annual fluid production through 2002 from the Lapeyrouse and Bay Baptiste fields in Terrebonne Parish.

Figure 21. Annual fluid production through 2002 from the DeLarge and Bayou Rambio fields in Terrebonne Parish.

Figure 22. Annual fluid production through 2002 from the Bayou Jean la Croix, Lirette, and Montegut fields in Terrebonne Parish.

Figure 23. Annual fluid production through 2002 from the Bully Camp field in Lafourche Parish. 34

Figure 24. Plots of historical subsidence rates along (A) Bayou Lafourche and (B) Bayou Petit Caillou calculated by the National Geodetic Survey from re-leveling of benchmarks (Shinkle and Dokka, 2004).

Figure 25. Composite histories of fluid production from oil-and-gas fields and wetland loss in south Louisiana.

Figure 26. Map showing average subsidence rates between 1965 and 1993 in south Louisiana.

Figure 27. Land surface-subsidence trends in the Houston-Galveston area related to groundwater withdrawal. 


\section{Tables}

Table 1. Source imagery used to analyze land-water changes in south-central Louisiana. ............................. 2

Table 2. Core depths and NAVD88 elevations of stratigraphic markers correlated between cores............. 7-8

Table 3. Radiocarbon ages and carbon-isotope data for organic samples. ................................................... 11

Table 4. Ranges and means of $\delta^{13} \mathrm{C}$ measured in plants from marshes in Barataria Basin, Louisiana (Chmura

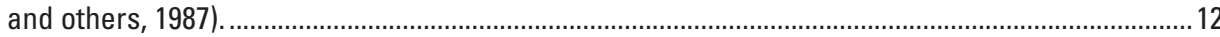

Table 5. Minimum subsidence rates inferred from minimum aggradation rates based on marsh thickness (interval rate) and sample depth (depth rate).

Table 6. Rates (mm/yr) of sediment accumulation (sed) and inferred rates of subsidence (sub) for the Terrebonne and Barataria Basins.

Table 7. Summary of composite land - water conditions for the five study areas in south-central Louisiana between 1956 and 2004 . 


\section{Summary}

Five representative areas of the Mississippi River delta plain were investigated using remote images, marsh elevations, water depths, sediment cores, and radiocarbon dates to estimate the timing, magnitudes, and relative rates of marsh erosion and land subsidence at geological and historical time scales. In the Terrebonne-Lafourche region of rapid interior-wetland loss, former marshes are now submerged beneath water that averages 0.5 to $1.0 \mathrm{~m}$ deep. Most of the permanent historical flooding was caused by rapid subsidence and collapse of the delta plain that occurred during the late 1960s and 1970s. Subsequent erosion of the submerged delta-plain marsh was relatively minor at most of the coring sites. Estimates of wetland-loss rates since 1956 are variable owing to temporal changes in land area and fluctuations in water levels that introduce about $\pm 5 \%$ uncertainty. Despite the uncertainty, the most recent wetland-loss rates are substantially lower than those recorded during the 1969 to 1974-1978 period.

Widespread nearly simultaneous collapse of marshes across the Mississippi delta plain appears to be unprecedented and not repeated in the geological record of the past 1,000 years. Surface and subsurface data strongly indicate that the rapid subsidence and associated wetland loss were largely induced by extraction of hydrocarbons and associated formation water with some subsidence controlled locally by sulfur mining at a few sites. Average historical rates of subsidence between 1965 and 1993 were about 8-12 mm/yr, whereas average geological rates of subsidence for the past 5,000 years were about $1-5 \mathrm{~mm} / \mathrm{yr}$. Natural processes such as deep-seated salt migration and fault movement cannot be discounted entirely, but there is no compelling evidence that they were responsible for the observed historical changes. Results of this study provide a basis for determining the relative importance of subsidence and shoreline erosion as causes of past wetland loss and for predicting sites and probable mechanisms of future wetland loss. This information should improve the selection of project sites and designs for wetland-loss mitigation and coastal restoration.

\section{Introduction}

The magnitude, rate, and timing of wetland loss in south Louisiana and the identification of the underlying processes that cause historical wetland loss have been high-priority topics of scientific investigation since the 1980s. These issues take on even greater importance and urgency considering the state is seeking federal funds reported to be in the $\$ 18$ billion range to restore parts of coastal Louisiana and compensate for some of the historical wetland loss. There are two major challenges that remain for researchers responsible for providing the scientific data used to formulate public policy regarding wetland loss and coastal restoration in Louisiana. The first is generating subsidence estimates for wetland areas that are not immediately adjacent to benchmarks and tide gauges, which is where subsidence rates have been determined previously. The second challenge is developing accurate models for predicting areas and rates of future subsidence and wetland loss.

This report addresses the general lack of subsidence estimates away from levee roads and marina facilities by applying the field and laboratory methods of Morton and others (2003) to four additional areas of historical wetland loss. The second challenge is not addressed directly because the most recent subsidence rates (since 1993) are not available. The National Geodetic Survey (NGS) recently conducted GPS surveys of benchmark elevations in south Louisiana; therefore, derived rates of subsidence should be available in the near future.

The purpose of this study is to examine further the timing and processes involved in subsidence and wetland loss in coastal Louisiana. This was accomplished by: (1) establishing detailed rates of land-water changes and patterns of wetland submergence at representative areas of extensive wetland loss across the south-central Mississippi delta plain, (2) estimating magnitudes of recent subsidence and erosion at these same selected areas, and (3) comparing the temporal and spatial trends of wetland change to historical trends of subsurfaceresource extraction in the same areas.

\section{Imagery Sources and Classification Methods}

Data sets and remotely sensed images depicting the spatial distribution of land and water for south-central Louisiana were obtained from various sources (Table 1) and were used to quantify land-water conditions for 28 dates between 1956 and 2004 for the five study areas (Figs. 1 and 2). The 1956 (baseline), 1978, and 1988 land-water conditions were derived from modified National Wetlands Inventory (NWI) habitat data (Wicker, 1980; Barras and others, 1994) previously used to assess historical trends of land loss and gain for coastal Louisiana (Barras and others, 2003). Landsat Thematic Mapper (TM) land-water classifications for Nov. 1, 1990, Nov. 18, 1999, and Feb. 27, 2002 previously used to identify recent loss and gain trends for coastal Louisiana (Barras and others, 2003) provided additional data points. These historical data provided trend information over a range of dates, but additional dates were needed to make the analysis more complete. Consequently, additional aerial photographs and TM images were acquired to provide better definition of temporal trends for the study areas. The 1968-69 panchromatic (PAN) photographs acquired from the U.S. Army Corps of Engineers (USACE), New Orleans District, and the 1974 color-infrared (CIR) photographs acquired from NASA by the National 


\begin{tabular}{|c|c|c|c|}
\hline Date & Data Type / Sensor & $\begin{array}{c}\text { Scale / Spatial } \\
\text { Resolution }\end{array}$ & Source \\
\hline \multicolumn{4}{|c|}{ Historical Data } \\
\hline 1956 & NWI habitat data & $1: 24000$ & USGS \\
\hline Oct. 1978 & NWI habitat data & $1: 24000$ & USGS \\
\hline Nov. 21, 1988 & NWI habitat data & 1:24000 & USGS \\
\hline \multicolumn{4}{|c|}{ Aerial Photography } \\
\hline $\begin{array}{l}\text { Dec. 15, } 1968 \\
\text { and Mar. } 1969 *\end{array}$ & $\begin{array}{l}\text { panchromatic (PAN) } \\
\text { aerial photography }\end{array}$ & 1:20000 & $\begin{array}{c}\text { USACE - New Orleans } \\
\text { District }\end{array}$ \\
\hline $\begin{array}{l}\text { Sep. } 18 \text { and } \\
\text { Oct. } 17,1974\end{array}$ & $\begin{array}{l}\text { color infrared (CIR) } \\
\text { aerial photography }\end{array}$ & $\begin{array}{l}1: 119000 \\
1: 128000\end{array}$ & NASA JPL \\
\hline \multicolumn{4}{|c|}{ Landsat Thematic Mapper (TM) Imagery - Previously Classified } \\
\hline Nov. 1, 1990 & Landsat TM 5 & 28.5 meters & USGS \\
\hline Nov. 18, 1999 & Landsat ETM 7 & 28.5 meters & USGS \\
\hline Feb. 27, 2002 & Landsat ETM 7 & 28.5 meters & USGS \\
\hline \multicolumn{4}{|c|}{ Landsat Thematic Mapper (TM) Imagery - This Study } \\
\hline Jan. 6, 1983 & Landsat TM 4 & 28.5 meters & USGS \\
\hline Apr. 6, 1984 & Landsat TM 5 & 28.5 meters & USGS \\
\hline Sep. 29, 1984 & Landsat TM 5 & 28.5 meters & USGS \\
\hline Jan. 19, 1985 & Landsat TM 5 & 28.5 meters & USGS \\
\hline Oct. 8, 1987 & Landsat TM 5 & 28.5 meters & USGS \\
\hline Jan. 28, 1988 & Landsat TM 5 & 28.5 meters & USGS \\
\hline Oct. 11, 1991 & Landsat TM 5 & 28.5 meters & USGS \\
\hline Oct. 5, 1992 & Landsat TM 5 & 28.5 meters & USGS \\
\hline Jan. 25, 1993 & Landsat TM 5 & 28.5 meters & USGS \\
\hline Mar. 17, 1994 & Landsat TM 5 & 28.5 meters & USGS \\
\hline Nov. 15, 1995 & Landsat TM 5 & 28.5 meters & USGS \\
\hline Apr. 7, 1996 & Landsat TM 5 & 28.5 meters & USGS \\
\hline Oct. 3, 1997 & Landsat TM 5 & 28.5 meters & USGS \\
\hline Feb. 24, 1998 & Landsat TM 5 & 28.5 meters & USGS \\
\hline Jan. 26, 1999 & Landsat ETM 7 & 28.5 meters & USGS \\
\hline 0ct. 11, 2000 & Landsat TM 5 & 28.5 meters & USGS \\
\hline 0ct. 30, 2001 & Landsat TM 5 & 28.5 meters & USGS \\
\hline Dec. 28, 2002 & Landsat ETM 7 & 28.5 meters & USGS \\
\hline Oct. 20, 2003 & Landsat TM 5 & 28.5 meters & USGS \\
\hline Nov. 7, 2004 & Landsat TM 5 & 28.5 meters & USGS \\
\hline
\end{tabular}

Table 1. Source imagery used to analyze land-water changes in south-central Louisiana. 


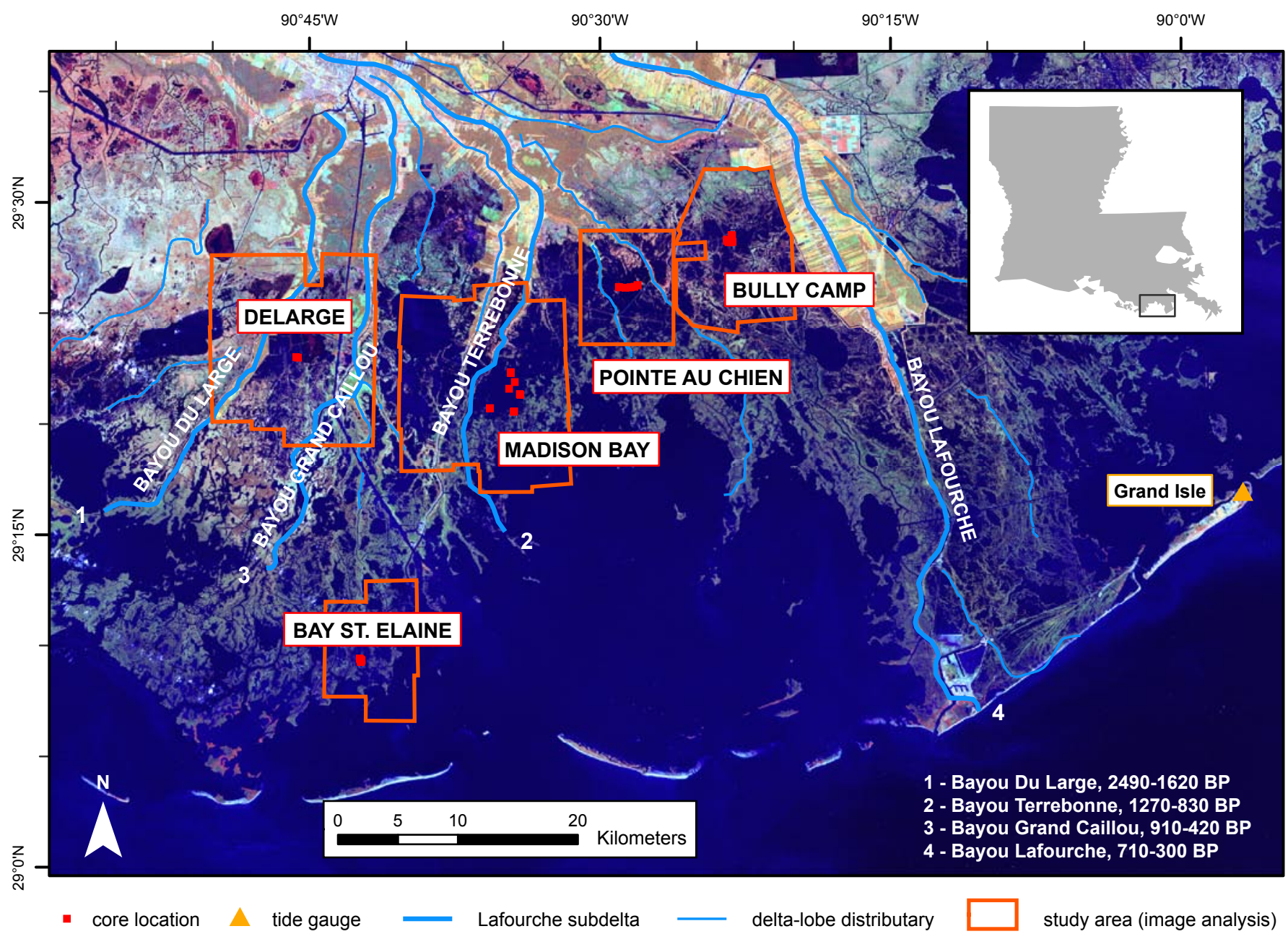

Figure 1. Regional map of south-central Louisiana showing locations of coring sites, boundaries of areas used for image analysis of land-water changes, and subdeltas of the Lafourche delta system. Geologic ages of the Lafourche subdeltas after Penland and others (1988). Landsat TM 5 image acquired Nov. 7, 2004. The RGB visual display uses bands 4 (near-infrared), 5 (mid-infrared), and 3 (visible red).

Marine Fisheries Service provided two additional periods to examine land-water changes before 1978.

\section{Aerial-Photograph Rectification and Land-Water Classification}

Both the PAN and CIR photographs were rectified and classified using the same methods. Individual frames were selected to include the coring locations at each site (Figs. 1 and 2) as well as to provide sufficient coverage of surrounding wetlands for trend analysis and interpretation. The PAN photography required from 6 to 18 frames to provide coverage of the study areas at a scale of 1:20,000. The smaller scale $(1: 119,000$ to $1: 128,000)$ CIR photographs generally required from one to three frames to provide coverage equivalent to the 1969 PAN photographs.
The source photographs were converted to a digital tif format by scanning each frame at 600 dots per inch (dpi). The PAN photographs were scanned as 8-bit grayscale images, whereas the CIR photographs were scanned as 24-bit color images. A polynomial rectification within ERDAS Imagine $8.6 \odot$ software was used to rectify individual digital frames to historic USGS DLG quadrangle maps and recent USGS digital orthophotographs of the sites. The individual frames were then merged into mosaics for the land-water classification of each study site. The maximum extent of the compared area for each site was controlled by the availability of 1969 PAN frames. In some cases, frames were missing, causing incomplete coverage of the sites (i.e., Bully Camp and DeLarge sites).

Land-water classifications for both the PAN and CIR photographs were created using Adobe Photoshop 7.0@ 


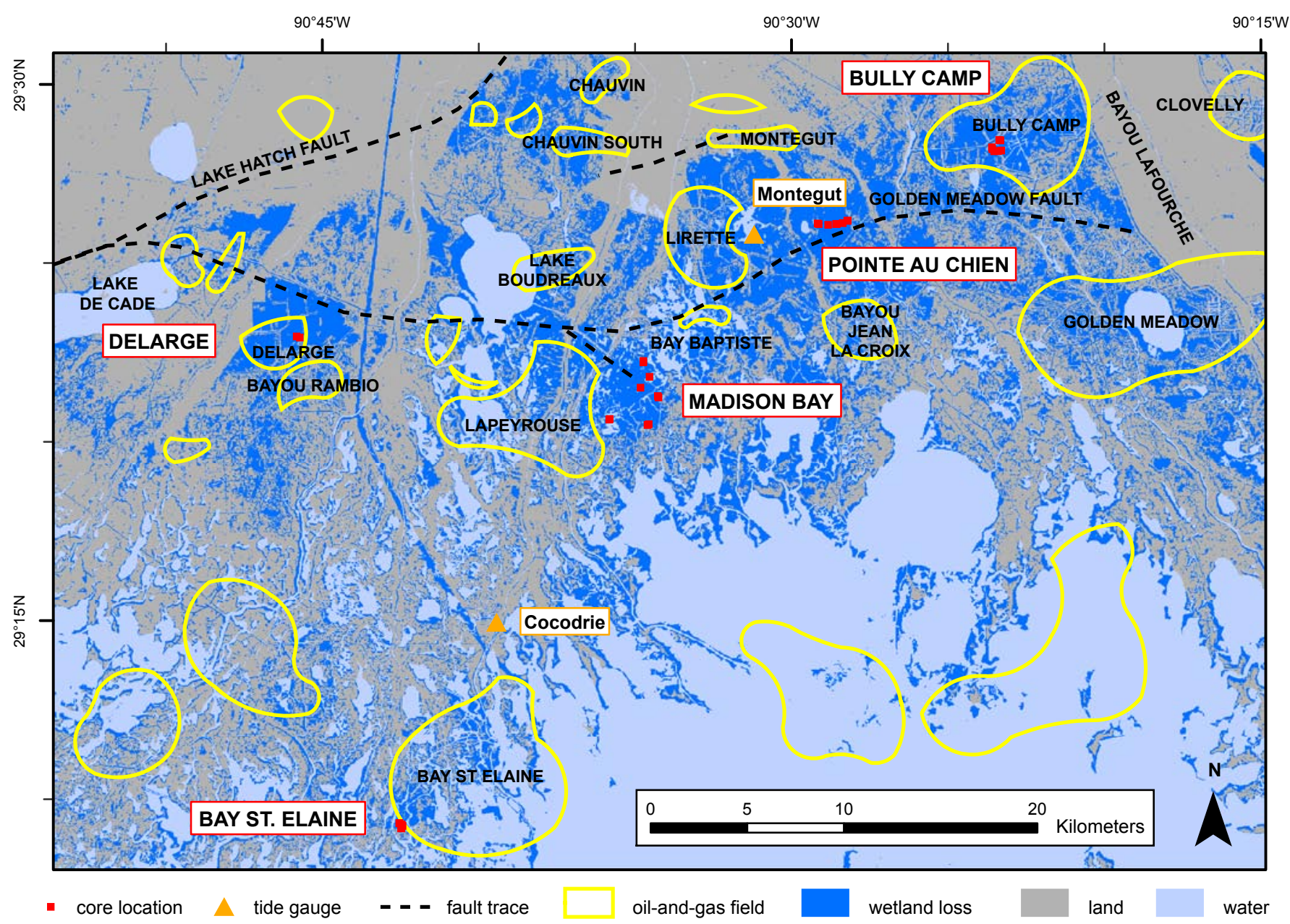

Figure 2. Regional map of south-central Louisiana showing locations of coring sites, the USACE Cocodrie tide gauge, the LDNR Montegut tide gauge, and the distribution of wetland losses (1956-2004) relative to producing oil-and-gas fields and potentially active faults. The Nov. 7, 2004 Landsat TM 5 image was used for the land-water classification. Fault projection from Kuecher and others (2001).

software. The rectified photomosaics for each site were converted to a Photoshop format. Photoshop Adjustment Layers were also used to enhance the visual identification of the land-water interface during the water classification. The individual land-water files were imported into Imagine and assigned projection information copied from the original rectified photomosaics. The land-water files were then resampled from source resolution to a $25 \times 25-\mathrm{m}$ pixel resolution to match the resolution of the Landsat TM and habitat landwater data sets.

\section{Landsat Thematic Mapper Land-Water Classification}

Landsat TM data consisted of cloud-free to nearly cloud-free TM 4, 5, and 7 scenes obtained between 1983 and 2004. All scenes were converted from radiance to reflectance values prior to land-water classification. The scenes were then classified applying the same methods used to develop the prior TM land-water data sets (Barras and others, 2003).

\section{Source Imagery Discussion}

Both the imagery and historic land-water data were acquired using different platforms with varied spatial resolutions and spectral characteristics. Although imagery characteristics differed, spatial resolution and positional accuracy of all source imagery were sufficient to document conversion of land to water throughout the study area on a consistent basis. The PAN and CIR photographs were prints that often needed to be enhanced to discern land-water classes in areas of poor contrast and sun flare. The higher 1x1-m spatial resolution of the PAN photography provided detailed land-water interface patterns not visibly evident in 
either the small-scale 1974 CIR photography or the satellite imagery. Conversely, the TM imagery provided better spectral discrimination of marsh wetness than either the PAN or CIR photography. The Landsat TM images were the most consistent source used to document land-water trends, although the spatial resolution is considered moderate at $28.5 \times 28.5 \mathrm{~m}$. All classified land-water datasets were resampled to a standard $25 \times 25 \mathrm{~m}$ to provide a consistent spatial resolution for assessing land-water area over time.

\section{Environmental Effects}

All images used to assess land-water trends were acquired after frontal passages under high-pressure systems with little to no cloud cover. Acquisition dates ranged from early fall through early spring. Land-water trends derived from the historic photographs (Fig. 3) were based on decadal or multidecadal comparisons due to the high cost of obtaining and interpreting coast-wide photography. The land-water datasets created for this study reflect conditions at the time of image acquisition. Flats and aquatic vegetation were classified as water if they could be easily identified on the source imagery.
The aerial photographs were often acquired over a period of several days due to weather conditions and acquisitionplatform capabilities. As a result, water level may have fluctuated between frames. These effects could not be assessed because accurate water levels and photographs bracketing known high- and low-water conditions were not available. Twenty-three TM data points, representing a 21-year period, provided a clearer interpretation of water-level effects on land-water classification and trend interpretation over annual and decadal time scales. Variations in water levels recorded at the National Ocean Service (NOS) Grand Isle, Louisiana tide gauge (NOS \#8761724) are clearly visible, and the shape of the classified water-area curve reflects this variability (Fig. 3). The dates with the greatest classified water area from the TM images corresponded to days with high-water conditions $(9 / 29 / 84,10 / 5 / 92$, and 10/20/03). Conversely, dates with the lowest classified water area corresponded to days with lowwater conditions $(4 / 6 / 84,1 / 28 / 88$, and 2/27/02). Water levels for the other image dates range between the high- and lowwater extremes.

\section{Composite water area, Louisiana delta plain, 1956-2004, vs. Grand Isle, Louisiana (NOS \#8761724) water levels for Landsat TM image-acquisition dates, 1983-2004}

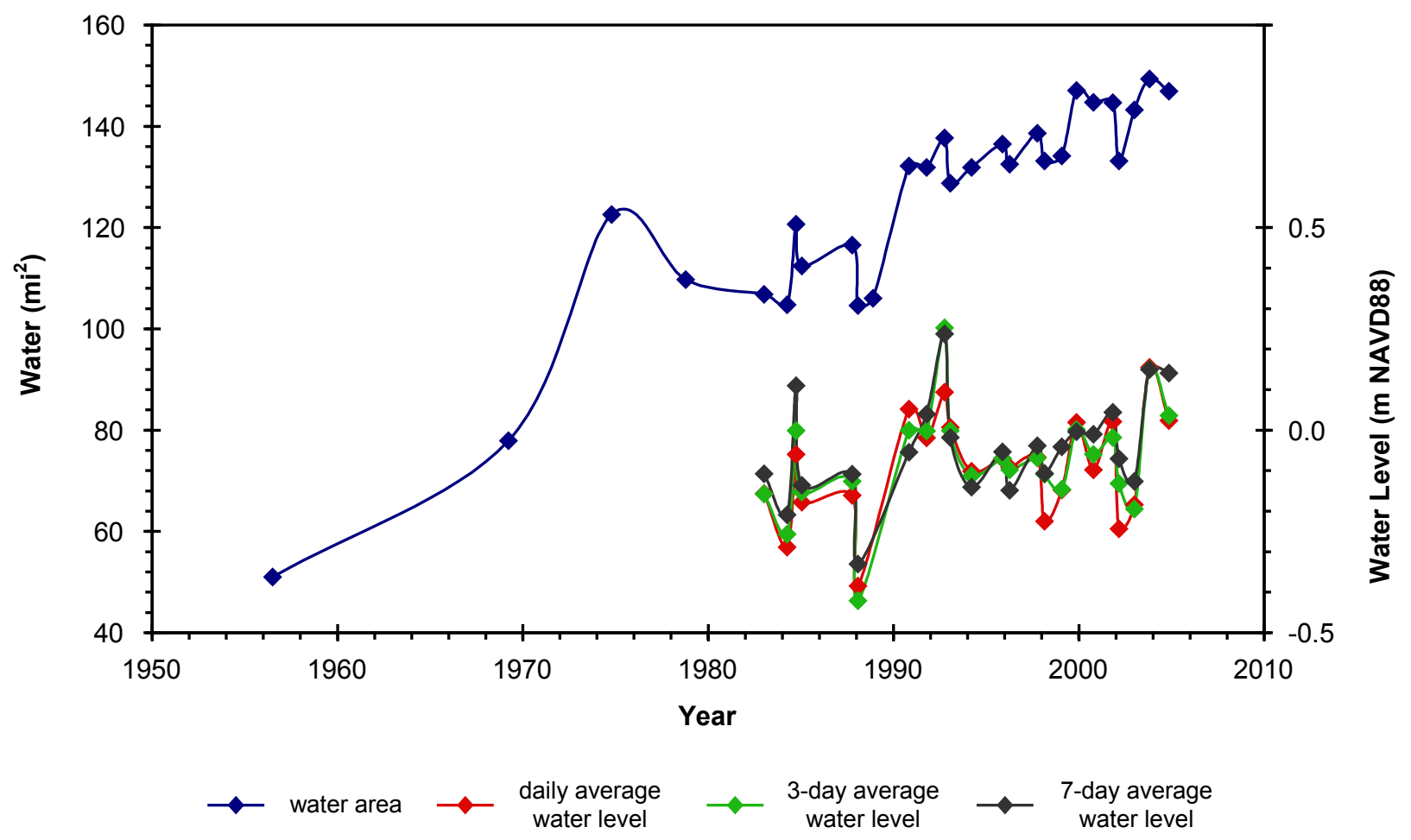

Figure 3. Composite historical land-water changes between 1956 and 2004 for the selected study areas in southcentral Louisiana, with daily, 3-day, and 7-day average water levels recorded at the NOS Grand Isle tide gauge for the corresponding Landsat TM image-acquisition dates between 1983 and 2004. 


\section{Trend Statistics}

A thematic raster data set was created containing the minimum shared area for each study site encompassed by all land-water datasets from 1956 - 2004. The Imagine SUMMARY function was used to compare each individual raster site file to each land-water file to produce land-water acreage summaries for each site. Aggregate land-water acreage summaries (Fig. 3) were created for all of the sites utilizing the same methods.

\section{Field and Laboratory Procedures}

Fieldwork conducted from June 25-27, 2003 and September 2-4, 2003 involved collecting vibracores and measuring water depths at the Bay St. Elaine, DeLarge, Pointe au Chien, and Bully Camp areas (Figs. 1 and 2). Twenty-two vibracores and two push-cores were located with a portable GPS receiver within these areas where historical wetland loss has been rapid and widespread. Pairs of cores taken across the perimeter of the wetland-loss hotspots provided close correlation between delta-plain sediments from the emergent marsh and adjacent open water. Ten other vibracores had previously been collected from the Madison Bay area (Figs. 1 and 2), and the procedures established for analyzing and interpreting those cores (Morton and others, 2003) were applied to the cores collected from the other four areas. The cores were transported to the USGS Center for Coastal and Watershed Studies at St. Petersburg, Florida. Each core was cut into 1-m sections, and each section was split lengthwise. One half of each core was cleaned, photographed, and described in detail, and all core sections were then placed in containers and stored. The core descriptions and photographs (Appendix 1) provided a basis for identifying the predominant sedimentary facies and for selecting stratigraphic contacts and surfaces that could be correlated between cores and used to estimate magnitudes of wetland subsidence and erosion (Table 2).

\section{Water-Level Measurements and Corrections}

Water depths at open-water coring sites and along bathymetric profiles were measured from the coring barge with a graduated rod, while the geographic coordinates of each depth measurement were obtained simultaneously with a GPS receiver. Movements of water levels at the coring sites during the field operations were assumed to be comparable to those recorded at nearby tide gauges (Fig. 2 and Morton and others, 2003).

Water depths and marsh elevations measured in the field (Table 2) can be compared only if they are corrected for any local conditions (e.g., tidal stage) that would bias the waterlevel data. The USACE New Orleans District and Louisiana
Department of Natural Resources (LDNR) operate independent networks of tide gauges located throughout the coastal waters of south Louisiana. The tide gauges at Cocodrie (USACE \#76305) and near Montegut (LDNR \#TE01-12R) are located less than $20 \mathrm{~km}$ from the coring sites (Fig. 2). Using electronic tide-gauge data from the USACE and LDNR websites, primary water levels for the dates and times of data collection were plotted (Fig. 4) relative to the North American Vertical Datum of 1988 (NAVD88). The Cocodrie tide gauge was used to correct measured water levels at Bay St. Elaine, Madison Bay, and DeLarge, and the Montegut tide gauge was used to correct measured water levels at Pointe au Chien and Bully Camp.

\section{Core Deformation}

At most vibracoring sites, the core barrel penetrates deeper than the length of sediment that is recovered in the core barrel. The difference between core depth and recovered core length is typically greatest when the bottom of the core barrel is plugged with stiff mud. The difference between penetration and recovery is commonly reported as sediment compaction (Appendix 1), although a more accurate definition of the difference is core shortening (Morton and White, 1997). Core shortening is estimated in the field by measuring how far the sediment in the core barrel is below the adjacent sediment surface. After the core is opened, the stratigraphic intervals that are influenced by core shortening can be determined visually by identifying the zones of sediment disturbance (see core photographs in Appendix 1). The degree of sediment deformation can be determined by comparing the stratigraphic contacts and laminae with actual or inferred horizontal planes across the core. The horizontal planes represent the expected configuration of undisturbed sediments. Some zones of disturbed sediments are also apparent because they occur between zones of undisturbed sediments (Appendix 1, core SM-05, approx. 230-340 cm). Criteria for recognizing the zones of sediment disturbance and core shortening include bending of stratigraphic contacts as a result of frictional drag along the core barrel (Appendix 1, core MB-07, multiple contacts approx. $165-195 \mathrm{~cm}$ ) and contortion of sediment laminae (Appendix 1, core PAC-01B, approx. 300-600 cm). In many of the cores, the zone of greatest sediment disturbance is below the organic-rich sediments (marsh peats) and typically below the contact between the firm massive mud with relatively low water content and the underlying muddy or silty sand with relatively high water content (Fig. 5). The frictional resistance of the firm mud causes liquifaction of the silty sand, and core bypassing results as the firm mud pushes some of the liquefied sand aside. Consequently, the entire sandy section is not recovered in the core barrel.

Specific coring techniques, such as limiting initial penetration rates of the core barrel, can be used to minimize compaction of the surficial organic-rich section. Despite efforts 
to minimize compaction, some emergent marsh sediments may be compacted enough that it could influence the magnitudes of subsidence estimated from stratigraphic correlation of core pairs. Because imprecision may be introduced by core shortening, results of the stratigraphic comparisons should be viewed as providing approximate magnitudes of subsidence and erosion, and a way of determining the relative significance of the two processes in converting former wetlands to open water.

\begin{tabular}{|c|c|c|c|c|c|c|}
\hline \multirow[b]{2}{*}{ Core ID } & \multirow[b]{2}{*}{ Core location } & \multirow[b]{2}{*}{$\begin{array}{l}\text { Core Elevation } \\
\text { (cm NAVD88) }\end{array}$} & \multicolumn{2}{|c|}{ Base Last Marsh } & \multicolumn{2}{|c|}{ Base First Marsh } \\
\hline & & & $\begin{array}{c}\text { Depth in Core Barrel } \\
(\mathbf{c m})\end{array}$ & $\begin{array}{c}\text { Elevation } \\
\text { (cm NAVD88) }\end{array}$ & $\begin{array}{c}\text { Depth in Core Barrel } \\
(\mathrm{cm})\end{array}$ & $\begin{array}{c}\text { Elevation } \\
\text { (cm NAVD88) }\end{array}$ \\
\hline \multicolumn{7}{|c|}{ Bay St. Elaine Area } \\
\hline composite BSE-04 & marsh & 49 & & & 105 & -56 \\
\hline BSE-05 & water & -7 & & & 112 & -119 \\
\hline difference (M-W) & & 56 & & & -7 & 63 \\
\hline composite BSE-04 & marsh & 49 & & & 105 & -56 \\
\hline BSE-01 & water & -35 & & & 150 & -185 \\
\hline difference (M-W) & & 84 & & & -45 & 129 \\
\hline BSE-01 & water & -35 & & & 150 & -185 \\
\hline composite BSE-03 & marsh & 50 & & & 96 & -46 \\
\hline difference (M-W) & & 85 & & & -54 & 139 \\
\hline BSE-02 & water & -8 & & & 111 & -119 \\
\hline composite BSE-03 & marsh & 50 & & & 96 & -46 \\
\hline difference (M-W) & & 58 & & & -15 & 73 \\
\hline \multicolumn{7}{|c|}{ Madison Bay Area } \\
\hline MB-10 & marsh & 30 & 153 & -123 & 198 & -168 \\
\hline MB-06 & water & -58 & 129 & -187 & 175 & -233 \\
\hline difference $(M-W)$ & & 88 & 24 & 64 & 23 & 65 \\
\hline MB-10 & marsh & 30 & 153 & -123 & 198 & -168 \\
\hline MB-05 & water & -92 & 111 & -203 & 134 & -226 \\
\hline difference (M-W) & & 122 & 42 & 80 & 64 & 58 \\
\hline MB-10 & marsh & 30 & 153 & -123 & 198 & -168 \\
\hline MB-04 & water & -108 & 90 & -198 & 134 & -242 \\
\hline difference (M-W) & & 138 & 63 & 75 & 64 & 74 \\
\hline MB-01 & water & -46 & 125 & -171 & 186 & -232 \\
\hline MB-07 & marsh & 24 & 115 & -91 & 192 & -168 \\
\hline difference (M-W) & & 70 & -10 & 80 & 6 & 64 \\
\hline MB-05 & water & -92 & 111 & -203 & 134 & -226 \\
\hline MB-09 & marsh & 17 & 146 & -129 & 168 & -151 \\
\hline difference (M-W) & & 109 & 35 & 74 & 34 & 75 \\
\hline MB-03 & water & -77 & 118 & -195 & 131 & -208 \\
\hline MB-09 & marsh & 17 & 146 & -129 & 168 & -151 \\
\hline difference (M-W) & & 94 & 28 & 66 & 37 & 57 \\
\hline MB-02 & water & -59 & 134 & -193 & 151 & -210 \\
\hline MB-08 & marsh & 20 & 161 & -141 & 180 & -160 \\
\hline difference (M-W) & & 79 & 27 & 52 & 29 & 50 \\
\hline \multicolumn{7}{|c|}{ DeLarge Area } \\
\hline DL-01B & marsh & 32 & 30 & 2 & 110 & -78 \\
\hline DL-01A & water & -49 & 28 & -77 & 97 & -146 \\
\hline difference (M-W) & & 81 & 2 & 79 & 13 & 68 \\
\hline \multicolumn{7}{|c|}{ Pointe au Chien Area } \\
\hline PAC-05 & marsh & 33 & 41 & -8 & & \\
\hline PAC-04 & water & -41 & 42 & -83 & & \\
\hline difference (M-W) & & 74 & -1 & 75 & & \\
\hline PAC-05 & marsh & 33 & 41 & -8 & & \\
\hline PAC-06 & water & -54 & 33 & -87 & & \\
\hline difference (M-W) & & 87 & 8 & 79 & & \\
\hline
\end{tabular}

Table 2. Core depths and NAVD88 elevations of stratigraphic markers correlated between cores. The most prominent markers are contacts between predominantly organic and predominantly clastic sediments. Positive marsh-minus-water (M-W) depth-difference values indicate erosion, and negative $M-W$ depth-difference values indicated sediment accumulation. M-W elevation-difference values represent estimated subsidence. Cores are arranged in the same order that they are shown on the stratigraphic cross-sections (Figs. 7, $9,10,12,14$, and 16$)$. 


\begin{tabular}{|c|c|c|c|c|c|c|}
\hline \multirow[b]{2}{*}{ Core ID } & \multirow[b]{2}{*}{ Core location } & \multirow[b]{2}{*}{$\begin{array}{l}\text { Core Elevation } \\
\text { (cm NAVD88) }\end{array}$} & \multicolumn{2}{|c|}{ Base Last Marsh } & \multicolumn{2}{|c|}{ Base First Marsh } \\
\hline & & & $\begin{array}{l}\text { Depth in Core Barrel } \\
(\mathrm{cm})\end{array}$ & $\begin{array}{c}\text { Elevation } \\
\text { (cm NAVD88) }\end{array}$ & $\begin{array}{l}\text { Depth in Core Barrel } \\
(\mathrm{cm})\end{array}$ & $\begin{array}{l}\text { Elevation } \\
\text { (cm NAVD88) }\end{array}$ \\
\hline PAC-05 & marsh & 33 & 41 & -8 & & \\
\hline PAC-02A & water & -41 & 46 & -87 & & \\
\hline difference (M-W) & & 74 & -5 & 79 & & \\
\hline PAC03-05 & marsh & 33 & 41 & -8 & & \\
\hline PAC03-02B & marsh & 32 & 56 & -24 & & \\
\hline difference (05-02B) & & 1 & -15 & 16 & & \\
\hline PAC-02A & water & -41 & 46 & -87 & 114 & -155 \\
\hline PAC-02B & marsh & 32 & 56 & -24 & 99 & -67 \\
\hline difference (M-W) & & 73 & 10 & 63 & -15 & 88 \\
\hline PAC-02B & marsh & 32 & 56 & -24 & 99 & -67 \\
\hline PAC-03 & water & -62 & 42 & -104 & 129 & -191 \\
\hline difference (M-W) & & 94 & 14 & 80 & -30 & 124 \\
\hline PAC03-02B & marsh & 32 & 56 & -24 & 99 & -67 \\
\hline PAC03-01B & marsh & 39 & 26 & 13 & 103 & -64 \\
\hline difference (01B-02B) & & 7 & -30 & 37 & 4 & 3 \\
\hline PAC-03 & water & -62 & 42 & -104 & 129 & -191 \\
\hline PAC-01B & marsh & 39 & 26 & 13 & 103 & -64 \\
\hline difference (M-W) & & 101 & -16 & 117 & -26 & 127 \\
\hline PAC-01A & water & -38 & 39 & -77 & 110 & -148 \\
\hline PAC-01B & marsh & 39 & 26 & 13 & 103 & -64 \\
\hline difference (M-W) & & 77 & -13 & 90 & -7 & 84 \\
\hline & & & Bully Camp Area & & & \\
\hline SM-02B & marsh & 49 & 59 & -10 & 93 & -44 \\
\hline SM-02A & water & -45 & 33 & -78 & 80 & -125 \\
\hline difference (M-W) & & 94 & 26 & 68 & 13 & 81 \\
\hline SM-02B & marsh & 49 & 59 & -10 & 93 & -44 \\
\hline SM-05 & water & -50 & 56 & -106 & 92 & -142 \\
\hline difference (M-W) & & 99 & 3 & 96 & 1 & 98 \\
\hline SM-02B & marsh & 49 & 59 & -10 & 93 & -44 \\
\hline SM-03 & marsh & -8 & 61 & -69 & 103 & -111 \\
\hline difference (02B-03) & & 57 & -2 & 59 & -10 & 67 \\
\hline SM-02B & marsh & 49 & 59 & -10 & 93 & -44 \\
\hline SM-04 & water & $-135^{*}$ & $24^{*}$ & -159 & $51^{*}$ & -186 \\
\hline difference (M-W) & & 184 & 35 & 149 & 42 & 142 \\
\hline SM-04 & water & -135 & $24^{*}$ & -159 & & \\
\hline SM-01B & marsh & $28^{* *}$ & $46^{* *}$ & -18 & & \\
\hline difference (M-W) & & 163 & 22 & 141 & & \\
\hline SM-01A & water & -67 & 40 & -107 & & \\
\hline SM-01B & marsh & $28^{* *}$ & $46^{* *}$ & -18 & & \\
\hline difference (M-W) & & 95 & 6 & 89 & & \\
\hline
\end{tabular}

Table 2 continued.

\section{Isotopic Analyses}

Peat samples from the vibracores were submitted to Beta Analytic, Inc. (Miami, Florida) for isotopic analysis of the organic material. The laboratory provided radiocarbon ages $\left({ }^{14} \mathrm{C}\right)$ and the corresponding $\delta^{13} \mathrm{C}$ values for the remains of former delta-plain marshes (Table 3). Chmura and others (1987) conducted a statistical analysis of $\delta^{13} \mathrm{C}$ ratios for extant plants comprising the fresh, intermediate, brackish, and saline marshes of the Barataria Basin. The ranges and means of $\delta^{13} \mathrm{C}$ ratios for these marshes (Table 4) were used to interpret the types of marshes preserved in the vibracores because the
Terrebonne-Lafourche study area is close to the Barataria Basin and similar in geologic setting.

Average long-term geological rates of delta-plain subsidence can be inferred from burial histories of peats, using the peat depths below the surface and the ${ }^{14} \mathrm{C}$ peat ages (Penland and others, 1988; Roberts and others, 1994; Kulp and Howell, 1998). Results of those calculations (Tables 5 and 6) can also be expressed as average long-term geological rates of sediment aggradation. For this report, burial histories of peats are expressed as subsidence rates rather than rates of sediment aggradation. For cores with more than 
one dated peat, two different inferred subsidence rates can be calculated using the same data. Taking the peat depth and dividing by its age gives the simplest estimate. This calculation yields an average rate of subsidence for the entire sedimentary section above the peat. A more precise method recognizes that different rates of subsidence can occur at different times. For the second method, the difference in depths and difference in peat ages at the top and bottom of an interval are used to calculate the subsidence rate of the interval. This method of differences restricts the averaging to only the interval of interest. Where possible, subsidence rates for both depth and interval methods were calculated (Table 5).

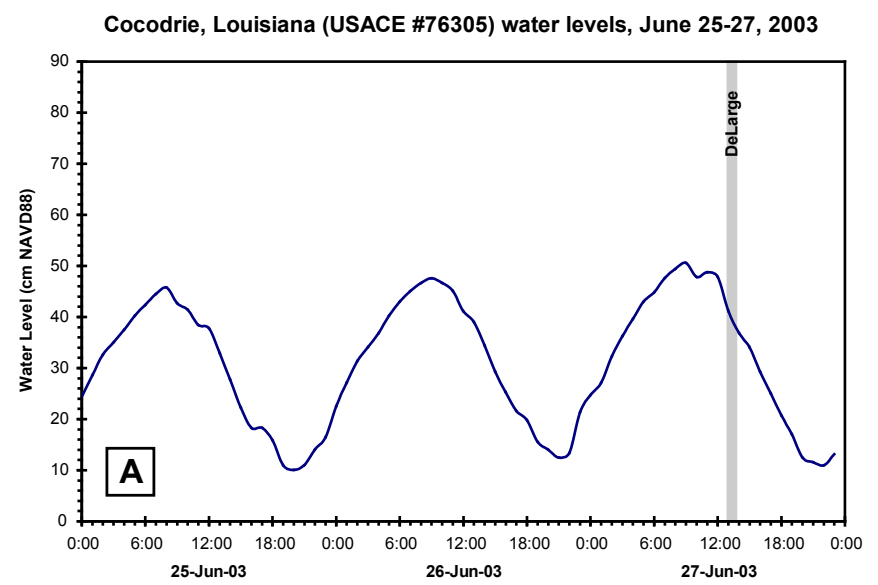

Montegut, Louisiana (LDNR \#TE01-12R) water levels, June 25-27, 2003

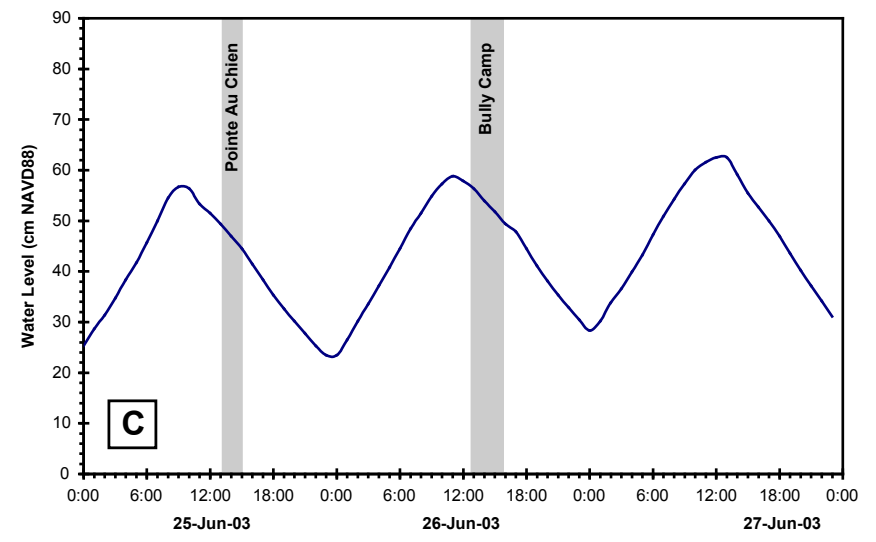

\section{Historical Land-Water Changes}

\section{Analytical Methods}

Historical land-water changes are assessed by mapping the distribution of land and water for specific dates and then comparing changes in land-water location and area between the dates. Average annual rates of change are derived for each period by dividing the total change in water area or land area by the number of years between observations. Although landloss rates for discrete periods probably are not linear, average annual land-loss rates, based on historical trends, are important for assessing the feasibility of wetland-restoration projects in coastal Louisiana.

Land-water conditions at the time of image acquisition are assumed to be representative of normal or average conditions, regardless of water-level variation, other environmental

Cocodrie, Louisiana (USACE \#76305) water levels, September 2-4, 2003

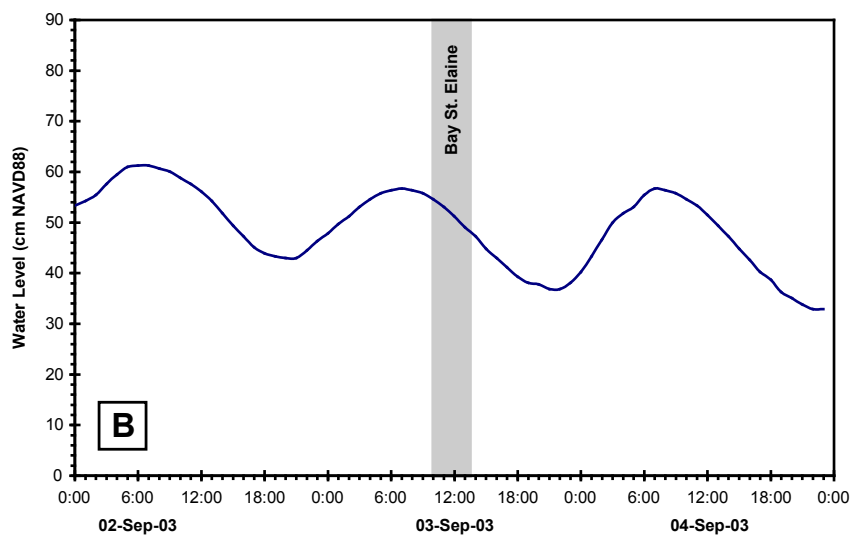

Montegut, Louisiana (LDNR \#TE01-12R) water levels, September 2-4, 2003

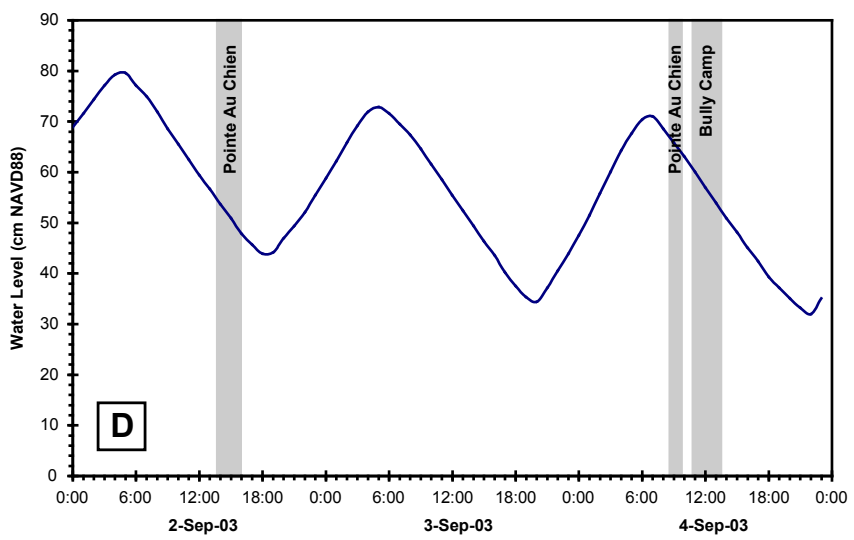

Figure 4. Water levels recorded at the Cocodrie tide gauge on (A) June 25-27 and (B) September 2-4, 2003, and at the LDNR Montegut tide gauge on (C) June 25-27 and (D) September 2-4, 2003. Phases of the tides during field operations are highlighted (in grey). Gauge locations are shown in Figure 2. 
conditions, or water-management influences. It is also assumed that there are no major differences in classification methods that might increase or decrease interpreted land or water area. Providing a clearer understanding of the timing and spatial patterns of historic land loss requires interpreting aerial photography acquired between 1956 and 1978, when the habitat data were generated. Determining present average land-water area and current land-loss rates based on multiple short-term data points requires developing classification methods that recognize variance in land-water area caused by environmental factors and human modifications. One approach to obtaining recent trend estimates is to acquire and classify multiple images separated by short periods using a standard acquisition platform. Ranges and averages of land-water area can be calculated and compared over time, providing a more reliable trend estimate. Continuous increases in water area over time indicate continued land loss, regardless of image acquisition conditions.

These methods enable quantification of land-water changes and visual depiction of resultant spatial trends, but interpretation of land-water data and trends also requires examination and comparison of source photography and satellite imagery at regional and local scales. The coring sites focus on local areas within or adjacent to land-loss hotspots. The timing and patterns of regional land loss provide insight into how local land-loss histories fit into the overall patterns of land loss.

\section{Regional Land-Water Changes 1956-2004}

The initial regional-trend investigation focused on visually comparing Landsat TM imagery for the entire 180x $185-\mathrm{km}$ scene from 1983 to 2004 using a RGB visual display combination of TM spectral bands 4 (near-infrared), 5 (mid-infrared), and 3 (visible red). The band combination is used to discriminate between water, wet marsh, and marsh areas. Wet marsh is a category for land that appears wetter than surrounding marsh due to absorption of mid-infrared and near-infrared wavelengths, but has a higher spectral reflectance of the infrared bands than water. Wet marsh is usually located adjacent to ponds and in marsh that is fragmenting into complex interlaced networks of marsh and water. The extent of wet marsh varies depending on water level, marsh elevation, spectral-reflectance variations linked to the seasonal marsh-vegetation growth cycle, and density of vegetative cover. Persistent wet marshes tend to be located next to former land-loss hotspots. Identification of persistent wet marsh over multiple periods was used to locate post-1983 land-loss hotspots developing within the scene.

Comparison of current hotspot formation can be used as an analogue to historic hotspot formation. The visual review of the TM data revealed that: (1) new land-loss hotspots developed between 1983 and 2004 but were not as large or as numerous as those that formed between 1956 and 1978, (2) land-loss hotspot formation was more noticeable between the mid-1980s to 1990, (3) areas of wet marsh within and adjacent to former hotspots converted to water between 1983 and 2004, (4) effects of water-level variation were apparent over short periods, (5) wet marsh is present in contiguous marsh, but it generally does not convert to open water over time, and (6) the surface expression of apparent faults could be observed as linear features separating wet marsh from marsh. The 1978 and mid-1980s landscapes were similar, indicating that rapid historic land loss occurred before 1978. The information gained from interpreting multiple dates of TM imagery between 1983 and 2004 indicated that a similar examination of pre-1983 aerial photography would provide additional information to refine temporal trends and spatial patterns.

In addition to the 1968-1969 PAN and 1974 CIR photographs, other aerial photographs were examined for the interval between 1956 and 1978. Agricultural Commodity Service (ACS) photo-indexes and selected frames for 1940, 1953, and 1957 were used to determine mid-century landscape conditions. The original 1978 CIR photography used to develop the 1978 habitat land-water dataset also was

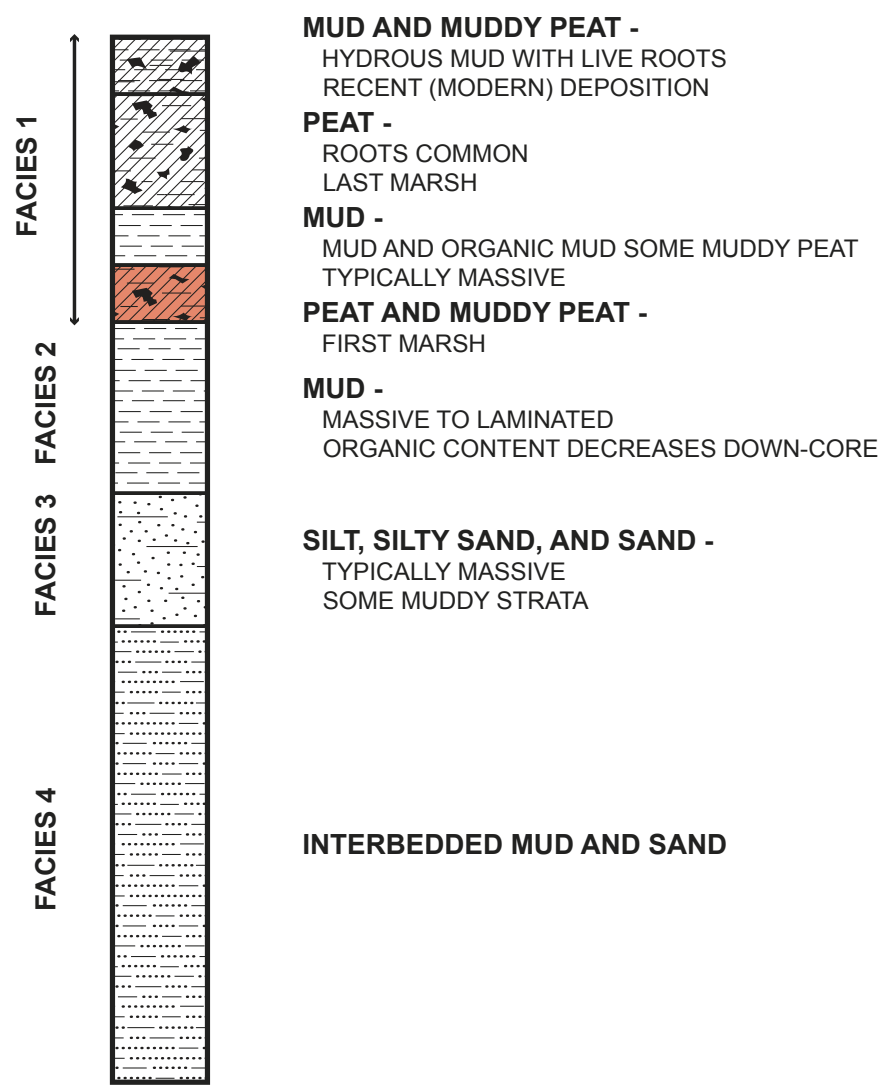

Figure 5. Generalized core profile showing the stratigraphic position of shallow deltaic sediments of the Lafourche subdelta. 


\begin{tabular}{|c|c|c|c|c|}
\hline Core ID & Sample Depth (cm) & Stratigraphic Horizon & Conventional Age (BP) & d13C $(\%)$ \\
\hline \multicolumn{5}{|c|}{ Bay St. Elaine Area } \\
\hline BSE-01 & $146-147$ & base first marsh & $820 \pm 40$ & -25.6 \\
\hline BSE-02 & $73-74$ & top first marsh & $400 \pm 40$ & -23.4 \\
\hline BSE-02 & $110-111$ & base first marsh & $850 \pm 40$ & -26.6 \\
\hline BSE-04 & $21-22$ & top first marsh & $320 \pm 40$ & -24.6 \\
\hline BSE-04 & $71-72$ & base first marsh & $680 \pm 40$ & -24.8 \\
\hline BSE-05 & $37-38$ & base last marsh & $200 \pm 40$ & -13.9 \\
\hline \multicolumn{5}{|c|}{ Madison Bay Area } \\
\hline MB-02 & $133-134$ & base last marsh & $840 \pm 40$ & -26.0 \\
\hline MB-02 & $145-146$ & top first marsh & $940 \pm 40$ & -25.6 \\
\hline MB-02 & $150-151$ & base first marsh & $930 \pm 40$ & -25.8 \\
\hline MB-04 & 107-108 & top intermediate marsh & $720 \pm 40$ & -26.6 \\
\hline MB-04 & $113-114$ & base intermediate marsh & $700 \pm 40$ & -27.0 \\
\hline MB-04 & $133-134$ & base first marsh & $960 \pm 40$ & -26.7 \\
\hline MB-07 & $114-115$ & base last marsh & $600 \pm 40$ & -25.8 \\
\hline MB-07 & $186-187$ & top first marsh & $980 \pm 40$ & -26.3 \\
\hline MB-07 & $191-192$ & base first marsh & $950 \pm 40$ & -26.5 \\
\hline MB-09 & $46-47$ & base recent marsh & $150 \pm 40$ & -14.1 \\
\hline MB-09 & $145-146$ & base last marsh & $680 \pm 40$ & -26.7 \\
\hline MB-09 & $167-168$ & base first marsh & $920 \pm 40$ & -26.3 \\
\hline MB-10 & $152-153$ & base last marsh & $660 \pm 40$ & -26.4 \\
\hline MB-10 & $197-198$ & base first marsh & $970 \pm 40$ & -26.5 \\
\hline \multicolumn{5}{|c|}{ DeLarge Area } \\
\hline DL-01A & $26-27$ & base last marsh & $510 \pm 40$ & -27.4 \\
\hline DL-01A & $56-57$ & top first marsh & $840 \pm 40$ & -26.4 \\
\hline DL-01A & $95-96$ & base first marsh & $1050 \pm 40$ & -26.9 \\
\hline \multicolumn{5}{|c|}{ Pointe au Chien Area } \\
\hline PAC-01A & $109-110$ & base first marsh & $900 \pm 40$ & -27.2 \\
\hline PAC-01B & $25-26$ & base last marsh & $280 \pm 40$ & -26.1 \\
\hline PAC-02A & $91-92$ & top first marsh & $930 \pm 40$ & -27.3 \\
\hline PAC-02A & $112-113$ & base first marsh & $980 \pm 40$ & -28.0 \\
\hline PAC-02B & $55-56$ & base last marsh & $430 \pm 40$ & -26.2 \\
\hline PAC-03 & $99-100$ & first marsh & $940 \pm 40$ & -27.4 \\
\hline PAC-03 & $128-129$ & base first marsh & $950 \pm 40$ & -19.4 \\
\hline \multicolumn{5}{|c|}{ Bully Camp Area } \\
\hline SM-01B & $27-28$ & base recent marsh & $90 \pm 40$ & -26.3 \\
\hline SM-01B & $72-73$ & base last marsh & $420 \pm 40$ & -27.4 \\
\hline SM-02B & $58-59$ & base last marsh & $450 \pm 40$ & -26.5 \\
\hline SM-02B & $85-86$ & top first marsh & $860 \pm 50$ & -27.0 \\
\hline SM-02B & $92-93$ & base first marsh & $900 \pm 40$ & -27.3 \\
\hline
\end{tabular}

Table 3. Radiocarbon ages and carbon-isotope data for organic samples. 


\begin{tabular}{ccc} 
Marsh Type & Range $(\%)$ & Mean $(\%)$ \\
\hline Fresh & $27.4-28.4$ & 27.8 \\
Intermediate & $18.4-25.0$ & 22.1 \\
Brackish & $15.3-20.4$ & 16.9 \\
Saline & $14.4-17.7$ & 16.2
\end{tabular}

Table 4. Ranges and means of $\delta^{13} \mathrm{C}$ measured in plants from marshes in Barataria Basin, Louisiana (Chmura and others, 1987).

reviewed. The visual review of photography showed the following conditions. In 1940, 1953, and 1957, the landscape was unbroken interior marsh between swamp and distributary ridges, the interior marsh was bordered on the south by estuarine marshes, and the 1953 and 1957 landscape closely resembled the 1956 land-water conditions. Marsh-surface fragmentation, small pond formation, and submerged marsh were apparent within hotspot areas by 1968-1969 but were limited in size. Large historic land-loss hotspots, widespread marsh fragmentation, pond formation, and large areas of submerged marsh were well defined by 1974. The 1974 landscape more closely resembled the mid-1980s landscape than it did the 1968-69 landscape. Comparison of the 1974 CIR and 1978 CIR photography also showed that the land-loss hotspots were persistent. Some areas identified as water in 1974 were exposed as marsh in 1978, indicating that waterlevel fluctuations effected land-loss interpretations. Areas that were identified as water in 1974 and land in 1978 converted to water by the late 1980s and early 1990s, often after repeated exposure/submergence events. The historic hotspots required less time to convert to open water than did the post-1983 hotspots (5+ years vs. $15+$ years).

When viewed together, the historical photographs and satellite images show a pattern of initial accelerating land loss by the late 1960s, and the rapid acceleration of land loss and development of large hotspots with associated submerged marsh by the early 1970s. The late 1970s through early 1990s were characterized by continued marsh loss, primarily caused by the submergence of wet-marsh areas. The 1990s to the present exhibit complete submergence of former wet-marsh areas within and immediately adjacent to land-loss hotspots. Remnant high-marsh islands, natural levees, and spoil mounds are the only remaining exposed land. Areas of wet marsh in non-contiguous marshes outside of hotspots exhibit a tendency to convert to open water over time, following the familiar pattern of exposure, submergence, exposure, and then conversion to open water observed in the imagery review.

Analysis of land-water changes for all study sites (Table 7) and the derived curve (Fig. 3) corroborate the visual interpretation of a rapid increase in land loss in the late 1960s and early 1970s followed by a decreased loss rate from the 1980 s to present. The total water area varies by as much as $\pm 5 \%$ over short periods, indicating that the classification was effected by external factors such as water-level fluctuations. Total water area increased about 25\% from 1956 to 1974 as compared to a 9\% area increase from 1974 to 2004.

\section{Sediment Types and Depositional History}

\section{Sediment Descriptions}

Most vibracores recovered a succession of unconsolidated sediments representing four general sedimentary facies (Fig. 5). For delta-plain sediments unaffected by recent rapid subsidence, the common facies, from youngest to oldest, are: (1) peat and interbedded mud, (2) mud, (3) sand and silty sand, and (4) interbedded mud and sand. At some coring sites, thin deposits of mud or sand are found at the top of the core, above the well-developed peat. These commonly muddy sediments represent recent deposition as a result of natural marsh processes, sediment redistribution associated with nearby pipeline construction and canal dredging, or a response to accelerated subsidence and marsh submergence.

The modern marsh sediments consist of water-saturated gray or brown mud interspersed with large fibrous roots that are associated with living Spartina sp. marsh plants. The "live" roots and saturated mud indicate recent accumulation of both organic and clastic sediments. Below the most recent (modern) marsh deposits are black peat deposits with abundant fibrous roots that contain some dispersed mud. In most of the cores, the peat and organic-rich sediments are in gradational contact with, or alternate with, thin beds of mud that contain roots or root traces. The organic content of the sediments was estimated visually, not using an analytical technique such as loss-onignition.

The second sedimentary facies is dark-gray to olivegray mud that typically contains abundant root traces. The abundances of root traces and total organic content decrease with depth. The overall massive appearance of this facies is likely the result of extensive bioturbation. The massive mud grades downward into the underlying sand and silty sand facies.

The next facies consists of light olive-gray very finegrained sand, silty sand, or silt that is commonly massive but may be interlaminated with mud. The sandy sediments do not contain roots, although they may contain rare shell fragments. This facies commonly shows the most sediment deformation. The sand and silty sand facies may be in sharp or gradational contact with the underlying alternating sand and mud facies. Predominantly clean sand is present only at the Bay St. Elaine and Madison Bay coring sites. 


\begin{tabular}{|c|c|c|c|c|c|c|}
\hline $\begin{array}{l}\text { Core ID and Sample } \\
\text { Depth }(\mathrm{cm})\end{array}$ & Stratigraphic Horizon & ${ }^{14} \mathrm{C}$ Age (BP) & $\begin{array}{c}\text { Marsh } \\
\text { Thickness (cm) }\end{array}$ & $\begin{array}{c}\text { Interval Rate } \\
(\mathrm{mm} / \mathrm{yr})\end{array}$ & $\begin{array}{l}\text { Sample Depth } \\
\text { (cm) }\end{array}$ & $\begin{array}{c}\text { Depth Rate } \\
\text { (mm/yr) }\end{array}$ \\
\hline \multicolumn{7}{|c|}{ Bay St. Elaine Area } \\
\hline BSE-01-146/147 & base first marsh & 820 & & & 147 & 1.8 \\
\hline BSE-02-073/074 & top first marsh & 400 & 38 & 0.8 & 74 & 1.9 \\
\hline BSE-02-110/111 & base first marsh & 850 & & & 111 & 1.3 \\
\hline BSE-04-021/022 & top first marsh & 320 & 51 & 1.4 & $54^{*}$ & 1.7 \\
\hline BSE-04-071/072 & base first marsh & 680 & & & $105^{*}$ & 1.5 \\
\hline BSE-05-037/038 & base last marsh & 200 & & & 38 & 1.9 \\
\hline \multicolumn{7}{|c|}{ Madison Bay Area } \\
\hline MB-02-133/134 & base last marsh & 840 & & & 134 & 1.6 \\
\hline MB-02-145/146 & top first marsh & 940 & & & 145 & 1.5 \\
\hline MB-02-150/151 & base first marsh & 930 & & & 151 & 1.6 \\
\hline MB-04-107/108 & top intermediate marsh & 720 & & & 108 & 1.5 \\
\hline MB-04-113/114 & base intermediate marsh & 700 & & & 114 & 1.6 \\
\hline MB-04-133/134 & base first marsh & 960 & & & 134 & 1.4 \\
\hline MB-07-114/115 & base last marsh & 600 & & & 115 & 1.9 \\
\hline MB-07-186/187 & top first marsh & 980 & & & 187 & 1.9 \\
\hline MB-07-191/192 & base first marsh & 950 & & & 192 & 2.0 \\
\hline MB-09-046/047 & base recent marsh & 150 & & & 47 & 3.1 \\
\hline MB-09-145/146 & base last marsh & 680 & $100^{* *}$ & 1.9 & 146 & 2.1 \\
\hline MB-09-167/168 & base first marsh & 920 & & & 168 & 1.8 \\
\hline MB-10-152/153 & base last marsh & 660 & & & 153 & 2.3 \\
\hline MB-10-197/198 & base first marsh & 970 & & & 198 & 2.0 \\
\hline \multicolumn{7}{|c|}{ Delarge Area } \\
\hline DL-01A-026/027 & base last marsh & 510 & & & 27 & 0.5 \\
\hline DL-01A-056/057 & top first marsh & 840 & 40 & 1.9 & 57 & 0.7 \\
\hline DL-01A-095/096 & base first marsh & 1050 & & & 96 & 0.9 \\
\hline \multicolumn{7}{|c|}{ Pointe au Chien } \\
\hline PAC-01A-109/110 & base first marsh & 900 & & & 110 & 1.2 \\
\hline PAC-01B-025/026 & base last marsh & 280 & & & 26 & 0.9 \\
\hline PAC-02A-091/092 & top first marsh & 930 & 22 & 4.4 & 92 & 1.0 \\
\hline PAC-02A-112/113 & base first marsh & 980 & & & 113 & 1.2 \\
\hline PAC-02B-055/056 & base last marsh & 430 & & & 56 & 1.3 \\
\hline PAC-03-099/100 & first marsh & 940 & & & 100 & 1.1 \\
\hline PAC-03-128/129 & base first marsh & 950 & & & 129 & 1.4 \\
\hline \multicolumn{7}{|c|}{ Bully Camp Area } \\
\hline SM-01B-027/028 & base recent marsh & 90 & & & 27 & 3.0 \\
\hline SM-01B-072/073 & base last marsh & 420 & $46^{* *}$ & 1.4 & 73 & 1.7 \\
\hline SM-02B-058/059 & base last marsh & 450 & & & 59 & 1.3 \\
\hline SM-02B-085/086 & top first marsh & 860 & 8 & 2.0 & 86 & 1.0 \\
\hline SM-02B-092/093 & base first marsh & 900 & & & 93 & 1.0 \\
\hline
\end{tabular}

Table 5. Minimum subsidence rates inferred from minimum aggradation rates based on marsh thickness (interval rate) and sample depth (depth rate). 


\begin{tabular}{cccccc} 
Method & Type & Period & Range (mm/yr) & Mean (mm/yr) & Reference \\
\hline marker & sed & years & $\mathrm{n} / \mathrm{g}$ & 22 & Rybczyk and Cahoon, 2002 \\
${ }^{137} \mathrm{Cs}$ & sed & decades & $11-17$ & $13^{*}$ & Hatton and others, 1983 \\
${ }^{137} \mathrm{Cs}$ & sed & decades & $3-10$ & $7^{* *}$ & Hatton and others, 1983 \\
${ }^{137} \mathrm{Cs}$ & sed & decades & $6-8$ & 7 & DeLaune and others, 1985 \\
${ }^{14} \mathrm{C}$ & sub & centuries & $1-16$ & 6 & Penland and others, 1988 \\
${ }^{14} \mathrm{C}$ & sub & centuries & $3-7$ & 5 & Roberts and others, 1994 \\
${ }^{14} \mathrm{C}$ & sub & centuries & $0.5-4$ & 2 & this study \\
${ }^{14} \mathrm{C}$ & sub & millennia & $1-5$ & 2 & Penland and others, 1988 \\
${ }^{14} \mathrm{C}$ & sub & millennia & $3-5$ & 4 & Roberts and others, 1994 \\
${ }^{14} \mathrm{C}$ & sub & millennia & $0.1-8$ & 1 & Kulp and Howell, 1998 \\
n/g = not given & & & & \\
* levee & & & & \\
** back marsh & & & &
\end{tabular}

Table 6. Rates (mm/yr) of sediment accumulation (sed) and inferred rates of subsidence (sub) for the Terrebonne and Barataria Basins estimated from isotopic ages $(<5000 \mathrm{BP})$ and direct field measurements (feldspar marker).

The deepest facies penetrated by most vibracores is interlaminated light olive-gray mud and very fine-grained sand (Fig. 5). Some of the mud beds have a distinct light yellowishtan color. In some cores, these alternating layers are distinct and the contacts are horizontal, which suggests that this part of the core is undisturbed.

\section{Interpreted Depositional Events}

The cored sediments represent an upward-fining aggradational stratigraphic succession that is typical of progradational deltaic deposits. The composition, arrangement, and thickness of the deltaic facies are similar to those illustrated by Frazier (1967) for prodelta, delta-fringe, and delta-plain peat deposits of the principal lobes of the Mississippi delta, and by McBride and others (1990) for the Bayou Grand Caillou lobe of the Lafourche delta complex. These shallow-water platform deltas are typically 7-8 m thick (Frazier, 1967; McBride and others, 1990); consequently, the vibracores did not penetrate the underlying older sequence. A possible exception is core DL-01B that penetrated a lower peat and overlying shell hash (Appendix 1), which probably represent a former delta-plain marsh and subsequent transgressive lag associated with a late Holocene flooding event.

The progradational stratigraphic architecture was constructed by the Bayou du Large, Bayou Grand Caillou,
Bayou Terrebonne, and Bayou Lafourche distributaries (Fig. 1) of the Lafourche delta complex (Frazier, 1967; McBride and others, 1990). The vertical stacking of sedimentary facies records shoaling of a shallow interdistributary water body and eventual establishment of an emergent marsh that persisted and aggraded for at least several hundred years. According to radiocarbon dates that help constrain the period of deltalobe deposition, the Lafourche delta complex was initiated about $2500 \mathrm{BP}$ with progradation of the Bayou du Large delta lobe. The most recent delta-plain peat recovered in the vibracores formed less than 400 BP (Frazier, 1967; Penland and others, 1988; Table 3). The interbedded sand and mud facies, penetrated in the deepest cores, represents the prodelta deposits that grade upward into the silty sand and sand of the delta-fringe deposits. The overlying gray mud and peat deposits represent the delta-plain subenvironment. Alternating mud, organic-rich mud, and peat near the top of most cores reflect the balance between sediment supply and relative sealevel rise as the delta-plain marsh was established and then submerged by subsequent flooding. The deepest organic-rich zone represents development of the first marsh, whereas the shallowest mud layer represents the last (youngest) significant flooding event. Re-colonization of marsh plants promoted renewed marsh development that eventually survived until recently. 


\begin{tabular}{|c|c|c|c|c|c|c|}
\hline Date & Data & Land Area $\left(\mathrm{mi}^{2}\right)$ & Water Area $\left(\mathrm{mi}^{2}\right)$ & Total (mi²) & $\%$ Land & $\%$ Water \\
\hline 1956 & habitat & 208.03 & 50.98 & 259.01 & $80.32 \%$ & $19.68 \%$ \\
\hline $1969^{*}$ & pan & 180.89 & 77.93 & 258.83 & $69.89 \%$ & $30.11 \%$ \\
\hline $1974^{* *}$ & CIR & 134.82 & 122.58 & 257.40 & $52.38 \%$ & $47.62 \%$ \\
\hline Oct. 1978 & habitat & 149.24 & 109.73 & 258.97 & $57.63 \%$ & $42.37 \%$ \\
\hline $1 / 6 / 83$ & TM & 152.20 & 106.81 & 259.01 & $58.76 \%$ & $41.24 \%$ \\
\hline $4 / 6 / 84$ & TM & 154.24 & 104.77 & 259.01 & $59.55 \%$ & $40.45 \%$ \\
\hline $9 / 29 / 84$ & TM & 138.32 & 120.69 & 259.01 & $53.41 \%$ & $46.60 \%$ \\
\hline $1 / 19 / 85$ & TM & 146.57 & 112.44 & 259.01 & $56.59 \%$ & $43.41 \%$ \\
\hline $10 / 8 / 87$ & TM & 142.43 & 116.58 & 259.01 & $54.99 \%$ & $45.01 \%$ \\
\hline $1 / 28 / 88$ & TM & 154.43 & 104.58 & 259.01 & $59.62 \%$ & $40.38 \%$ \\
\hline $11 / 21 / 88$ & habitat & 152.93 & 106.03 & 258.96 & $59.06 \%$ & $40.94 \%$ \\
\hline $11 / 1 / 90$ & TM & 126.84 & 132.17 & 259.01 & $48.97 \%$ & $51.03 \%$ \\
\hline $10 / 11 / 91$ & TM & 127.15 & 131.86 & 259.01 & $49.09 \%$ & $50.91 \%$ \\
\hline $10 / 5 / 92$ & TM & 121.32 & 137.69 & 259.01 & $46.84 \%$ & $53.16 \%$ \\
\hline $1 / 25 / 93$ & TM & 130.28 & 128.73 & 259.01 & $50.30 \%$ & $49.70 \%$ \\
\hline $3 / 17 / 94$ & TM & 127.12 & 131.89 & 259.01 & $49.08 \%$ & $50.92 \%$ \\
\hline $11 / 15 / 95$ & TM & 122.54 & 136.47 & 259.01 & $47.31 \%$ & $52.69 \%$ \\
\hline $4 / 7 / 96$ & TM & 126.51 & 132.50 & 259.01 & $48.84 \%$ & $51.16 \%$ \\
\hline $10 / 3 / 97$ & TM & 120.35 & 138.66 & 259.01 & $46.47 \%$ & $53.54 \%$ \\
\hline 2/24/98 & TM & 125.82 & 133.19 & 259.01 & $48.58 \%$ & $51.42 \%$ \\
\hline 1/26/99 & TM & 124.87 & 134.14 & 259.01 & $48.21 \%$ & $51.79 \%$ \\
\hline $11 / 18 / 99$ & $\mathrm{TM}$ & 111.93 & 147.07 & 259.01 & $43.22 \%$ & $56.78 \%$ \\
\hline $10 / 11 / 00$ & TM & 114.24 & 144.77 & 259.01 & $44.11 \%$ & $55.89 \%$ \\
\hline $10 / 30 / 01$ & TM & 114.37 & 144.64 & 259.01 & $44.16 \%$ & $55.84 \%$ \\
\hline 2/27/02 & $\mathrm{TM}$ & 125.85 & 133.16 & 259.01 & $48.59 \%$ & $51.41 \%$ \\
\hline $12 / 28 / 02$ & $\mathrm{TM}$ & 115.75 & 143.26 & 259.01 & $44.69 \%$ & $55.31 \%$ \\
\hline $10 / 20 / 03$ & $\mathrm{TM}$ & 109.67 & 149.34 & 259.01 & $42.34 \%$ & $57.66 \%$ \\
\hline $11 / 7 / 04$ & TM & 112.06 & 146.95 & 259.01 & $43.27 \%$ & $56.73 \%$ \\
\hline
\end{tabular}

* Dec. 15, 1968 and Mar. 9-27, 1969

** Sep. 18 and Oct. 17, 1974

Table 7. Summary of composite land - water conditions for the five study areas in south-central Louisiana between 1956 and 2004.

\section{Historical Subsidence and Erosion of Delta-Plain Marshes}

\section{Methods of Estimating Subsidence and Erosion}

Magnitudes of marsh subsidence and erosion can be estimated by comparing the elevations and vertical offsets (Table 2) of sediment surfaces and stratigraphic contacts correlated between adjacent core pairs. The relative subsidence and erosion between emergent marsh and open-water cores assumes that marsh sediment thickness and stratigraphic positions of correlative contacts are uniform over short distances (tens to hundreds of meters). The amount of erosion at the open-water core site is equal to the difference in marsh sediment thickness between the open-water core and the adjacent marsh core. The amount of subsidence at the openwater core is equal to the elevation difference between the correlated stratigraphic markers between the two adjacent cores. To be precise, the core sections being correlated must not be deformed (shortened), and the erosion and subsidence estimates must equal the vertical displacement between the cores (Table 2). This technique provides a minimum estimate of total subsidence because there is no measurement of the 
absolute amount of historical subsidence of the marsh surface relative to some standard vertical datum. Stated another way, the former marsh preserved beneath open water has subsided more than the adjacent emergent marsh, but the emergent marsh also has subsided some unknown amount.

\section{Bay St. Elaine Area}

The Bay St. Elaine (BSE) study area (Figs.1 and 6) occupies a marginal marine setting where a dense network of tidal channels and ponds of various sizes and orientations segment the present lower delta-plain marsh. This network of tidally influenced and interconnected water bodies, which links directly with Terrebonne Bay and Lake Pelto, provides for the free exchange of water and sediment between the marsh and adjacent bays. At Bay St. Elaine, marsh elevations are approximately $49 \mathrm{~cm}$ above NAVD88 (Table 2, Fig. 7). Water depths where marsh formerly existed are relatively shallow, ranging from $14 \mathrm{~cm}$ above to $35 \mathrm{~cm}$ below NAVD88 and averaging about $8 \mathrm{~cm}$ below NAVD88.

A 1969 aerial photograph (Fig. 6A) shows that core BSE-01 was inadvertently taken in a former tidal channel, and core BSE-05 was taken near a former pond. The other three cores were taken from areas that were previously continuous marsh. Wetland loss near the Bay St. Elaine oil-and-gas field (Fig. 2) began with the dredging of numerous access canals for hydrocarbon and sulfur production. At the coring sites, the present land-water pattern had mostly developed by 1974
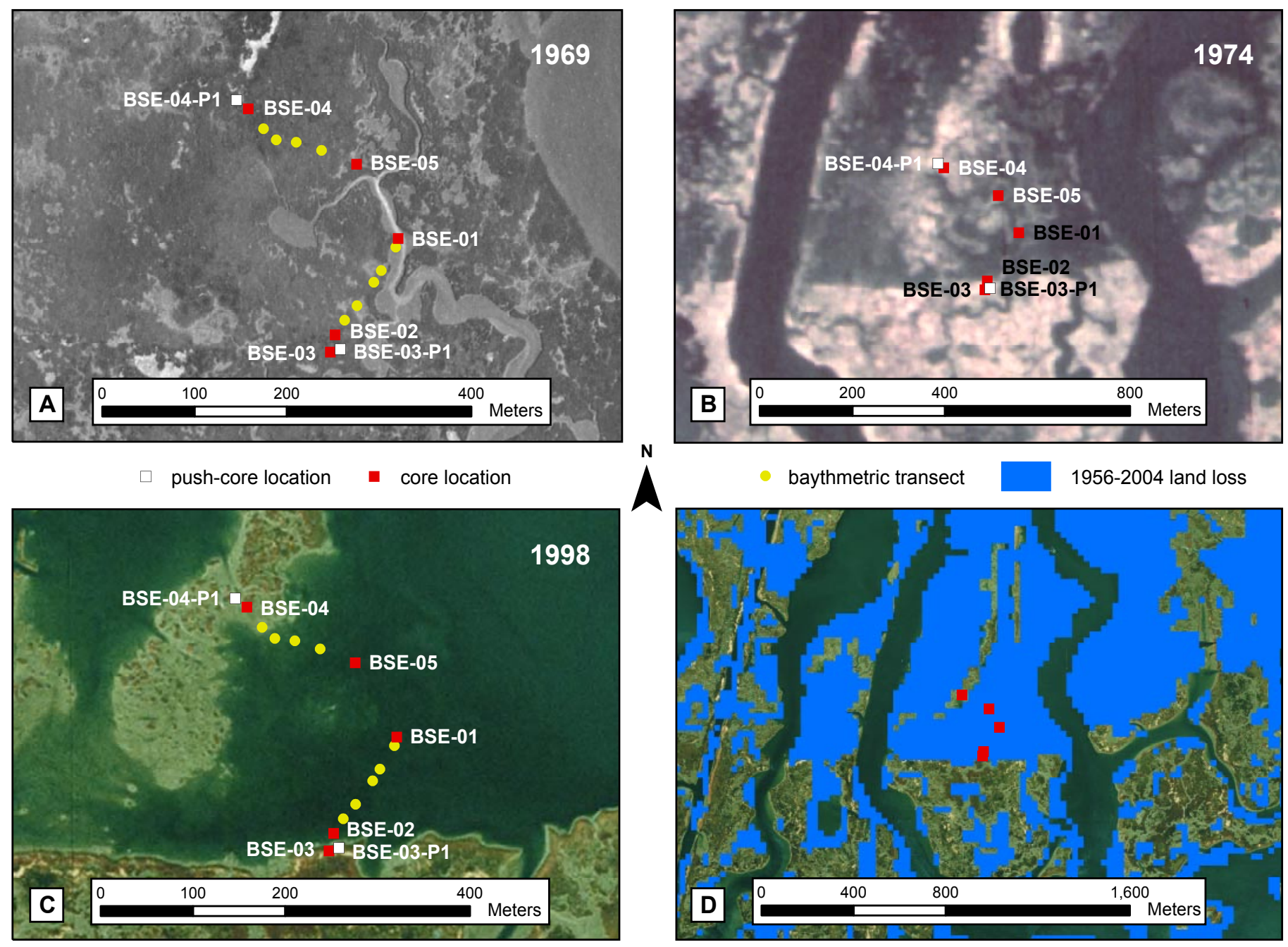

Figure 6. Locations of sediment cores and sediment-surface profiles from the Bay St. Elaine area superimposed on pre- and postsubsidence aerial photographs taken in (A) 1969, (B) 1974, and (C) 1998. The 1974 image is displayed at a smaller scale than the other images to accommodate differences in image resolution. (D) 1956-2004 wetland loss at Bay St. Elaine and the surrounding area superimposed on the 1998 image. The 1998 digital orthophoto quarter quadrangle (D000) imagery was obtained from the Louisiana Oil Spill Coordinator's Office (LOSCO). 
(Fig. 6B). Interior wetland loss at the Bay St. Elaine site has been greatest north of a marsh-edge lineation that appears to coincide with the surface expression of a down-to-the-north fault. A large subsurface fault with comparable orientation and displacement direction is radial to the western margin of the BSE salt dome (Schneider, 1959; Weitz, 1987). The subsurface position of this fault is about $2275 \mathrm{~m}$ north of the inferred surface trace. Using this location and depth of about $2440 \mathrm{~m}$ from the Bay St. Elaine field structure map (Weitz, 1987), the dip between the subsurface fault and marsh lineation would be about $50^{\circ}$.

Initial correlation of peat stratigraphy in cores BSE-03 and BSE-04 was so poor that two short push cores were obtained later at both sites to evaluate shortening of the organic-rich sediments. Detailed measurements of the marsh surface inside and outside the core barrel during the coring operation show that as much as $107 \mathrm{~cm}$ of shortening occurred in the upper $181 \mathrm{~cm}$ of marsh sediments (Appendix 2). To compensate for the shortening, the push-core and vibracore descriptions were combined to create composite stratigraphic sections for cores BSE-03 and BSE-04 (Appendix 1). In addition to the composite descriptions, the original descriptions and photographs of BSE-03, BSE-03-P1, BSE-04, and BSE-04-P1 are included for comparison.

Seven stratigraphic units can be identified in the Bay St. Elaine cores: (1) olive-gray mud with abundant roots or (2) dark olive-gray peat, (3) olive-gray to dark olive-gray mud and muddy peat, (4) dark olive-gray to black peat, (5) gray to olive-gray massive mud, (6) gray to greenish-gray massive silty sand, and (7) gray to olive-gray laminated mud and sand. The unit 4 peat, which is present in all cores, represents the first subdelta marsh. These stratigraphic units generally can be correlated across the study area. A notable exception is core BSE-01, which is missing units 1-3. Although the bottom of the first marsh is preserved in core BSE-01 (Fig. 7), the marsh/ delta-plain deposits above this horizon are replaced by muddy

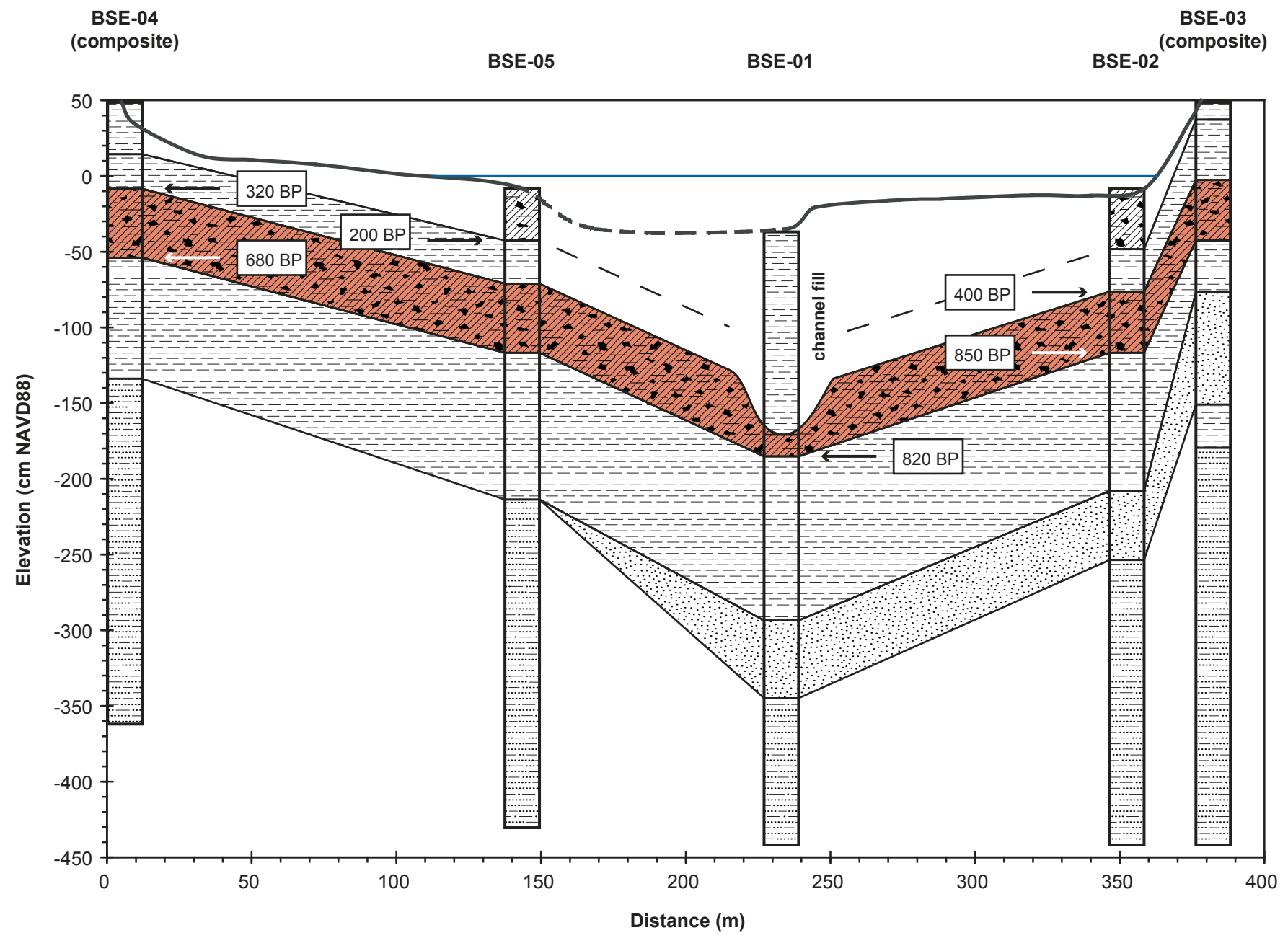

Figure 7. Combined bathymetric profile and stratigraphic cross section for marsh and open-water cores illustrate the magnitude of subsidence (in $\mathrm{cm}$ ) at the Bay St. Elaine area. Locations shown in Figure 6, 50x vertical exaggeration. 
channel fill. As a result of channel scour and erosion, the first marsh (unit 4) is also significantly thinner in core BSE-01 than in the other cores.

The thickness of organic sediments beneath the emergent marsh surface is approximately $100 \mathrm{~cm}$ (composite cores BSE-03 and BSE-04). Mud content in the organic-rich section is highest in the upper $20+\mathrm{cm}$, which is consistent with observations by Hatton and others (1983) for salt marshes in Barataria Bay. Organic-rich sediments thicken to about 110 $\mathrm{cm}$ in cores BSE-02 and BSE-05. The base of the first marsh is deepest $(150 \mathrm{~cm})$ in core BSE-01.

Radiocarbon ages and carbon-isotope ratios from the base of the first marsh (Fig. 7, Table 3) confirm the peat-facies correlation and show that freshwater plants established the marsh about 800 to $850 \mathrm{BP}$. This relatively stable delta-plain marsh persisted as a result of organic-sediment accumulation until about 300 to $400 \mathrm{BP}$, with a long-term average aggradation rate of less than $2 \mathrm{~mm} / \mathrm{yr}$ (Table 5). Subsequent flooding of the first marsh and accumulation of mud and some peat lasted until the most recent, saline, marsh (Table 4) was established about $200 \mathrm{BP}$. That marsh, which forms the modern subaerial delta-plain surface at Bay St. Elaine, also aggraded at a long-term average rate of less than $2 \mathrm{~mm} / \mathrm{yr}$ (Table 5).

The base of the first marsh was used to estimate the magnitudes of subsidence because it was the only contact that could be identified in each core (Table 2). Core correlations suggest that subsidence of the open-water cores BSE-05 and BSE-02 is similar (Fig. 7), despite the proximity of core BSE-02 to the apparent fault scarp. Marsh surface elevations are comparable in cores BSE-03 and BSE-04, the emergent marsh standards, but composite peat thicknesses and basal-peat elevations are about $10 \mathrm{~cm}$ less in core BSE-03 than BSE-04. Water depths and basal-peat elevations are comparable in cores BSE-02 and BSE-05. Greatest estimated subsidence is 129 to $139 \mathrm{~cm}$ at core BSE-01, whereas estimated subsidence at cores BSE-02 and BSE-05 is 73 and $63 \mathrm{~cm}$, respectively. The average marsh elevations $(49 \mathrm{~cm})$ and water depths $(8 \mathrm{~cm})$ provide another estimate of recent wetland subsidence $(57 \mathrm{~cm})$ that is comparable to estimates derived from contact elevations. Estimating erosion at the top of core BSE-01 is not possible because the upper marsh section has been replaced by channel fill.

\section{Madison Bay Area}

The Madison Bay (MB) study area is located in the middle delta plain on the eastern flank of the natural levee of Bayou Terrebonne (Figs. 1 and 8). Before it became a hotspot with one of the highest short-term (decadal) rates of wetland loss (Reed, 1995), the Madison Bay area was characterized by broad expanses of dense marsh with a network of small, widely spaced tidally influenced creeks that formed both dendritic and trellis drainage patterns (Fig. 8A). Prior to marsh breakup, most of the open-water bodies were small, elongate, and oriented approximately parallel to and located near Bayou Terrebonne. Extant marsh elevations at the coring sites range from 17 to $30 \mathrm{~cm}$ above NAVD88 (Table 2), and the average marsh elevation is about $24 \mathrm{~cm}$ above NAVD88. These marsh-remnant elevations are significantly lower relative to NAVD88 than at other delta-plain sites (Table 2), which may reflect substantial prior subsidence. Water depths where marsh formerly existed range from 58 to $108 \mathrm{~cm}$ below NAVD88 and average about $73 \mathrm{~cm}$ below NAVD88 (Figs. 9 and 10).

A 1969 aerial photograph (Fig. 8A) shows that the cores at Madison Bay were taken from areas of former continuous marsh. They were also located well east of the locus of hydrocarbon production from the Lapeyrouse field (Fig. 2). Wetland loss at Madison Bay progressed as widespread areas of drowned marsh (Fig. 8B) that eventually became permanently submerged (Fig. 8C). During submergence, the tidal creeks and small water bodies became enlarged and eventually merged to produce even larger areas of open water.

The Madison Bay cores presented in Morton and others (2003) were reexamined and the organic-rich section was further subdivided into three units. The stratigraphic revisions also involved minor changes in depths of contacts between stratigraphic units, resulting in small differences (typically a few $\mathrm{cm}$ ) in estimated magnitudes of subsidence and erosion. The revised correlations resulted in six stratigraphic units: (1) olive-gray to black peat, (2) olive-gray mud and organic-rich mud, (3) olive gray to black peat and muddy peat, (4) olivegray mud and organic-rich mud, (5) olive-gray silt, muddy or silty sand, and sand, and (6) olive-gray laminated sand and mud. The unit 1 peat represents the last subdelta marsh; the uppermost (4 to $55 \mathrm{~cm}$ ) unit 1 sediments consist of mud and muddy peat that represent the most recent (modern) marsh deposits. The unit 4 peat represents the first subdelta marsh. These stratigraphic units generally can be correlated across the study area. Organic-rich delta-plain deposits range in thickness from $170-210 \mathrm{~cm}$. Some deposits at the top of the massive mud (unit 5) contain several thin organic bands. These immature peat deposits, which are absent in core MB-04, represent initial patches of marsh accumulation before the first persistent marsh was widely established.

Radiocarbon ages and carbon-isotope ratios from the base of the first marsh (Figs. 9 and 10, Table 3) confirm the peatfacies correlation and show that freshwater plants established the first persistent marsh by approximately 950 BP. Since the first marsh was colonized, the long-term average rate of sediment accumulation has been $2 \mathrm{~mm} / \mathrm{yr}$ or less (Table 5). The duration of this first marsh probably was short (less than 200 years?) because it produced only a thin $(<10 \mathrm{~cm})$ peat layer. However, durations of marshes represented by thin peat layers are poorly constrained because mixing of organic carbon yields first and last ages that are within the 
margin of error. Furthermore, the relatively brief duration of marsh formation and resolution limitations of ${ }^{14} \mathrm{C}$ technology caused chronostratigraphic reversals in a few cores (Figs. 9 and 10). Subsequent gradual flooding of the first marsh, with accumulation of mud and some organics, lasted until the last marsh, a freshwater type (Tables 3 and 4), became established about 650 BP. Organic accumulation of the last marsh has been nearly continuous, although the marsh changed to a saline type by $150 \mathrm{BP}$ as the delta plain submerged. This last, and most persistent, marsh aggraded at a long-term average rate of approximately $2 \mathrm{~mm} / \mathrm{yr}$, although the modern (saline) marsh aggraded at an average rate of approximately $3 \mathrm{~mm} / \mathrm{yr}$ (Table 5).

Core correlations suggest that subsidence at open-water coring sites is similar around the margin but increases toward the center of wetland loss (Figs. 9 and 10). Based on NAVD88 elevations from the base of the first marsh, the minimum subsidence around the margin of open water ranges from 50 to $65 \mathrm{~cm}$ (Table 2) and averages about $59 \mathrm{~cm}$, whereas subsidence near the center (core sites MB-04 and MB-05) is about $75 \mathrm{~cm}$. These values compare well with those derived using the base of the last marsh. Erosion of the former marsh sediments at most Madison Bay cores ranges from 23 to $37 \mathrm{~cm}$ (Table 2) and averages about $30 \mathrm{~cm}$. The high erosion value $(64 \mathrm{~cm})$ calculated for core MB-05 probably includes some core shortening in unit 2 of core MB-05 relative to core MB-10 (Figs. 9 and 10). Overall, these values indicate that subsidence is responsible for about two-thirds of the differences between marsh elevations and water depths, whereas erosion is responsible for the other third - subsidence has been twice as important as erosion in altering the landscape at Madison Bay.

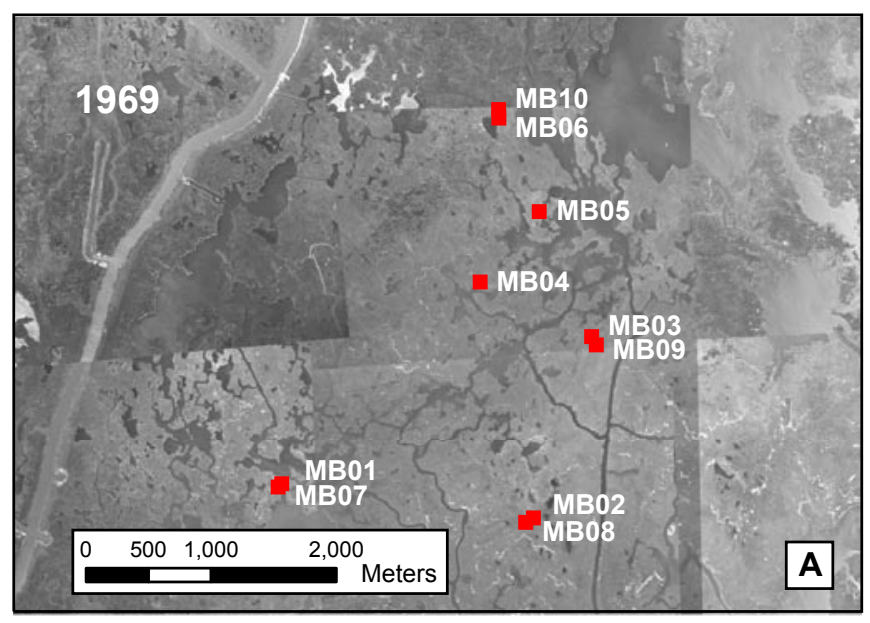

- core location

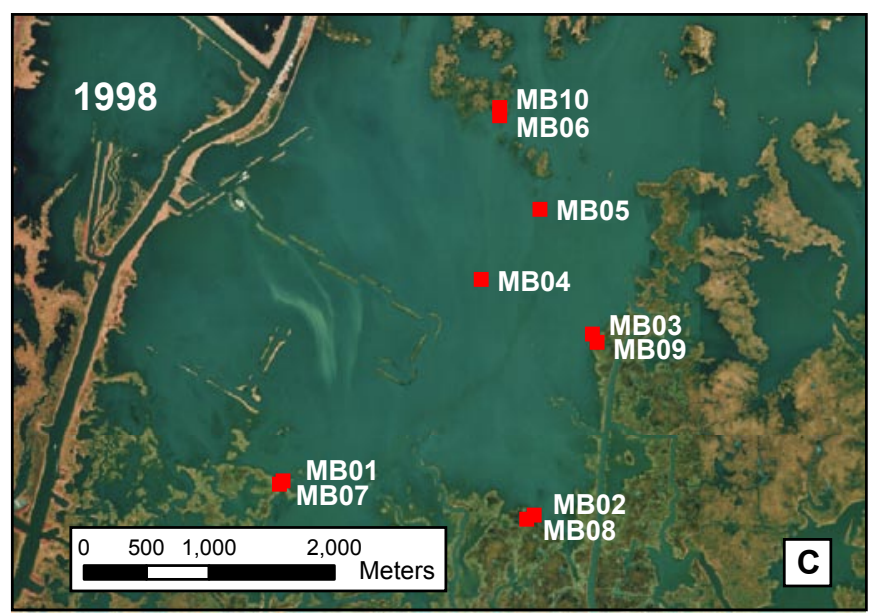

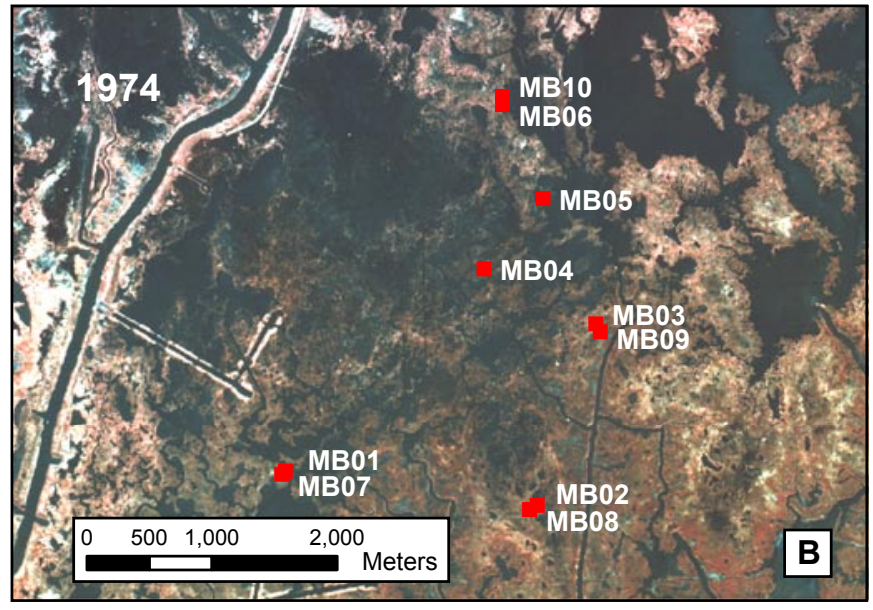

$\mathrm{N}$
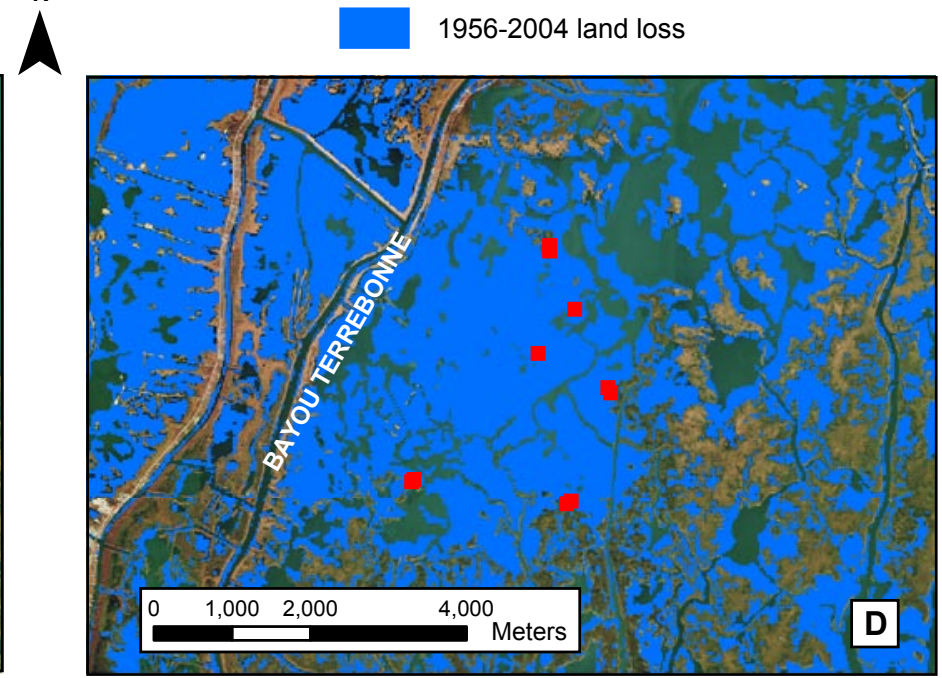

Figure 8. Locations of sediment cores and sediment-surface profiles from the Madison Bay area superimposed on pre- and post-subsidence aerial photographs taken in (A) 1969, (B) 1974, and (C) 1998. (D) 1956-2004 wetland loss at Madison Bay and the surrounding area superimposed on the 1998 image. The 1998 D000 imagery was obtained from the Louisiana Oil Spill Coordinator's Office (LOSCO). 


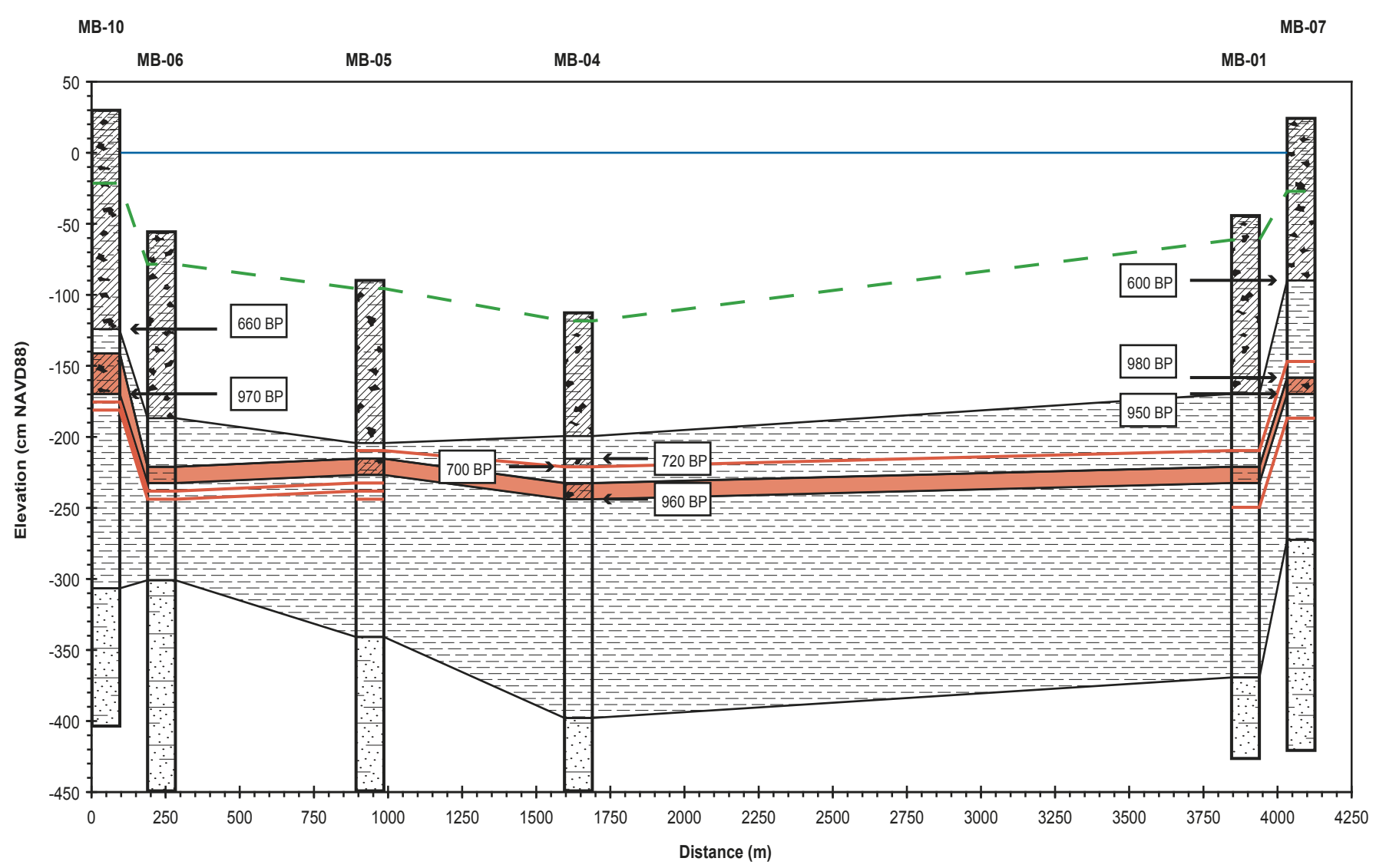

Figure 9. Combined bathymetric profile and stratigraphic cross section for marsh and open-water cores MB-10 to MB-07 illustrate the magnitude of subsidence and wetland erosion (in $\mathrm{cm}$ ) at the Madison Bay area. Dashed green line shows correlation of the base of the muddy recent marsh sediments, and red lines show correlation of organic-rich bands within the cores. Locations shown in Figure 8, 500x vertical exaggeration.

\section{DeLarge Area}

The DeLarge (DL) study area (Figs. 1 and 11) is located in the upper delta plain between Bayou Grand Caillou and Bayou du Large, and west of the Houma Navigation Canal. Data collection at DeLarge was limited because of extreme weather conditions. Marsh elevation at core DL-01B, which is $32 \mathrm{~cm}$ above NAVD88 (Fig. 12), is substantially lower than at the Bay St. Elaine and Bully Camp sites (Table 2), perhaps as a result of prior subsidence. Where emergent marsh formerly existed between cores DL-01A and DL-01B (Fig. 11A), water depths range from 47 to $71 \mathrm{~cm}$ and average about $53 \mathrm{~cm}$ below NAVD88 (Appendix 1, Fig. 12).

Local patterns of wetland loss are approximately centered over but extend well beyond the DeLarge oil-andgas field (Fig. 2). An extensive network of man-made canals and associated embankments of dredged material cross the area of wetland loss. Wetland loss near the coring site is extensive, with only isolated marsh patches remaining in an open-water setting. There is no obvious surface expression of faults or other structures controlling wetland loss; however, the approximate northern boundary of complete wetland loss appears to coincide with both the Falgout Canal and the projected surface trace of the Golden Meadow Fault (Kuecher and others, 2001). North of this zone, wetland loss is prevalent, but the landscape is dominated by broken marsh rather than open water, as at the DeLarge site. The surface trace of the Lake Hatch Fault bounds the northernmost extent of wetland loss in this area.

Both cores from DeLarge recovered two distinct organic deposits separated by mud with low organic content. Measuring the depths and thicknesses of the first and second peat deposits is imprecise because the contacts are gradational (Appendix 1). The basal contact of the first marsh is 100$110 \mathrm{~cm}$ below the surface.

A composite stratigraphic section of the two cores includes the following units: (1) olive-gray peat, (2) olivegray to gray mud, (3) olive-gray peat, (4) gray to olive-gray mud, (5) greenish-gray to gray, laminated sand and mud, (6) shell hash, (7) black organic mud, and (8) dark olive-gray to 


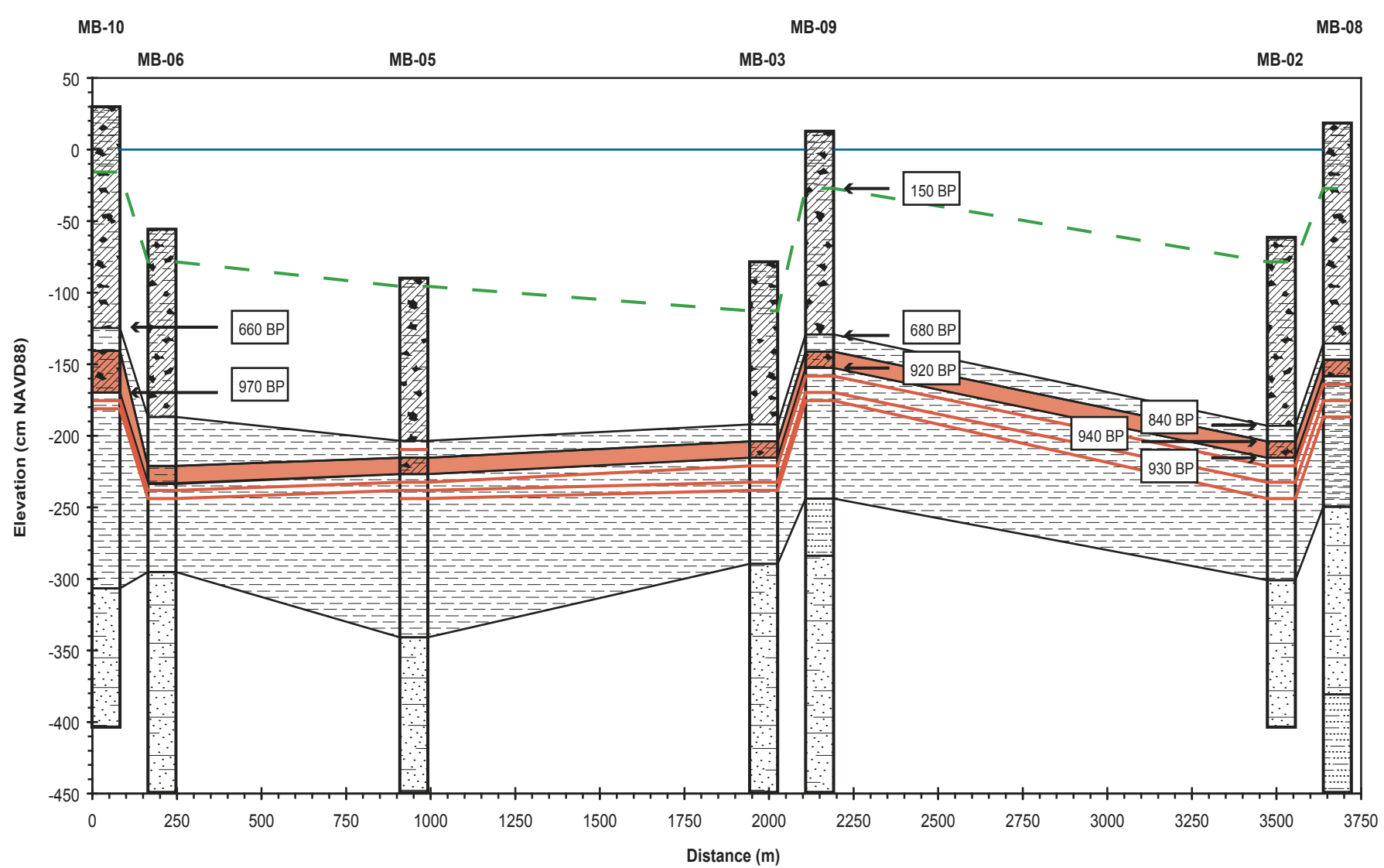

Figure 10. Combined bathymetric profile and stratigraphic cross section for marsh and open-water cores MB-10 to MB-08 illustrate the magnitude of subsidence and wetland erosion (in $\mathrm{cm}$ ) at the Madison Bay area. Dashed green line shows correlation of the base of the muddy recent marsh sediments, and red lines show correlation of organic-rich bands within the cores. Locations shown in Figure 8, 500x vertical exaggeration.

greenish-gray mud. The oldest stratigraphic units $(6,7$, and 8$)$ are present only in core DL-01B, which is about $200 \mathrm{~cm}$ longer than core DL-01A. An organic-rich layer within unit 5 near the base of core DL-01A does not appear to correlate with unit 7 in core DL-01B. There is good correlation of the upper lithologies and contacts (units 1-5) between the two cores. The unit 3 peat probably represents the first marsh in the study area, although a lower organic layer is present in both cores.

Radiocarbon ages and carbon-isotope ratios from core DL-01A reveal that freshwater plants colonized the first marsh about 1,000 BP (Fig. 12, Table 3). That marsh persisted for about 150 years as a result of accumulation of organic sediments at a long-term average aggradation rate of about $2 \mathrm{~mm} / \mathrm{yr}$ (Table 5). The first marsh surface was flooded and clastic deposition predominated until about $500 \mathrm{BP}$ when the most recent freshwater-marsh ecosystem was established. Until recently, the last marsh has persisted with long-term average aggradation rates of $0.5 \mathrm{~mm} / \mathrm{yr}$.

Subsidence estimates at the open-water site (DL-01A) derived from NAVD88 elevations at the base of the first and last marshes range from 68 to $79 \mathrm{~cm}$, respectively (Table 2). Stratigraphic correlation of unit 1 indicates that where core DL-01A was taken, surficial erosion of the uppermost (last marsh) peat was minimal (about $2 \mathrm{~cm}$ ).

\section{Pointe au Chien Area}

The Pointe au Chien (PAC) study area (Figs. 1 and 13) is in an upper delta-plain setting between Bayou Pointe au Chien and Bayou St. Jean Charles. Where cores were collected, marsh elevations range from 32 to $39 \mathrm{~cm}$ above NAVD88. Where emergent marsh formerly existed between the Pointe au Chien coring sites (Fig. 13A), present water depths range from 24 to $68 \mathrm{~cm}$, and average about $48 \mathrm{~cm}$ below NAVD88 (Fig. 14).

The Pointe au Chien study area is located in an east-west regional trend of historic wetland loss that extends from Lake De Cade to Bayou Lafourche. Within this trend, wetland loss between Bayou Terrebonne and Bayou Lafourche is extensive, with mostly open water broken only by the elevated levees along the distributaries (Fig. 2). Wetland loss in the PAC 

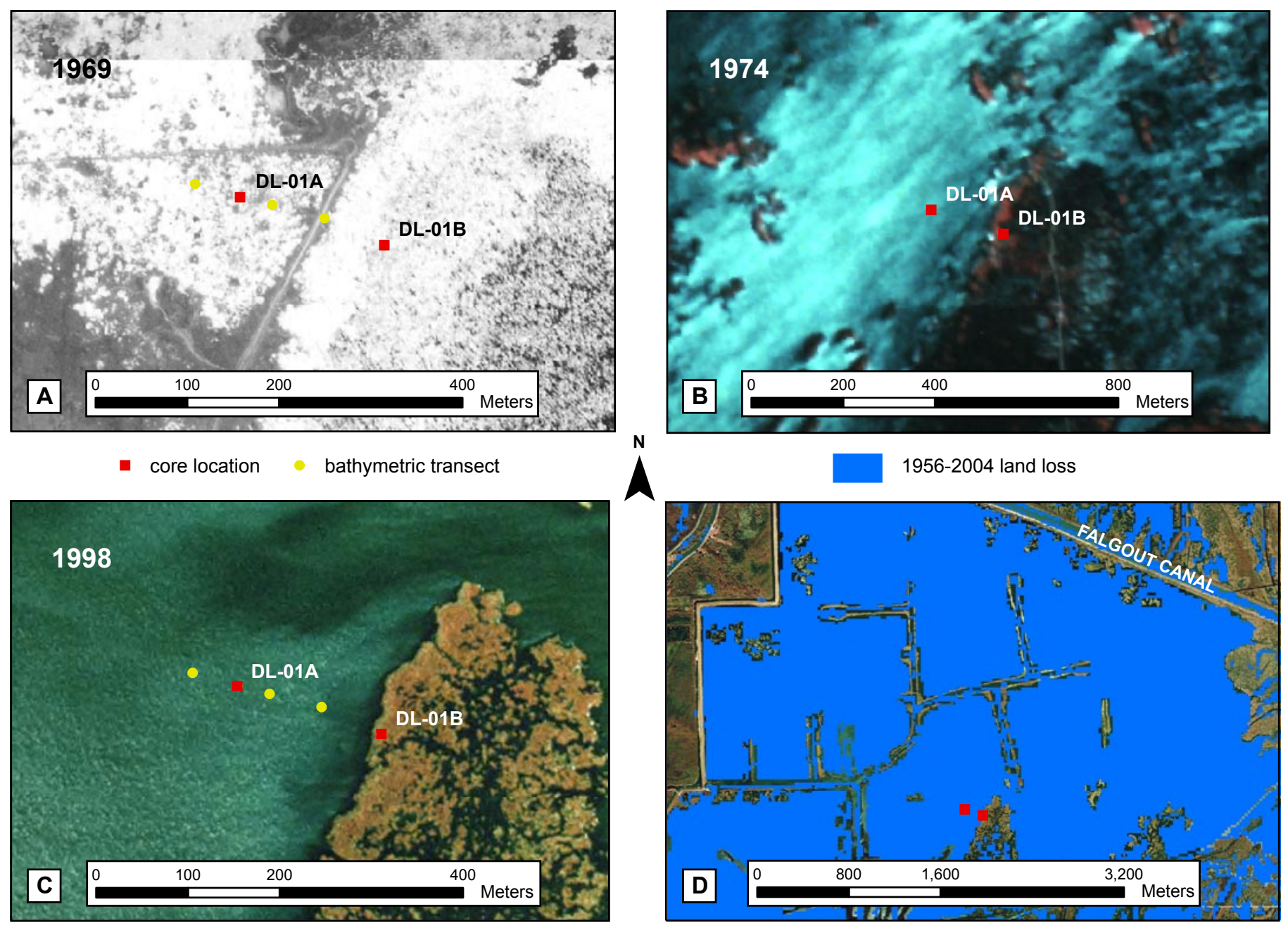

Figure 11. Locations of sediment cores and sediment-surface profiles from the DeLarge area superimposed on pre- and postsubsidence aerial photographs taken in (A) 1969, (B) 1974, and (C) 1998. The 1974 image is displayed at a smaller scale than the other images to accommodate differences in image resolution. (D) 1956-2004 wetland loss at DeLarge and the surrounding area superimposed on the 1998 image. The 1998 DO00 imagery was obtained from the Louisiana Oil Spill Coordinator's Office (LOSCO).

study area is nearly complete, with isolated marsh patches surrounded by open water. Comparison of aerial photographs indicates that much of the wetland loss occurred between 1969 and 1974 (Fig. 13). There is no obvious surface expression of faults or other structures controlling patterns of wetland loss, although the projected surface trace of the Golden Meadow fault (Kuecher and others, 2001) is 500 to 1,000 m south of the core locations.

A 1952 aerial photograph shows that side-cast disposal of sediment excavated for a pipeline trench may have artificially increased marsh thickness in core PAC-02B, in which the uppermost (last marsh) peat deposits are slightly thicker than in other cores. However, close examination did not reveal any sedimentological change in the last marsh deposits that would indicate a sudden influx of reworked clastic material. Sediment accumulation related to pipeline emplacement might exaggerate the erosion estimates of adjacent cores, but it would not alter the estimated magnitudes of subsidence.

The PAC cores recovered two or more distinctly different organic deposits. The two youngest peats are separated by moderately thick mud with low organic content. The basal contact of the first marsh is approximately $100-130 \mathrm{~cm}$ below the surface. Six stratigraphic units can be identified in the PAC cores: (1) dark olive-gray peat, (2) gray to olive-gray, massive to laminated mud, (3) olive-gray to black peat, (4) gray to olive-gray or black, massive to laminated mud and organic mud, (5) olive-gray to gray, massive to laminated silt, sand, and/or mud, and (6) olive-gray laminated mud and sand. The unit 3 peat represents the first subdelta marsh.

Stratigraphic correlation of the organic-rich section between core pairs PAC-01A-01B and PAC-02A-02B is excellent; however, the submerged marsh in core PAC-01A is 7 


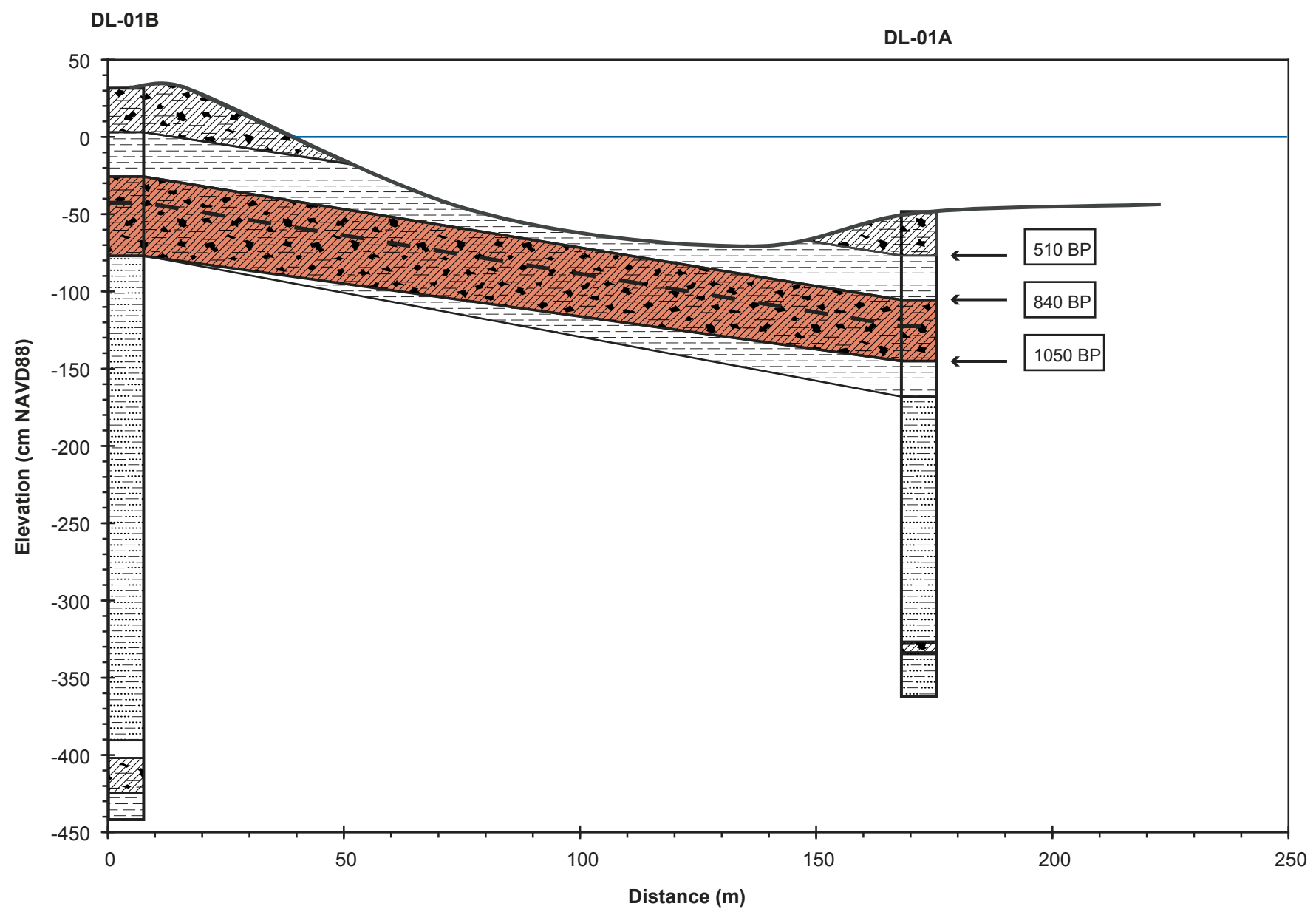

Figure 12. Combined bathymetric profile and stratigraphic cross section for marsh and open-water cores illustrate the magnitude of subsidence and wetland erosion (in $\mathrm{cm}$ ) at the DeLarge area. Dashed line shows correlation of a muddy lens within the unit 3 peat. Locations shown in Figure 11, 30x vertical exaggeration.

$\mathrm{cm}$ thicker than the emergent marsh in adjacent core PAC-01B. This difference may be the result of true stratigraphic thickening to the west, or an artifact of peat compaction in core PAC-01B. In general, there is good correlation from core PAC-02A to core PAC-01B, although thicknesses of the lower clastic units are variable. Correlations to the west with cores PAC-04 and PAC-05, however, are less certain and are likely an artifact of compaction in core PAC-05.

Radiocarbon ages and carbon-isotope ratios of peat samples from Pointe au Chien indicate that freshwater plants established the first marsh about $950 \mathrm{BP}$. The duration of this wetland is uncertain because the ages of samples near the top of the peat are within the error range of ages from the base of the peat (Fig. 14, Table 3). After the first marsh was flooded, as much as $50 \mathrm{~cm}$ of mud was deposited before the last marsh was established about 300 to $400 \mathrm{BP}$. Since then, long-term rates of marsh aggradation have averaged about $1 \mathrm{~mm} / \mathrm{yr}$ (Table 5).
The magnitudes of land subsidence are similar across the Pointe au Chien area of wetland loss (Fig. 14), and highest marsh elevations coincide with the areas of least subsidence. Marsh cores PAC-01B and PAC-05 suggest that the base of the last marsh was near NAVD88 before the area subsided. Consequently, comparisons of water cores with marsh core PAC-02B may underestimate total subsidence because the marsh remnant at core PAC-02B has subsided more than the adjacent emergent marsh. The magnitude of subsidence at the Pointe au Chien cores was estimated from the NAVD88 elevation at the base of the last marsh because correlation of the first marsh horizon is uncertain in the western part of the study area. Core PAC-02B has subsided 16 to $37 \mathrm{~cm}$ relative to the adjacent marsh at cores PAC-01B and PAC-05. Subsidence at the open water sites ranged from 75 to $117 \mathrm{~cm}$ and averaged about $88 \mathrm{~cm}$ (Table 2). The variable thickness of marsh sediments across the Pointe au Chien area makes estimates of erosion at the open-water sites imprecise. Nevertheless, erosion 

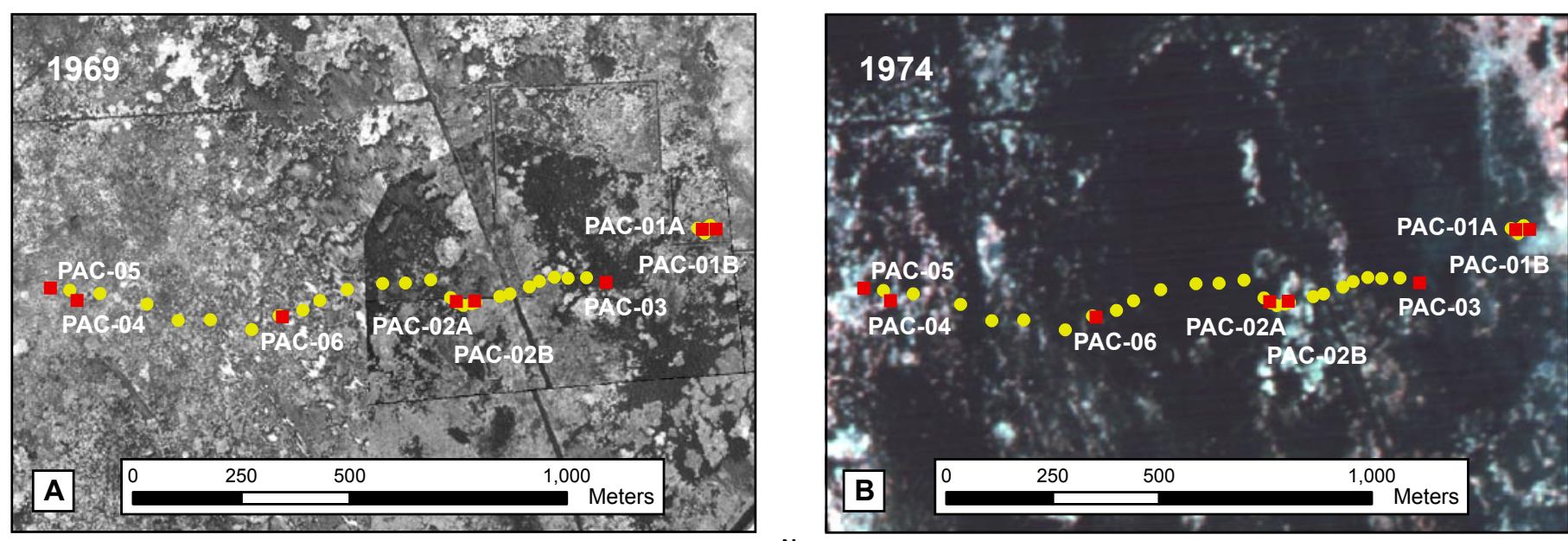

- core location bathymetric transect
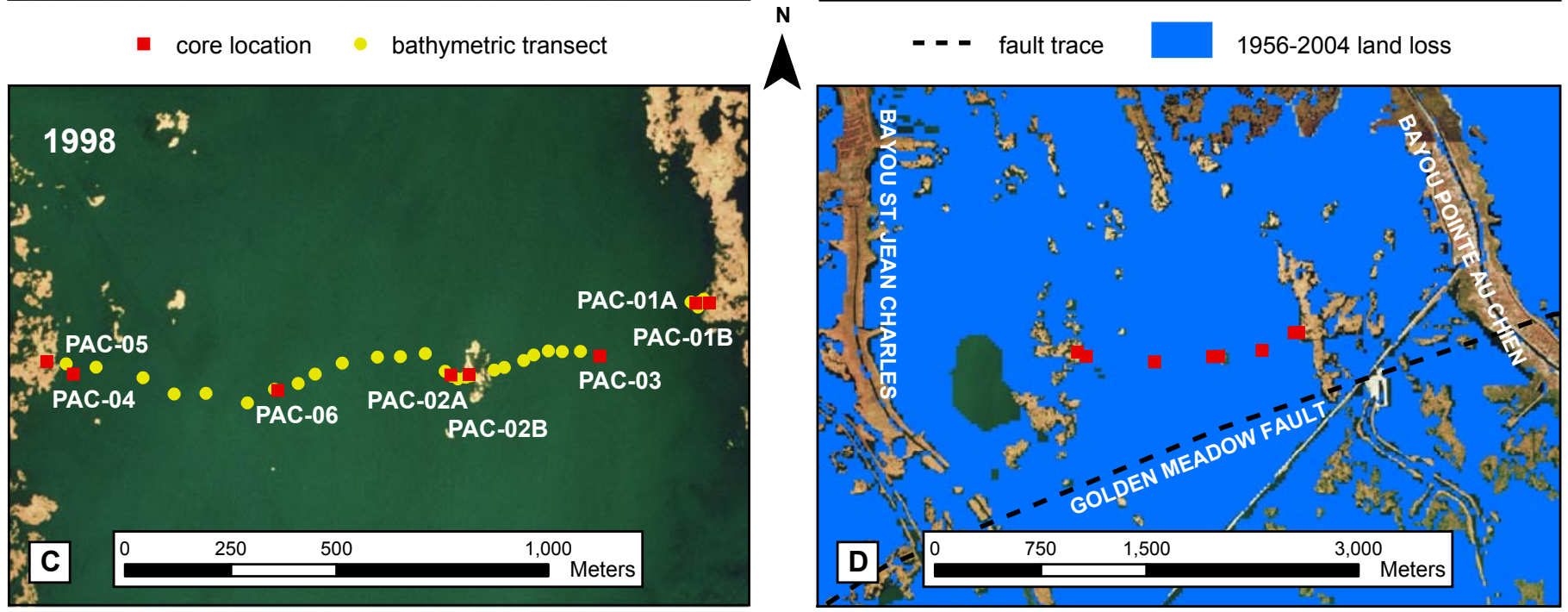

Figure 13. Locations of sediment cores and sediment-surface profiles from the Pointe au Chien area superimposed on aerial photographs taken in (A) 1969, (B) 1974, and (C) 1998. (D) 1956-2004 wetland loss at Pointe au Chien and the surrounding area superimposed on the 1998 image. The 1998 DO00 imagery was obtained from the Louisiana Oil Spill Coordinator's Office (LOSCO).

of the last marsh surface ranged from 0 to $14 \mathrm{~cm}$, which is minor compared to magnitudes of subsidence.

\section{Bully Camp Area}

The Bully Camp study area (Figs. 1 and 15) is located in the upper delta plain just west of Bayou Lafourche. The study area was informally named Sulfur Mine (SM), because sulfur was mined at the site from the late 1960s through the late 1970s. Marsh elevations and water depths at Bully Camp generally are greater than at any of the other coring sites (Appendix 1, Fig. 16). Marsh elevations at core sites SM-01B and SM-02B are 55 and $49 \mathrm{~cm}$, respectively, which is slightly higher than at the other coring sites (Table 2). Marsh elevation at core SM-03 is $8 \mathrm{~cm}$ below NAVD88, probably as a result of differential subsidence. Recent images show that core SM-03 was located on a visibly "wet" (drowned) marsh remnant. Near the emergent marsh, water depths range from 35 to $130 \mathrm{~cm}$, but to the east, toward the former sulfur mine, they increase to more than $6 \mathrm{~m}$ below NAVD88 (Fig. 17).

The Bully Camp study area is within the east-west regional trend of extensive historic wetland loss between Bayou Terrebonne and Bayou Lafourche (Fig. 2). Wetland loss extends east of Bayou Lafourche, but the levees along this distributary form natural topographic highs that have not been submerged as a result of delta plain subsidence. South of the study area near the Golden Meadow oil-and-gas field, the levees are significantly narrower, and wetland loss is more continuous across Bayou Lafourche. South of Golden Meadow, extensive wetland loss is primarily restricted to the east side of Bayou Lafourche. Wetland loss at Bully Camp is nearly complete, with isolated marsh remnants in an open-water 


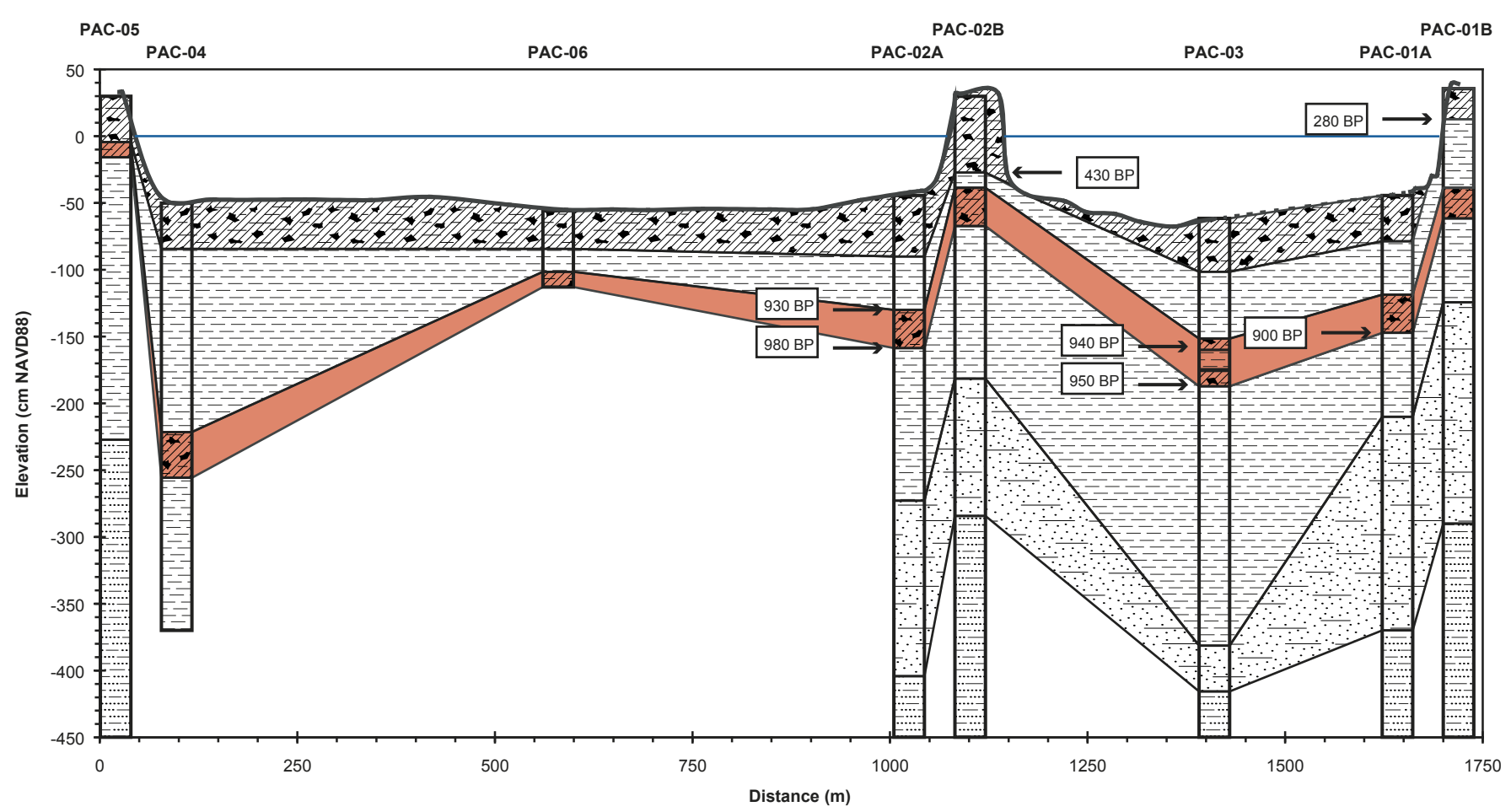

Figure 14. Combined bathymetric profile and stratigraphic cross section for marsh and open-water cores illustrate the magnitude of subsidence and wetland erosion (in $\mathrm{cm}$ ) at the Pointe au Chien area. Locations shown in Figure 13, 200x vertical exaggeration.

setting. There is no obvious surface expression of faults that might control patterns of wetland loss. However, the central "hole" of wetland loss - a pit that is more than $6 \mathrm{~m}$ deep - coincides with the 300-m top-of-salt contour of the Bully Camp dome (Fig. 15).

Wetland loss at Bully Camp was associated initially with the extensive dredge-and-fill activities associated with oiland-gas development and later sulfur extraction. Production of these natural resources required the drilling of numerous wells located in the marsh.

Eight stratigraphic units can be identified in the Bully Camp cores: (1) dark olive-gray to black peat, (2) dark olivegray massive organic mud, (3) dark olive-gray peat or muddy peat, (4) olive-gray to dark olive-gray, massive to laminated organic mud, (5) light olive-gray, massive to laminated mud, (6) light olive-gray, massive to laminated sand, silty sand, and/or mud, (7) light olive-gray to olive-gray laminated mud and sand, and (8) olive-gray to gray mud. Total thickness of the organic-rich deposits ranges from 80 to $130 \mathrm{~cm}$ (Table 2). The unit 1 peat represents the last subdelta marsh; the uppermost ( 27 to $34 \mathrm{~cm}$ ) unit 1 sediments in the emergent marsh cores consist of mud and muddy peat that represent the most recent (modern) marsh deposits. The unit 3 muddy peat likely represents development of the first marsh, but definition of this horizon is somewhat ambiguous because the first marsh peat is muddier at Bully Camp than at most of the other areas.
The unit 3 peat has $75-80 \%$ organics, whereas first marsh peats at other study areas typically are characterized by $>90 \%$ organics. Furthermore, the unit 3 peat occurs within a section of organic-rich mud (units 2 and 4). The stratigraphic units generally can be correlated across the study area, with some exceptions. The first marsh unit does not appear to be present in core SM-01B. The base of what is assumed to be the unit 1 peat (from overall lithology and correlative thickness) in this core is fairly sharp, with a dark-colored, organic-rich muddy section immediately below.

Cores were obtained near the dredged canals where some marsh still is emergent (Fig. 15). Because most of the cores are close to the dredged canals, they may have been affected by artificial landscape changes. Placement of dredged material in the adjacent marsh would increase the marsh sediment thickness and possibly the marsh elevation. Considering these historical events, the upper $5 \mathrm{~cm}$ of silty sand in core SM-04 and the upper $27 \mathrm{~cm}$ of peat and mud in core 01B were interpreted as recent deposits that post-date normal marsh sedimentation. The very young age of the marsh surface in core SM-01B (Table 3) supports this interpretation. Therefore, those lithologies were eliminated from the calculations used to estimate subsidence and erosion. Also, because correlating the first peat (unit 3) was problematic, the last peat (unit 1) was used to estimate subsidence and erosion (Fig. 16, Table 2). 

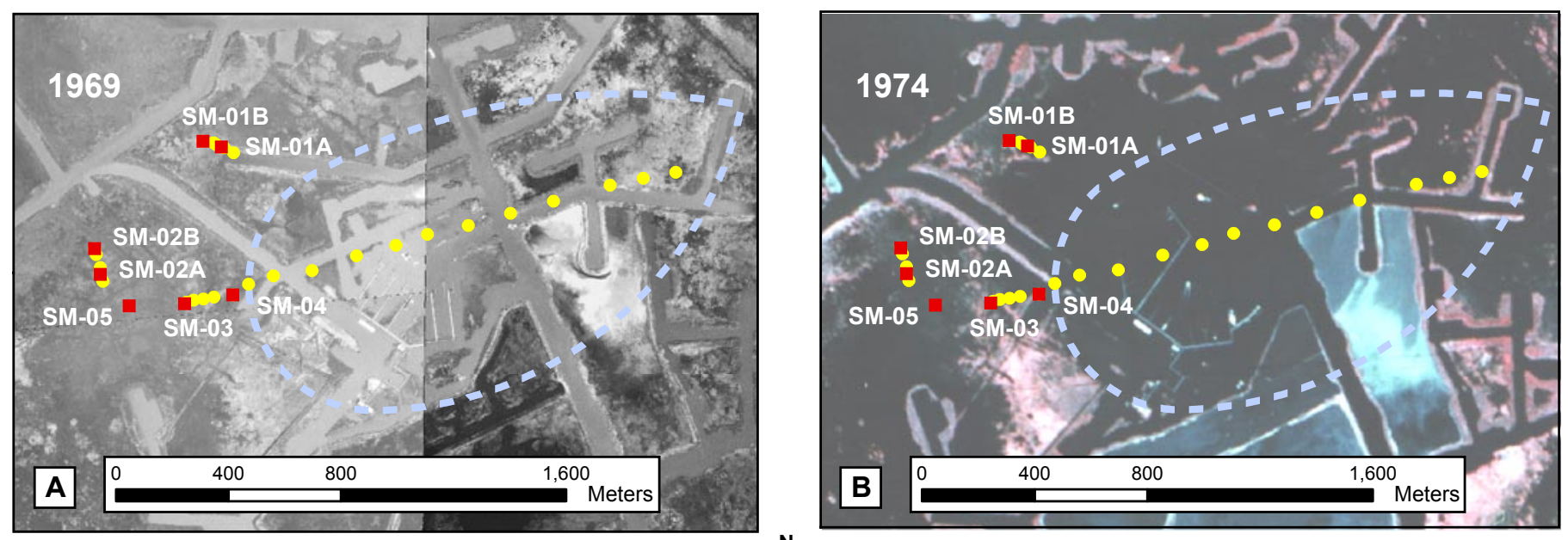

- core location bathymetric transect

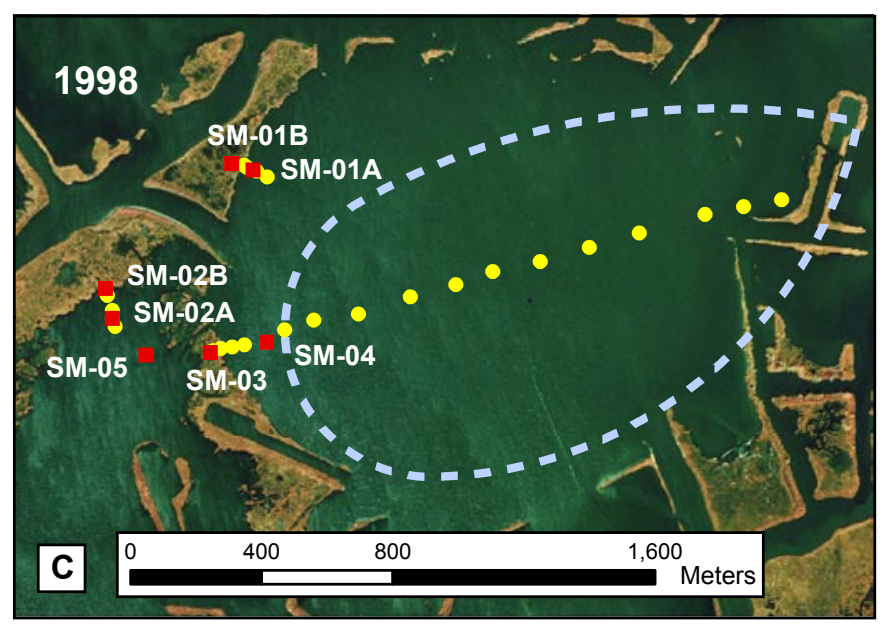

$\Lambda$

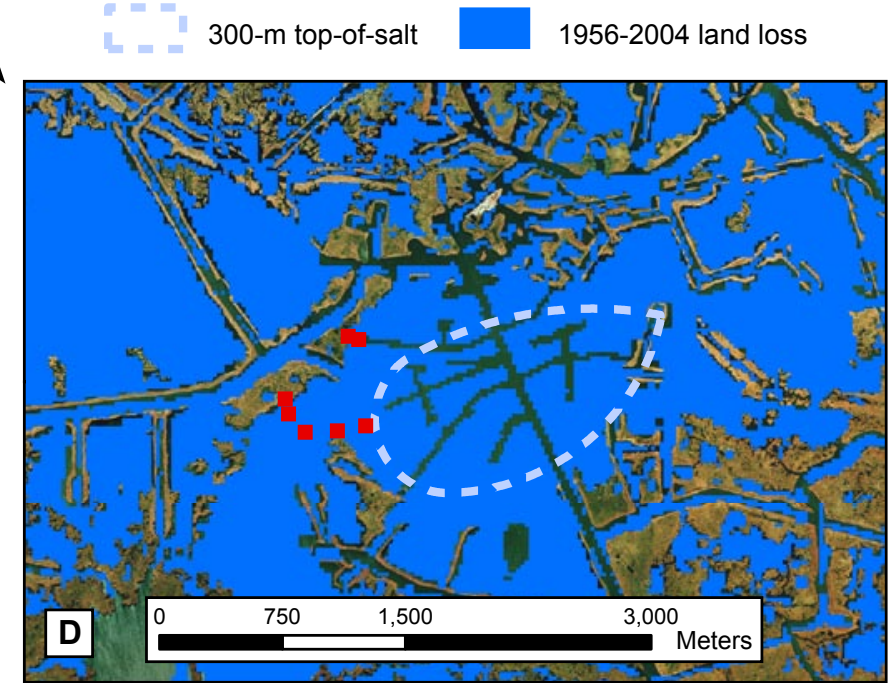

Figure 15. Locations of sediment cores and sediment-surface profiles from the Bully Camp area superimposed on pre- and post-subsidence aerial photographs taken in (A) 1969, (B) 1974, and (C) 1998. (D) 1956-2004 wetland loss at Bully Camp and the surrounding area superimposed on the 1998 image. Location of 300-m top-of-salt contour after Stipe and Spillers (1960). The 1998 DOQ0 imagery was obtained from the Louisiana Oil Spill Coordinator's Office (LOSCO).

Radiocarbon ages and carbon-isotope ratios of peat samples from Bully Camp indicate that freshwater plants established the first marsh about 900 BP. The duration of this wetland is uncertain because the ages of samples near the top of the peat are within the error range of ages from the base of the peat (Fig. 16). After the first marsh was flooded, as much as $25 \mathrm{~cm}$ of mud was deposited before the last marsh was established about $450 \mathrm{BP}$. Aggradation rates are typically 1 to $2 \mathrm{~mm} / \mathrm{yr}$, but approach $3 \mathrm{~mm} / \mathrm{yr}$ in the last century based on a date at the base of the recent (muddy) marsh in core SM-01B (Table 5).

There is more variability in subsidence between marsh and open-water cores at Bully Camp than at either Bay St. Elaine or Pointe au Chien. Subsidence at the open-water sites ranges from 68 to $149 \mathrm{~cm}$ and averages about $98 \mathrm{~cm}$. As at Pointe au Chien, it appears that one of the remnant-marsh sites
(SM-03) has subsided more relative to the other two marsh sites. The base of the last marsh at SM-03 is $51 \mathrm{~cm}$ lower than at SM-01B and $59 \mathrm{~cm}$ lower than at SM-02B. Erosion of the uppermost mars sediments at most of the open-water sites is minor at SM-05 and SM-01A but may be as much as $26 \mathrm{~cm}$ at core SM-02A and $35 \mathrm{~cm}$ at core SM-04.

\section{Regional Peat Stratigraphy}

Comparison of the uppermost stratigraphic units shows that delta-plain depositional history is influenced by geographic position within the delta-lobe and paleo-environmental setting (e.g., interdistributary and distributary flank areas). The most significant differences in peat stratigraphy correlate with location relative to the Bayou Terrebonne delta sublobe. West 


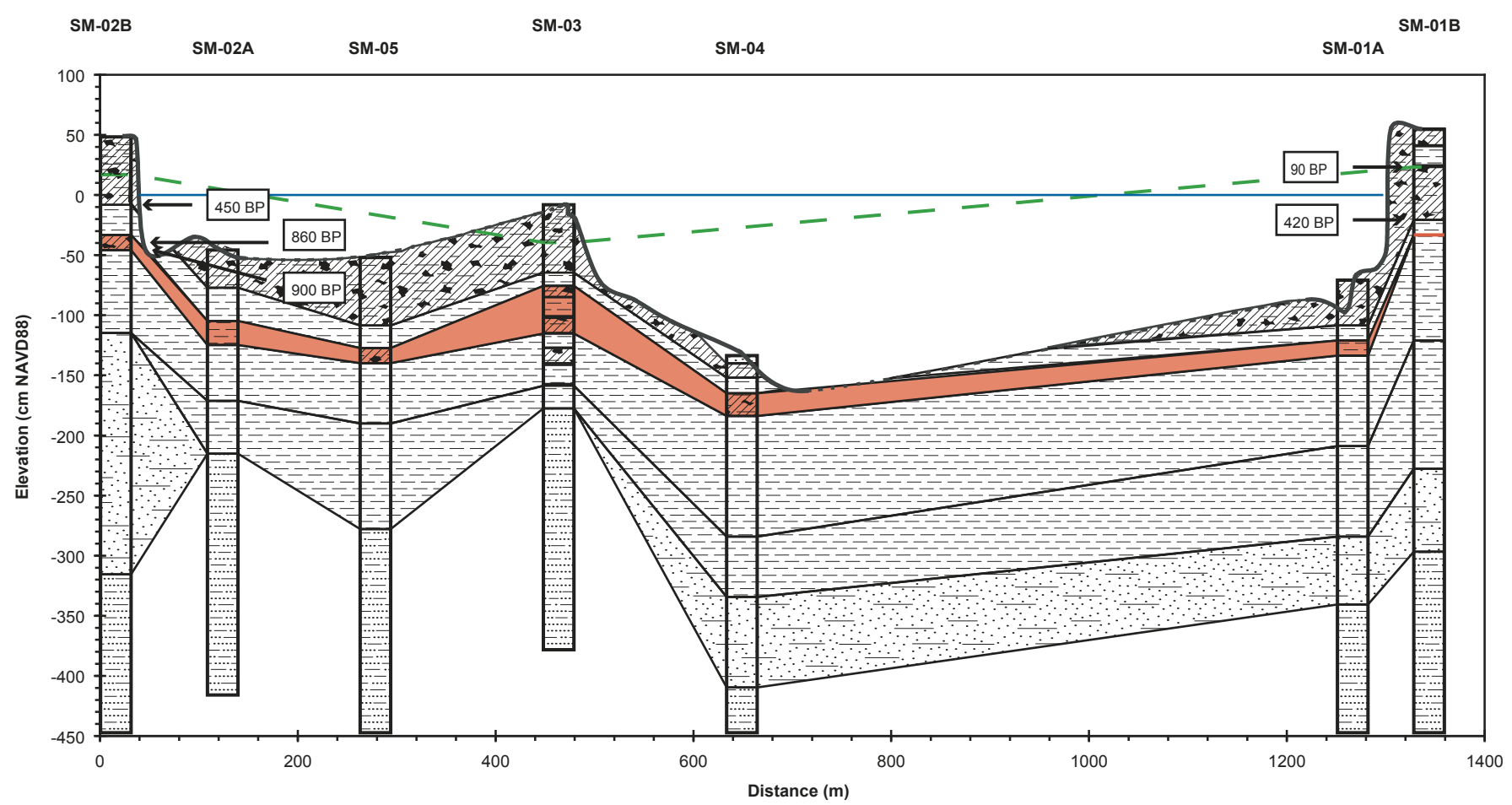

Figure 16. Combined bathymetric profile and stratigraphic cross section for marsh and open-water cores illustrate the magnitude of subsidence and wetland erosion (in $\mathrm{cm}$ ) at the Bully Camp area. Dashed green line shows correlation of the muddy recent marsh sediments. Locations shown in Figure 15, 200x vertical exaggeration.

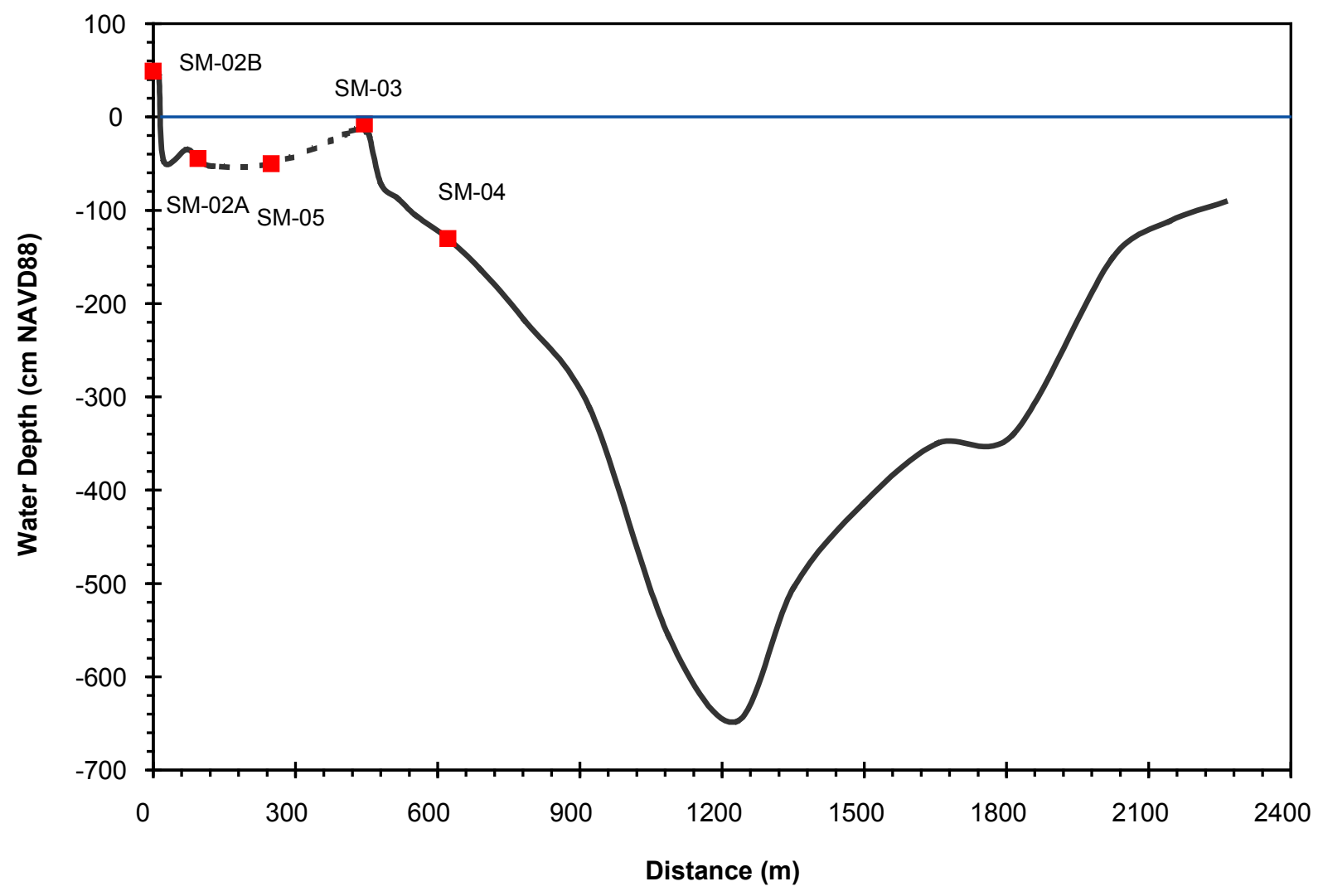

Figure 17. Bathymetric profile at Bully Camp extending east of the coring sites. Location shown in Figure 15. 
of Bayou Terrebonne (Bay St. Elaine and DeLarge), the first and last marshes are well developed, the first marsh peat is as thick or thicker than the last marsh peat, and the change from interdistributary mud to peat is distinct and not obscured by thin interbeds of mud and organic-rich mud. East of Bayou Terrebonne (Madison Bay, Pointe au Chien, and Bully Camp), the oldest organic-rich delta-plain deposits, which include the first marsh, consist of interbedded mud, muddy peat, and thin peat. In contrast, the last marsh deposits consist of a moderately thick continuous peat that grades stratigraphically upward into the recent (modern) marsh deposits.

Peat stratigraphy from the interdistributary core sites (Bay St. Elaine, DeLarge, Pointe au Chien, and Bully Camp) generally shows good correlation of the organic-rich marsh sediments and the underlying massive mud. Bay St. Elaine has the thickest section of gray mud with live roots, representing the most recent saline-marsh deposits. Resuspension of mud from nearby sources, including Lake Pelto and Terrebonne Bay, resulted in recent influx of clastic sediments and marsh aggradation at Bay St. Elaine, which has partly compensated for rapid subsidence. At Bay St. Elaine, the first and last peat intervals are comparable in thickness, and they are separated by muddy peat and mud, which suggests deposition in a broken-marsh setting. At DeLarge, the first peat is thicker than the last peat. The two peats are separated by mud with little organic content, which suggests the mud was deposited in an open-water setting. At Pointe au Chien, the two peat intervals are comparable in thickness and separated by mud with some organic material, also suggesting deposition in a more openwater setting. At Bully Camp, the first marsh peat is thin and poorly developed compared to the last marsh peat. Where both peats are present, they are separated by mud and organic-rich mud, which suggests deposition in a broken-marsh setting. At all four interdistributary sites, the organic-rich marsh sediments are about $110 \mathrm{~cm}$ thick. The Madison Bay coring site is on the flank of Bayou Terrebonne (Fig. 1), a major distributary of the Bayou Lafourche fluvial system. At Madison Bay, the first marsh is thin, poorly-developed, and interbedded with organicrich mud and muddy peat. In contrast, a thick, well-developed peat that is much thicker than at the other site represents the last marsh. Together the organic-rich deposits at Madison Bay are as much as $200 \mathrm{~cm}$ thick. This suggests that the youngest marsh deposits are thicker along the distributary flanks than at the interdistributary sites.

Radiocarbon ages of peats from the vibracores are generally consistent with the history of delta-plain progradation and abandonment presented by Penland and others (1988). The first marsh at DeLarge was established by 1,000 BP as active delta sedimentation switched from the Bayou du Large subdelta to Bayou Terrebonne (Fig. 1). Termination of the first marsh, about $850 \mathrm{BP}$, may have resulted from an influx of muddy sediment associated with progradation of the Bayou Grand Caillou distributary. The last marsh at DeLarge became established about $500 \mathrm{BP}$, toward the end of active delta building associated with Bayou Grand Caillou. The first marsh at Bay St. Elaine was initiated about 800 to 850 BP and aggraded primarily during the period that the Bayou Grand Caillou subdelta was prograding. Greater thickness of the first marsh at Bay St. Elaine compared to the other coring sites likely indicates a longer duration of delta-plain deposition and greater seaward progradation of the Bayou Grand Caillou lobe. The last marsh at Bay St. Elaine became established about $200 \mathrm{BP}$, which was later than at any other site. The first marsh at Madison Bay was established by approximately 950 BP, during active progradation of the Bayou Terrebonne subdelta, and the last marsh became established about $650 \mathrm{BP}$, shortly after delta sedimentation switched to Bayou Lafourche. The last marsh was initiated much earlier at Madison Bay on the flank of Bayou Terrebonne than at any other site. At Pointe au Chien and Bully Camp, the first marsh was established about 900 to $950 \mathrm{BP}$, toward the end of active progradation of Bayou Terrebonne, and the last marsh became established between about 300 to $450 \mathrm{BP}$ toward the end of Bayou Lafourche progradation. At all coring sites, accumulation of organic sediments associated with the first marsh lasted less than 200 years, except at Bay St. Elaine, where the first marsh persisted for 400 to 450 years.

McBride and others (1990) did not differentiate among different marsh deposits of the Bayou Grand Caillou subdelta; therefore, it is not possible to relate the number and thicknesses of peats between Bayou Grand Caillou and Bayou Lafourche. Kosters (1989), however, described a three-stage history of peat accumulation in the Barataria Basin, east of Bayou Lafourche. Judging from figures presented by Kosters (1989), it appears that the interval of organic-rich sediments and individual peat beds are thicker in the interdistributary area of Barataria Basin compared to those in the TerrebonneLafourche Basin.

\section{Subsurface Resource Extraction}

\section{Fluid Production near Coring Sites}

The Bay St. Elaine coring site is on the extreme southwestern flank of the area of hydrocarbon production (Figs. 2 and 18). At Bay St. Elaine, hydrocarbons are trapped on the flanks of a shallow piercement salt dome primarily by sand truncation and faults (Schneider, 1959). Approximately 540 wells were drilled in the field and more than 370 wells produced from 54 different Pliocene to late Miocene reservoirs at depths ranging from 1200 to $4600 \mathrm{~m}$ (Weitz, 1987). The crest of the salt dome, which is only about $200 \mathrm{~m}$ below the surface (Waguespack, 1983), is barren of hydrocarbons. The Bay St. Elaine field was discovered in 1929, but hydrocarbon production was not volumetrically significant until rapid 
development occurred between the 1950s and early 1970s (Fig. 19). Initially, oil was the primary fluid produced; gas production rapidly increased during the 1960s and peaked around 1970. Overall peak fluid production occurred between 1960 and 1980 (Fig. 19). Cumulative production at Bay St. Elaine through 2002 was 177 million bbls of oil, 942 Bcf of gas, and 155 million bbls of water.

The wetland-loss hotspot at Madison Bay is surrounded by wells extracting hydrocarbons from deep subsurface reservoirs. Lapeyrouse and Bay Baptiste (Fig. 2) are the productive fields closest to Madison Bay. Both fields produce from multiple reservoirs where hydrocarbons are trapped in rollover structures on the downthrown sides of major growth faults (Sticker, 1979; Piaggio, 1961). The deep subsurface fault controlling production at Lapeyrouse is a spur to the Golden Meadow Fault zone (Kuecher, 1994), whereas Bay Baptiste production is upthrown on this fault segment. Subsurface fluid-extraction rates at both fields were low to moderate in the 1940s and 1950s, but annual production accelerated in the 1960s and peaked in the early 1970s (Fig. 20, Morton and others, 2002). By 2002, the combined fluid production from both fields exceeded 770 Bcf of gas, 17 million bbls of oil, and 51 million bbls of water. This large-volume fluid production was accompanied by rapid reductions in formation pressure that typically dropped as much as 4,000 to 5,000 psi in normally pressured reservoirs (Morton and others, 2002).

Wetland loss in the DeLarge area is extensive and does not coincide directly with the limits of fluid production from the nearby DeLarge and Bayou Rambio fields (Fig. 2). Rates of oil-and-gas production from the DeLarge field and adjacent Bayou Rambio field peaked between 1965 and1980 (Fig. 21). The combined cumulative production through 2002 from both fields was 2.4 million bbls of oil, $198 \mathrm{Bcf}$ of gas, and 15.7 million bbls of water.

Patterns of wetland loss in the Pointe au Chien area do not coincide with the projected extent of any single oil-andgas field, but the area of wetland loss is surrounded by the Bayou Jean la Croix, Lirette, and Montegut fields (Fig. 2). Initial discovery of gas in the 1920s at Lirette was attributed to surface seeps, whereas deep hydrocarbons at Lirette were discovered in 1937 (Troutman, 1956) and at Montegut in 1957 (Silvernail, 1967). These fields produce from rollover anticline structures associated with a family of growth faults (Piaggio, 1961; Lyons, 1982). Peak hydrocarbon production from these fields occurred between 1965 and 1980 (Fig. 22). The combined cumulative production through 2002 from
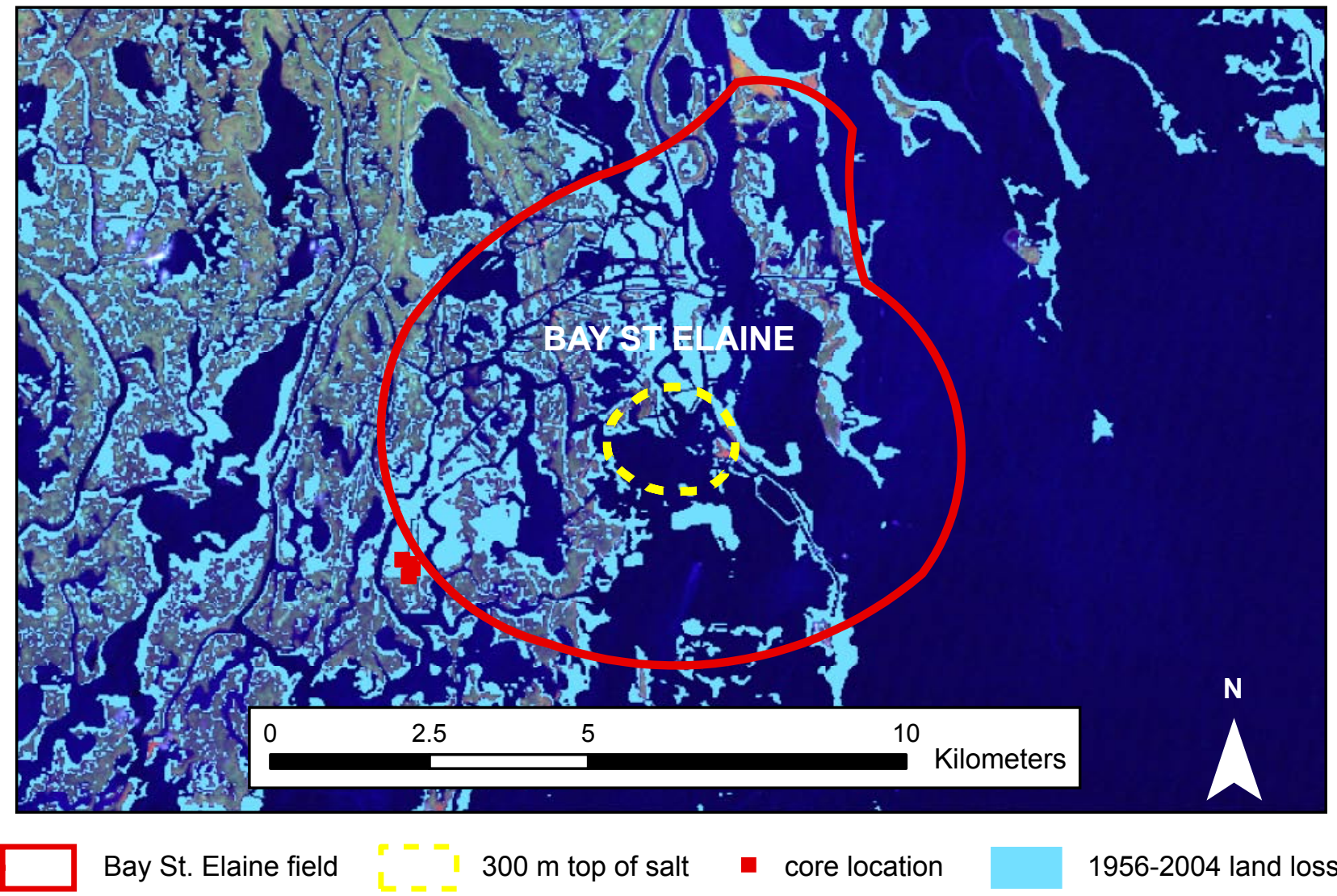

$300 \mathrm{~m}$ top of salt

- core location

1956-2004 land loss

Figure 18. Outline of Bay St. Elaine oil-and-gas field showing 300-m top-of-salt contour where sulfur mining was conducted. Landsat TM 5 image acquired Nov. 7, 2004 (RGB = 4,5,3). 


\section{Annual fluid production, Bay St. Elaine field, Louisiana}

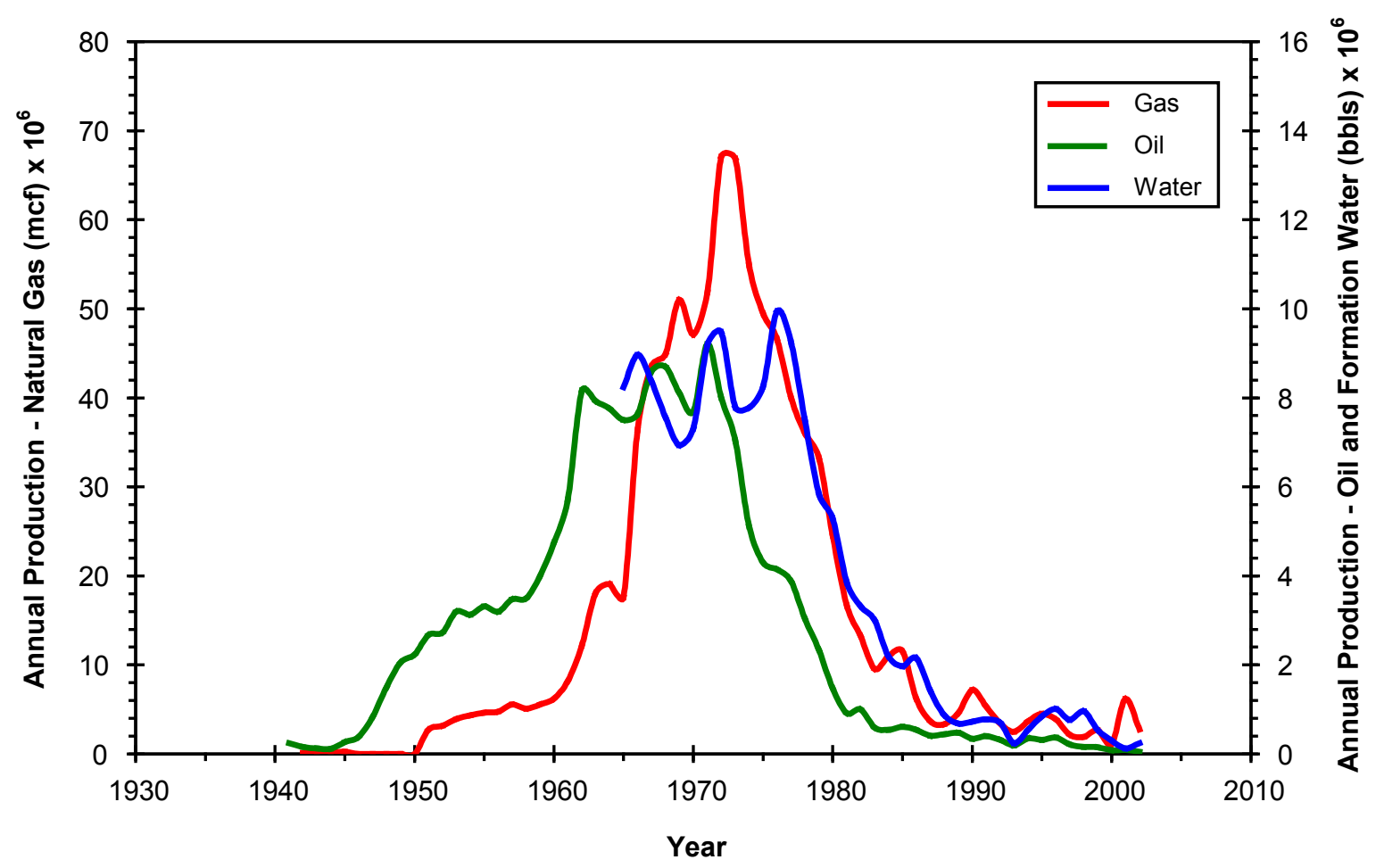

Figure 19. Annual fluid production through 2002 from the Bay St. Elaine field in Terrebonne Parish. One of more than 100 plots of oil-and-gas production from south Louisiana fields showing production volumes accelerated in the 1960s, peaked about 1970, went into rapid decline in the 1980s, and have been at low levels since the early 1990s. Data from the Louisiana Department of Natural Resources and the PI/Dwights PLUS database (IHS Energy, 2003).

the three fields was 35.2 million bbls of oil, 1.7 Tcf of gas, and 103 million bbls of water. Regional depressurization of subsurface reservoir strata may be a contributing factor to surface subsidence in this area. The projected surface trace of the Golden Meadow Fault extends through the southern zone of greatest wetland loss between Bayou Terrebonne and Bayou Pointe au Chien (Fig. 2), but spatially it does not appear to correlate with any limits to wetland loss. The projected surface trace of the Lake Hatch spur fault, however, approximates the northern boundary of extensive wetland loss.

Although wetland loss is extensive above the Bully Camp oil-and-gas field, patterns of wetland loss do not coincide with the locus of oil-and-gas production but are more extensive (Fig. 2). The Bully Camp field, which was discovered in 1942, produces from multiple Miocene and Pliocene reservoirs around the flanks of a shallow piercement salt dome (Troutman, 1956). Peak production from the Bully Camp field shows a temporal shift, with peak gas production between 1955 and1975, peak oil production between 1970 and 1980, and peak water production between 1976 and 1990 (Fig. 23). Cumulative fluid production through 2002 was 89 million bbls of oil, 231 Bcf of gas, and 76 million bbls of water. The surface trace of the Golden Meadow Fault essentially delineates the southern limit of local wetland loss in the Bully Camp area (Fig. 2). The trace of the Lake Hatch spur fault, if projected east along strike from Pointe au Chien, generally coincides with the northern extent of wetland loss.

\section{Sulfur Mining near Coring Sites}

The Frasch dissolution process was used extensively in the wetlands of south Louisiana to extract sulfur from the cap rock of shallow, piercement salt domes (Davis and Detro, 1992). Two sulfur mines (Bay St. Elaine and Bully Camp) operated in the Terrebonne-Lafourche drainage basins during the period of rapid delta-plain wetland loss. Both mines, constructed and operated by Freeport Sulphur Co., benefited from techniques developed at the Lake Grande Ecaille mine, which was constructed and began producing sulfur in 1933 . At the Grande Ecaille mine, subsidence induced by sulfur extraction was so great (as much as $10 \mathrm{~m}$ ) that mud pumped 
Annual fluid production, Madison Bay field area, Louisiana

Bay Baptiste and Lapeyrouse fields

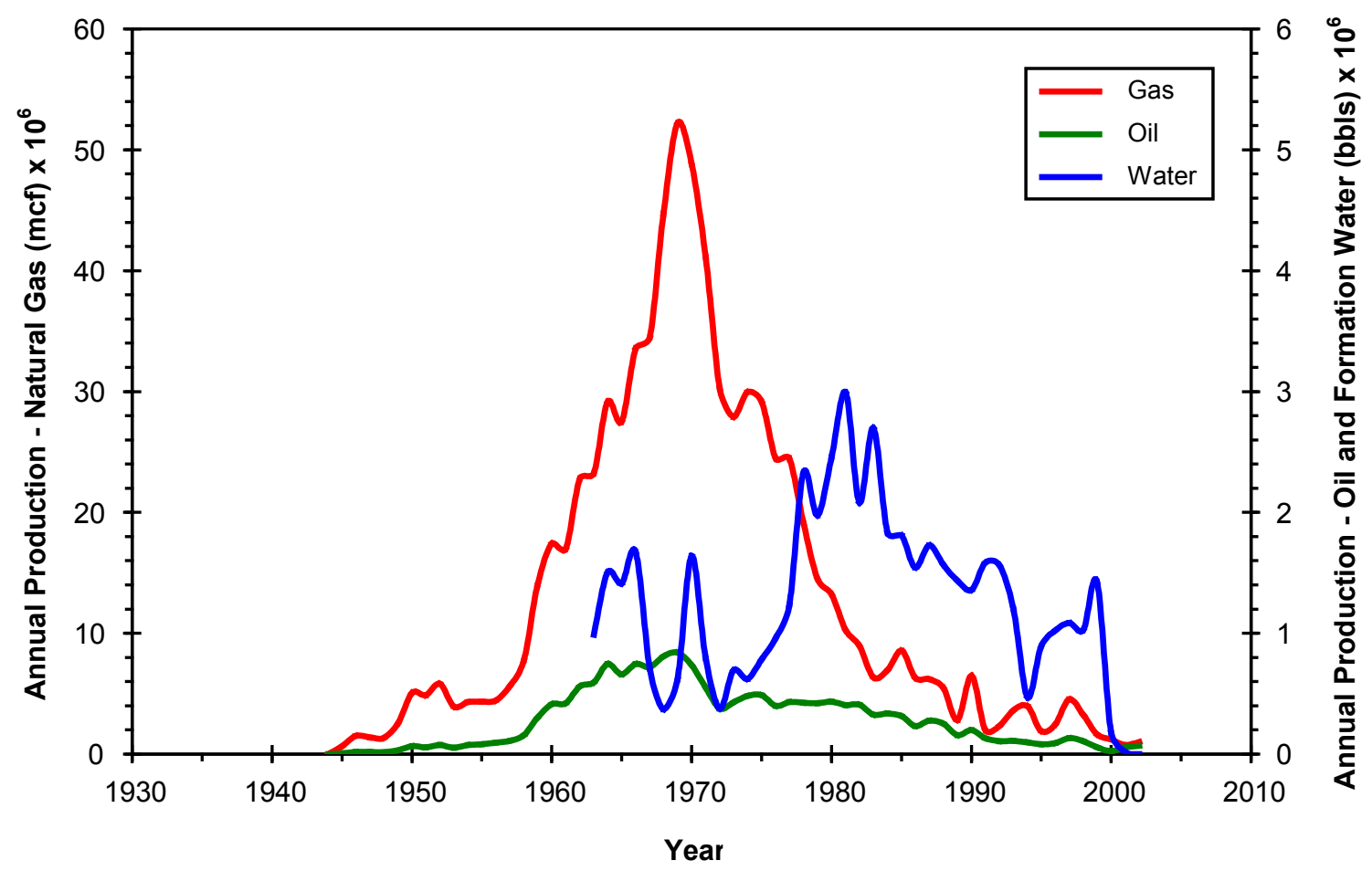

Figure 20. Annual fluid production through 2002 from the Lapeyrouse and Bay Baptiste fields in Terrebonne Parish. The most rapid subsidence and wetland loss at the nearby Madison Bay hotspot occurred between 1969 and 1974, shortly after peak production and pressure decline in the reservoirs of the Lapeyrouse field. Modified from Morton and others (2002). Data from the Louisiana Department of Natural Resources and the $\mathrm{PI} /$ Dwights PLUS database (IHS Energy, 2003).

by a dredge was necessary to maintain the mine-site elevation (Davis and Detro, 1992).

The sulfur-bearing cap rock at Bay St. Elaine is located about $200 \mathrm{~m}$ below the salt marsh (Waguespack, 1983). The Bay St. Elaine dome (Fig. 18) was an important sulfur producer between 1952 and 1959. During that 7-yr period, the floatingmine operation yielded slightly more than 1.1 million tons of sulfur (Wessel, 1994).

A top-of-salt map for the Bully Camp dome (Fig. 15) shows that the sulfur-bearing cap rock is less than $300 \mathrm{~m}$ below the marsh surface (Stipe and Spillers, 1960). Sulfur production from the Bully Camp mine began in 1968 and ended in 1978. During that 10 -yr period, slightly more than 1.7 million tons of sulfur were produced (Wessel, 1994).

\section{Geological and Historical Rates of Subsidence}

\section{Geological Subsidence Rates}

Rates of vertical sediment accumulation have been used as a proxy for subsidence rates based on the assumption that the accommodation space necessary for vertical sediment accumulation (aggradation) was provided by subsidence regardless of the specific process (crustal loading, sediment compaction, fault activation). For wetland sediments and static sea-level conditions, this assumption appears to be valid as a first approximation. The condition of constant sea level equivalent to modern sea level is not difficult to achieve for recent periods, such as decades or a few centuries, but would not be a reasonable assumption for periods encompassing several millennia. To avoid potential inaccuracies associated with eustatic fluctuations, only published subsidence rates for periods less than 5,000 years were included in the comparison 


\section{Annual fluid production, DeLarge study area, Louisiana}

Bayou Rambio and DeLarge fields

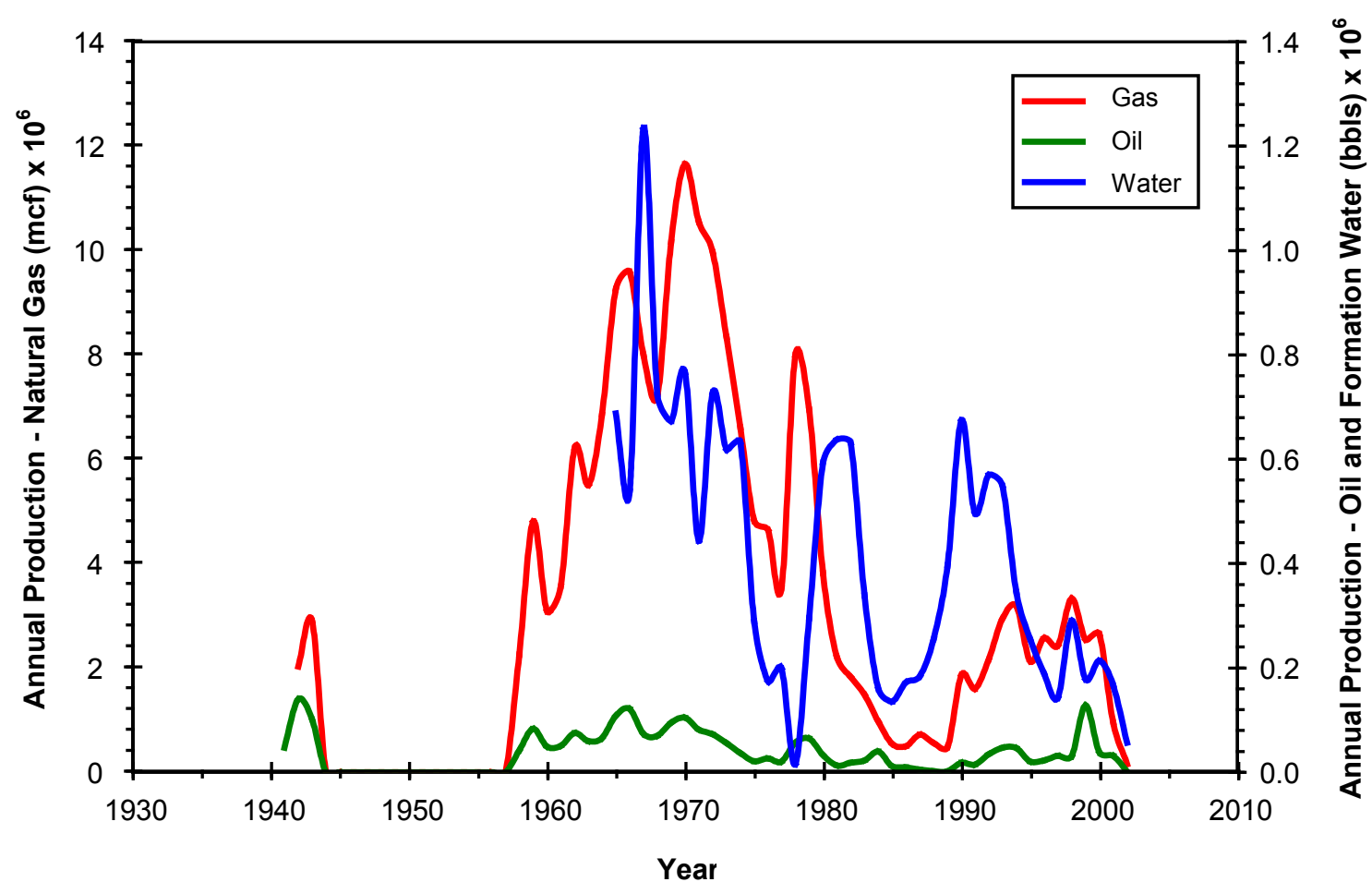

Figure 21. Annual fluid production through 2002 from the DeLarge and Bayou Rambio fields in Terrebonne Parish. Data from the Louisiana Department of Natural Resources and the PI/Dwights PLUS database (IHS Energy, 2003).

(Table 6). Geological rates of subsidence calculated for this study range from 0.5 to $4.4 \mathrm{~mm} / \mathrm{yr}$ (Table 5) and average about $2 \mathrm{~mm} / \mathrm{yr}$ (Table 6).

\section{Historical Subsidence Rates}

Historical changes in land elevation relative to a standard vertical datum, such as sea level, NGVD29, or NAVD88, can be measured directly from controlled benchmarks or inferred from long-period tide-gauge records (Holdahl and Morrison, 1974). Both of these methods have been used to approximate subsidence rates in south Louisiana (Penland and others, 1988; Morton and others, 2002). Recently, the National Geodetic Survey re-analyzed historical leveling data along Bayou Lafourche and Bayou Petit Caillou and calculated revised subsidence rates between 1965 and 1993. The spatial trends of the revised subsidence rates (Fig. 24) are identical to those presented by Morton and others (2002); however, they also allow comparison of subsidence rates for two periods (Fig. $24 \mathrm{~A})$. Within the context of generally increased subsidence in a seaward direction, highest rates of subsidence coincided locally with faults and producing oil-and-gas fields. Between the fields and faults, subsidence rates were lower. From 1965 to
1982, subsidence rates between Raceland and Leeville ranged from 1.6 to $12.0 \mathrm{~mm} / \mathrm{yr}$ and averaged about $7.6 \mathrm{~mm} / \mathrm{yr}$. From 1982 to 1993 , subsidence rates ranged from 8.2 to $18.9 \mathrm{~mm} / \mathrm{yr}$ and averaged about $12.1 \mathrm{~mm} / \mathrm{yr}$. Although subsidence rates accelerated between the two periods, the spatial order of higher and lower rates was maintained, indicating that subsidence is strongly controlled by subsurface geological processes.

\section{Comparison of Subsidence Rates}

Short-term historical rates of geological processes are commonly higher than the long-term average rates of those same processes, and subsidence rates are no exception. The important question to answer is whether the temporal differences are related to actual differences in the driving forces, or whether they are simply related to timing of the observations or sampling frequency. Some geological processes, such as fault slip or extreme-storm beach erosion, are intermittent, and their instantaneous rates may be very high, but the duration is short and the frequency of recurrence is low. These processes typically produce low long-term average rates of change. High instantaneous rates measured for these 


\section{Annual fluid production, Pointe au Chien study area}

Bayou Jean la Croix, Lirette, and Montegut fields

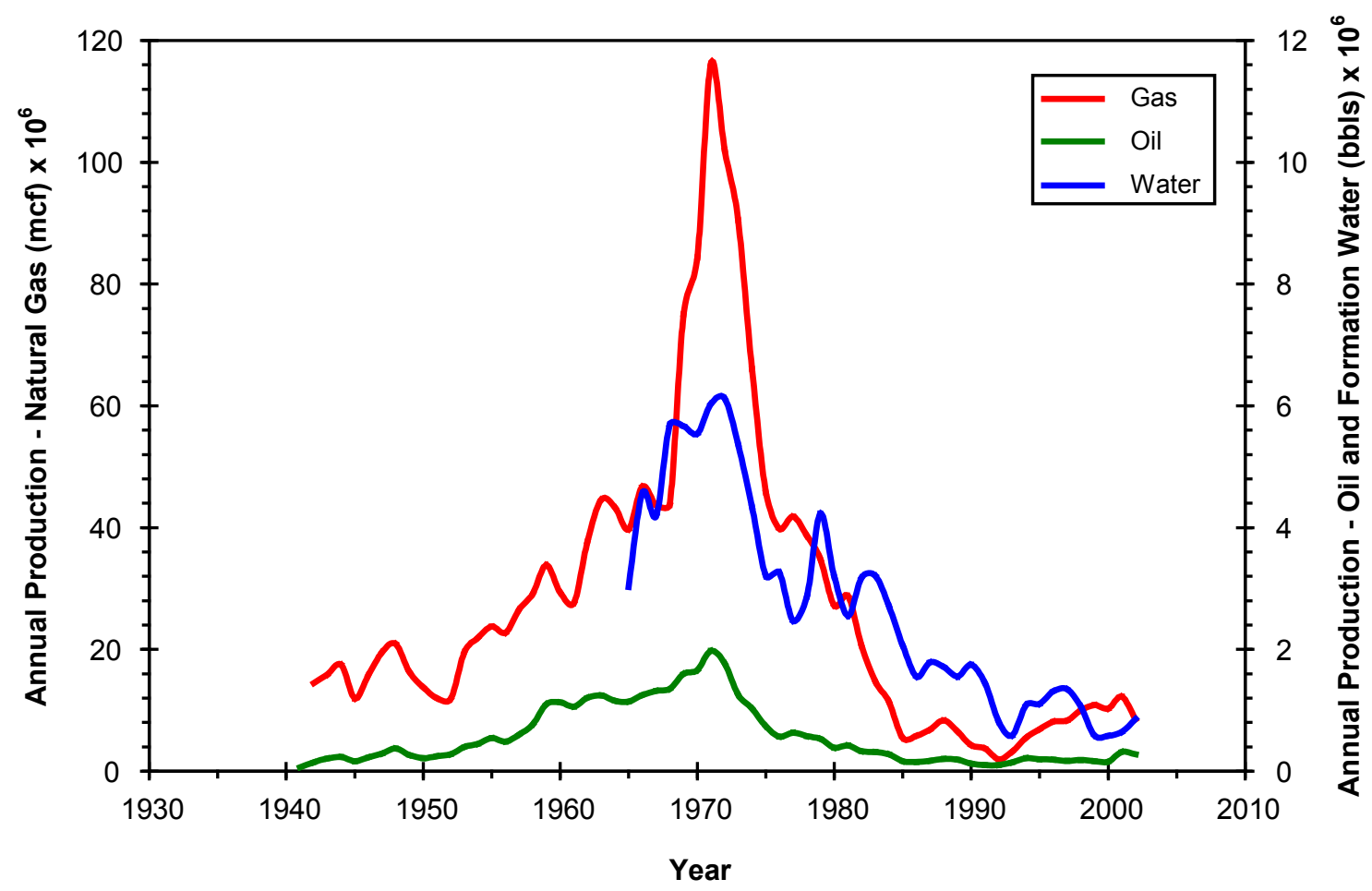

Figure 22. Annual fluid production through 2002 from the Bayou Jean la Croix, Lirette, and Montegut fields in Terrebonne Parish. Data from the Louisiana Department of Natural Resources and the PI/Dwights PLUS database (IHS Energy, 2003).

processes cannot be sustained indefinitely; therefore, those rates should not be extrapolated for predictive purposes. For example, if the historical rates of subsidence had persisted for the past 1,000 years, the Mississippi delta would have been deeply inundated long ago.

Historical subsidence rates are an order of magnitude higher than geological subsidence rates (compare Fig. 24 and Table 6). One explanation would be that natural faulting and subsidence are active at a time when monitoring is being conducted, and the methods of detection can resolve and measure the movement. Another explanation is that the rates actually are much higher than normally would be expected because subsidence and/or fault activation have been induced by subsurface-resource extraction.

Whether the high rates of historical subsidence and associated wetland loss are natural or induced is still somewhat controversial. Gagliano and others (2003) concluded that historical subsidence and wetland losses in south Louisiana were caused naturally by sediment loading, salt evacuation, and gravity gliding. All of these processes are known to be responsible for the overall tectonic regime of the Gulf Coast Basin, but Gagliano and others (2003) presented no evidence to substantiate their claim that the recent timing (post1960s) and rates of subsidence south of New Orleans were attributable to natural salt migration and faulting. They also did not consider that (1) major decreases in formation pore pressure, such as those reported by Morton and others (2002) around hydrocarbon producing fields in south Louisiana, have the same effect as sediment loading, or that (2) changes in subsurface stress induced by fluid withdrawal are capable of accelerating movement of potentially active faults (Chan, 2005). Gagliano and others (2003) also argued that the 1964 Alaskan earthquake was largely responsible for the timing of fault reactivation in south Louisiana, again without presenting any scientific evidence of transitory changes in subsurface stress that would support their speculation. The 1964 Alaskan earthquake was not felt in Louisiana, although seiches were generated in water bodies by the passing surface wave (Stevenson and McCulloh, 2001). Perhaps more important is the fact that the massive wetland losses in the Terrebonne Basin (Figs. 3 and 25) were mostly initiated more than 5 years after the 1964 Alaskan earthquake. 
Annual fluid production, Bully Camp field, Louisiana

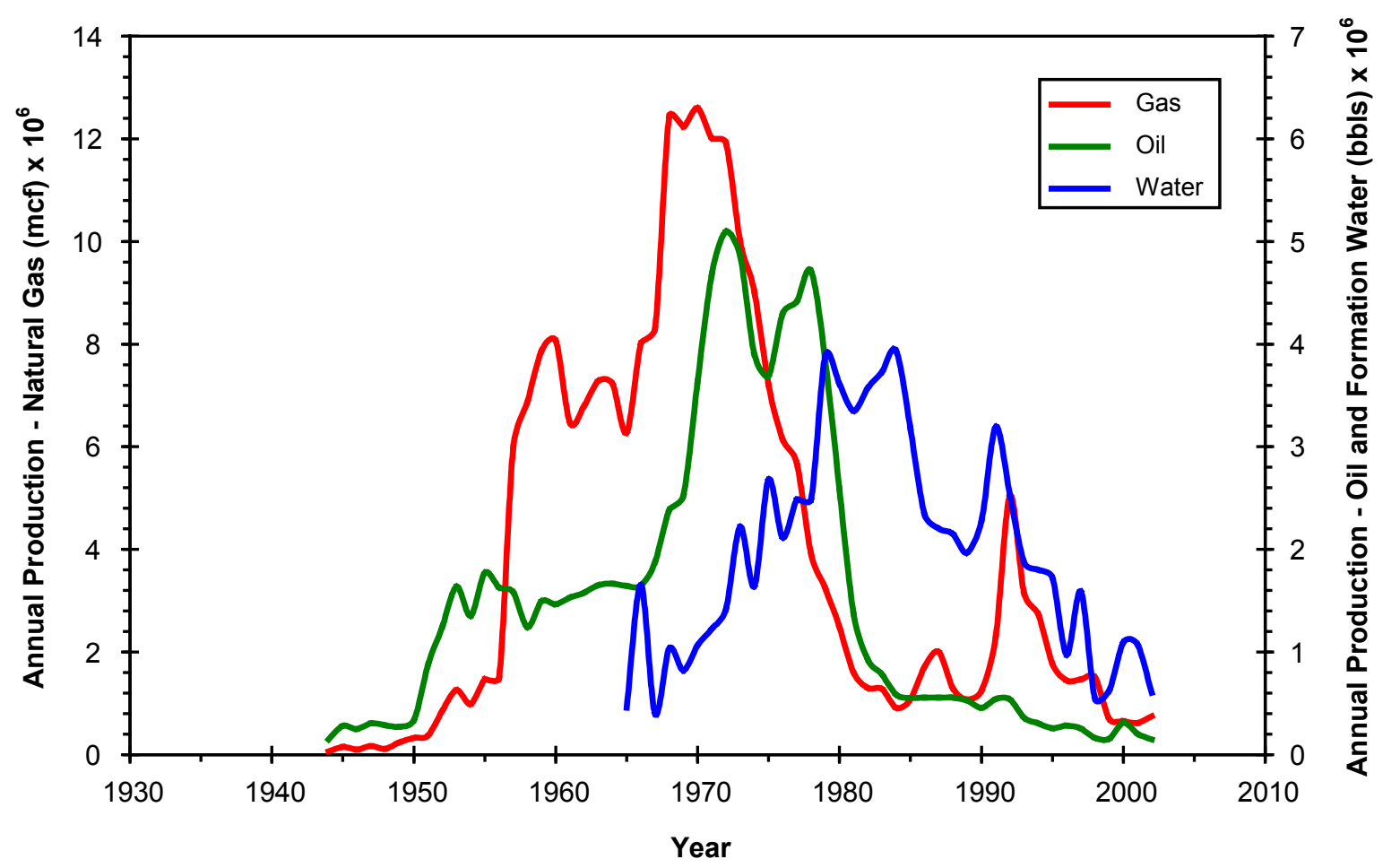

Figure 23. Annual fluid production through 2002 from the Bully Camp field in Lafourche Parish. Data from the Louisiana Department of Natural Resources and the PI/Dwights PLUS database (IHS Energy, 2003).

\section{Trends of Subsidence, Wetland Loss, and Resource Extraction}

Local patterns of wetland loss at Bay St. Elaine do not correlate directly with the subsurface position of the Bay St. Elaine (BSE) salt dome or locus of mineral production (sulfur, oil, and gas); however, this is probably because of original land-distribution patterns along the delta-plain margin (shoreline). The impact of sulfur mining on subsidence is uncertain at Bay St. Elaine because the floating mine was located in an area that was largely open water before extraction began. There has been extensive loss of shoreline wetlands and natural levees in the BSE area. Comparison of topographic maps indicates that rapid wetland loss within the 300-m top-of-salt contour on the BSE dome appears to have been between 1935 and 1957. This correlates temporally with sulfur production at the BSE mine. Peak oil-and-gas production from the BSE field occurred later, between 1965 and 1980.

The mining of solid material (sulfur and soluble cap rock) from the subsurface at relatively shallow depths undoubtedly contributed to rapid subsidence and conversion of wetlands to open water at Bully Camp. The deepest water measured at the Bully Camp site coincides with the intrusive cap rock and sulfur-mining operation.

\section{Status of Subsidence Prediction}

\section{Empirical Methods}

Numerical models used to predict subsidence caused by subsurface-fluid withdrawal are commonly inaccurate and therefore are not considered applicable for estimating future reductions in land elevation in south Louisiana. Even sophisticated subsidence-prediction models tend to underestimate observed subsidence (Chan, 2005), because the processes are still poorly understood and the fluid-production models typically focus only on depletion and pressure reduction in the primary reservoirs. In the absence of a reliable numerical model, qualitative and semi-quantitative predictions can be made on the basis of observations without regard for the underlying mechanisms. This empirical approach to prediction relies on subsidence measurements at benchmarks. Subsidence 
NGS subsidence rates, Raceland to Leeville, 1965-1993

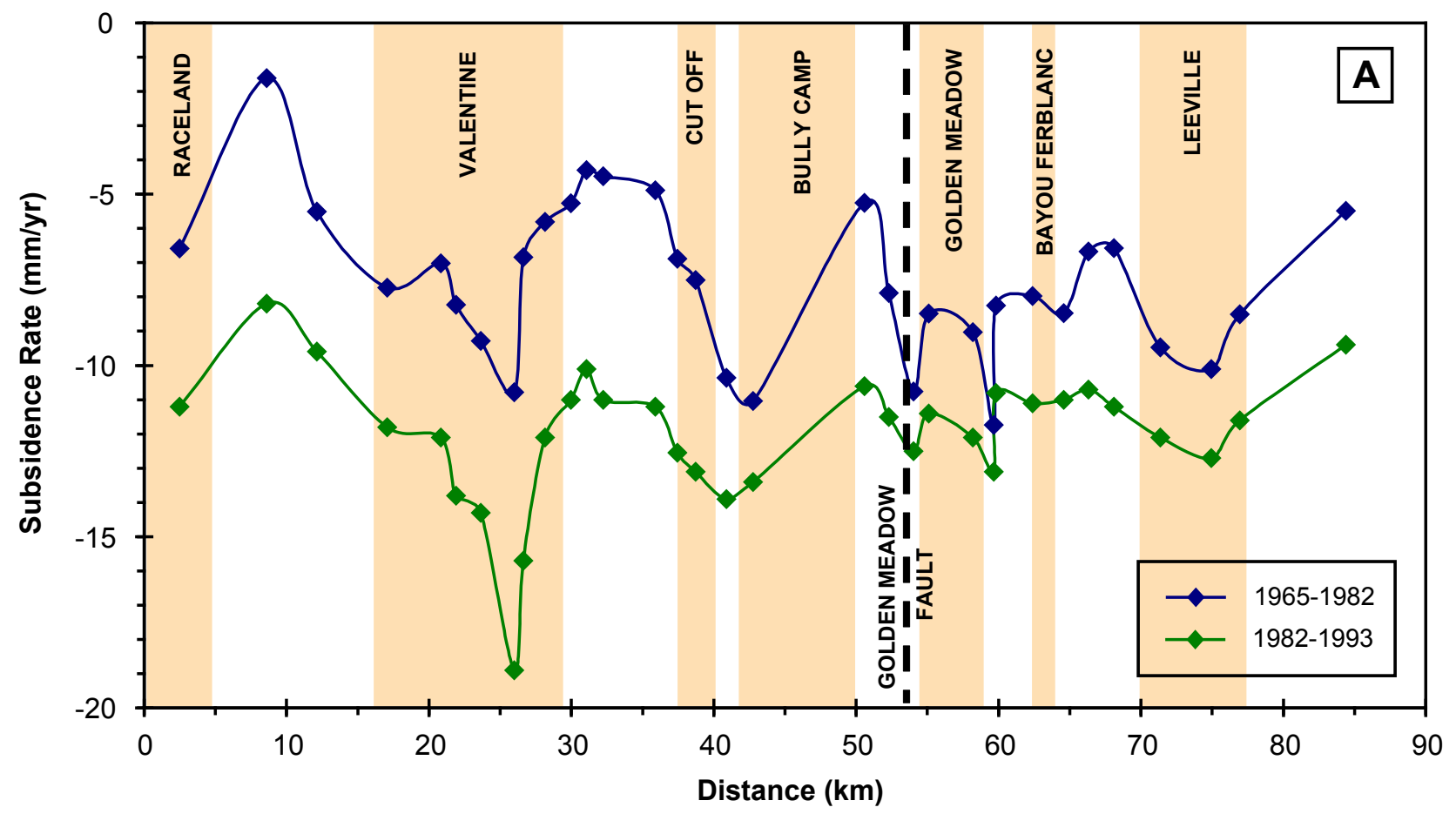

NGS subsidence rates, Houma to Cocodrie, 1966-1993

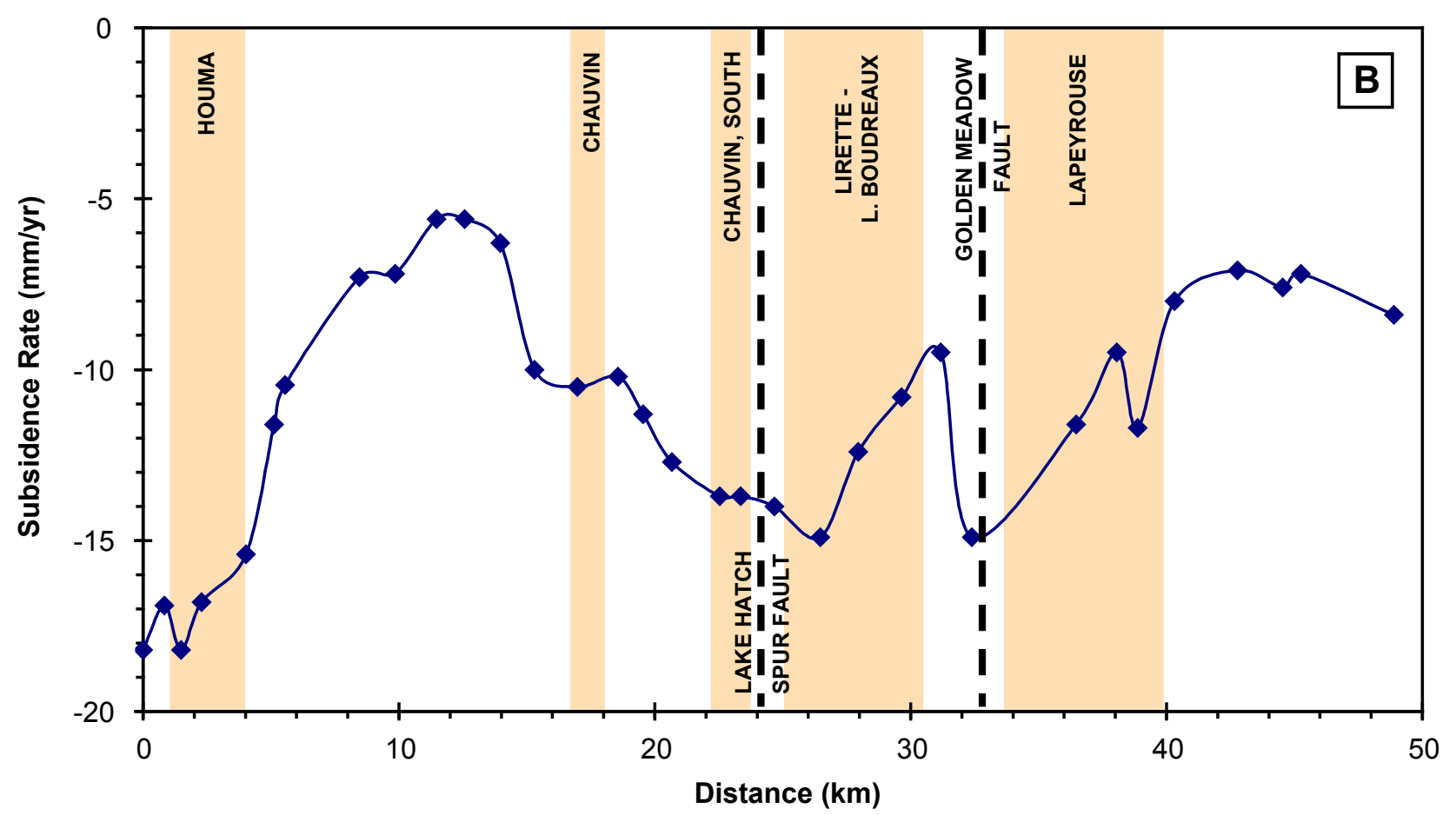

Figure 24. Plots of historical subsidence rates along (A) Bayou Lafourche and (B) Bayou Petit Caillou calculated by the National Geodetic Survey from re-leveling of benchmarks (Shinkle and Dokka, 2004). The plots show a close spatial correlation between highest subsidence rates, hydrocarbon-producing fields (delineated in tan), and the projected intersection of deep faults. They also show that subsidence rates accelerated between 1965-82 and 1982-93. Modified from Morton and others, 2002. Revised subsidence rates provided by Kurt Shinkle (NGS). 
Annual fluid production vs. rate of wetland loss, Louisiana delta plain

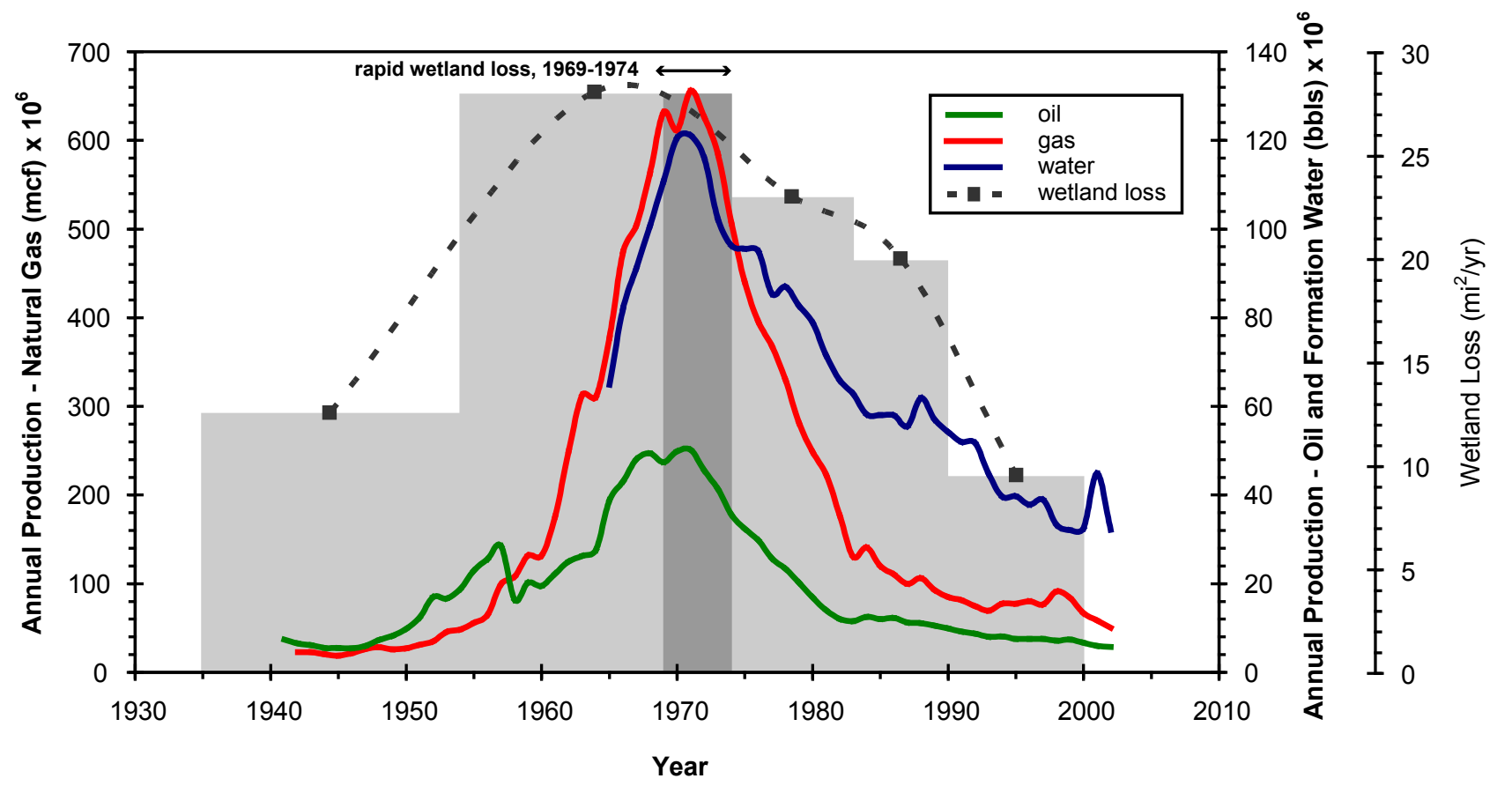

Figure 25. Composite histories of fluid production from oil-and-gas fields and wetland loss in south Louisiana. Production data from the Louisiana Department of Natural Resources and the PI/Dwights PLUS database (IHS Energy, 2003). Wetland loss values were determined by Britsch and Dunbar (1993) and John Barras (personal communication, 2005). These historical data, integrated across the delta plain, show close temporal and spatial correlations between rates of wetland loss and rates of fluid production.

magnitudes and trends derived from tide-gauge measurements are less reliable because water-level records contain decadal trends (Hicks, 1968; Douglas, 2001) that reflect external forces not related to land-elevation changes.

Predicting subsidence rates for south Louisiana currently is limited to inferences based on historical data, because rates since 1993 are not available and a NOAA GPS Continuously Operating Recording Station at Cocodrie has not been gathering data long enough to determine an extant rate. Two approaches to subsidence prediction are possible using the older data. One is a quantitative temporal analysis of subsidence rates to determine the average rates and trend for a subregion. At least two periods of subsidence measurements are necessary to establish the trend, and more than two, including the most recent period, are preferred. The subsidence trend refers to whether the rates have increased or decreased with time.

A second analytical approach is based on the spatial distribution of historical subsidence rates for a subregion. A map depicting average historical subsidence rates for the Terrebonne-Lafourche basins suggests three east-west zones of relatively high subsidence rates (Fig. 26). However, the validity of subsidence zones projected between the leveling lines cannot be tested because there are no comparable data in the interdistributary marshes between the levees. Furthermore, the highest historical subsidence rates coincide with the location of oil-and-gas fields; therefore, the area of influence may be more restricted than indicated by the map. One reason for concluding that the area of influence may follow regional structural trends is that rapid historical wetland subsidence extends well beyond the boundaries of producing fields (Fig. 2).

\section{By Analogy}

Another method of qualitatively predicting future subsidence trends is by analogy with a case study of induced subsidence where the geological conditions and driving forces are similar to those in south Louisiana. Regional subsidence induced by production of groundwater and hydrocarbons has been documented throughout the world where rates and volumes of fluid extraction have been high and sustained for prolonged periods (Poland and Davis, 1969; Martin and Serdengecti, 1984). A well-known example is the Houston-Galveston region in Texas where subsidence and fault reactivation were induced by industrial and municipal groundwater withdrawal (Galloway and others, 1999) and oil- 


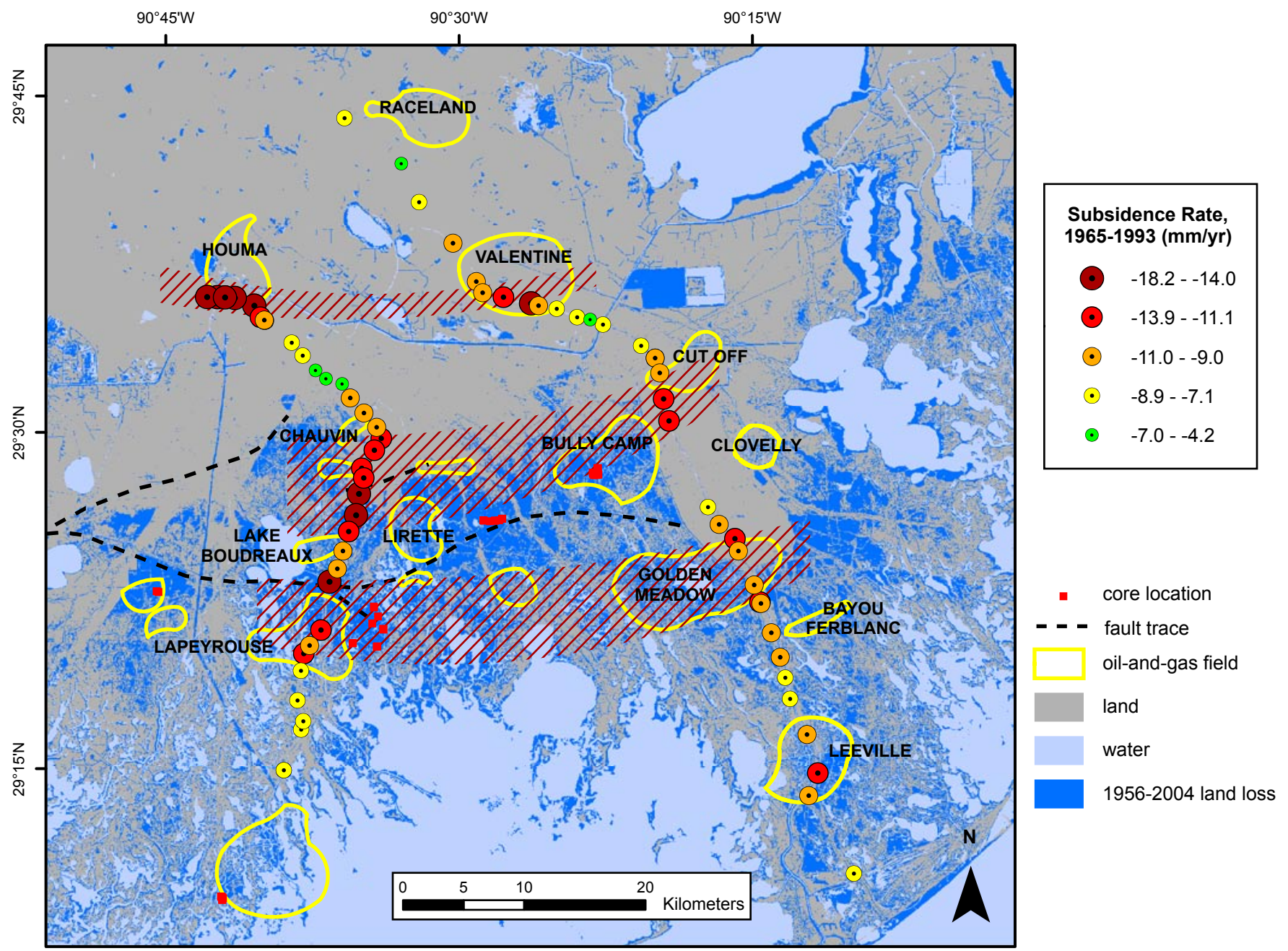

Figure 26. Map showing average subsidence rates between 1965 and 1993 in south Louisiana. Subsidence rates calculated by the National Geodetic Survey. Areas of highest average subsidence rates (>12 mm/yr; hatched pattern) correlate closely with locations of oil-and-gas fields. Lowest average subsidence rates are located between major producing fields. Hydrocarbonproducing fields shown in Figure 24 are labeled. The Nov. 7, 2004 Landsat TM 5 image was used for the land-water classification. Fault projection from Kuecher and others (2001).

and-gas production (Pratt and Johnson, 1926). This example of induced subsidence is applicable to the subsidence issues in south Louisiana because the Gulf Coast Basin framework geology and subsurface processes are similar, and long-term, large-volume fluid production histories are well established in both regions.

Induced subsidence was so severe around Houston that in 1975 the Texas legislature established a subsidence district and regulatory policies to discourage groundwater pumping and to encourage conversion to surface-water supplies. Extensometer measurements around Houston (Kasmarek and others, 1997), obtained as part of the subsidence-management program, show that where rates of groundwater withdrawal were greatly reduced, subsidence either slowed dramatically or stopped
(Fig. 27, Pasadena to Texas City), but where high rates of groundwater withdrawal continued, subsidence also continued at high rates (Fig. 27, Addicks).

The Houston-Galveston subsidence data clearly demonstrate that when the human activities inducing subsidence are stopped, then subsidence rates slow or return to the very slow background rates (few $\mathrm{mm} / \mathrm{yr}$ ) that are caused by natural geological processes within the sedimentary basin. Given the geological similarities between coastal Louisiana and coastal Texas, significant reductions in subsidence rates are expected in the Terrebonne-Lafourche Basins because the rates of subsurface-fluid withdrawal that are largely responsible for the rapid induced subsidence have markedly declined (Fig. 25). Moreover, whatever contribution fault reactivation may have 
made, fault movement likely has already relieved the stress differential created by subsurface pressure reductions, and the state of stress has returned to near-equilibrium conditions. If this is true, then additional subsidence related to fault reactivation would not be expected because the subsurface perturbation caused by peak fluid production has passed (Fig. 25).

\section{Conclusions and Implications}

Historical wetland losses in the Mississippi delta plain have been classified on the basis of morphology and interpreted physical processes (Penland and others, 2000a, 2000b). Wetland losses around the margins of interior water bodies were attributed to shoreline erosion based on the inferred erosional capability of storm waves and field observations of local marsh erosion. Results of our study indicate that most of the wetland losses around open-water bodies at the coring sites are due to subsidence. The imagery analysis and core pairs taken near the land-water interface clearly show that erosion is only a minor process converting wetlands to open water, and subsidence is largely responsible for the conversion. At most of the open-water sites that were continuous emergent marsh, extant water depths are greater than the thickness of the delta-plain marsh. This physical relation is clear evidence that wetland loss resulted from subsidence, because it is impossible to erode to those depths and still preserve some of the marsh deposits. Furthermore, the magnitudes and similarities of subsidence around the perimeters of water bodies that were former marshes is compelling evidence that the subsidence is not largely related to fault reactivation, because it is not geologically reasonable to infer a fault between each emergent marsh and open-water core pair. The similarities of subsidence magnitudes across the delta plain, regardless of position relative to a fault plane, are further evidence that recent subsidence is not locally fault controlled.

The lithologic and chronostratigraphic similarities of peat deposits from Bay St. Elaine, DeLarge, Pointe au Chien, and Bully Camp indicate that processes that influenced the organic accumulation and influx of clastic sediments operated over large portions of the delta plain, and not just locally. This implies that fault reactivation is not a likely mechanism to explain the alternation of peat and mud deposition several hundred years ago. Furthermore, there is no unequivocal evidence of a fault influencing the thickness or number of peat beds at any of the coring sites. This includes Bay St. Elaine where cores were deliberately taken across the marsh-water lineament that appears to be the surface expression of a fault (Fig. 6). The lack of preferential stratigraphic thickening on the inferred downthrown side of the fault (core BSE-03) cannot be used as evidence to discount movement of the fault. In fact, the fault may have moved recently, but there may not be evidence of recurrent motion in the recent geologic past that would result in stratigraphic expansion, which is typical of an active growth fault that moves frequently.

Emergent-marsh elevations, used as the standard for subsidence estimates, are significantly lower where subsidence has been greatest, such as at Madison Bay and in the marsh island remnants of Pointe au Chien and Bully Camp. Drowned

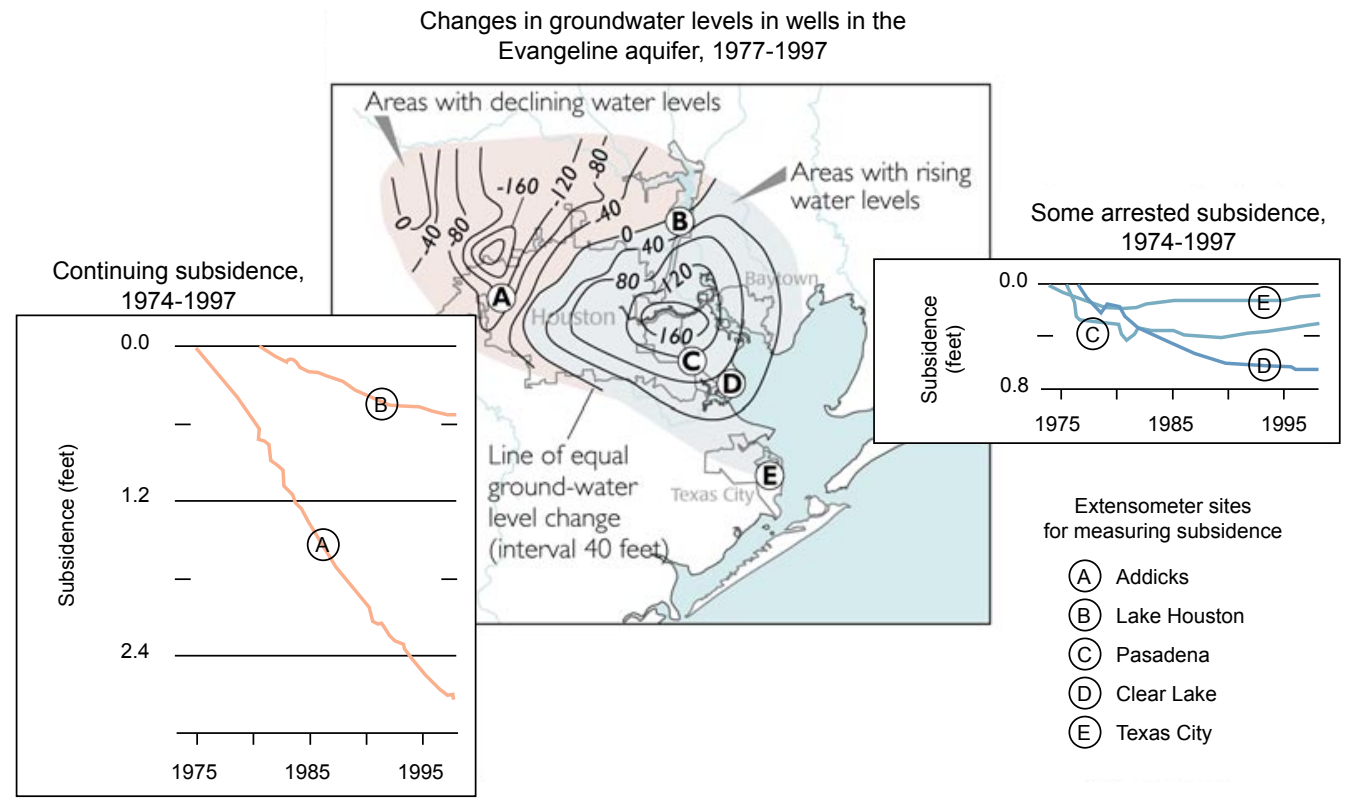

Figure 27. Land surface-subsidence trends in the Houston-Galveston area related to groundwater withdrawal. From Kasmarek and others (1997). 
marsh is an intermediate stage in the progression from emergent wetlands to open water. Imagery analysis identified patterns of submergence, including water-body enlargement, marsh breakup, and more uniform drowning of large sections of marsh. The drowned-marsh history confirms that subsidence initially was the primary process responsible for interior wetland loss and not erosion. Subsequent erosion of the former marsh sediments at open-water sites was greatest at Madison Bay than at other areas.

The types of core data and imagery used by Gagliano and others (2003) and Morton and others $(2002,2003)$ are similar, and yet their interpretations with regard to past and future subsidence and wetland loss are quite different. These differences are not academic, because they have profound implications with regard to predicting future subsidence and its impact on coastal-restoration projects. Gagliano and others (2003) attributed the historical subsidence and wetland loss to natural processes deep within the Gulf Coast Basin that are random and unpredictable as to future occurrences. In contrast, Morton and others $(2002,2003)$ concluded that the historical subsidence and wetland loss primarily were induced by fluid withdrawal, and therefore the future impacts are qualitatively predictable. Results from this study confirm that the most likely explanation for historical wetland losses in south-central Louisiana is regional subsidence and local fault reactivation induced by hydrocarbon production.

\section{Future Directions}

The results of this study give guidance to future research directions and the development of datasets that could facilitate resource-management decisions and coastal-restoration planning efforts in south Louisiana. The methods used to quantify land-water changes offer a relatively inexpensive way of efficiently monitoring the status of land and water areas by using satellite imagery that is collected frequently. Continued generation of data for land-water changes from satellite images and comparison with water levels at the time of the imagery will improve quantification of the rates of wetland loss and the variability of land-water changes that can be explained by water-level fluctuations. Although Landsat images do not have the high spatial resolution of most aerial photographs, the ability to evaluate significant land-water changes rapidly and accurately over large areas in a geospatially referenced environment justifies their use. In addition, the use of an automated filtering and classification process eliminates operator variability and provides reproducible results, an attribute that cannot be easily achieved with individuals responsible for classification and mapping from aerial photographs.

Introducing wet marsh as a third category into the landwater classification offers a powerful way of identifying high-risk areas of future wetland loss and may provide a predictive capability for marsh management and wetland-loss mitigation that previously was unrecognized. The submergedmarsh analysis would be enhanced by having precise elevations across the marsh that would better define heights of the healthy marsh surfaces, the fringing lower-marsh surfaces, and the frequently inundated submerged-marsh surfaces. Elevation profiles combined with the satellite imagery signatures could be used to characterize susceptibility to permanent flooding. Lidar surveys in wetlands, using current technology, probably are incapable of accurately depicting the subtle elevation differences that characterize these different marsh levels.

The conclusion that some interior water bodies are expanding as a result of subsidence rather than shoreline erosion needs to be tested systematically in the field. Shoreline erosion seems to be an intuitively correct explanation for water-body expansion where fetch and water-body orientation with respect to predominant wind directions are sufficient to generate erosive waves. This hypothesis can be tested easily by taking core pairs around the perimeters of some of the largest water bodies. Also, there are several wetland-loss mitigation sites where riprap was used to dampen wave energy, but the shoreline continued to retreat. Elevation profiles and cores taken landward of the riprap would offer a way of determining which processes were primarily responsible for the wetland loss and shoreline retreat. If shoreline erosion is not the primary cause of water-body expansion, then hard structures may not be an appropriate method of mitigating wetland loss at those sites.

Monitoring the rates and trends of delta-plain subsidence is necessary for accurately predicting future subsidence rates. Traditional- and GPS-leveling surveys, such as those conducted at benchmarks along Bayou Lafourche and the Mississippi River, are infrequent and expensive, so they probably will not be the source for frequently updating subsidence rates. The NOAA GPS Continuously Operating Recording Stations at Cocodrie and English Turn offer unparalleled opportunities to update subsidence rates frequently, but they only represent two sites within a vast delta plain where local subsidence rates are variable. The LDNR network of marsh-elevation sites could greatly expand the database of subsidence monitoring if the elevations are frequently updated.

Evaluating the relative vulnerability of coastal-restoration projects to potential subsidence is an objective of state officials who are charged with the responsibility of managing coastal resources. In the absence of a sophisticated numerical model for predicting subsidence, historical subsidence records can serve as indicators of regions of higher and lower risk. This approach becomes even more powerful when the subsurface processes causing subsidence are known and future trends can be predicted. 


\section{Acknowledgements}

We thank Phil McCartney, Mike Brown, and Mark Kulp (University of New Orleans Coastal Research Laboratory) for assistance in collecting the vibracores and water depths. Mark Kulp also provided supplementary descriptions and radiocarbon dates for cores collected by the Louisiana Geological Survey. Joyce Ober of the U.S. Geological Survey Minerals team provided cumulative sulfur production for mines operating in Louisiana. Kurt Shinkle of the National Geodetic Survey calculated subsidence rates at benchmarks along Bayou Lafourche and Bayou Petit Caillou. Julie Bernier prepared the final illustrations and Betsy Boynton prepared the report layout. Scientific and editorial reviews were provided by Mark Kulp and Kevin Kroeger.

\section{References}

Barras, J.A., Bourgeois, P.E., and Handley, L.R., 1994, Land loss in coastal Louisiana 1956-90: National Biological Survey, National Wetlands Research Center Open-File Report 94-01. $4 \mathrm{p}$.

Barras, J., Beville, S., Britsch, D., Hartley, S., Hawes, S., Johnston, J., Kemp, P., Kinler, O., Martucci, A., Porthouse, J., Reed, D., Roy, K., Sapkota, S., and Suhayda, J., 2003, Historical and projected coastal Louisiana land changes: 1978-2050: U.S. Geological Survey Open-File Report 03-334, 39 p.

Britsch, L.D., and Dunbar, J.B., 1993, Land-loss rates: Louisiana coastal plain: Journal of Coastal Research, v. 9, p. 324-338.

Chan, A.W.K., 2005, Production-induced reservoir compaction, permeability loss and land surface subsidence: unpublished Ph.D. dissertation, Stanford University, Stanford, California, $176 \mathrm{p}$.

Chmura, G.L., Aharon, P., Socki, R.A., and Abernathy, R., 1987, An inventory of ${ }^{13} \mathrm{C}$ abundance in coastal wetlands of Louisiana, USA: vegetation and sediments: Oecologia, v. 74, p. 264-271.

Davis, D.W. and Detro, R.A., 1992, Fire and brimstone: the history of melting Louisiana's sulphur: Louisiana Geological Survey Resource Information Series, no. 8, 114 p.

DeLaune, R.D., Smith, C.J., and Patrick, W.H., 1985, Land loss in coastal Louisiana: effect of sea level rise and marsh accretion: Louisiana State University Final Report, Board of Regents Research and Development Program.

Douglas, B.C., 2001, Sea level change in the era of the recording tide gauge, in Douglas, B.C., Kearney, M.S., and Leatherman, S.P., eds., Sea Level Rise; History and Consequences: International Geophysics Series, v. 75, p. 37-64.

Frazier, D.E., 1967, Recent deltaic deposits of the Mississippi River: their development and chronology: Transactions - Gulf Coast Association of Geological Societies, v. 17, p.287-315.

Gagliano, S.M., Kemp, E.B., Wicker, K.M., Wiltenmuth, K., and Sabate. R.W., 2003, Neo-tectonic framework of southeast Louisiana and applications to coastal restoration: Transactions - Gulf Coast Association of Geological Societies, v. 53, p. 262-272.

Galloway, D., Jones, D.R., and Ingerbritsen, S.E., 1999, Land subsidence in the United States: U. S. Geological Survey Circular 1182, $177 \mathrm{p}$. 
Hatton, R.S., DeLaune, R.D., and Patrick, W.H., Jr., 1983, Sedimentation, accretion, and subsidence in marshes of Barataria Basin, Louisiana; Limnology and Oceanography, v. 28, p. 494-502.

Hicks, S.D., 1968, Long-period variations in secular sea level trends: Shore and Beach, v. 36, p. 32-36.

Hodahl, S.R., and Morrison, N.L., 1974, Regional investigations of vertical crustal movements in the U.S., using precise relevelings and mareograph data: Tectonophysics, v. 23, p. 373-390.

IHS Energy Group, 2003, PI/Dwights Plus U.S. Production Data on CD: available from IHS Energy Group, 15 Inverness Way East, D205, Englewood, CO 80112.

Kasmarek, M.C., Coplin, L.S., and Santos, H.X., 1997, Water-level altitudes 1997, water-level changes 1977-1997, and 19961997, and compaction 1973-1996 in the Chicot and Evangeline aquifers, Houston-Galveston region, Texas: U.S. Geological Survey Open-File Report 97-181, 8 sheets.

Kosters, E.C., 1989, Organic-clastic facies relationships and chronostratigraphy of the Barataria interlobe basin, Mississippi delta plain: Journal of Sedimentary Petrology, v. 59, p. 98-113.

Kuecher, G.J., Roberts, H.H., Thompson, M.D., and Matthews, I., 2001, Evidence for active growth faulting in the Terrebonne delta plain, south Louisiana: implications for wetland loss and the vertical migration of petroleum: Environmental Geosciences, v. 8, p. 77-94.

Kuecher, G.J., 1994, Geologic framework and consolidation settlement potential of the Lafourche Delta, topstratum valley fill: Implications for wetland loss in Terrebonne and Lafourche Parishes, Louisiana: unpublished Ph.D. dissertation, Louisiana State University, Baton Rouge, 375 p.

Kulp, M.A., and Howell, P.D., 1998, Assessing the accuracy of Holocene subsidence rates in southern Louisiana as indicated by radiocarbon-dated peats: Geological Society of America, Abstracts with Programs, v. 30, p. 142.

Lyons, W.S., 1982, Subsurface geology and geopressured/geothermal resource evaluation of the Lirette-Chauvin-Lake Boudreaux area, Terrebonne Parish, Louisiana: unpublished M.S. thesis, University of Southwestern Louisiana, Lafayette, $125 \mathrm{p}$.

Martin, J.C., and Serdengecti, S., 1984, Subsidence over oil and gas fields, in Holzer, T.L., ed., Geological Society of America, Reviews in Engineering Geology, v. VI, p. 23-34.
McBride, R.A., Penland, S., and Mestayer, J.T., 1990, Facies architecture of the Bayou Grand Caillou area: an abandoned shallow water delta of the Mississippi River delta plain: Transactions - Gulf Coast Association of Geological Societies, v. 40, p. 575-583.

Morton, R.A., and White, W.A., 1997, Characteristics of and corrections for core shortening in unconsolidated sediments: Journal of Coastal Research, v. 13, p. 761-769.

Morton, R.A., Buster, N.A., and Krohn, M. D., 2002, Subsurface controls on historical subsidence rates and associated wetland loss in southcentral Louisiana: Transactions - Gulf Coast Association of Geological Societies, v. 52, p. 767-778.

Morton, R.A., Tiling, G., and Ferina, N.F., 2003, Causes of hotspot wetland loss in the Mississippi delta plain: Environmental Geosciences, v. 10. p. 71-80.

Penland, S., Ramsey, K.E., McBride, R.A., Mestayer, J.T., and Westphal, K.A., 1988, Relative sea-level rise and delta-plain development in the Terrebonne Parish region: Louisiana Geological Survey, Coastal Geology Technical Report No. 4, $121 \mathrm{p}$.

Penland, S., Wayne, L., Britsch, L.D., Williams, S.J., Beall, A.D., and Butterworth, V.C., 2000a, Geomorphic classification of coastal land loss between 1932 and 1990 in the Mississippi River delta plain, southeastern Louisiana: U.S. Geological Survey Open-File Report 00-417, 1 sheet.

Penland, S., Wayne, L., Britsch, L.D., Williams, S.J., Beall, A.D., and Butterworth, V.C., 2000b, Process classification of coastal land loss between 1932 and 1990 in the Mississippi River delta plain, southeastern Louisiana: U.S. Geological Survey Open-File Report 00-418, 1 sheet.

Piaggio, A.D., 1961, The Montegut-Lirette-Bay Baptiste structural complex: Terrebonne Parish, Louisiana: The Compass, $\mathrm{p}$. 157-171.

Poland, J.F. and Davis, G.H., 1969, Land subsidence due to withdrawal of fluids: Reviews in Engineering Geology, v. 2, p. 187-269.

Pratt, W.E., and Johnson, D.W., 1926, Local subsidence of the Goose Creek oil field: Journal of Geology, v. 34, p. 577-590.

Reed, D.J., ed., 1995, Status and trends of hydrologic modification, reduction in sediment availability, and habitat loss/ modification in the Barataria-Terrebonne estuarine system: Barataria-Terrebonne National Estuary Program Publication No. 20, 338 p. 
Roberts, H.H., Bailey, A., and Kuecher, G.J., 1994, Subsidence in the Mississippi River delta - Important influences of valley filling by cyclic deposition, primary consolidation phenomena, and early diagenesis: Transactions - Gulf Coast Association of Geological Societies, v. 44, p. 619-629.

Rybczk, J.M., and Cahoon, D.R., 2002, Estimating the potential for submergence for two wetlands in the Mississippi River delta: Estuaries, v. 25, p. 985-998.

Schneider, S.J., 1959, Bay Sainte Elaine oil field, southern Louisiana: American Association of Petroleum Geologists Bulletin, v. 43, p. $2470-2480$.

Shinkle, K.D., and Dokka, R.K., 2004, Rates of vertical displacement at benchmarks in the lower Mississippi Valley and the northern Gulf Coast: National Oceanic and Atmospheric Administration, Technical Report 50, $135 \mathrm{p}$.

Silvernail, J.D., 1967, Lirette and Montegut fields, in Braunstein, J., ed., Oil and Gas Fields of Southeast Louisiana, v. II: New Orleans Geological Society, p. 109-115.

Stevenson, D.A., and McCulloh, R.P., 2001, Earthquakes in Louisiana: Louisiana Geological Survey Public Information Series No. $7,8 \mathrm{p}$.

Sticker, E.E., 1979, Geology and reservoir analysis of the Lapeyrouse Field, Terrebonne parish, Louisiana: unpublished M.S. thesis, University of New Orleans, New Orleans, 67 p.

Stipe, J.C. and Spillers, J.P., eds., 1960, Salt domes of south Louisiana, Volume 2: New Orleans, New Orleans Geological Society, $107 \mathrm{p}$.

Troutman, A., 1956, The oil and gas fields of southeast Louisiana: Five Star Oil Report, Houston, p. 101-104.

Waugespack, S.J., ed., 1983, Salt domes of south Louisiana, v. 3: New Orleans Geological Society, 142 p.

Weitz, J.H., 1987, Bay St. Elaine field, in Conatser, W.E. and Fein, M.N., eds., Oil and Gas Fields of Southeast Louisiana, v. III supplement: New Orleans Geological Society, p. 1a-1e.

Wessel, G.R., 1994, Sulfur resources, in Carr, D.D., ed., Industrial Minerals and Rocks: Society for Mining, Metallurgy, and Exploration, Inc., Littleon, Colorado, p. 1011-1048.

Wicker, K.M., 1980, The Mississipi deltaic plain habitat mapping study: U.S. Fish and Wildlife Service, Office of Biological Services, FWS/PBS-79/07. 


\section{APPENDIX 1: CORE DESCRIPTIONS AND PHOTOGRAPHS}

Note: the core-naming convention used in the report body differs slightly from that recorded in the field and used in Appendix 1 core descriptions. The naming convention used in the core descriptions includes a year (and month, for Madison Bay) identifier, e.g., BSE 03-01 indicates core \#1 taken at Bay St. Elaine in 2003, and MB 04-02-01 indicates core $\# 1$ taken at Madison Bay, April, 2002. The abbreviated names used in the report body are BSE-01 and MB-01, respectively. 


\section{Core BSE 03-01}

Location: Bay St. Elaine, Terrebonne Parish, LA

Latitude N $29^{\circ} 09^{\prime} 04.2^{\prime \prime}$

Longitude W $90^{\circ} 42^{\prime} 55.2^{\prime \prime}$

Date cored 09/03/2003

Date described 12/03/2003

Water depth $90 \mathrm{~cm}$

Corrected (NAVD88) depth $35 \mathrm{~cm}$

Core length $499 \mathrm{~cm}$

Compaction $18 \mathrm{~cm}$

\section{$0-133 \mathrm{~cm} \quad$ Dark Olive-Gray Mud}

massive, slightly hydrous mud with small fibrous roots and plant fragments shell fragments at $34,48,84,93,112$, and $129 \mathrm{~cm}$

sharp basal contact

$133-150 \mathrm{~cm}$

\section{Black Peat}

fibrous root mat

$>90 \%$ organics

gradational basal contact

sample BSE-01-146/147: conventional age $820 \pm 40 \mathrm{BP}, \delta^{13} \mathrm{C}-25.6 \%$ o

$150-196 \mathrm{~cm}$

\section{Olive-Gray Mud}

massive mud with fibrous roots

large organic clast at $169.5 \mathrm{~cm}$

deformed basal contact

$196-256 \mathrm{~cm}$

\section{Dark Greenish-Gray Mud}

mostly massive mud

some burrowing from $200-210 \mathrm{~cm}$

tan horizons at 210, 216, 238, and $251 \mathrm{~cm}$

some parallel laminations are slightly deformed

gradational basal contact

$256-308 \mathrm{~cm}$

Dark Greenish-Gray Silty Sand

massive silty sand

sharp basal contact

$308-341 \mathrm{~cm}$

\section{Medium Gray Mud and Sand}

parallel-laminated mud interbedded with very fine-grained sand

average thickness of sandy strata $\sim 6 \mathrm{~cm}$

sharp basal contact

$341-499 \mathrm{~cm}$

\section{Medium Gray Mud and Sand}

faintly laminated mud interbedded with very fine-grained sand

average thickness of sandy strata $2-4 \mathrm{~cm}$ 


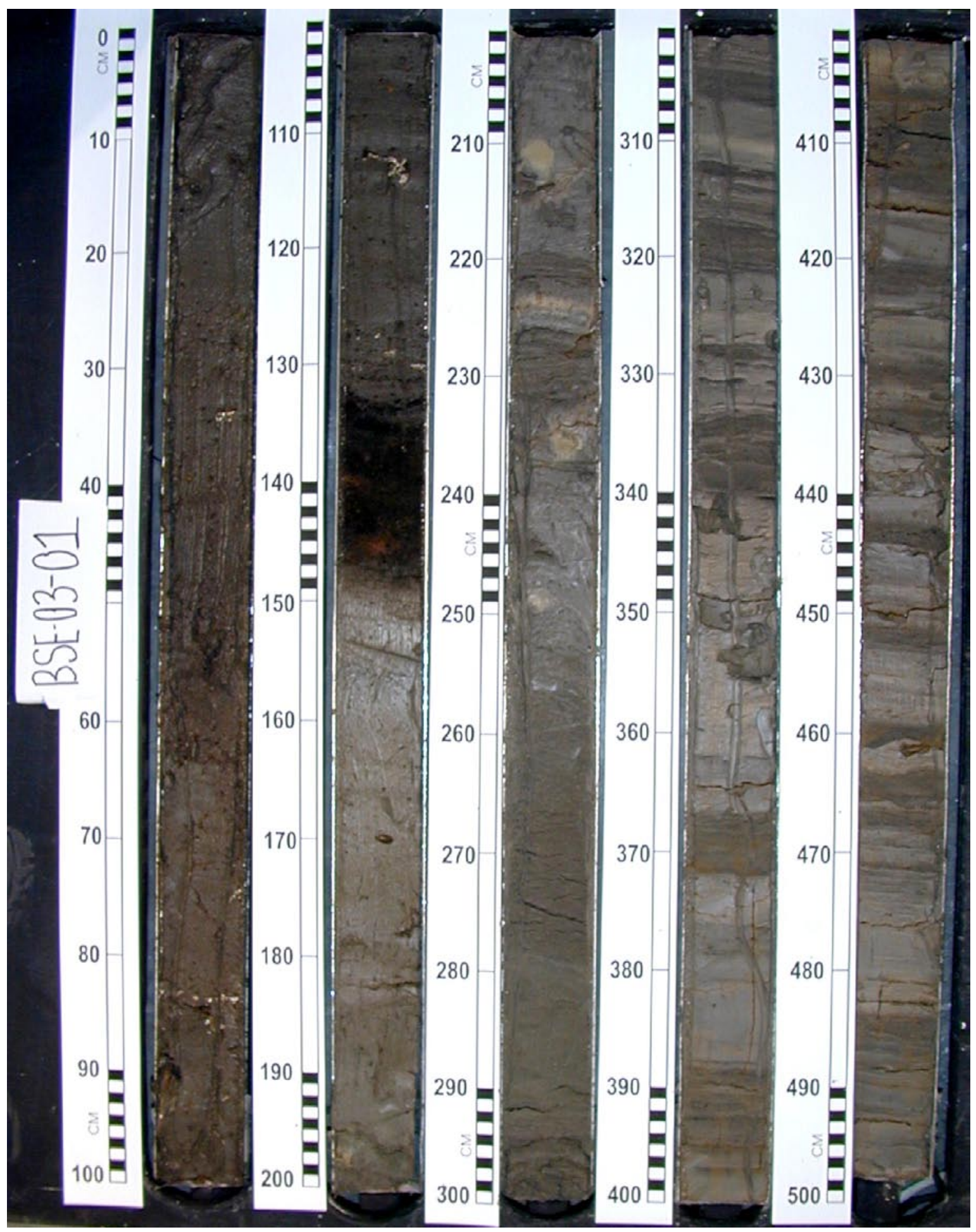




\section{Core BSE 03-02}

Location: Bay St. Elaine, Terrebonne Parish, LA

Latitude N 29०09'00.9"

Longitude W $90^{\circ} 42^{\prime}$ 57.8'"

Date cored 09/03/2003

Date described 12/03/2003

Water depth $61 \mathrm{~cm}$

Corrected (NAVD88) depth $8 \mathrm{~cm}$

Core length $657 \mathrm{~cm}$

Compaction $57 \mathrm{~cm}$

$0-42 \mathrm{~cm} \quad$ Dark Olive-Gray Peat

root mat with small fibrous roots and some larger roots

$>90 \%$ organics

$42-72 \mathrm{~cm} \quad$ Dark Olive-Gray Mud and Peat

mud interbedded with peat

muddy strata $2-3 \mathrm{~cm}$ thick, with roots common

peat layers from 44-55 and 58-69 cm, > 90\% organics

deformed basal contact

$72-111 \mathrm{~cm} \quad$ Black Peat

root mat with very small fibrous roots

$>90 \%$ organic

sharp basal contact

sample BSE-02-073/074: conventional age $400 \pm 40 \mathrm{BP}, \delta^{13} \mathrm{C}-23.4 \%$ o

sample BSE-02-110/111: conventional age $850 \pm 40 \mathrm{BP}, \delta^{13} \mathrm{C}-26.6 \%$ 。

$111-154 \mathrm{~cm}$

Medium Gray Mud

massive mud with some organics

$154-200 \mathrm{~cm}$

Medium Gray Mud

massive mud

possible burrows and/or deformation

$200-248 \mathrm{~cm}$

Medium Gray Silty Sand

massive silty sand

some muddy laminations are slightly deformed

$248-310 \mathrm{~cm} \quad$ Medium Gray Mud and Sand

parallel-laminated mud interbedded with very fine-grained sand

slight deformation of laminae

sharp basal contact

$310-617 \mathrm{~cm}$

\section{Medium Gray Mud and Sand}

parallel-laminated mud interbedded with very fine- to fine-grained sand

average thickness of muddy strata $10-20 \mathrm{~cm}$ at top, decreasing to $5-10 \mathrm{~cm}$ below $400 \mathrm{~cm}$

average thickness of sandy strata $1-2 \mathrm{~cm}$

shell horizon with whole valves preserved at $615 \mathrm{~cm}$

$617-657 \mathrm{~cm} \quad$ Medium Gray Mud

faintly laminated mud

some very fine-grained sand stringers $<1 \mathrm{~cm}$ thick

possible burrows 

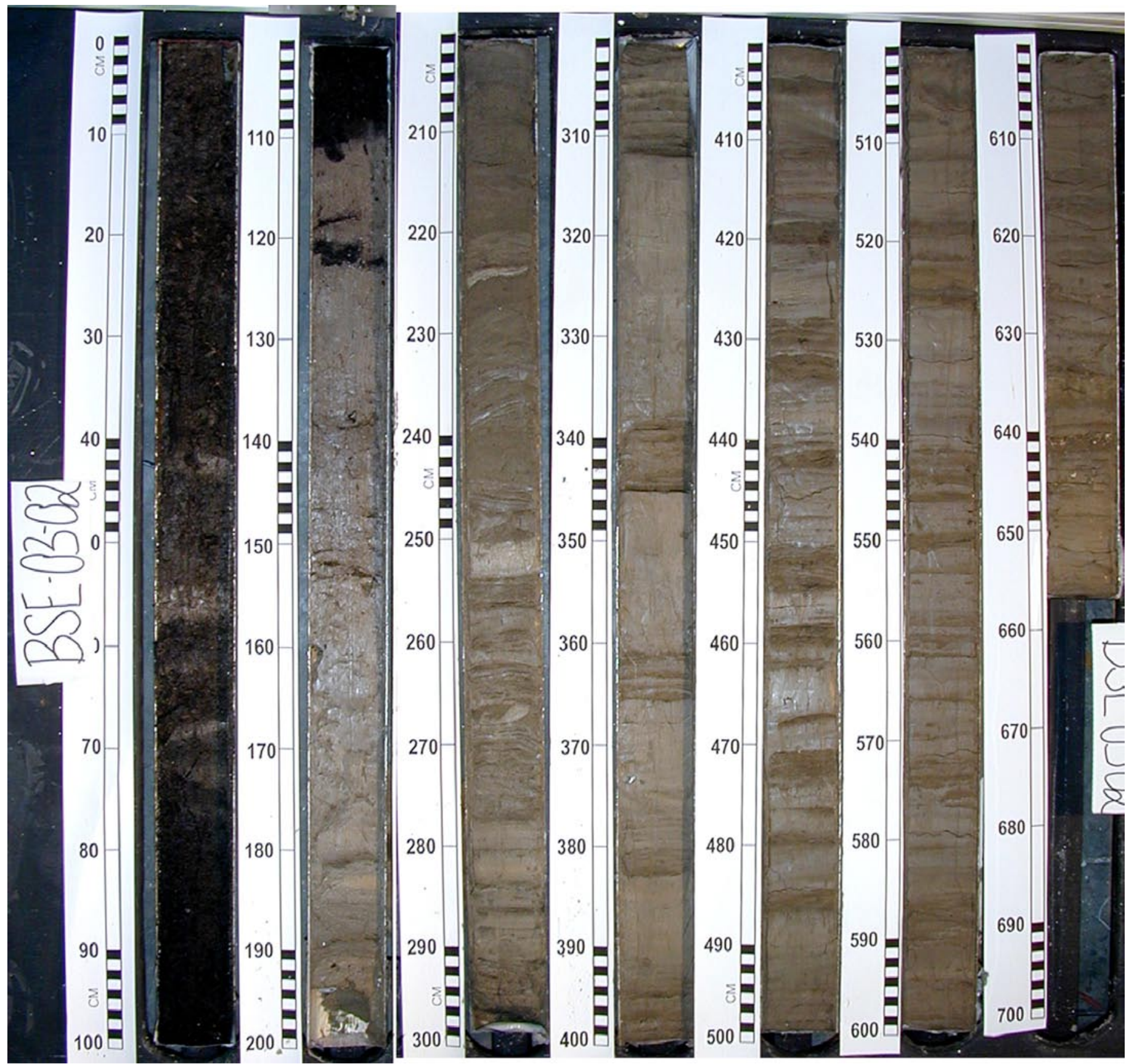


\title{
Composite BSE-03
}

Location: Bay St. Elaine, Terrebonne Parish, LA

Composite core description, from push-core BSE-03-P1 $(0-54 \mathrm{~cm})$ and vibracore BSE 03-03 $(54-554 \mathrm{~cm})$

Core length $554 \mathrm{~cm} \quad$ Corrected (NAVD88) elevation $50 \mathrm{~cm}$

\author{
$0-16 \mathrm{~cm} \quad$ Olive-Gray Mud \\ mud with large root pieces $\sim 5 \mathrm{~cm}$ in length \\ $\sim 75 \%$ organics \\ $16-43 \mathrm{~cm} \quad$ Medium Olive-Gray to Olive-Gray Mud and Muddy Peat \\ mud and fibrous roots \\ $75-90 \%$ organics \\ mud layer from $37-39 \mathrm{~cm}$ \\ $43-54 \mathrm{~cm} \quad$ Olive-Gray Mud \\ $<50 \%$ organics \\ $54-96 \mathrm{~cm} \quad$ Dark Olive-Gray to Black Peat \\ core BSE 03-03, depth in core barrel 25-67 cm \\ fibrous root mat \\ $>90 \%$ organics \\ $96-129 \mathrm{~cm} \quad$ Medium Gray Mud \\ core BSE 03-03, depth in core barrel $67-100 \mathrm{~cm}$ \\ massive mud \\ $129-199 \mathrm{~cm}$ \\ Medium Gray Silty Sand \\ core BSE 03-03, depth in core barrel 100-170 cm \\ mostly massive silty sand \\ $199-229 \mathrm{~cm} \quad$ Medium Gray Mud \\ core BSE 03-03, depth in core barrel 170-200 cm \\ massive mud \\ $229-277 \mathrm{~cm}$ \\ Medium Gray Mud and Sand \\ core BSE 03-03, depth in core barrel 200-248 cm \\ laminated mud with fine-grained sand \\ $277-554 \mathrm{~cm}$ \\ Light Olive-Gray Mud and Sand \\ core BSE 03-03, depth in core barrel 248-525 cm \\ faintly laminated mud interbedded with silt to fine-grained sand
}




\section{Core BSE 03-03}

Location: Bay St. Elaine, Terrebonne Parish, LA

Latitude N 29०09'00.3"

Date cored 09/03/2003

Longitude W 90 42' 58.0"

Water depth $2 \mathrm{~cm}$

Date described 12/15/2003

Core length $525 \mathrm{~cm}$

Corrected (NAVD88) elevation $50 \mathrm{~cm}$

Compaction $101 \mathrm{~cm}$

$0-25 \mathrm{~cm} \quad$ Dark Olive-Gray Muddy Peat

fibrous roots and organics with medium-gray mud

some apparent deformation

$25-67 \mathrm{~cm}$

Dark Olive-Gray to Black Peat

fibrous root mat

$>90 \%$ organics

sharp basal contact is deformed

$67-100 \mathrm{~cm} \quad$ Medium Gray Mud

massive mud

organic clasts $\sim 4 \mathrm{~cm}$ long occur along core edge at 83 and $90 \mathrm{~cm}$

$100-170 \mathrm{~cm} \quad$ Medium Gray Silty Sand

mostly massive silty sand, laminated from $100-120 \mathrm{~cm}$

deformation throughout section

$170-200 \mathrm{~cm} \quad$ Medium Gray Mud

massive mud

deformation throughout section

$200-248 \mathrm{~cm}$

Medium Gray Mud and Sand

laminated mud with fine-grained sand

laminations are deformed throughout section

$248-525 \mathrm{~cm}$

\section{Light Olive-Gray Mud and Sand}

faintly laminated mud interbedded with silt to fine-grained sand

silt and sand laminae are deformed throughout section

shell fragment at $468 \mathrm{~cm}$

wood fragment at $520 \mathrm{~cm}$ 

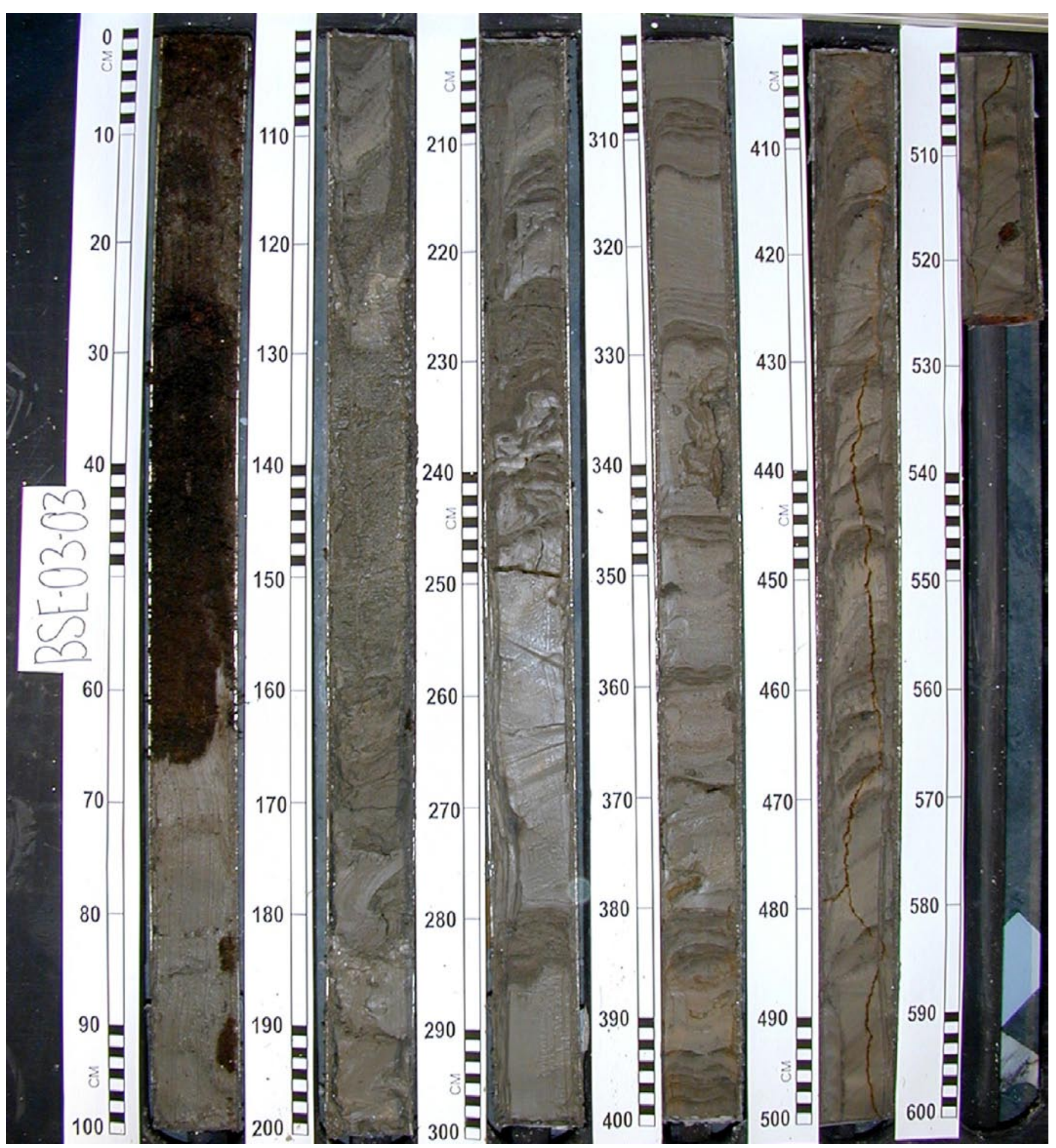
Push-Core BSE-03-P1

Location: Bay St. Elaine, Terrebonne Parish, LA

Latitude N 2909'00.4” Longitude W 90 42' 57.7”

Date cored 07/20/2004 Date described 08/05/2004

Core length $74 \mathrm{~cm} \quad$ Compaction $107 \mathrm{~cm}$

$0-16 \mathrm{~cm} \quad$ Olive-Gray Mud

mud with large root pieces $\sim 5 \mathrm{~cm}$ in length

$\sim 75 \%$ organics

gradational basal contact

$16-43 \mathrm{~cm} \quad$ Medium Olive-Gray to Olive-Gray Mud and Muddy Peat

mud and fibrous roots

$75-90 \%$ organics

mud layer from $37-39 \mathrm{~cm}$

gradational basal contact

$43-54 \mathrm{~cm}$

Olive-Gray Mud

$<50 \%$ organics

gradational basal contact

$54-74 \mathrm{~cm} \quad$ Dark Brown to Black Peat

$>90 \%$ organics 


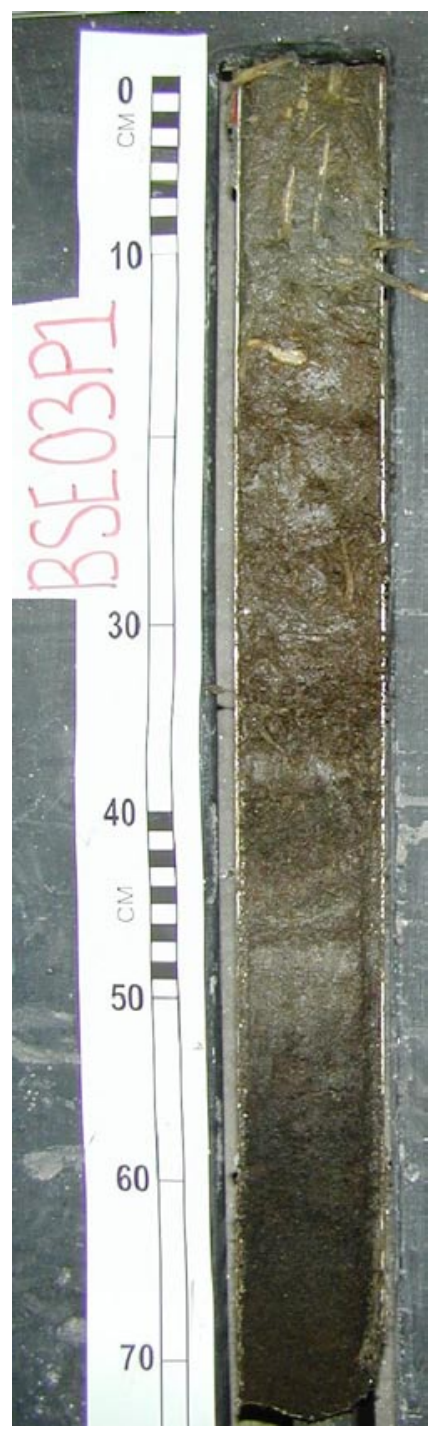




\section{Composite BSE-04}

Location: Bay St. Elaine, Terrebonne Parish, LA

Composite core description, from push-core BSE-04-P1 $(0-54 \mathrm{~cm})$ and vibracore BSE 03-04 $(54-414 \mathrm{~cm})$

Core length $414 \mathrm{~cm} \quad$ Corrected (NAVD88) elevation $49 \mathrm{~cm}$

$0-20 \mathrm{~cm}$

Olive-Gray Mud

mud with small fibrous roots

$\sim 25 \%$ organics

$20-27 \mathrm{~cm} \quad$ Olive-Gray Mud

mud with some larger roots $5-10 \mathrm{~cm}$ in length

$27-33 \mathrm{~cm}$

Olive-Gray Mud

mud with fibrous roots

$\sim 25 \%$ organics

$33-54 \mathrm{~cm}$

Dark Olive-Gray Mud and Muddy Peat

mud with fibrous roots

$\sim 75 \%$ organics

$54-105 \mathrm{~cm}$

Dark Olive-Gray to Black Peat

core BSE 03-04, depth in core barrel 21-72 cm

fibrous root mat

$>90 \%$ organics

sample BSE-04-021/022: conventional age $320 \pm 40 \mathrm{BP}, \delta^{13} \mathrm{C}-24.6 \%$ 。

sample BSE-04-071/072: conventional age $680 \pm 40 \mathrm{BP}, \mathrm{\delta}^{13} \mathrm{C}-24.8 \%$ 。

$105-183 \mathrm{~cm}$

\section{Light Olive-Gray Mud}

core BSE 03-04, depth in core barrel 72-150 cm

mud with fibrous roots and some larger organics

$\sim 25 \%$ organics

$183-414 \mathrm{~cm} \quad$ Medium Gray Mud and Sand

core BSE 03-04, depth in core barrel 150-381 cm

laminated mud and very fine-grained sand 


\section{Core BSE 03-04}

Location: Bay St. Elaine, Terrebonne Parish, LA

Latitude N 29०09'08.8',

Longitude W $90^{\circ} 43^{\prime}$ 01.1"

Date cored 09/03/2003

Date described 12/04/2003

Water depth $2 \mathrm{~cm}$

Corrected (NAVD88) elevation $49 \mathrm{~cm}$

Core length $381 \mathrm{~cm}$

Compaction $92 \mathrm{~cm}$

$0-12 \mathrm{~cm}$

$12-21 \mathrm{~cm}$

$21-72 \mathrm{~cm}$

$72-150 \mathrm{~cm}$

$150-381 \mathrm{~cm}$

\section{Light Olive-Gray Mud}

mud with fibrous roots

$\sim 50 \%$ organics

\section{Olive-Gray Peat and Mud}

muddy fibrous root mat interbedded with light olive-gray gray mud peat layers $>80 \%$ organics

bed thickness $2-3 \mathrm{~cm}$

\section{Dark Olive-Gray to Black Peat}

fibrous root mat

$>90 \%$ organics

sharp basal contact

sample BSE-04-021/022: conventional age $320 \pm 40 \mathrm{BP}, \delta^{13} \mathrm{C}-24.6 \%$ 。 sample BSE-04-071/072: conventional age $680 \pm 40 \mathrm{BP}, \delta^{13} \mathrm{C}-24.8 \%$ 。

\section{Light Olive-Gray Mud}

mud with fibrous roots and some larger organics

$\sim 25 \%$ organics

gradational basal contact

\section{Medium Gray Mud and Sand}

laminated mud and very fine-grained sand

tan to yellow horizons $\sim 3 \mathrm{~mm}$ thick at 250,280, and $320 \mathrm{~cm}$

some deformation throughout section, primarily in sandy laminae 


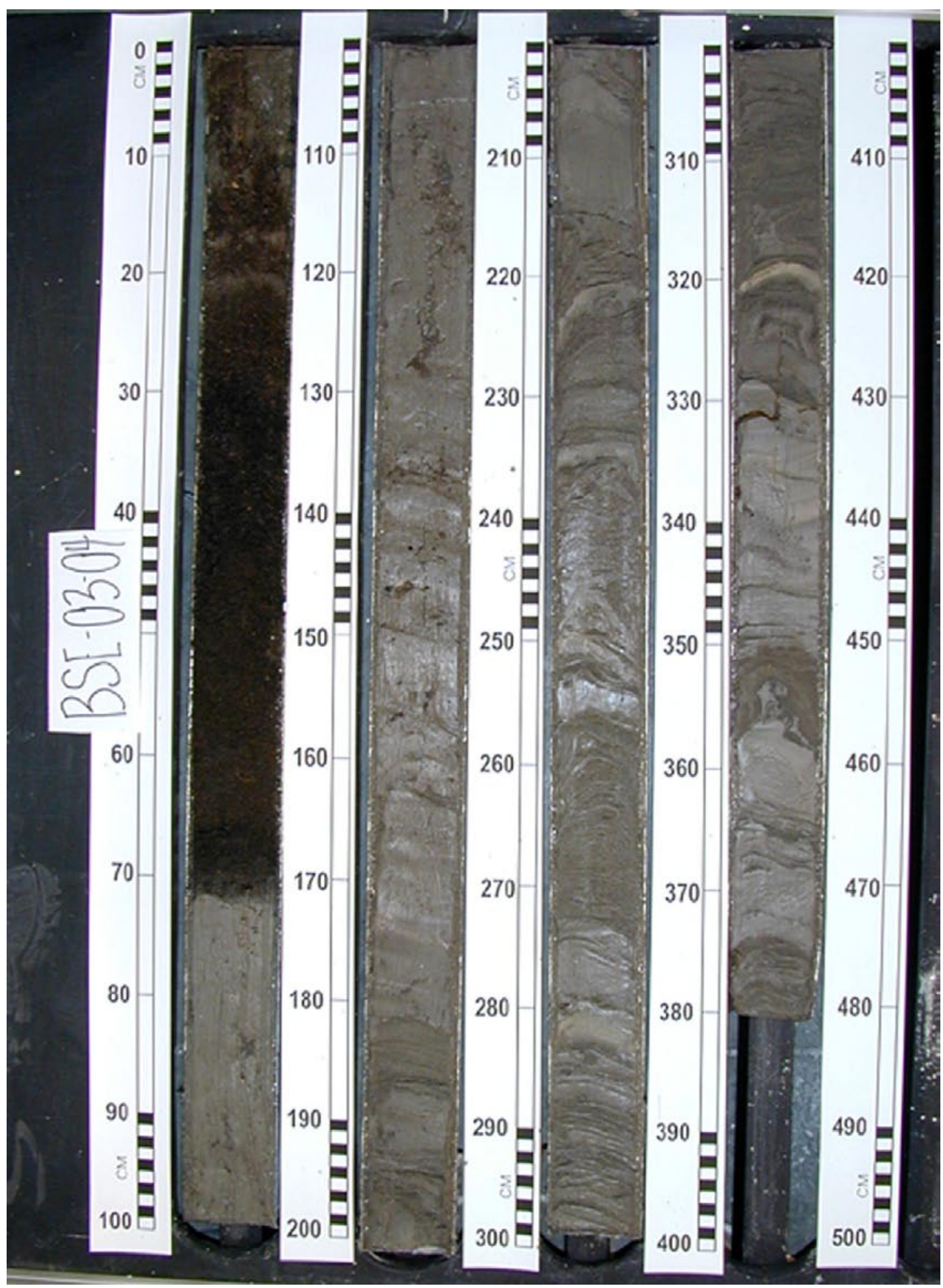


Push-Core BSE-04-P1

Location: Bay St. Elaine, Terrebonne Parish, LA

Latitude N 29०09' 09.1” Longitude W 90 43'01.4”

Date cored 07/20/2004 Date described 08/05/2004

Core length $61 \mathrm{~cm} \quad$ Compaction $61 \mathrm{~cm}$

$0-20 \mathrm{~cm} \quad$ Olive-Gray Mud

mud with small fibrous roots

$\sim 25 \%$ organics

$20-27 \mathrm{~cm} \quad$ Olive-Gray Mud

mud with some larger roots $5-10 \mathrm{~cm}$ in length

$27-33 \mathrm{~cm} \quad$ Olive-Gray Mud

mud with fibrous roots

$\sim 25 \%$ organics

sharp basal contact

$33-54 \mathrm{~cm}$

Dark Olive-Gray Mud and Muddy Peat

mud with fibrous roots, some larger pieces from $48-54 \mathrm{~cm}$

$\sim 75 \%$ organics

$54-61 \mathrm{~cm} \quad$ Dark Olive-Gray to Black Peat

$>90 \%$ organics 


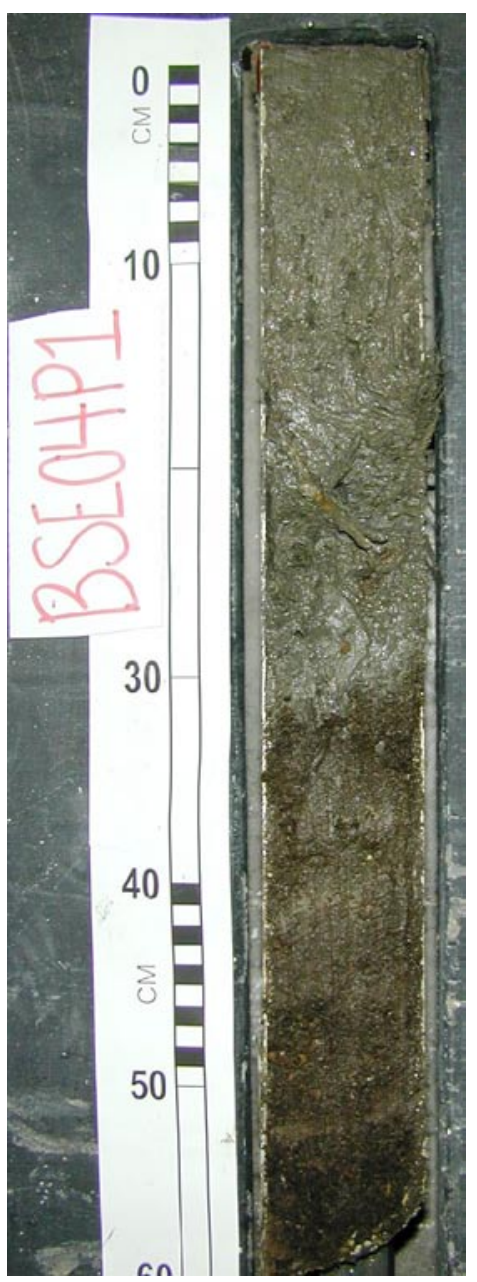




\section{Core BSE 03-05}

Location: Bay St. Elaine, Terrebonne Parish, LA Latitude N 2909'06.8'" Longitude W $90^{\circ} 42^{\prime} 56.8^{\prime \prime}$

Date cored 09/03/2003 Date described 12/04/2003

Water depth $55 \mathrm{~cm}$ Corrected (NAVD88) depth $7 \mathrm{~cm}$

Core length $430 \mathrm{~cm}$

Compaction $62 \mathrm{~cm}$

$0-38 \mathrm{~cm}$

$38-64 \mathrm{~cm}$

$64-112 \mathrm{~cm}$

$112-155 \mathrm{~cm}$

$155-200 \mathrm{~cm}$

$200-430 \mathrm{~cm}$

\section{Dark Olive-Gray Peat}

fibrous root mat with some clastics

sample BSE-05-037/038: conventional age $200 \pm 40 \mathrm{BP}, \delta^{13} \mathrm{C}-13.9 \%$ o

\section{Olive-Gray Muddy Peat}

fibrous muddy root mat

sharp basal contact

\section{Black Peat}

fibrous root mat

$>90 \%$ organics

sharp basal contact

\section{Light Olive-Gray Mud}

massive mud with organic material and root traces

$\sim 25 \%$ organics

gradational basal contact

\section{Medium Gray Mud}

massive mud

$<10 \%$ organics

\section{Medium Gray Mud and Sand}

interbedded mud and very fine-grained sand

bed thickness $1 \mathrm{~mm}$ to $10 \mathrm{~cm}$

contacts between sand and mud sharp to gradational

some deformation from $200-220 \mathrm{~cm}$

tan to yellow horizons at 220,260, 270, 280, and $285 \mathrm{~cm}$ 


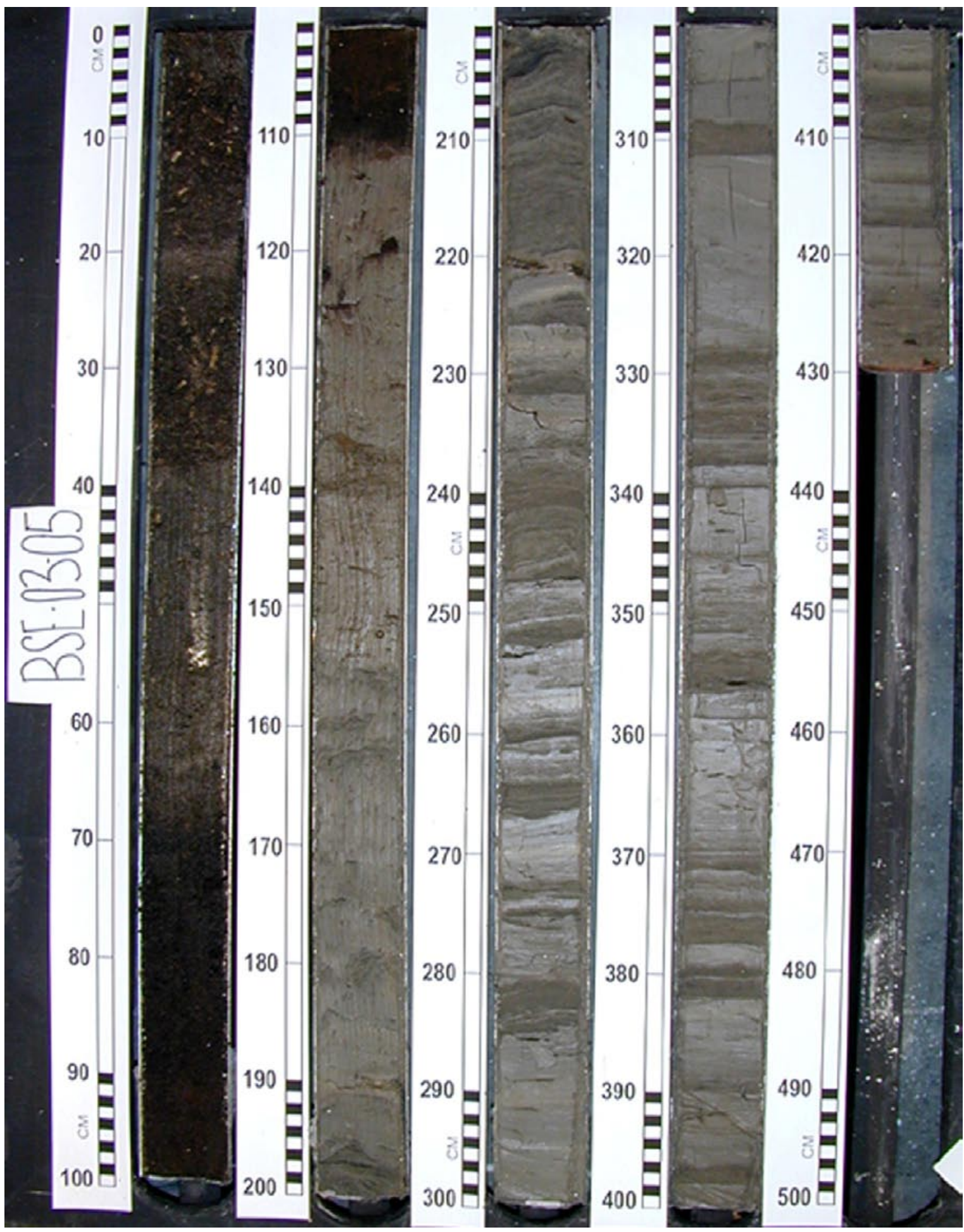




\section{Core MB 04-02-01}

Location: Madison Bay, Terrebonne Parish, LA

Latitude N 29²0'20.14” Longitude W 90³6'03.23”

Date cored 04/30/02 Date described 05/21/02

Water depth $82 \mathrm{~cm} \quad$ Corrected NAVD88) depth $46 \mathrm{~cm}$

Core length $380 \mathrm{~cm} \quad$ Compaction $58 \mathrm{~cm}$

$0-125 \mathrm{~cm} \quad$ Black Peat

fibrous root mat

$>80 \%$ organics with some clay and silt

muddy with some roots from $0-7 \mathrm{~cm}$

muddy peat with roots more abundant from $7-17 \mathrm{~cm}$

sharp basal contact

$125-208 \mathrm{~cm}$

\section{Brownish-Black to Dark Gray Mud}

massive, hydrous mud with $30-40 \%$ root traces

$\sim 60 \%$ silt, $40 \%$ clay

roots more abundant from $164-168 \mathrm{~cm}$

more organic-rich from $182-186 \mathrm{~cm}$

muddy peat with roots more abundant from $200-206 \mathrm{~cm}$

sharp basal contact

\section{$208-326 \mathrm{~cm} \quad$ Olive-Gray Mud}

coarser-grained than above section, with no root traces

$\sim 70 \%$ silt, $30 \%$ clay

large root mass $\sim 3 \mathrm{~cm}$ long at $212 \mathrm{~cm}$

very fine-grained sandy horizon from $277-290 \mathrm{~cm}$

possible small mica flakes and/or organics

gradational basal contact

$326-360 \mathrm{~cm}$

\section{Light Olive-Gray Sand}

massive, very fine-grained sand with $\sim 25 \%$ silt

no shells or roots

sharp basal contact

$360-380 \mathrm{~cm}$

\section{Light Olive-Gray Silty Sand}

massive silty sand

slightly darker than overlying section

root trace or wood at $367 \mathrm{~cm}$ 


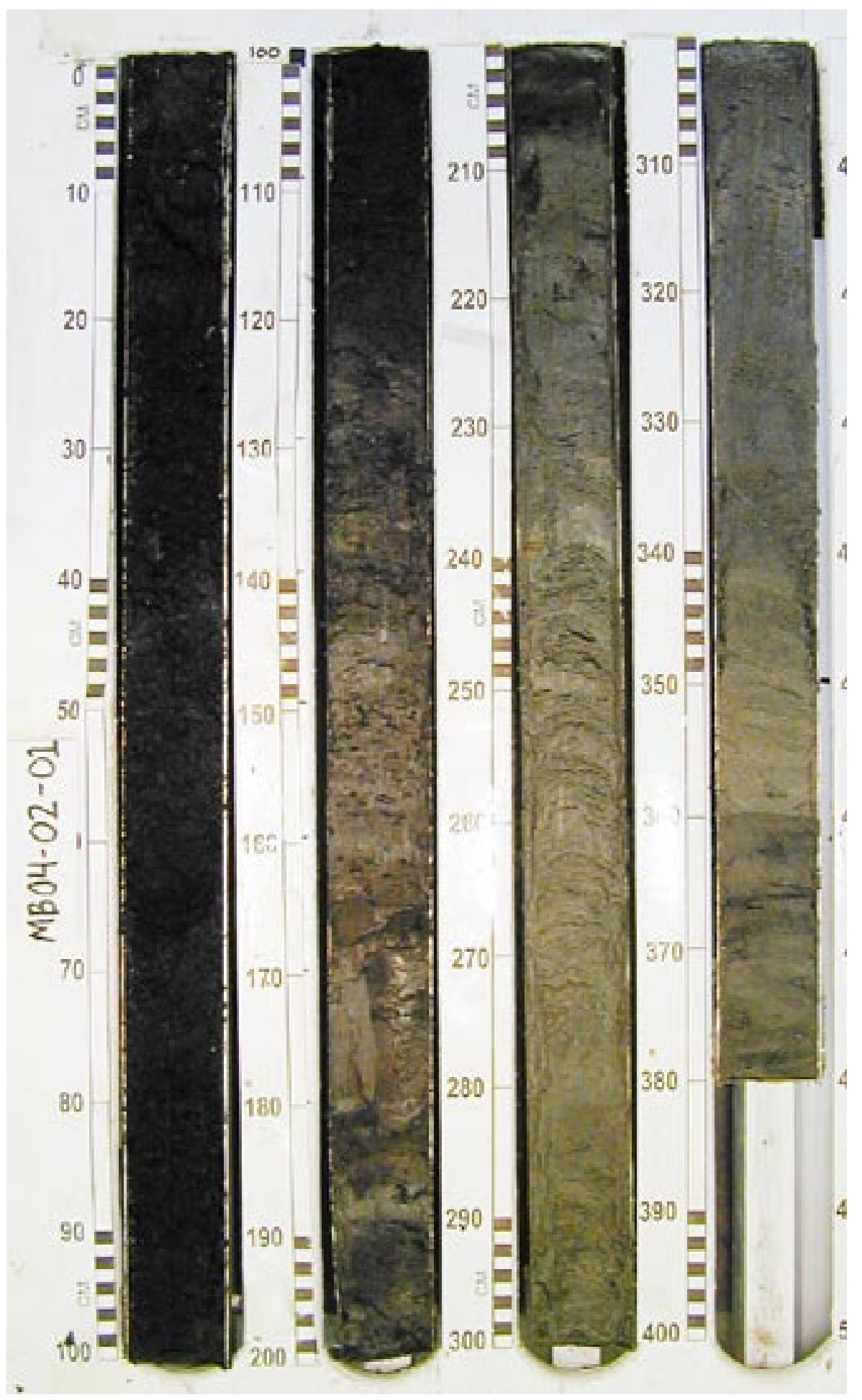




\section{Core MB 04-02-02}

Location: Madison Bay, Terrebonne Parish, LA

Latitude N 2920'09.87” Longitude W 90³4' 48.79'”

Date cored 04/30/02 Date described 05/29/02

Water depth $98 \mathrm{~cm} \quad$ Corrected (NAVD88) depth $59 \mathrm{~cm}$

Core length $353 \mathrm{~cm} \quad$ Compaction $8 \mathrm{~cm}$

$0-134 \mathrm{~cm} \quad$ Black Peat

root mat with some large roots $\sim 5 \mathrm{~cm}$ in length

$>80 \%$ fibrous roots

muddy peat from $0-18 \mathrm{~cm}$

rafted wood or large root $\sim 6 \mathrm{~cm}$ long and $2 \mathrm{~cm}$ wide at $38 \mathrm{~cm}$

sharp basal contact

sample MB-02-133/134: conventional age $840 \pm 40 \mathrm{BP}, \mathrm{\delta}^{13} \mathrm{C}-26.0 \%$ o

$134-145 \mathrm{~cm}$

\section{Dark Olive-Gray Mud}

mud with $30-40 \%$ root traces

sharp basal contact

$145-151 \mathrm{~cm} \quad$ Black Peat

root mat

$>80 \%$ fibrous roots

sharp basal contact

sample MB-02-045/146: conventional age $940 \pm 40 \mathrm{BP}, \delta^{13} \mathrm{C}-25.6 \%$

sample MB-02-150/151: conventional age $930 \pm 40 \mathrm{BP}, \mathrm{\delta}^{13} \mathrm{C}-25.8 \%$ 。

$151-240 \mathrm{~cm}$

\section{Olive-Gray Mud}

mud with $\sim 40 \%$ root traces, root traces become less abundant down section more organic-rich from 155-157, 166-171, and 177-184 cm

gradational basal contact

$240-353 \mathrm{~cm}$

\section{Light Olive-Gray Muddy Sand}

massive, very fine-grained sand

no organics

faint parallel laminations 


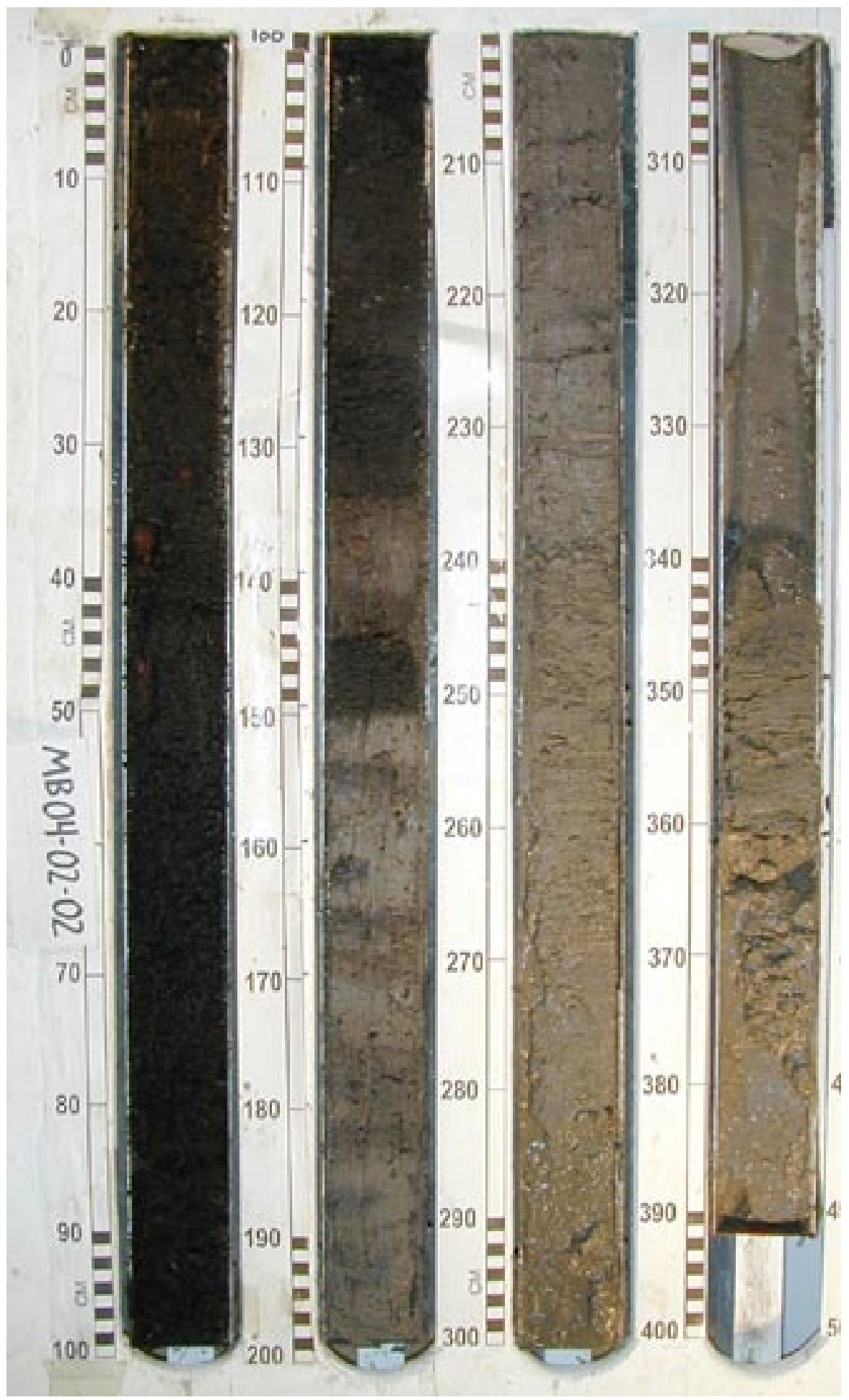




\section{Core MB 04-02-03}

Location: Madison Bay, Terrebonne Parish, LA

Latitude N 2920'56.71” Longitude W 90³4'30.37”

Date cored 04/31/02 Date described 06/04/02

Water depth $116 \mathrm{~cm} \quad$ Corrected (NAVD88) depth $77 \mathrm{~cm}$

Core length $450 \mathrm{~cm} \quad$ Compaction $21 \mathrm{~cm}$

$0-138 \mathrm{~cm} \quad$ Black Peat

fibrous root mat

$>90 \%$ organics

muddy peat from $0-36 \mathrm{~cm}$

hydrous organic-rich mud and muddy peat from $118-126$ and $131-138 \mathrm{~cm}$

color becomes more brown in basal $\sim 5 \mathrm{~cm}$

gradational basal contact

$138-200 \mathrm{~cm}$

\section{Olive-Gray Mud}

$\sim 60 \%$ clay, $40 \%$ silt

20-30\% organics

peat and muddy peat from $138-141 \mathrm{~cm}$

more organic-rich from 151-154 and 159-162 cm

sharp basal contact

$200-310 \mathrm{~cm}$

\section{Medium Olive-Gray Silt}

massive silt with $20-30 \%$ fine-grained sand and 10-20\% mud possible mica flake clusters at 268 and $301 \mathrm{~cm}$

gradational basal contact

$310-450 \mathrm{~cm}$

\section{Medium to Light Olive-Gray Muddy Sand}

parallel-laminated fine-grained sand and silt with $10-20 \%$ clay

organic layer and/or wood from 353-355 cm

laminae are deformed throughout section 


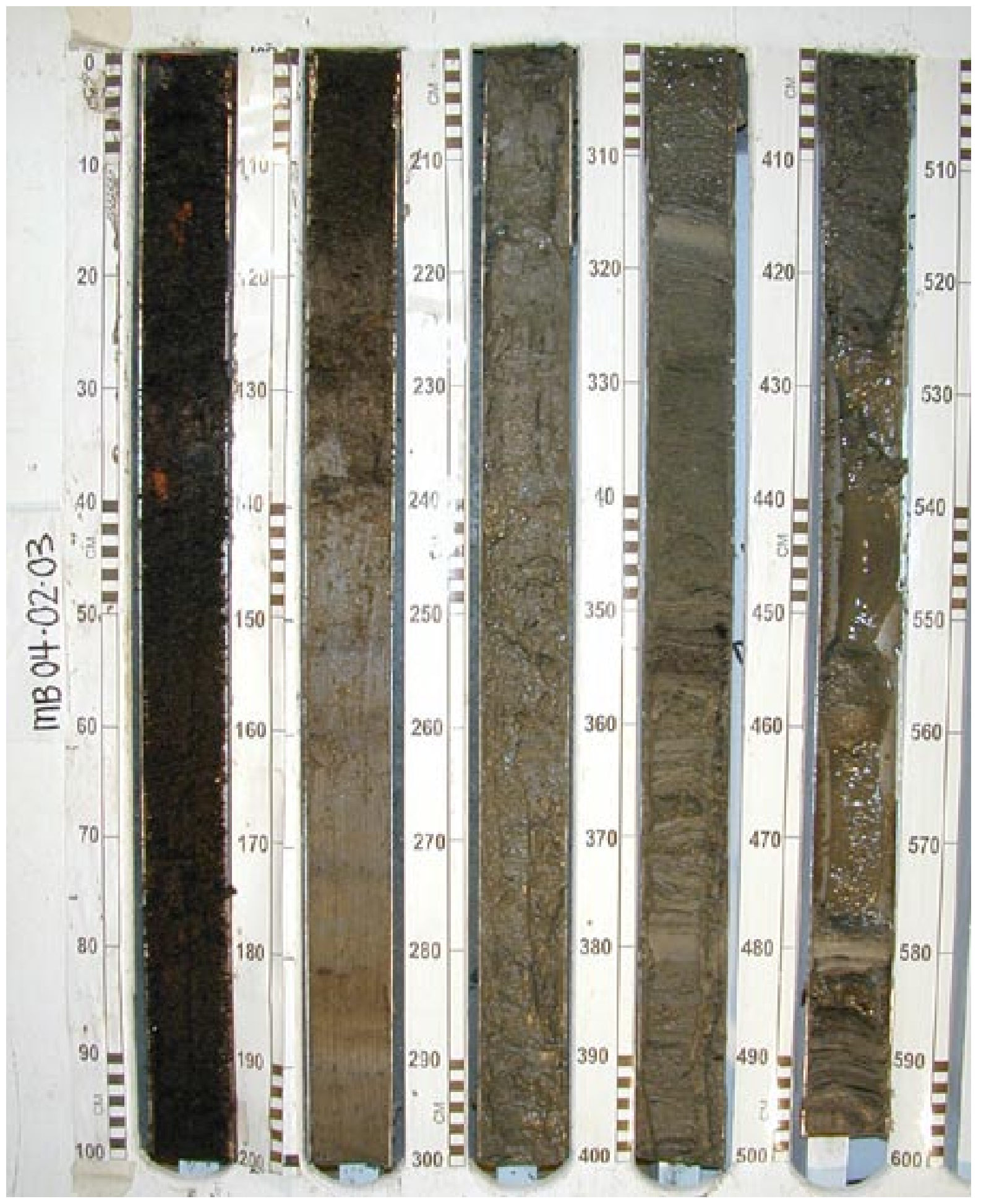




\section{Core MB 04-02-04}

Location: Madison Bay, Terrebonne Parish, LA

Latitude N 2921' 11.53” Longitude W 90³5'03.16"

Date cored 04/02/02 Date described 05/22/02

Water depth $150 \mathrm{~cm} \quad$ Corrected (NAVD88) depth $108 \mathrm{~cm}$

Core length $389 \mathrm{~cm} \quad$ Compaction $43 \mathrm{~cm}$

$0-90 \mathrm{~cm} \quad$ Black Peat

fibrous root mat with roots $2-4 \mathrm{~cm}$ long

$>90 \%$ organics

mud and muddy peat from $0-13 \mathrm{~cm}$

some oxidation and decreasing organic content from $85-90 \mathrm{~cm}$

gradational basal contact

$90-107 \mathrm{~cm} \quad$ Medium Olive-Gray Mud

massive mud with $\sim 15 \%$ roots

more organic-rich from $98-100 \mathrm{~cm}$

sharp basal contact

$107-134 \mathrm{~cm} \quad$ Medium Olive-Gray Peat

root mat with roots $\sim 2 \mathrm{~cm}$ in length

$>75 \%$ fibrous roots

organic-rich mud from $114-120 \mathrm{~cm}$

muddy peat from $120-130 \mathrm{~cm}$

sharp basal contact is slightly deformed

sample MB-04-107/108: conventional age $720 \pm 40 \mathrm{BP}, \delta^{13} \mathrm{C}-26.6 \%$ o sample MB-04-113/114: conventional age $700 \pm 40 \mathrm{BP}, \delta^{13} \mathrm{C}-27.0 \%$ sample MB-04-133/134: conventional age $960 \pm 40 \mathrm{BP}, \delta^{13} \mathrm{C}-26.7 \%$ 。

$134-230 \mathrm{~cm}$

Dark Green-Gray Mud

mud with rare root traces

stiff texture

tan clay clast at $170 \mathrm{~cm}$

sharp basal contact is deformed

$230-389 \mathrm{~cm} \quad$ Dark Green-Gray Mud

mostly massive, hydrous mud with some deformed parallel laminations no organics

very fine-grained sand from $290-310 \mathrm{~cm}$

clay clast $\sim 5 \mathrm{~cm}$ in length at $310 \mathrm{~cm}$

parallel laminations of silt and sand from $310-389 \mathrm{~cm}$

tan mud layer $1.5 \mathrm{~cm}$ thick at $375 \mathrm{~cm}$ 


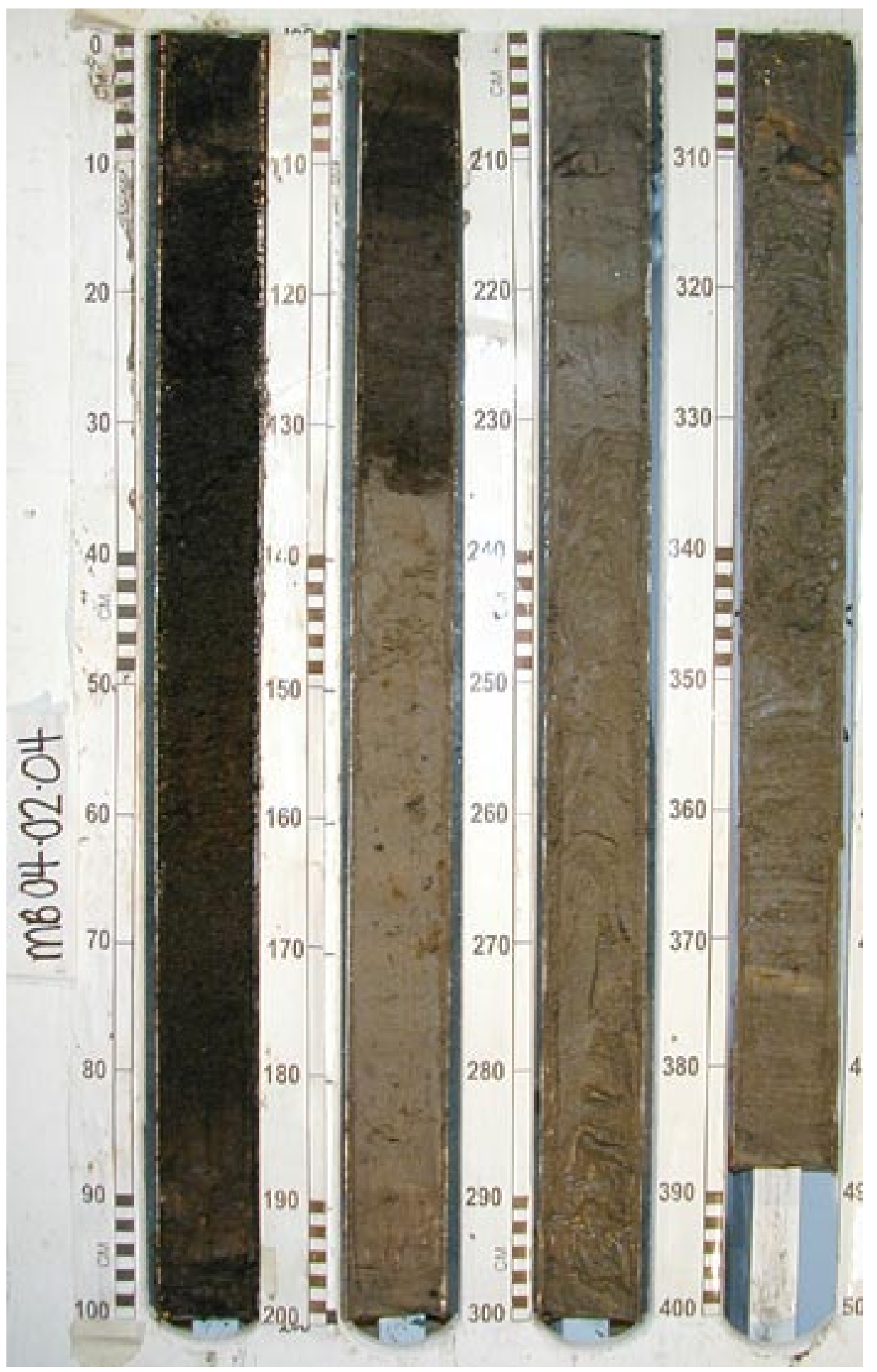




\section{Core MB 04-02-05}

Location: Madison Bay, Terrebonne Parish, LA

Latitude N 2921'29.52” Longitude W 90³4' 45.21"

Date cored 04/31/02 Date described 06/03/02

Water depth $130 \mathrm{~cm} \quad$ Corrected (NAVD88) depth $92 \mathrm{~cm}$

Core length $400 \mathrm{~cm} \quad$ Compaction $14 \mathrm{~cm}$

$0-111 \mathrm{~cm} \quad$ Black Peat

fibrous root mat

$>90 \%$ organics

muddy peat from $0-4 \mathrm{~cm}$

some larger roots $\sim 5 \mathrm{~cm}$ in length from $60-80 \mathrm{~cm}$

some oxidation and decreasing organic content from $107-111 \mathrm{~cm}$

gradational basal contact

$111-122 \mathrm{~cm}$

Dark Olive-Gray Mud

massive mud

$50-60 \%$ organics

more organic-rich from 116-118 cm

$122-134 \mathrm{~cm}$

\section{Olive-Gray Muddy Peat}

$>80 \%$ organics

$134-250 \mathrm{~cm}$

\section{Light Olive-Gray Mud}

$\sim 50 \%$ clay, $50 \%$ silt with well preserved root traces

$\sim 20 \%$ roots and organics

more organic-rich from 137-139, 145-148, and 150-152 cm

organic content decreases down core

gradational basal contact

$250-342 \mathrm{~cm}$

\section{Light Olive-Gray Silt and Sand}

$\sim 40 \%$ sand, $40 \%$ silt, and $20 \%$ clay

some clay laminae $\sim 0.5 \mathrm{~cm}$ thick

sharp basal contact

$342-400 \mathrm{~cm}$

\section{Light Olive Silty Sand}

massive silty sand

no shells or organics 


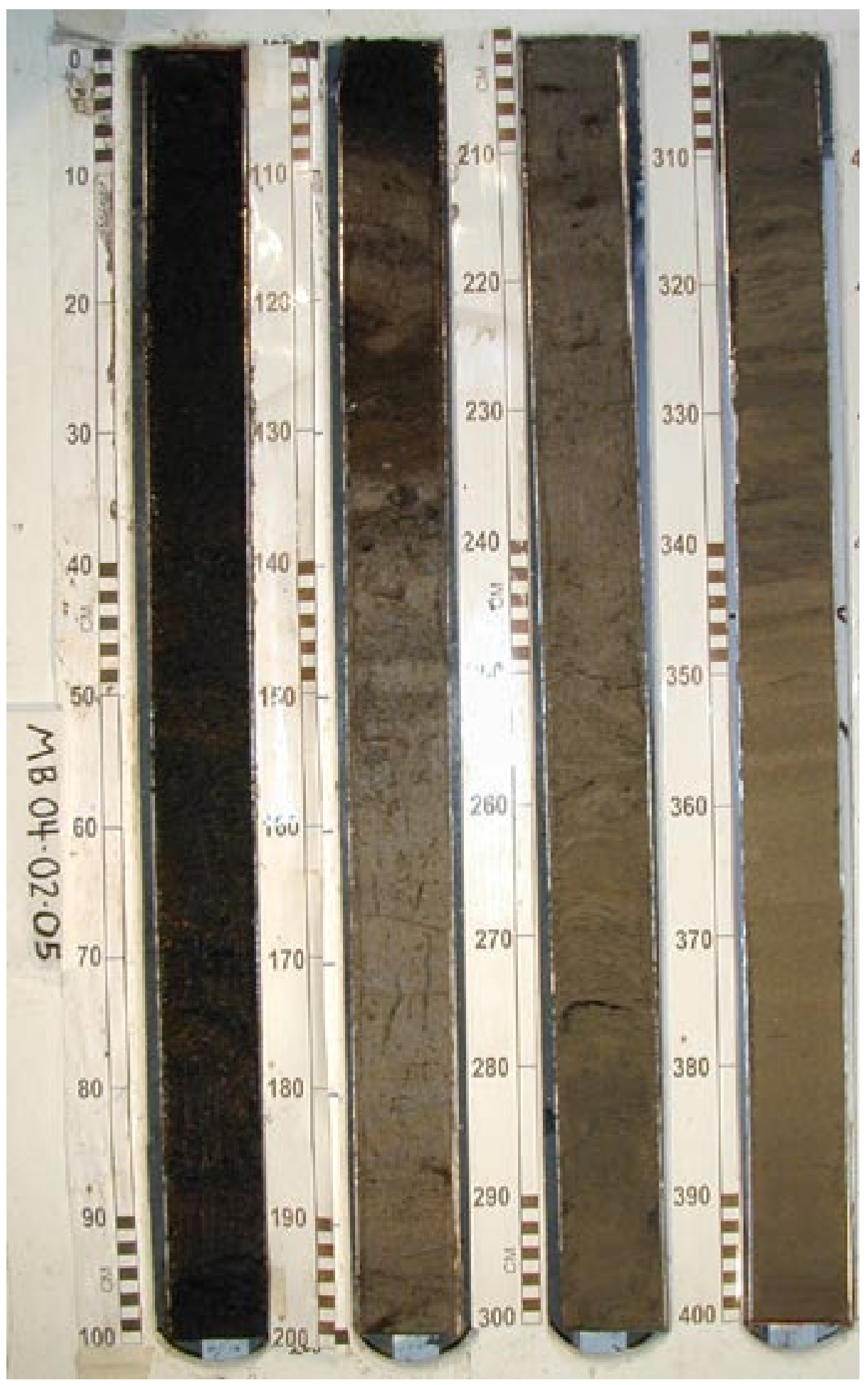




\section{Core MB 04-02-06}

Location: Madison Bay, Terrebonne Parish, LA

Latitude N 2921'54.03” Longitude W 90³4' 56.59”

Date cored 05/01/02 Date described 06/03/02

Water depth $101 \mathrm{~cm} \quad$ Corrected (NAVD88) depth $58 \mathrm{~cm}$

Core length $451 \mathrm{~cm} \quad$ Compaction $27 \mathrm{~cm}$

0 $-129 \mathrm{~cm} \quad$ Black Peat

fibrous root mat

$>85 \%$ organics

muddy peat with large fibrous roots $\sim 5 \mathrm{~cm}$ in length from $0-19 \mathrm{~cm}$

angular contact between muddy peat and peat from $12-19 \mathrm{~cm}$

color change to dark olive-gray from 73-96 cm

slightly deformed olive-gray muddy horizon ( 50\% organics) from $106-108 \mathrm{~cm}$

sharp basal contact

$129-240 \mathrm{~cm}$

\section{Olive-Gray Mud}

massive mud, $\sim 70 \%$ clay, $30 \%$ silt

$\sim 40 \%$ organics, organic content decreases down core to $170 \mathrm{~cm}$

muddy peat from $170-175 \mathrm{~cm}$

more organic-rich from 177-179 and 184-188 cm

roots or wood fragments at $187 \mathrm{~cm}$

gradual color change down core to light olive-gray

gradational basal contact

$240-357 \mathrm{~cm}$

\section{Light Olive-Gray Silty Sand}

$\sim 60 \%$ fine-grained sand, $40 \%$ silt

faint parallel laminations

finer-grained layer at $301 \mathrm{~cm}$

yellowish-tan layer $1 \mathrm{~cm}$ thick at $321 \mathrm{~cm}$

shell fragments at $323 \mathrm{~cm}$

sharp basal contact

\section{$357-370 \mathrm{~cm} \quad$ Light Olive-Gray Sand}

mostly massive fine-grained sand with some silt

gradational basal contact

$370-451 \mathrm{~cm}$

\section{Medium Olive-Gray Sand}

fine-grained sand with 25\% silt

mica layer at $410 \mathrm{~cm}$

shell fragments at $415 \mathrm{~cm}$

yellowish-tan mud layer $2 \mathrm{~cm}$ thick at $435 \mathrm{~cm}$ 


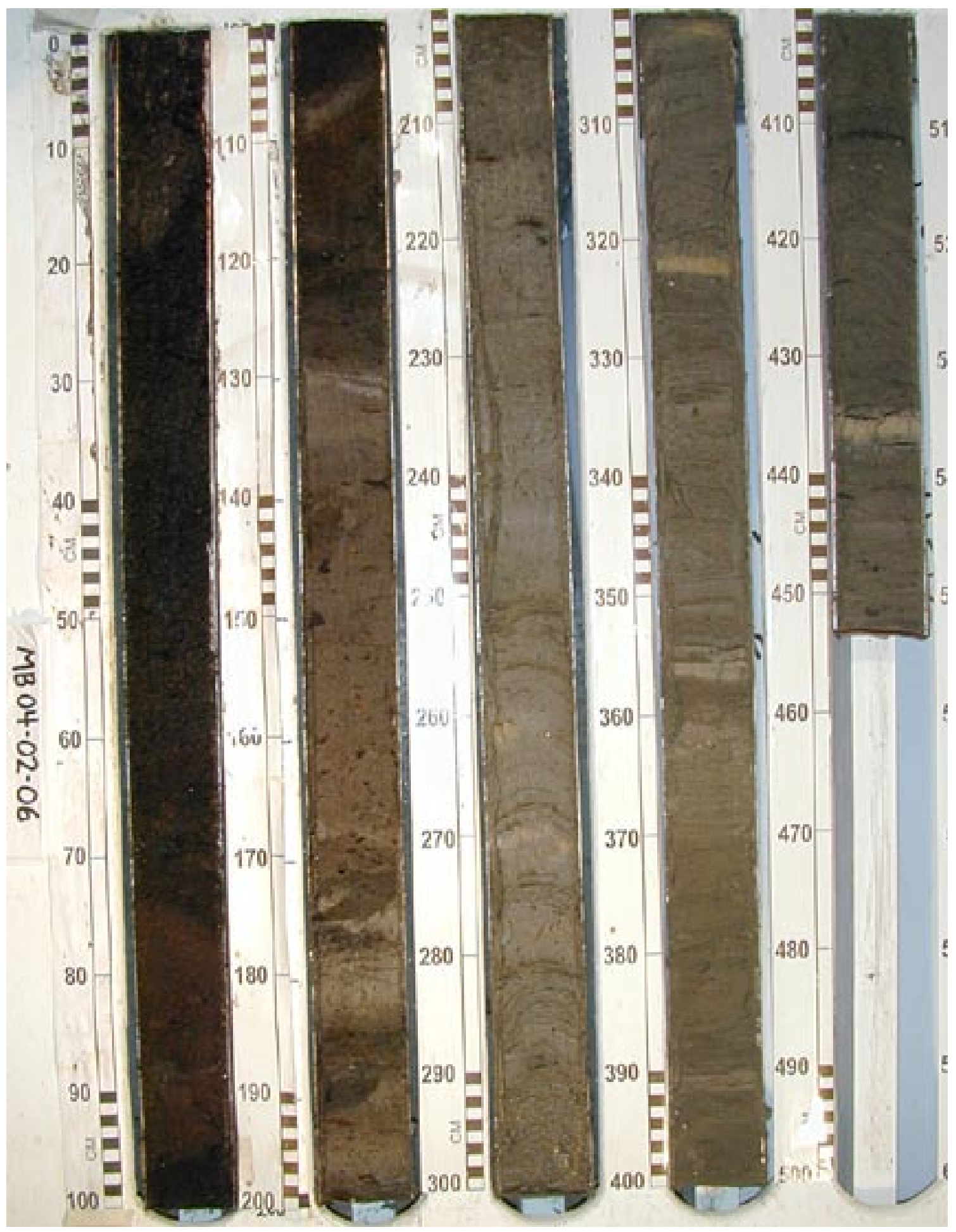




\section{Core MB 04-02-07}

Location: Madison Bay, Terrebonne Parish, LA Latitude N $29^{\circ} 20^{\prime} 19.32^{\prime \prime}$

Date cored 05/07/02

Longitude W 90³6'04.31"

Water depth $12 \mathrm{~cm}$

Date described 05/21/02

Core length $450 \mathrm{~cm}$

Corrected (NAVD88) elevation $24 \mathrm{~cm}$

Compaction $90 \mathrm{~cm}$

$0-20 \mathrm{~cm}$

$20-55 \mathrm{~cm}$

$55-115 \mathrm{~cm}$

$115-208 \mathrm{~cm}$

$208-299 \mathrm{~cm}$

$299-312 \mathrm{~cm}$

$312-412 \mathrm{~cm}$

$412-450 \mathrm{~cm}$

\section{Olive-Gray Mud}

mud with $30-40 \%$ fibrous roots

gradational basal contact

\section{Olive-Gray Mud}

clay with $60-70 \%$ large roots $\sim 5-6 \mathrm{~mm}$ around and $10 \mathrm{~cm}$ long gradational basal contact

\section{Black Peat}

root mat

$80-90 \%$ fibrous roots with organic-rich mud

gradational basal contact

sample MB-07-114/115: conventional age $600 \pm 40 \mathrm{BP}, \mathrm{\delta}^{13} \mathrm{C}-25.8 \%$ o

\section{Olive-Gray Organic-Rich Mud}

mud with $60-70 \%$ fibrous roots

muddy peat from 168-176 and 186-192 cm

deformed light olive-gray clay beds at 176-184 and 195-197 cm

more organic-rich with some oxidation and decreasing organic content from 195-208 cm

sharp basal contact

sample MB-07-186/187: conventional age $980 \pm 40 \mathrm{BP}, \delta^{13} \mathrm{C}-26.3 \%$ o sample MB-07-191/192: conventional age $950 \pm 40 \mathrm{BP}, \delta^{13} \mathrm{C}-26.5 \%$ o

\section{Light Olive-Gray Silty Sand}

mostly massive silty sand, $~ 60 \%$ sand, $40 \%$ silt

some faint parallel laminations

large root mass at $260 \mathrm{~cm}$

gradational basal contact

\section{Light Olive-Gray Silty Sand}

$\sim 60 \%$ sand, $40 \%$ silt

no organics

\section{Light Olive-Gray Silty Sand}

massive silty sand

freshwater shell at $350 \mathrm{~cm}$

organic lens at $362 \mathrm{~cm}$

sharp basal contact

\section{Light Olive-Gray Silty Sand}

faint parallel laminations 


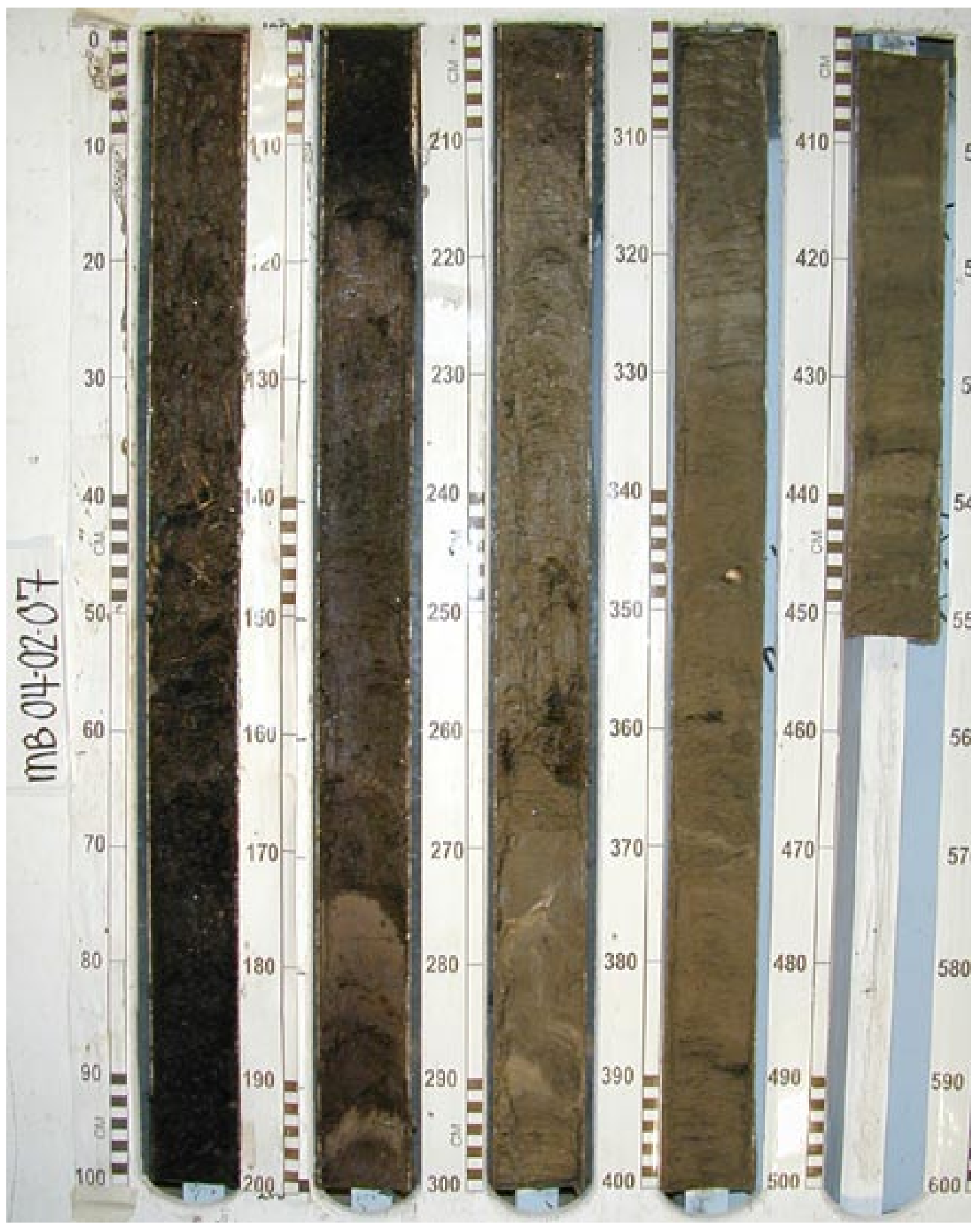




\section{Core MB 05-02-08}

Location: Madison Bay, Terrebonne Parish, LA

Latitude N 2920'08.83” Longitude W 90³4' 51.09”

Date cored 05/02/02 Date described 05/30/02

Water depth $21 \mathrm{~cm} \quad$ Corrected (NAVD88) elevation $20 \mathrm{~cm}$

Core length $487 \mathrm{~cm} \quad$ Compaction $47 \mathrm{~cm}$

$0-180 \mathrm{~cm} \quad$ Olive-Gray Peat

fibrous root mat

$>90 \%$ organics

muddy peat with $\sim 60 \%$ roots from $0-16 \mathrm{~cm}$

muddy peat with large roots from $16-47 \mathrm{~cm}$

color change to black from $75-180 \mathrm{~cm}$

organic-rich mud and muddy peat from 161-171 cm

sharp basal contact

$180-266 \mathrm{~cm}$

\section{Medium Olive-Gray Mud}

$\sim 50 \%$ clay, $50 \%$ silt

$\sim 30-40 \%$ root fragments

more organic-rich from 183-185, 190-196, and 202-206 cm

black organic rich mud from $262-264 \mathrm{~cm}$

sharp basal contact

$266-400 \mathrm{~cm} \quad$ Light Olive-Gray Sandy Mud

$\sim 60 \%$ mud, $40 \%$ very fine-grained sand, grain size increases down core organic rich layer from $327-330 \mathrm{~cm}$

clay clast $\sim 3 \mathrm{~cm}$ wide at $361 \mathrm{~cm}$

gradational basal contact

$400-487 \mathrm{~cm}$

\section{Light Olive-Gray Mud and Sand}

parallel-laminated mud and very fine-grained sand yellowish-gray lamination $\sim 1.5 \mathrm{~cm}$ thick at $444 \mathrm{~cm}$

slight deformation of laminae 


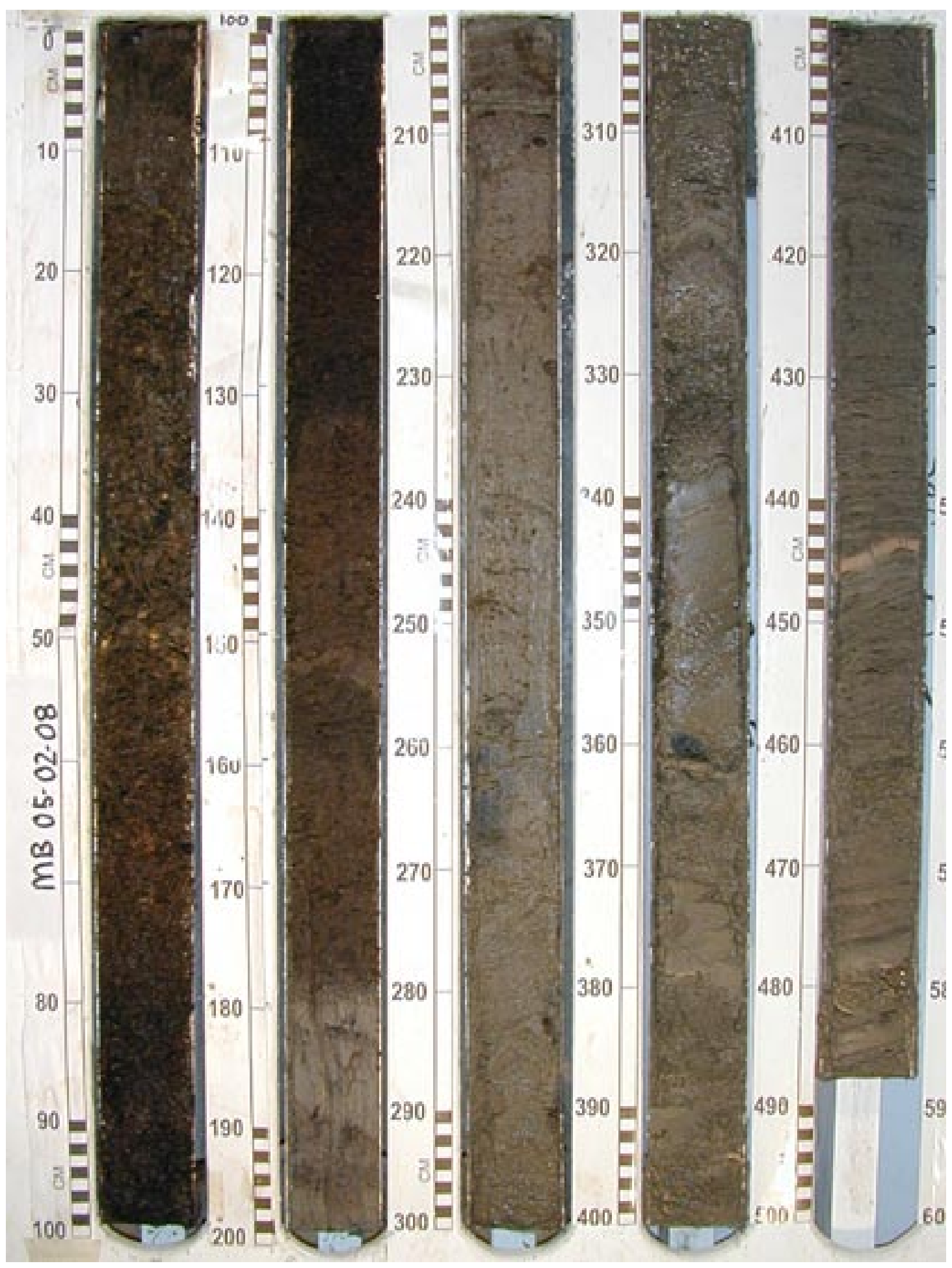




\section{Core MB 05-02-09}

Location: Madison Bay, Terrebonne Parish, LA Latitude N $29^{\circ} 20^{\prime} 54.55^{\prime \prime}$

Date cored 05/01/02

Longitude W $90^{\circ} 34^{\prime} 29.06^{\prime \prime}$

Water depth $27 \mathrm{~cm}$

Date described 06/05/02

Core length $479 \mathrm{~cm}$

Corrected (NAVD88) elevation $17 \mathrm{~cm}$

Compaction $52 \mathrm{~cm}$

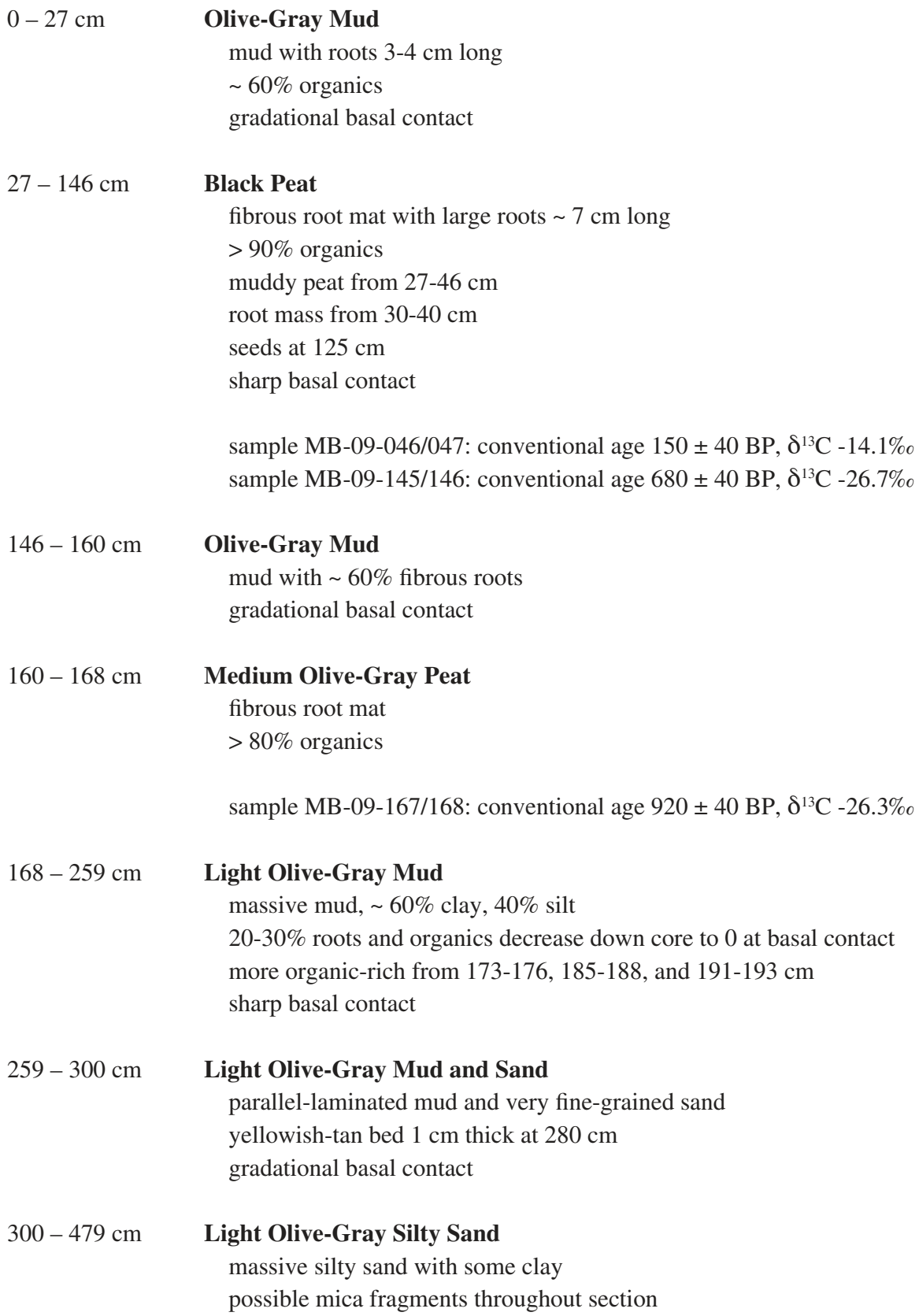

\section{Light Olive-Gray Silty Sand}

massive silty sand with some clay

possible mica fragments throughout section 


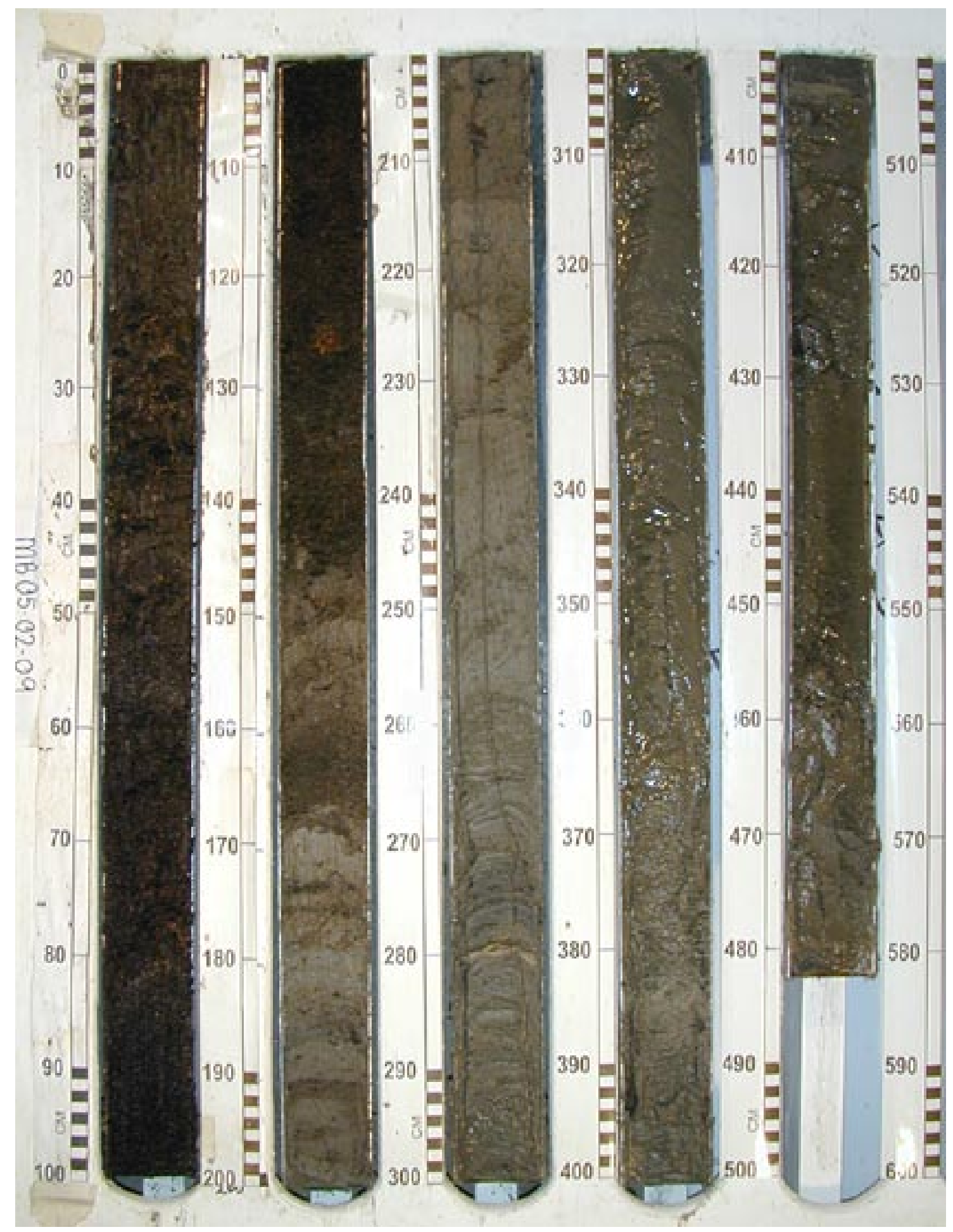




\section{Core MB 05-02-10}

Location: Madison Bay, Terrebonne Parish, LA

Latitude N 2921'56.22" Longitude W 90³4' 56.56"

Date cored 05/01/02 Date described 06/04/02

Water depth $18 \mathrm{~cm} \quad$ Corrected (NAVD88) elevation $30 \mathrm{~cm}$

Core length $432 \mathrm{~cm} \quad$ Compaction $82 \mathrm{~cm}$

$0-48 \mathrm{~cm} \quad$ Olive-Gray Peat

root mat with large roots, some $>4 \mathrm{~cm}$ long and $2 \mathrm{~cm}$ wide

$>85 \%$ organics

gradational basal contact

$48-153 \mathrm{~cm} \quad$ Black Peat

fibrous root mat

$>90 \%$ organics

decreasing organic content from $148-153 \mathrm{~cm}$

gradational basal contact

sample MB-10-152/153: conventional age $660 \pm 40 \mathrm{BP}, \delta^{13} \mathrm{C}-26.4 \%$ o

$153-173 \mathrm{~cm} \quad$ Light Olive-Gray Mud

massive mud, $\sim 60 \%$ clay, $40 \%$ silt

$\sim 40 \%$ organics

sharp basal contact

$173-198 \mathrm{~cm} \quad$ Black Peat

$>75 \%$ fibrous roots

gradational basal contact

sample MB-10-197/198: conventional age $970 \pm 40 \mathrm{BP}, \delta^{13} \mathrm{C}-26.5 \%$ o

$198-240 \mathrm{~cm} \quad$ Olive-Gray Mud

$\sim 40 \%$ organics decrease down core to 0 at $\sim 240 \mathrm{~cm}$

more organic-rich from 202-204 and 210-213 cm

gradational basal contact

$240-337 \mathrm{~cm} \quad$ Light Olive-Gray Mud

massive mud, $\sim 50 \%$ clay, $50 \%$ silt

large, hydrous organic cluster $3 \mathrm{~cm}$ thick and $5 \mathrm{~cm}$ wide at $336 \mathrm{~cm}$

sharp basal contact

$337-432 \mathrm{~cm}$

\section{Light Olive-Gray Silty Sand}

massive to parallel-laminated silty sand

some thicker beds of fine-grained sand

shell at $337 \mathrm{~cm}$ 


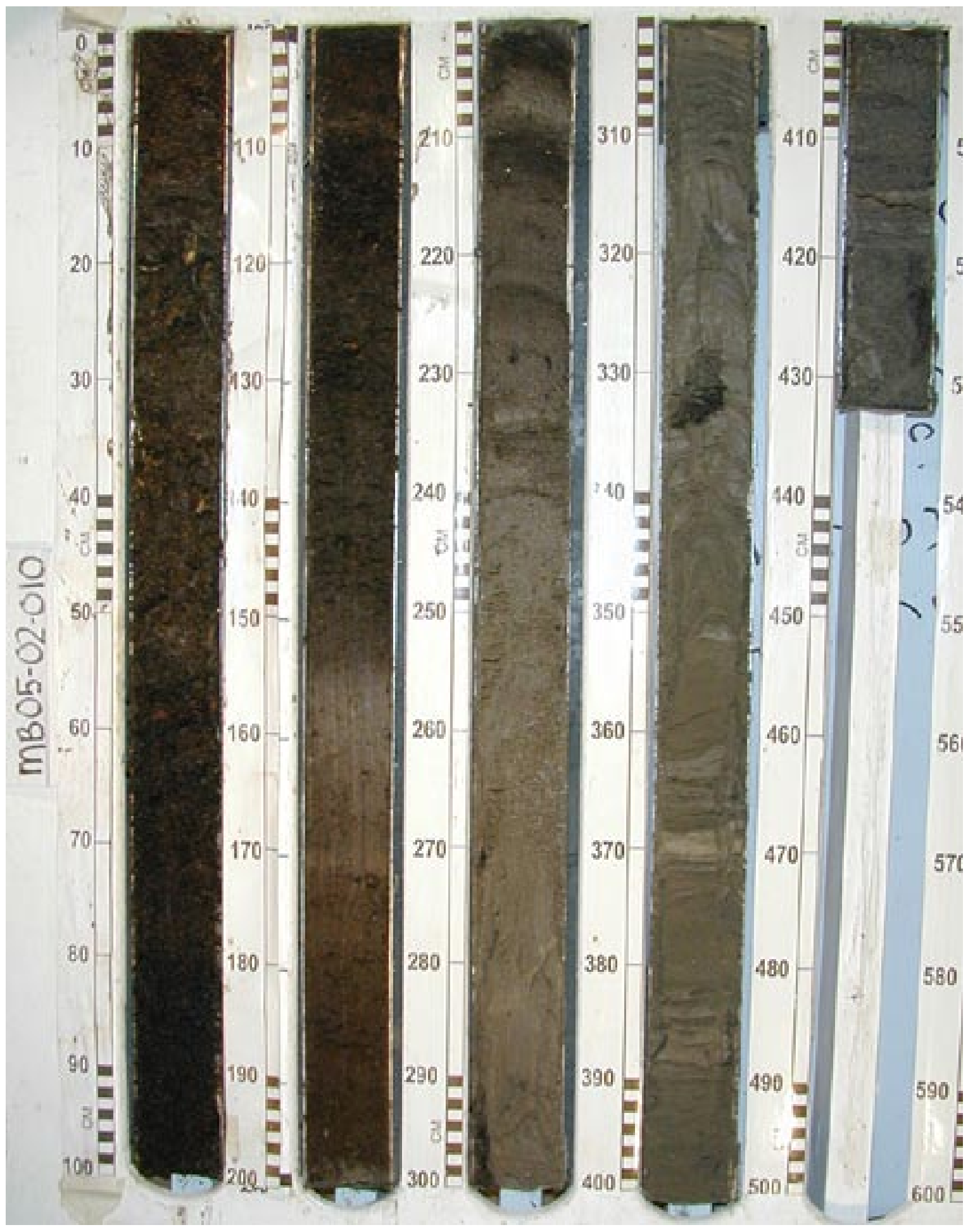




\section{Core DL03-01A}

Location: DeLarge, Terrebonne Parish, LA

Latitude N 29० 22' 48.9"

Date cored 06/27/2003

Longitude W $90^{\circ} 45^{\prime} 59.7$ '

Water depth $91 \mathrm{~cm}$

Core length $306 \mathrm{~cm}$

Date described 07/22/2003

Corrected (NAVD88) depth $49 \mathrm{~cm}$

Compaction $76 \mathrm{~cm}$

$0-28 \mathrm{~cm}$

\section{Dark Olive-Gray Peat}

depth in core barrel 13-41 cm (gap 0-13 cm)

root mat with some large roots $\sim 5 \mathrm{~cm}$ in length

$>90 \%$ organics

gradational basal contact

sample DL-01A-026/027: conventional age $510 \pm 40 \mathrm{BP}, \delta^{13} \mathrm{C}-27.4 \%$ o

\section{$28-45 \mathrm{~cm} \quad$ Olive-Gray Mud}

depth in core barrel $41-58 \mathrm{~cm}$

massive mud with some roots

$40-50 \%$ organics

gradational basal contact

$45-56 \mathrm{~cm}$

\section{Dark Olive-Gray Mud}

depth in core barrel $58-69 \mathrm{~cm}$

organic-rich mud with roots

$\sim 75 \%$ organics

gradational basal contact

$56-97 \mathrm{~cm}$

Dark Olive-Gray to Black Peat

depth in core barrel $69-110 \mathrm{~cm}$

$75-90 \%$ organics and small roots

olive-gray peat with roots not as abundant from $72-75 \mathrm{~cm}(85-88 \mathrm{~cm}$ in core barrel)

sharp basal contact

sample DL-01A-056/057: conventional age $840 \pm 40 \mathrm{BP}, \mathrm{\delta}^{13} \mathrm{C}-26.4 \%$ 。 sample DL-01A-095/096: conventional age $1050 \pm 40 \mathrm{BP}, \delta^{13} \mathrm{C}-26.9 \%$ 。

$97-117 \mathrm{~cm} \quad$ Gray to Olive-Gray Mud

depth in core barrel $110-130 \mathrm{~cm}$

mud with $\sim 25 \%$ organics

gradational basal contact

$117-277 \mathrm{~cm}$

Dark Greenish-Gray to Olive-Gray Sand and Mud

depth in core barrel 130-290 cm

sand interbedded with mud

muddy laminae are slightly deformed

small shell fragments at $201 \mathrm{~cm}(214 \mathrm{~cm}$ in core barrel)

organic clast $\sim 1.5 \mathrm{~cm}$ wide at $247 \mathrm{~cm}(260 \mathrm{~cm}$ in core barrel)

organic layer with bivalve shell fragments from $264-267 \mathrm{~cm}(277-280 \mathrm{~cm}$ in core barrel)

sharp basal contact

$277-306 \mathrm{~cm}$

Dark Greenish-Gray Mud

depth in core barrel 290-319 cm

section is muddier than overlying interbedded sand and mud

slight deformation of parallel laminations 


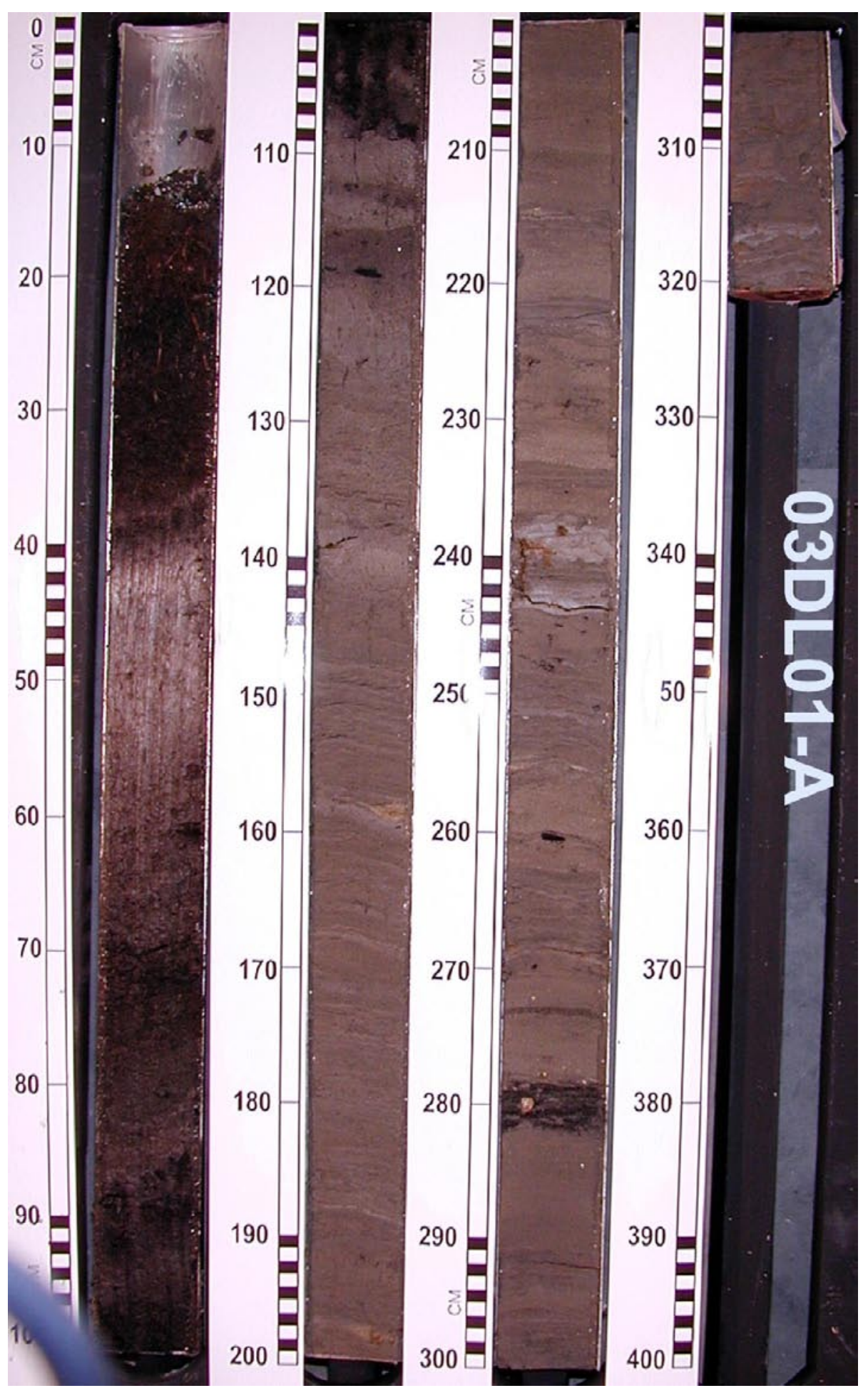




\section{Core DL03-01B}

Location: DeLarge, Terrebonne Parish, LA

Latitude N 29०22' 47.1"

Date cored 06/27/2003

Longitude W $90^{\circ} 45^{\prime} 53.9^{\prime \prime}$

Water depth $8 \mathrm{~cm}$

Date described 07/22/2003

Core length $494 \mathrm{~cm}$

Corrected (NAVD88) elevation $32 \mathrm{~cm}$

Compaction $134 \mathrm{~cm}$

$0-30 \mathrm{~cm}$

\section{Olive-Gray Peat}

root mat with some large roots $\sim 10 \mathrm{~cm}$ in length

$>90 \%$ organics

gradational basal contact is slightly deformed

$30-57 \mathrm{~cm}$

\section{Medium Gray Mud}

massive mud

large wood fragment $\sim 5 \mathrm{~cm}$ wide from $42-47 \mathrm{~cm}$

gradational basal contact

$57-110 \mathrm{~cm}$

\section{Olive-Gray Muddy Peat}

$>90 \%$ organics

gray muddy lens at $73 \mathrm{~cm}$

sharp basal contact is deformed

$110-423 \mathrm{~cm}$

\section{Light Olive-Gray Sand and Mud}

depth in core barrel 110-430 cm (gap 116-123 cm)

parallel-laminated sand and mud

average thickness of laminae 1-2 cm, some sandy horizons are thicker

large wood fragment $\sim 5 \mathrm{~cm}$ diameter and $8 \mathrm{~cm}$ long at $126 \mathrm{~cm}(133 \mathrm{~cm}$ in core barrel)

shell hash at $415 \mathrm{~cm}(422 \mathrm{~cm}$ in core barrel)

gradational basal contact

$423-431 \mathrm{~cm}$

\section{Shell Hash}

depth in core barrel $430-438 \mathrm{~cm}$

bivalve pieces

sharp basal contact

$431-456 \mathrm{~cm}$

\section{Black Organic-Rich Mud}

depth in core barrel $438-463 \mathrm{~cm}$

$>90 \%$ organics

large wood fragment from $453-456 \mathrm{~cm}(460-463 \mathrm{~cm}$ in core barrel)

gradational basal contact

$456-494 \mathrm{~cm}$

\section{Dark Olive-Gray to Greenish-Gray Mud}

depth in core barrel $463-501 \mathrm{~cm}$

$\sim 40 \%$ organics at top decreases to $<10 \%$ organics at bottom 


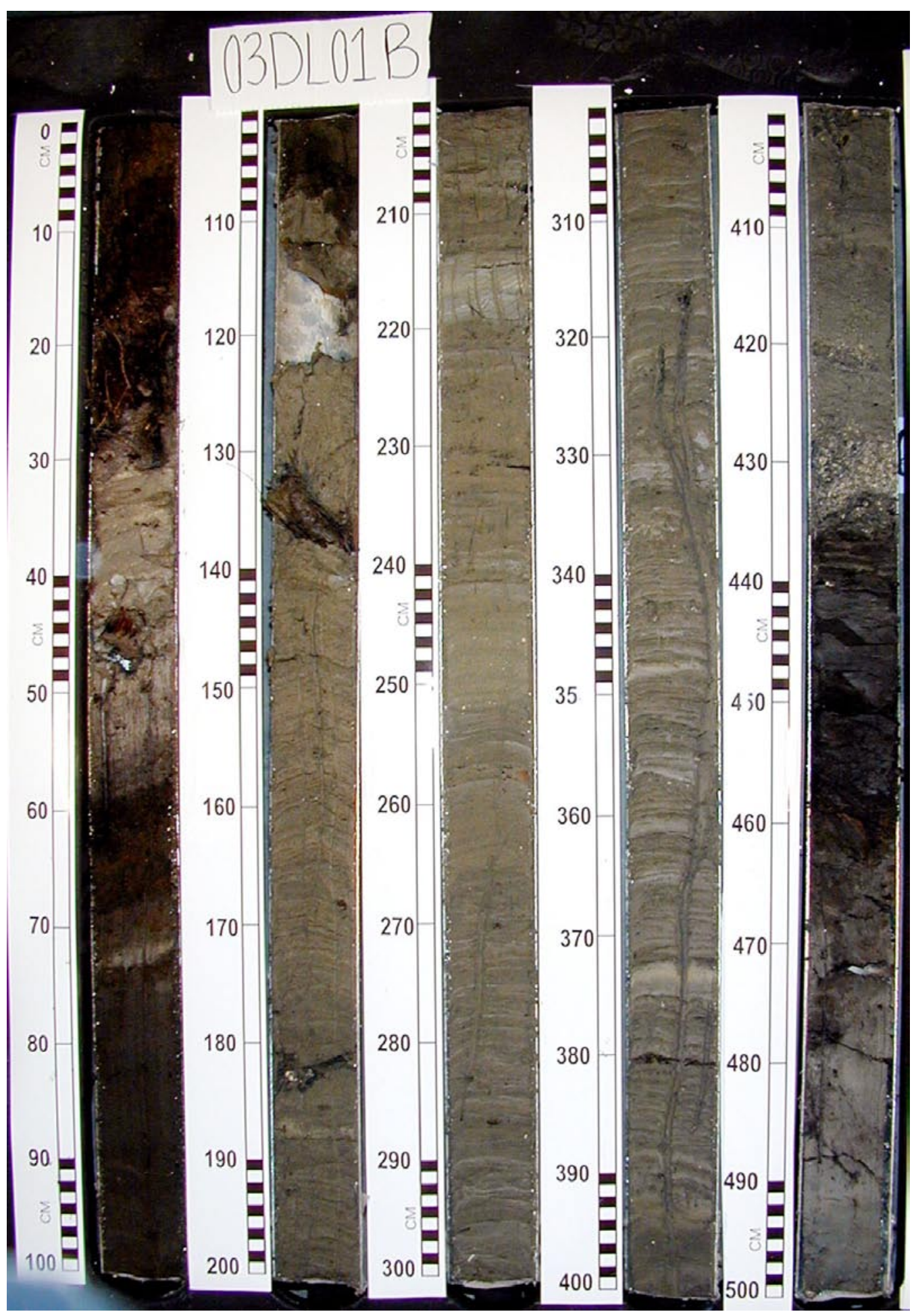




\section{Core PAC03-01A}

Location: Pointe Au Chien, Terrebonne Parish, LA

Latitude N 292 $5^{\prime} 44.3^{\prime \prime} \quad$ Longitude W 90²8' 20.3"

Date cored 06/25/2003 Date described 08/06/2003

Water depth $86 \mathrm{~cm} \quad$ Corrected (NAVD88) depth $38 \mathrm{~cm}$

Core length $429 \mathrm{~cm} \quad$ Compaction $89 \mathrm{~cm}$

$0-39 \mathrm{~cm} \quad$ Dark Olive-Gray Peat

root mat with some large roots

sharp basal contact is deformed

$39-80 \mathrm{~cm} \quad$ Olive Gray Mud

faintly laminated mud

$30-40 \%$ organics

slight deformation of laminae

$80-110 \mathrm{~cm} \quad$ Dark Olive-Gray Peat

root mat with some fibrous roots and some large root pieces

$>90 \%$ organics

gradational basal contact

sample PAC-01A-109/110: conventional age $900 \pm 40 \mathrm{BP}, \delta^{13} \mathrm{C}-27.2 \%$

$110-172 \mathrm{~cm} \quad$ Olive-Gray Mud

depth in core barrel 110-176 cm (gap 158-162 cm)

faintly laminated mud with roots and woody fragments

$\sim 25 \%$ organics

gradational basal contact

$172-196 \mathrm{~cm}$

Light Olive-Gray Silt

depth in core barrel 176-200 cm

silt with faint parallel laminations

$196-267 \mathrm{~cm}$

\section{Light Olive-Gray Silty Sand and Mud}

depth in core barrel $200-271 \mathrm{~cm}$

parallel-laminated silty sand and mud

mm-scale muddy laminae with some thicker sand and mud strata

$267-319 \mathrm{~cm}$

\section{Light Olive-Gray Silty Sand}

depth in core barrel $271-323 \mathrm{~cm}$

faintly laminated silty sand

light gray sand layer from $267-268 \mathrm{~cm}(271-272 \mathrm{~cm}$ in core barrel)

organic horizon from $188-191 \mathrm{~cm}(192-195 \mathrm{~cm}$ in core barrel)

sharp basal contact

$319-330 \mathrm{~cm}$

\section{Gray to Tan Mud}

depth in core barrel $323-334 \mathrm{~cm}$

parallel-laminated mud

sharp basal contact

$330-429 \mathrm{~cm}$

\section{Olive-Gray Mud and Sand}

depth in core barrel $334-433 \mathrm{~cm}$

parallel-laminated mud and very fine-grained sand

mm-scale laminae 


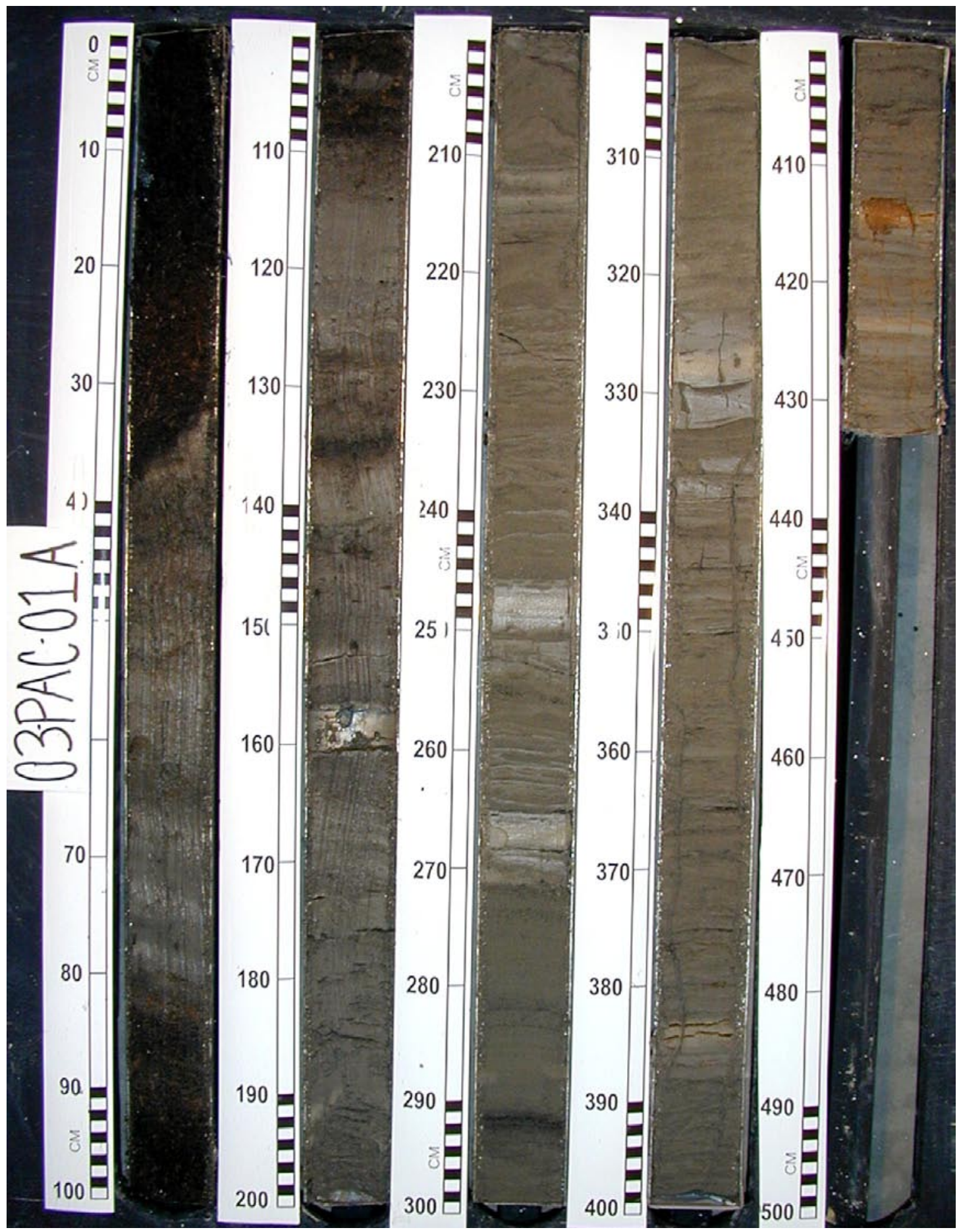




\section{Core PAC03-01B}

Location: Pointe Au Chien, Terrebonne Parish, LA

Latitude N $29^{\circ} 25^{\prime} 44.3^{\prime \prime} \quad$ Longitude W $90^{\circ} 28^{\prime} 19.1$ "

Date cored 06/25/2003 Date described 12/12/2003

Water depth $8 \mathrm{~cm} \quad$ Corrected (NAVD88) elevation $39 \mathrm{~cm}$

Core length $620 \mathrm{~cm} \quad$ Compaction $100 \mathrm{~cm}$

$0-26 \mathrm{~cm} \quad$ Dark Olive-Gray to Black Peat

root mat with large roots $\sim 5 \mathrm{~cm}$ long

sharp basal contact is slightly deformed

sample PAC-01B-025/026: conventional age $280 \pm 40 \mathrm{BP}, \mathrm{\delta}^{13} \mathrm{C}-26.1 \%$ o

$26-80 \mathrm{~cm}$

$80-103 \mathrm{~cm}$

$103-163 \mathrm{~cm}$

$163-250 \mathrm{~cm}$

$250-265 \mathrm{~cm}$

$265-308 \mathrm{~cm}$

$308-329 \mathrm{~cm}$

\section{Dark Olive-Gray to Medium Gray Mud}

massive mud

$\sim 50 \%$ organics

color change from dark olive-gray to medium gray at $62 \mathrm{~cm}$

gradational basal contact is slightly deformed

\section{Dark Olive-Gray to Black Peat}

fibrous root mat

$>90 \%$ organics

sharp basal contact is slightly deformed

\section{Olive-Gray Mud}

depth in core barrel 103-183 cm (gap 158-178 cm)

faintly laminated mud

$\sim 50 \%$ organics

some deformation of laminae

sharp basal contact is deformed

\section{Olive-Gray Sand}

depth in core barrel 183-270 cm

parallel-laminated fine-grained sand with some muddy strata at top

burrows at $165 \mathrm{~cm}$ (185 $\mathrm{cm}$ in core barrel)

root fragments from $190-200 \mathrm{~cm}(210-220 \mathrm{~cm}$ in core barrel)

section is highly deformed

deformed basal contact

\section{Olive-Gray Mud}

depth in core barrel $270-285 \mathrm{~cm}$

massive mud with some organics

sharp basal contact is deformed

\section{Olive-Gray Sand}

depth in core barrel $285-328 \mathrm{~cm}$

laminated fine-grained sand

organic horizon at $296 \mathrm{~cm}(316 \mathrm{~cm}$ in core barrel)

sharp basal contact is deformed

\section{Olive-Gray Mud}

depth in core barrel $328-349 \mathrm{~cm}$ massive mud with silty stringers deformation throughout section 
$329-620 \mathrm{~cm}$

Olive-Gray Mud and Sand

depth in core barrel $349-640 \mathrm{~cm}$

parallel-laminated mud and fine-grained sand

grain size decreases down core from 480-640 cm (500-640 cm in core barrel)

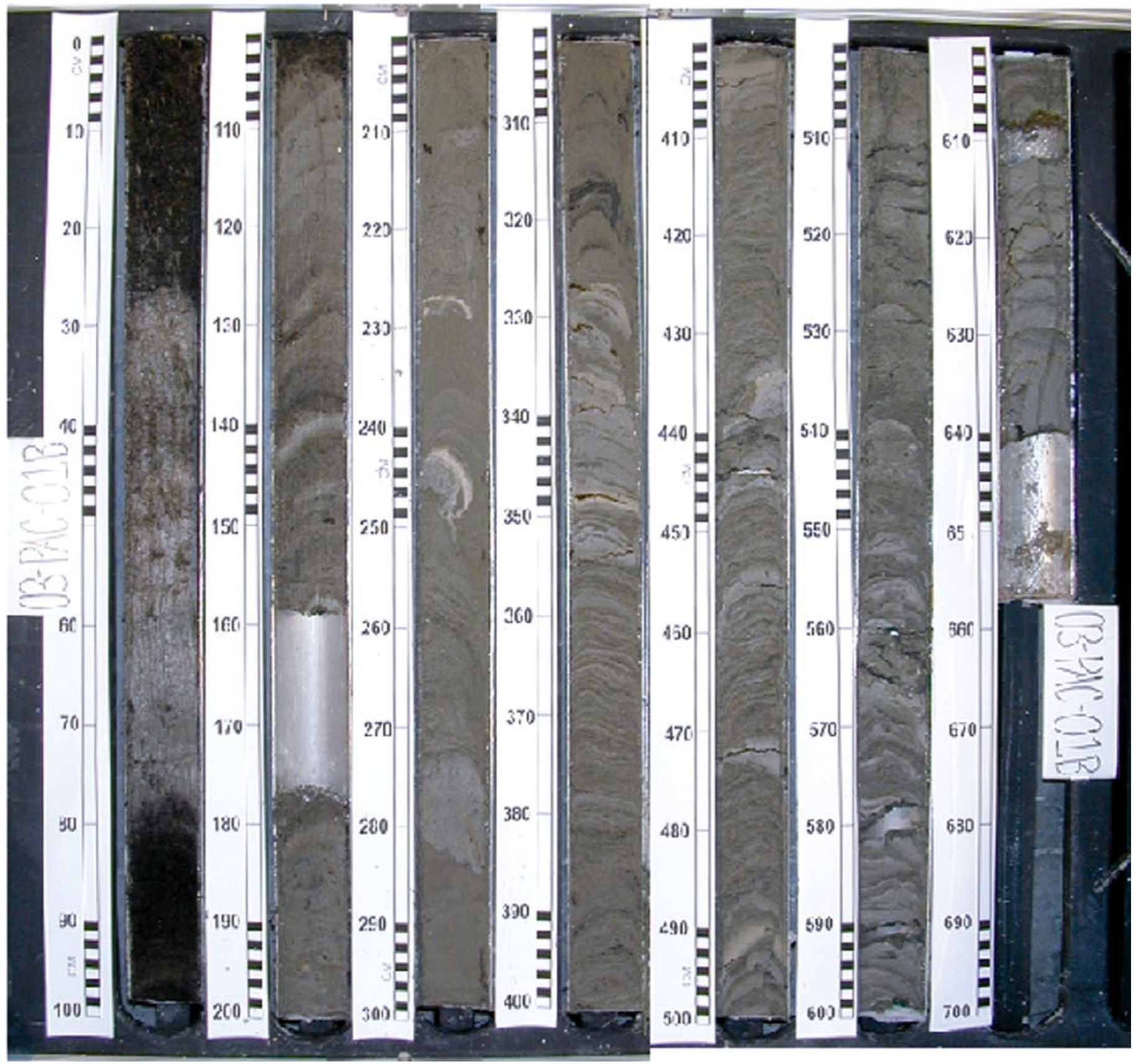




\section{Core PAC03-02A}

Location: Pointe Au Chien, Terrebonne Parish, LA

Latitude N 29 25'39.2" Longitude W 90'28'41.9"

Date cored 06/25/2003 Date described 08/06/2003

Water depth $86 \mathrm{~cm} \quad$ Corrected (NAVD88) depth $41 \mathrm{~cm}$

Core length $406 \mathrm{~cm} \quad$ Compaction $74 \mathrm{~cm}$

$0-46 \mathrm{~cm} \quad$ Dark Olive-Gray Peat

depth in core barrel 0-51 cm (gap 29-34 cm)

root mat with some large roots $8-10 \mathrm{~cm}$ long

$>90 \%$ organics

sharp basal contact

$46-62 \mathrm{~cm}$

Olive-Gray Mud

depth in core barrel 51-67 cm

massive mud

$\sim 20 \%$ organics

$62-82 \mathrm{~cm}$

Dark Olive-Gray Mud

depth in core barrel $67-87 \mathrm{~cm}$

mud with fibrous roots

$\sim 60 \%$ organics

$82-91 \mathrm{~cm} \quad$ Olive-Gray Mud

depth in core barrel $87-96 \mathrm{~cm}$

$\sim 30 \%$ organics

$91-114 \mathrm{~cm}$

Dark Olive-Gray Peat

depth in core barrel 96-119 cm

organics with some brown woody fragments

$>75 \%$ organics

sample PAC-02A-091/092: conventional age $930 \pm 40 \mathrm{BP}, \delta^{13} \mathrm{C}-27.3 \%$ o

sample PAC-02A-112/113: conventional age $980 \pm 40 \mathrm{BP}, \delta^{13} \mathrm{C}-28.0 \%$ 。

$114-205 \mathrm{~cm} \quad$ Dark Olive-Gray to Olive-Gray Mud

depth in core barrel $119-210 \mathrm{~cm}$

mud and organic-rich mud

organic strata are darker in color with wood and root fragments and fibrous root traces mud is lighter in color from $150-171 \mathrm{~cm}(155-176 \mathrm{~cm}$ in core barrel)

sharp basal contact is slightly deformed

$205-233 \mathrm{~cm}$

\section{Light Olive-Gray Mud}

depth in core barrel $210-238 \mathrm{~cm}$

faintly laminated mud

sharp basal contact

$233-363 \mathrm{~cm}$

\section{Light Olive-Gray Silty Sand}

depth in core barrel 238-368 cm

laminated silty sand with some mm-scale muddy laminae

muddy laminae more common from 315-345 (320-350 cm in core barrel)

organic lamina at $340 \mathrm{~cm}(345 \mathrm{~cm}$ in core barrel $)$ 
$363-406 \mathrm{~cm}$

Light Olive-Gray Silty Sand and Mud

depth in core barrel $368-411 \mathrm{~cm}$

laminated silty sand and mud

some oxidized strata
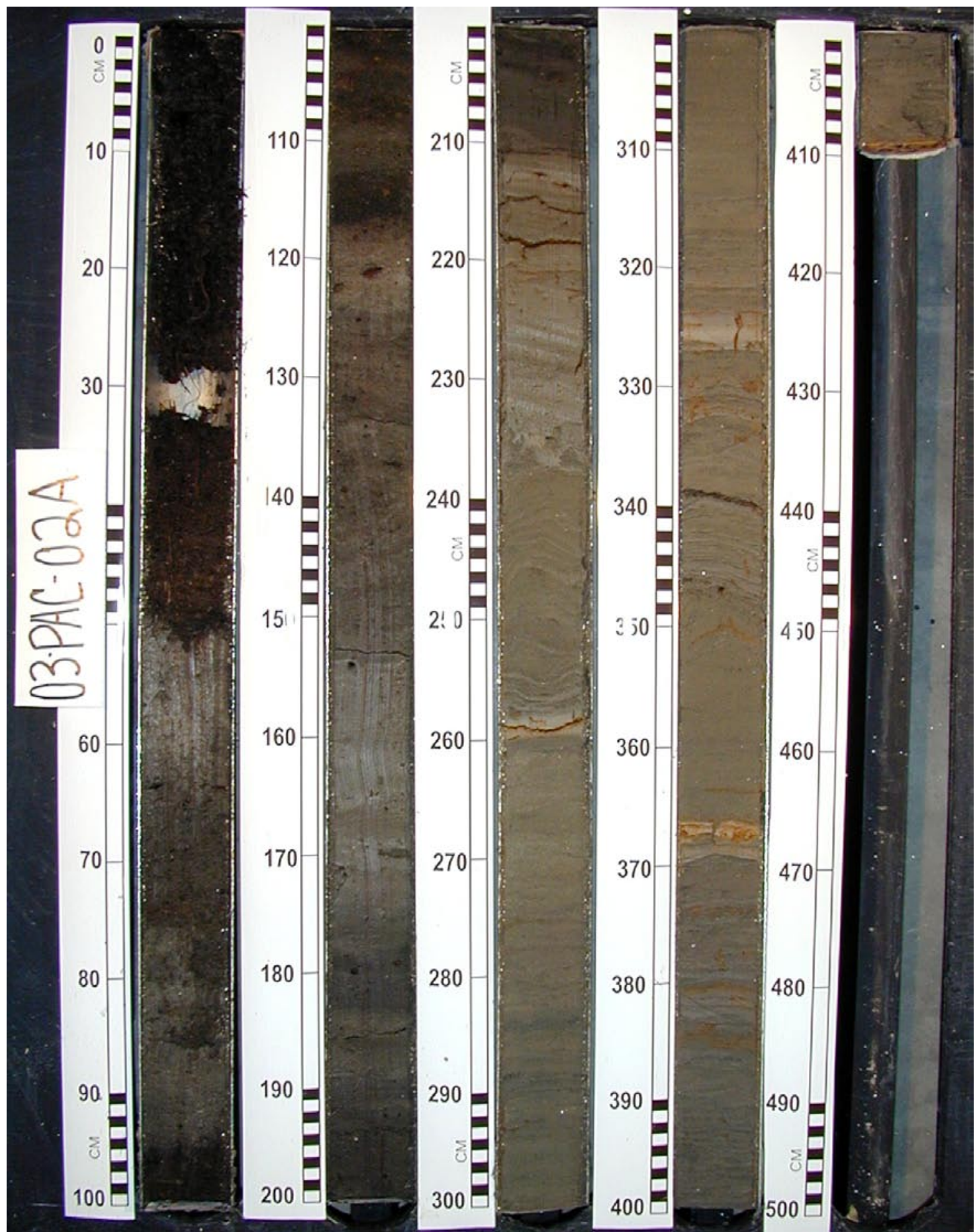


\section{Core PAC03-02B}

Location: Pointe Au Chien, Terrebonne Parish, LA

Latitude N 29 25'39.2" Longitude W 90'28'40.3"

Date cored 06/25/2003 Date described 08/07/2003

Water depth $13 \mathrm{~cm} \quad$ Corrected (NAVD88) elevation $32 \mathrm{~cm}$

Core length $555 \mathrm{~cm} \quad$ Compaction $90 \mathrm{~cm}$

$0-56 \mathrm{~cm} \quad$ Dark Olive-Gray Peat

root mat with mix of small and large roots

$>90 \%$ organics

sharp basal contact

sample PAC-02B-055/056: conventional age $430 \pm 40 \mathrm{BP}, \mathrm{\delta}^{13} \mathrm{C}-26.2 \%$ o

$56-72 \mathrm{~cm}$

\section{Olive-Gray Mud}

faintly laminated mud

$\sim 40 \%$ organics

$72-99 \mathrm{~cm}$

Dark Olive-Gray Peat

root mat with small fibrous roots

$>90 \%$ organics

sharp basal contact

$99-120 \mathrm{~cm} \quad$ Olive-Gray Mud

faintly laminated mud

$\sim 40 \%$ organics

sharp basal contact is slightly deformed

$120-164 \mathrm{~cm}$

\section{Dark Olive-Gray Organic Mud}

organic-rich mud with some small fibrous roots

$>80 \%$ organics

$164-214 \mathrm{~cm}$

\section{Olive-Gray to Light Olive-Gray Mud}

depth in core barrel 186-236 cm (gap 164-186 cm)

mud with some very fine fibrous roots

$<25 \%$ organics

gradational basal contact is deformed

$214-312 \mathrm{~cm}$

Light Olive-Gray Sandy Mud

depth in core barrel $236-334 \mathrm{~cm}$

massive sandy mud

root mass from $268-278 \mathrm{~cm}(290-300 \mathrm{~cm}$ in core barrel)

sand horizon from $278-312 \mathrm{~cm}(300-334 \mathrm{~cm}$ in core barrel)

section is deformed with possible bioturbation

$312-555 \mathrm{~cm}$

\section{Light Olive-Gray to Olive-Gray Mud and Sand}

depth in core barrel $334-577 \mathrm{~cm}$

parallel-laminated mud and very fine-grained sand

mm-scale laminae

some rust-colored stains 


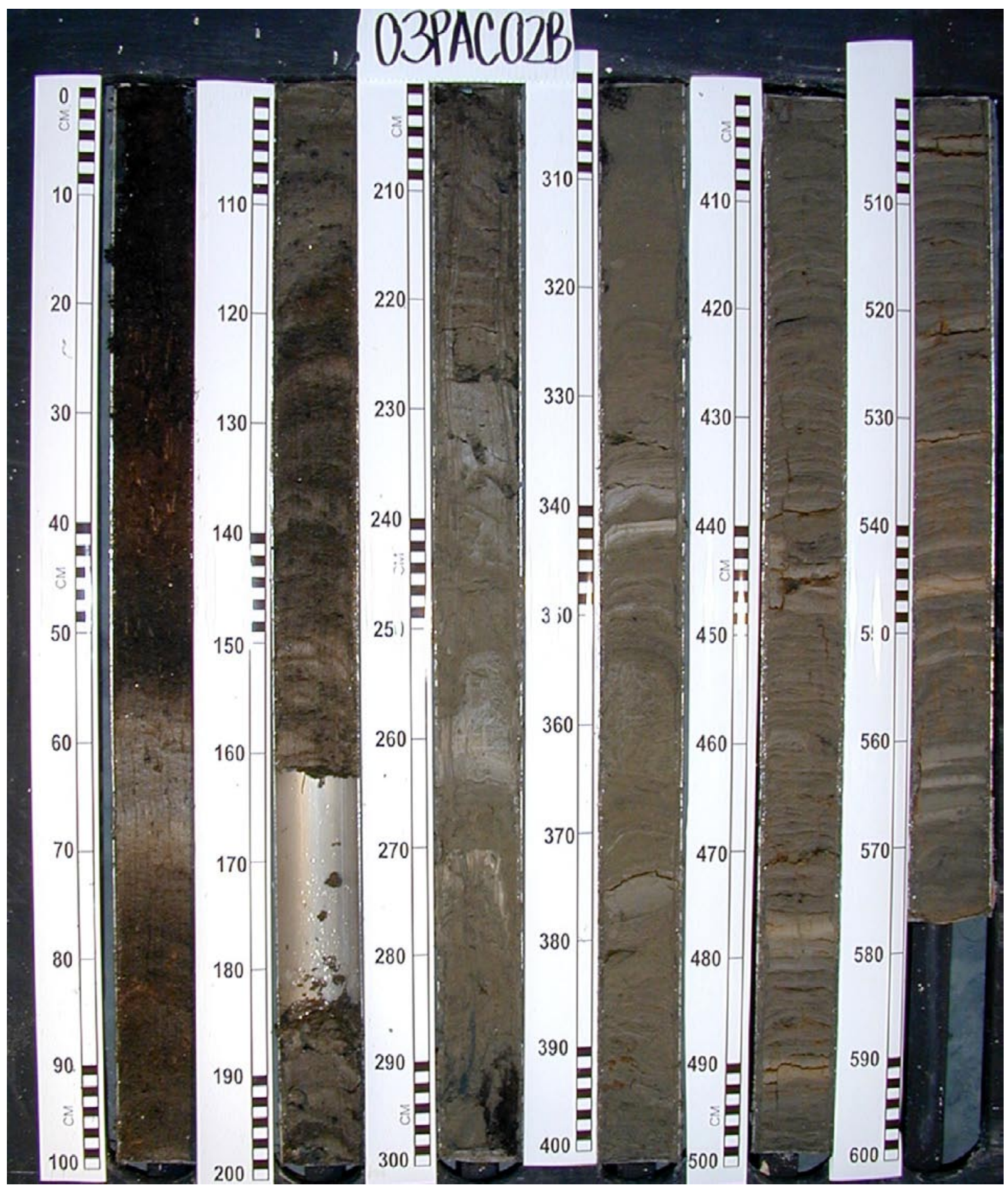




\section{Core PAC03-03}

Location: Pointe Au Chien, Terrebonne Parish, LA

Latitude N $29^{\circ} 25^{\prime} 40.4^{\prime \prime} \quad$ Longitude W $90^{\circ} 28^{\prime} 28.8^{\prime \prime}$

Date cored 09/02/2003 Date described 12/01/2003

Water depth $117 \mathrm{~cm} \quad$ Corrected (NAVD88) depth $62 \mathrm{~cm}$

Core length $492 \mathrm{~cm} \quad$ Compaction $33 \mathrm{~cm}$

$0-42 \mathrm{~cm} \quad$ Dark Olive-Gray Peat

root mat with small fibrous roots and some large roots $20-30 \mathrm{~cm}$ long

$>90 \%$ organics

sharp basal contact is deformed

$42-94 \mathrm{~cm} \quad$ Olive-Gray Mud

mud with fibrous roots

$\sim 25 \%$ organics

dark olive-gray mud, more organic-rich from $55-63 \mathrm{~cm}$

sharp basal contact

$94-101 \mathrm{~cm} \quad$ Dark Olive-Gray Peat

$\sim 90 \%$ fibrous roots

sample PAC-03-099/100: conventional age $940 \pm 40 \mathrm{BP}, \delta^{13} \mathrm{C}-27.4 \%$ o

$101-120 \mathrm{~cm} \quad$ Olive-Gray Mud

mud with some dark brown to black organic material

$\sim 25 \%$ organics

gradational basal contact

$120-129 \mathrm{~cm}$

Dark Olive-Gray Peat

$\sim 90 \%$ organics

sharp basal contact

sample PAC-03-128/129: conventional age $950 \pm 40 \mathrm{BP}, \mathrm{\delta}^{13} \mathrm{C}-19.4 \%$ o

$129-171 \mathrm{~cm}$

\section{Olive-Gray to Dark Olive-Gray Mud}

$\sim 25 \%$ organics

muddy peat from $139-150 \mathrm{~cm}, \sim 50 \%$ organics and fibrous roots

$171-185 \mathrm{~cm}$

Light Olive-Gray Mud

mud with root traces

$185-242 \mathrm{~cm}$

Light Olive-Gray Mud

massive mud

gradational basal contact

$242-323 \mathrm{~cm}$

\section{Light Gray Mud}

parallel-laminated hydrous mud with some coarser grains than overlying section some deformation of laminae

sharp basal contact

$323-355 \mathrm{~cm}$

\section{Olive-Gray Silt}

massive silt with some very fine-grained sand

sharp basal contact 
$355-492 \mathrm{~cm}$

Olive-Gray Sand and Mud

parallel-laminated very fine-grained sand and mud

some muddy strata are yellow to tan in color

slight deformation of laminae

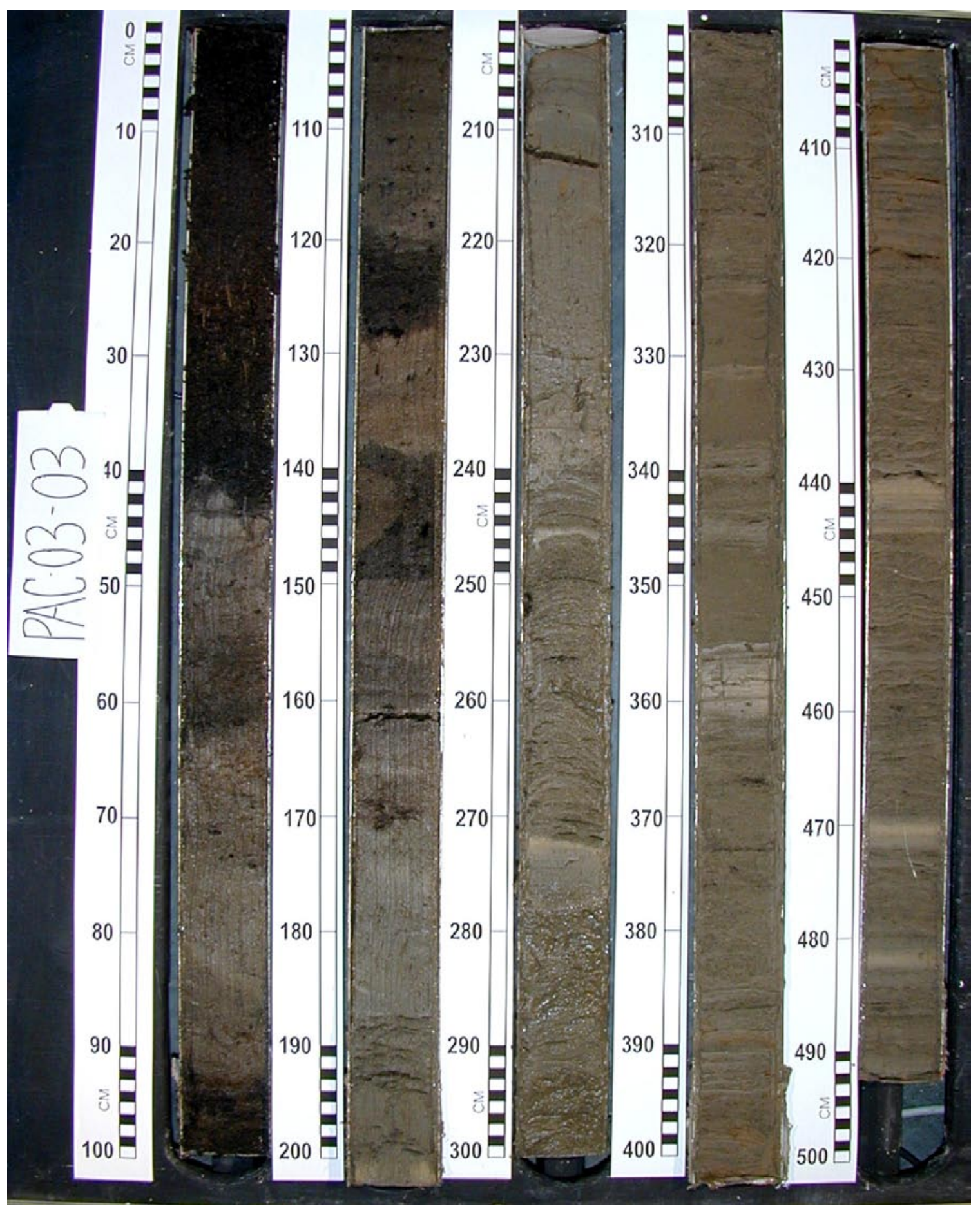




\section{Core PAC03-04}

Location: Pointe Au Chien, Terrebonne Parish, LA

Latitude N 29० 25'39.9” Longitude W 90²9'15.0”

Date cored 09/02/2003 Date described 12/05/2003

Water depth $93 \mathrm{~cm} \quad$ Corrected (NAVD88) depth $41 \mathrm{~cm}$

Core length $326 \mathrm{~cm} \quad$ Compaction $17 \mathrm{~cm}$

$0-42 \mathrm{~cm} \quad$ Dark Olive-Gray to Black Peat

fibrous root mat

$>90 \%$ organics

gradational basal contact

$42-82 \mathrm{~cm}$

Medium Gray Mud

massive mud with root fragments

$\sim 25 \%$ organics

$82-176 \mathrm{~cm}$

Olive-Gray to Light Olive-Gray Mud

massive mud

gradational basal contact

$176-210 \mathrm{~cm} \quad$ Black Peat

$>90 \%$ organics

gradational basal contact

$210-270 \mathrm{~cm}$

Black Organic Mud

massive to faintly laminated organic-rich mud

$>90 \%$ organics

sharp basal contact

$270-326 \mathrm{~cm}$

\section{Olive-Gray Mud}

faintly laminated mud

$<25 \%$ organics 


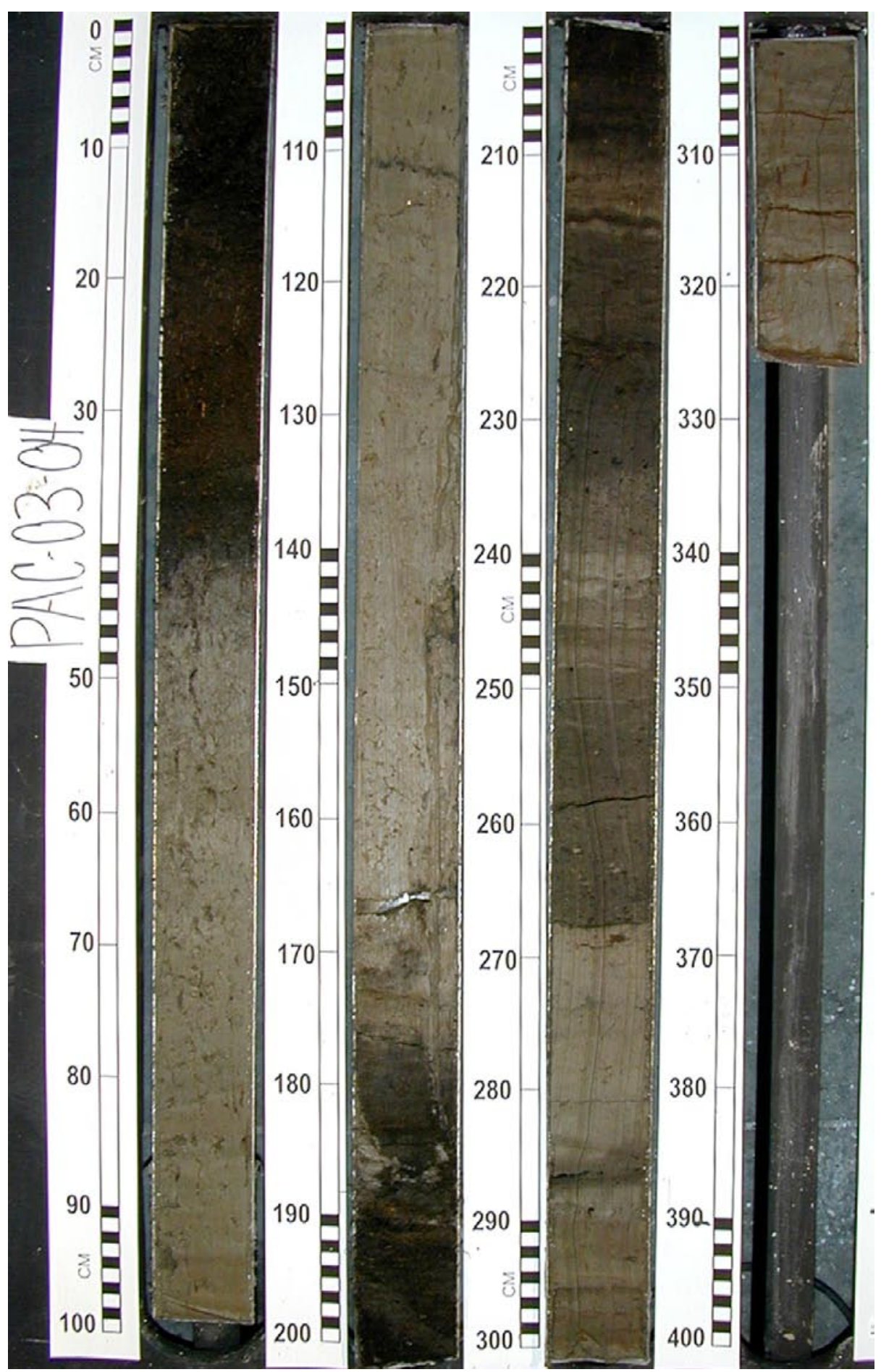




\section{Core PAC03-05}

Location: Pointe Au Chien, Terrebonne Parish, LA

Latitude N 29 25'40.9” Longitude W 90²9' 17.3”

Date cored 09/04/2003 Date described 12/09/2003

Water depth $34 \mathrm{~cm} \quad$ Corrected (NAVD88) elevation $33 \mathrm{~cm}$

Core length $502 \mathrm{~cm} \quad$ Compaction $169 \mathrm{~cm}$

$0-41 \mathrm{~cm} \quad$ Dark Olive-Gray Peat

root mat with small fibrous roots and some larger roots $\sim 5 \mathrm{~cm}$ long sharp basal contact

$41-50 \mathrm{~cm} \quad$ Black Peat

$>90 \%$ organics

gradational basal contact

$50-84 \mathrm{~cm} \quad$ Medium Dark Gray Organic Mud

massive organic-rich mud

$>75 \%$ organics

sharp basal contact is deformed

$84-116 \mathrm{~cm}$

\section{Light Olive-Gray Mud}

massive mud

$\sim 50 \%$ organics

sharp basal contact

$116-215 \mathrm{~cm}$

\section{Light Olive-Gray Mud}

massive mud with root fragments

$\sim 25 \%$ organics

$215-260 \mathrm{~cm}$

\section{Light Olive-Gray Mud}

massive mud

no organics present

$260-502 \mathrm{~cm}$

\section{Light Olive-Gray Mud and Sand}

mud interbedded with very fine-grained sand

$\mathrm{mm}$-scale laminae become more apparent below $425 \mathrm{~cm}$

burrow at $259 \mathrm{~cm}$

thicker sand strata from $320-380 \mathrm{~cm}$ and $400-425 \mathrm{~cm}$

slight deformation of laminae 


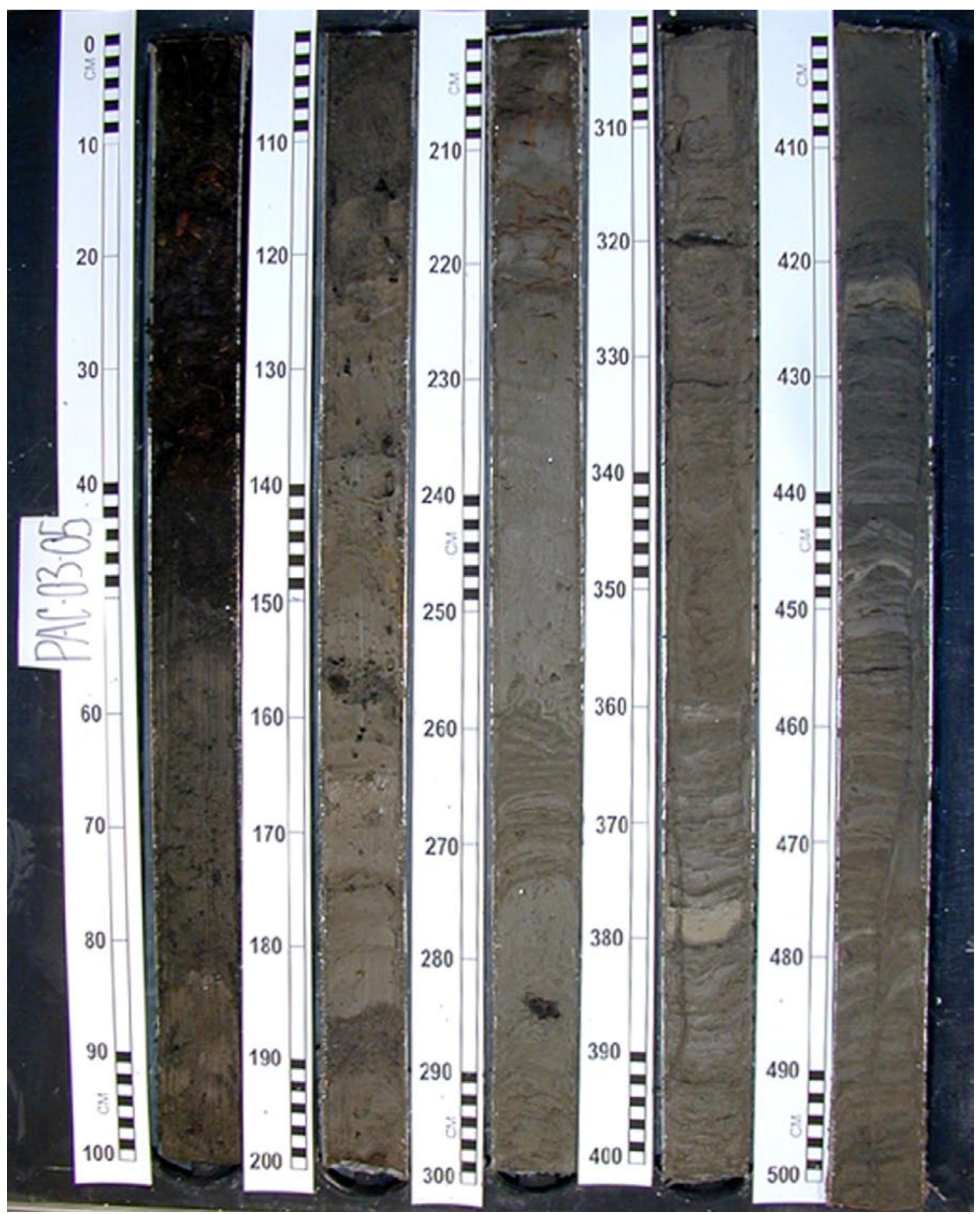


Push-Core PAC03-06

Location: Pointe Au Chien, Terrebonne Parish, LA

Latitude N $29^{\circ} 25^{\prime} 38.3^{\prime \prime} \quad$ Longitude W 90 28' 57.1"

Date cored 09/04/2003 Date described 12/05/2003

Water depth $118 \mathrm{~cm} \quad$ Corrected (NAVD88) depth $54 \mathrm{~cm}$

Core length $55 \mathrm{~cm} \quad$ Compaction N/A

$0-33 \mathrm{~cm} \quad$ Dark Olive-Gray to Black Peat

root mat with small fibrous roots

$>90 \%$ organics

$33-52 \mathrm{~cm} \quad$ Medium Gray Mud

massive mud with some roots

$\sim 25 \%$ organics

$52-55 \mathrm{~cm} \quad$ Dark Olive-Gray Peat

fibrous root mat

$>90 \%$ organics 


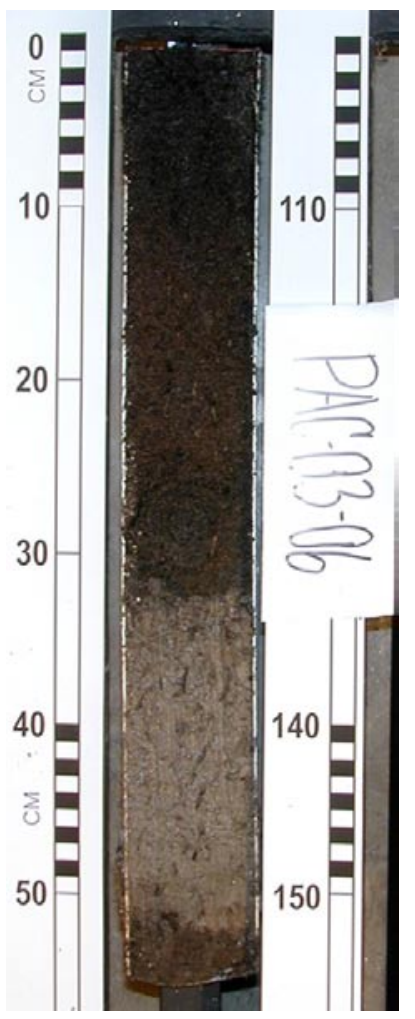




\section{Core SM03-01A}

Location: Sulphur Mine at Bully Camp Field, Terrebonne Parish, LA

Latitude N 29 27' 53.5” Longitude W 90²3' 23.0”"

Date cored 06/26/2003 Date described 07/23/2003

Water depth $124 \mathrm{~cm} \quad$ Corrected (NAVD88) depth $67 \mathrm{~cm}$

Core length $537 \mathrm{~cm} \quad$ Compaction $34 \mathrm{~cm}$

$0-40 \mathrm{~cm} \quad$ Dark Olive-Gray Peat

root mat with small fibrous roots

$>90 \%$ organics

$40-63 \mathrm{~cm} \quad$ Olive-Gray Peat

root mat with some mud

$\sim 70 \%$ organics

more organic-rich from 44-48 and 51-60 cm

$63-142 \mathrm{~cm} \quad$ Olive-Gray Mud

up to $50 \%$ organics, with decreasing organic content downward

$142-216 \mathrm{~cm}$

\section{Light Olive-Gray Mud}

massive mud

sharp basal contact

$216-273 \mathrm{~cm}$

\section{Light Olive-Gray Sand}

massive very fine-grained sand with some muddy laminations sharp contacts between sand and mud laminae

organic horizon from $246-247 \mathrm{~cm}$

$273-416 \mathrm{~cm}$

\section{Olive-Gray Mud and Sand}

parallel-laminated mud and very fine-grained sand

some laminae are rusty in color

possible bioturbation from $300-310 \mathrm{~cm}$

organics and wood at $340 \mathrm{~cm}$

shell layer with whole bivalves and shell fragments at $399 \mathrm{~cm}$

$416-537 \mathrm{~cm}$

\section{Olive-Gray Mud and Silt}

mud with faint parallel silty laminations and some thin sand lenses wood pieces at $417 \mathrm{~cm}$

shell fragments at 430, 446, 453, and $515 \mathrm{~cm}$

rust-colored mud from $500-537 \mathrm{~cm}$, may be from core barrel 


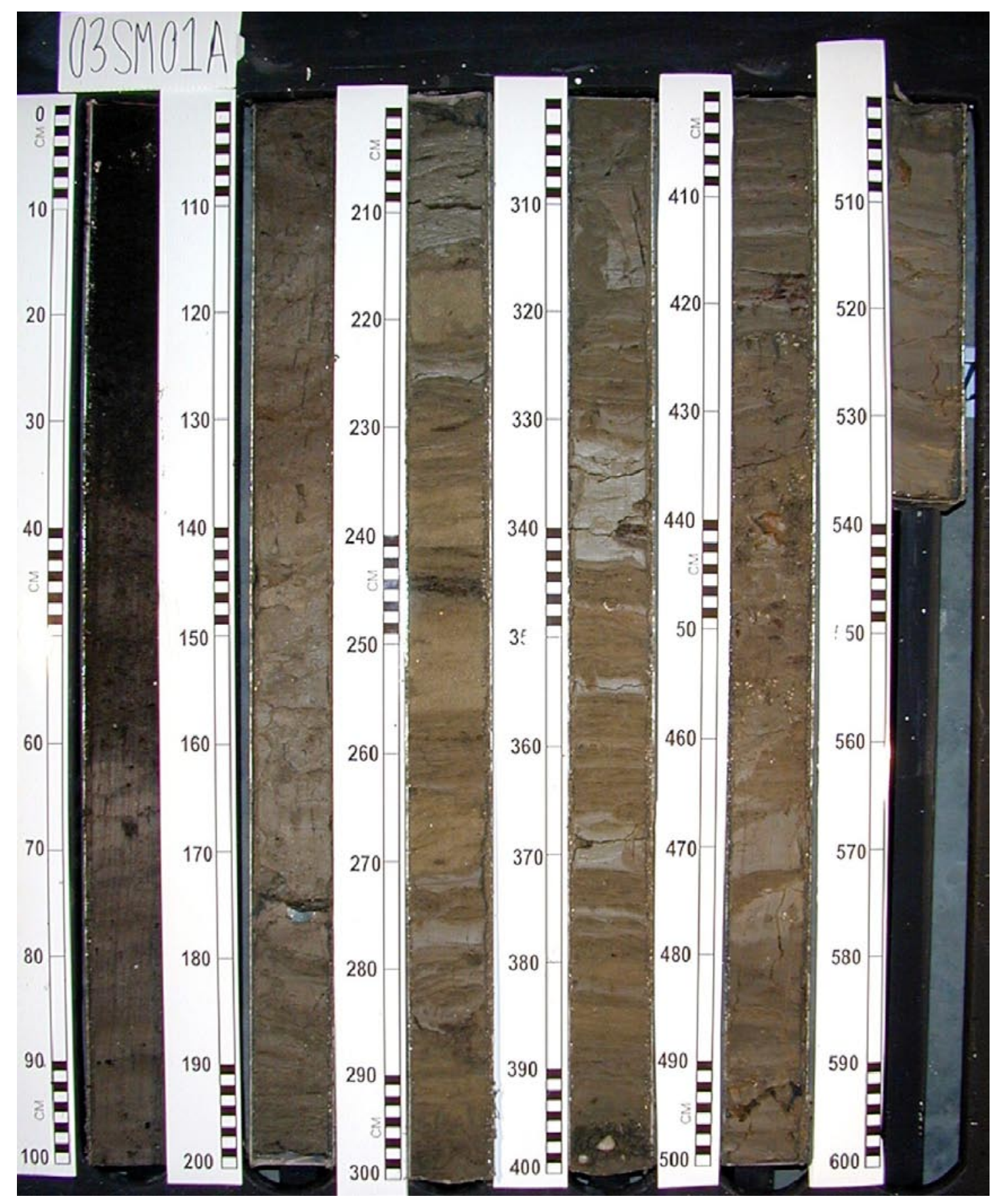




\section{Core SM03-01B}

Location: Sulphur Mine at Bully Camp Field, Terrebonne Parish, LA

Latitude N 292 $27^{\prime}$ 54.2” Longitude W 90²3' 25.4"

Date cored 06/26/2003 Date described 07/28/2003

Water depth $1 \mathrm{~cm} \quad$ Corrected (NAVD88) elevation $55 \mathrm{~cm}$

Core length $724 \mathrm{~cm} \quad$ Compaction $81 \mathrm{~cm}$

$0-12 \mathrm{~cm} \quad$ Dark Olive-Gray Peat

root mat with large, loosely compacted roots

$>90 \%$ organics

$12-27 \mathrm{~cm} \quad$ Olive-Gray Mud

mud with roots, including some large pieces $3-5 \mathrm{~cm}$ long

$\sim 25 \%$ organics

$27-73 \mathrm{~cm}$

Dark Olive-Gray Peat

root mat with small fibrous roots

$>90 \%$ organics

sharp basal contact is slightly deformed

sample SM-01B-027/028: conventional age $90 \pm 40 \mathrm{BP}, \delta^{13} \mathrm{C}-26.3 \%$ o

sample SM-01B-072/073: conventional age $420 \pm 40 \mathrm{BP}, \delta^{13} \mathrm{C}-27.4 \%$ o

$73-174 \mathrm{~cm} \quad$ Olive-Gray Mud

faintly laminated mud with roots and small woody fragments

$\sim 50 \%$ organics

organic laminae from $144-145$ and $150-163 \mathrm{~cm}$

gradational basal contact

$174-280 \mathrm{~cm}$

Dark Greenish-Gray Mud

slightly deformed laminated mud with some sand

section fines upward

possible burrow at $246 \mathrm{~cm}$

$280-349 \mathrm{~cm}$

Light Olive-Gray Sand

massive very fine-grained sand

roots at $290 \mathrm{~cm}$ may have been dragged downward

sharp basal contact

$349-560 \mathrm{~cm}$

Olive-Gray Mud and Sand

parallel-laminated mud with interbedded silt to very fine-grained sand

some clay-rich horizons have a rusty color, and some sand horizons are light olive-gray

bivalve shell at $480 \mathrm{~cm}$

gap from 500-528 cm - sediment fell out of core barrel where the core split and broke during extraction, lithology is assumed to be the same throughout the section

\section{$560-630 \mathrm{~cm} \quad$ Dark Olive-Gray Mud}

silty lamination at $626 \mathrm{~cm}$

gradational basal contact

$630-724 \mathrm{~cm}$

\section{Medium to Dark Gray Mud}

possible bioturbation indicated by scattered pockets of coarser grained sediments shell fragments occur throughout section; large bivalve shell $\sim 4 \mathrm{~cm}$ wide at $724 \mathrm{~cm}$ 

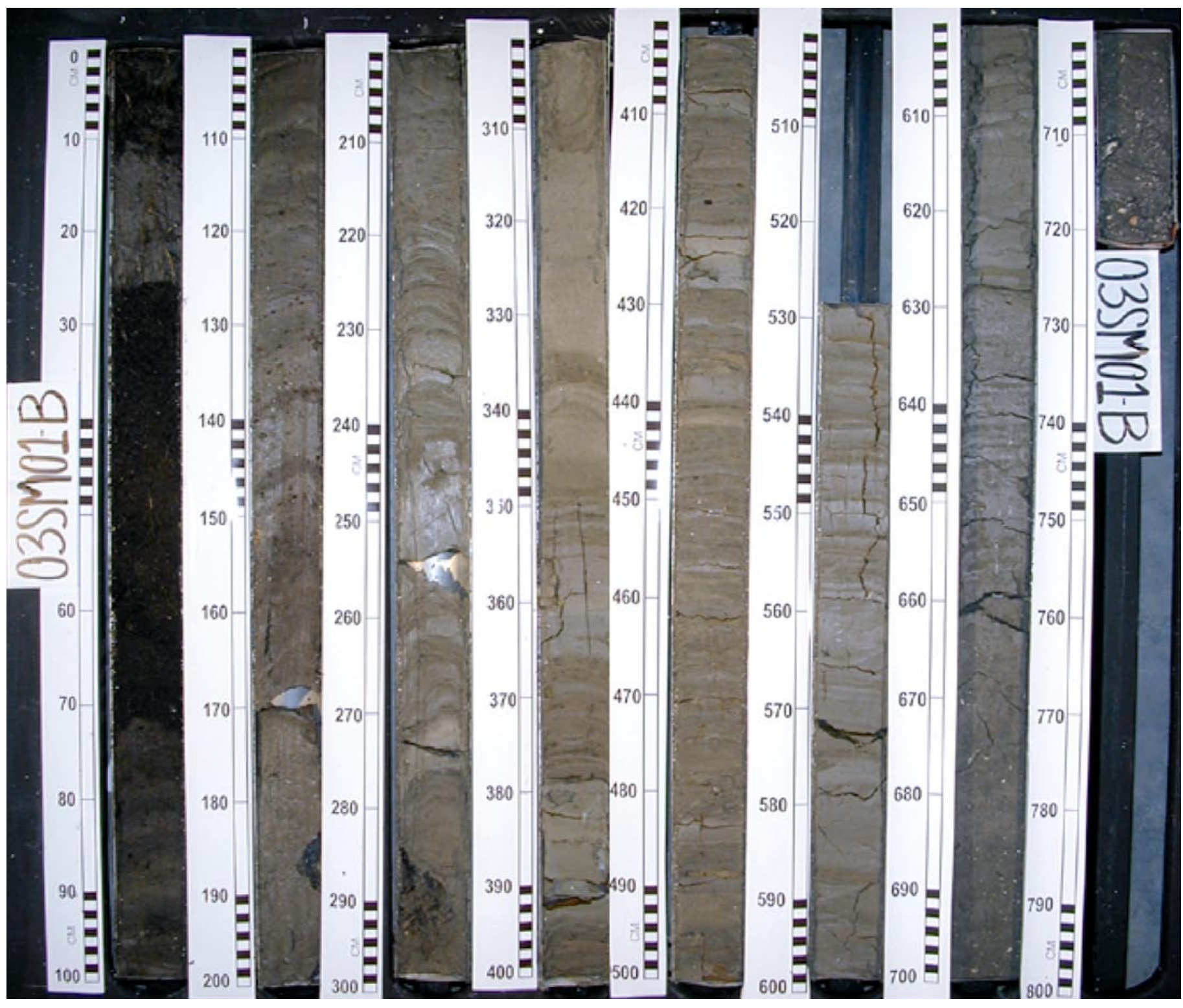


\section{Core SM03-02A}

Location: Sulphur Mine at Bully Camp Field, Terrebonne Parish, LA

Latitude N 29 27' 39.1" Longitude W 90²3'39.3”

Date cored 06/26/2003 Date described 07/23/2003

Water depth $97 \mathrm{~cm} \quad$ Corrected (NAVD88) depth $45 \mathrm{~cm}$

Core length $373 \mathrm{~cm} \quad$ Compaction $88 \mathrm{~cm}$

$0-33 \mathrm{~cm} \quad$ Olive-Gray Peat

root mat with small roots

$>90 \%$ organics

$33-100 \mathrm{~cm} \quad$ Olive-Gray Mud

$\sim 60 \%$ organics, organic content decreases down core

more organic-rich from 59-66 and 71-80 cm

$100-125 \mathrm{~cm}$

Light Olive-Gray Mud

mud with alternating light and dark-colored laminations

$125-170 \mathrm{~cm}$

\section{Light Olive-Gray Mud}

massive mud with some very fine-grained sand

possible sand-filled burrows at $150 \mathrm{~cm}$

$170-373 \mathrm{~cm}$

\section{Light Olive-Gray Sand and Mud}

massive to parallel-laminated very fine-grained sand with interbedded muddy laminae clean sand intervals with sharp contacts from 190-200, 267-278, and 290-300 cm some rust-colored (oxidized) sand and mud from $301-373 \mathrm{~cm}$ 


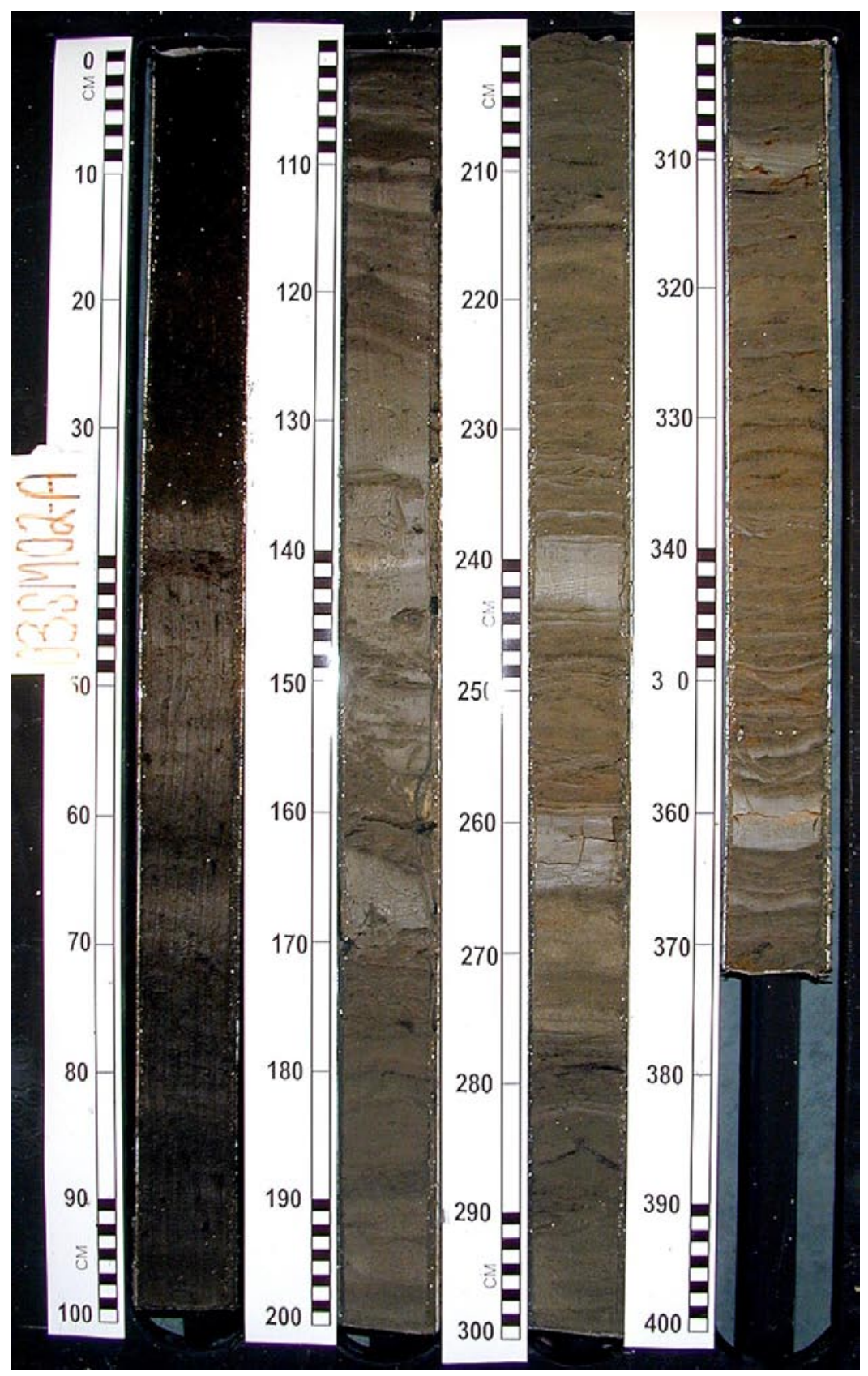




\section{Core SM03-02B}

Location: Sulphur Mine at Bully Camp Field, Terrebonne Parish, LA

Latitude N 29²7' 42.1" Longitude W 90²3'40.0”

Date cored 06/26/2003 Date described 07/24/2003

Water depth $1 \mathrm{~cm} \quad$ Corrected (NAVD88) elevation $49 \mathrm{~cm}$

Core length $521 \mathrm{~cm} \quad$ Compaction $114 \mathrm{~cm}$

$0-59 \mathrm{~cm} \quad$ Dark Olive-Gray Peat

root mat

$>90 \%$ organics

large, loosely compacted roots from $0-28 \mathrm{~cm}$

small fibrous roots, texture is more compacted from $30-59 \mathrm{~cm}$

gray muddy lens from $28-30 \mathrm{~cm}$

sample SM-02B-058/059: conventional age $450 \pm 40 \mathrm{BP}, \delta^{13} \mathrm{C}-26.5 \%$

$59-85 \mathrm{~cm}$

$85-93 \mathrm{~cm}$

$93-133 \mathrm{~cm}$

$133-163 \mathrm{~cm}$

$163-289 \mathrm{~cm}$

$289-365 \mathrm{~cm}$

$365-521 \mathrm{~cm}$

\section{Dark Olive-Gray Mud}

mud with organics and small fibrous roots

$\sim 50 \%$ organics

\section{Dark Olive-Gray Peat}

root mat

$>80 \%$ organics

sample SM-02B-085/086: conventional age $860 \pm 50 \mathrm{BP}, \delta^{13} \mathrm{C}-27.0 \%$ sample SM-02B-092/093: conventional age $900 \pm 40 \mathrm{BP}, \delta^{13} \mathrm{C}-27.3 \%$ 。

Dark Olive-Gray to Olive-Gray Mud

mud with organics and fibrous roots

$\sim 50 \%$ organics

color change at $104 \mathrm{~cm}$

\section{Olive-Gray Mud}

$\sim 25 \%$ organics

\section{Light Olive-Gray Silty Sand}

massive to parallel-laminated silty sand with some muddy laminae root fragment at $182 \mathrm{~cm}$ may have been dragged downward yellowish-tan mud from 240-244 and 276-284 cm sharp basal contact

\section{Light Olive-Gray Sand}

faintly laminated fine-grained sand

\section{Olive-Gray Mud and Sand}

parallel-laminated mud and sand organic lamina at $372 \mathrm{~cm}$ rusty color at $420 \mathrm{~cm}$, and yellowish-tan band at $420 \mathrm{~cm}$ shell fragments at $401 \mathrm{~cm}$, and bivalve shell at $498 \mathrm{~cm}$ 

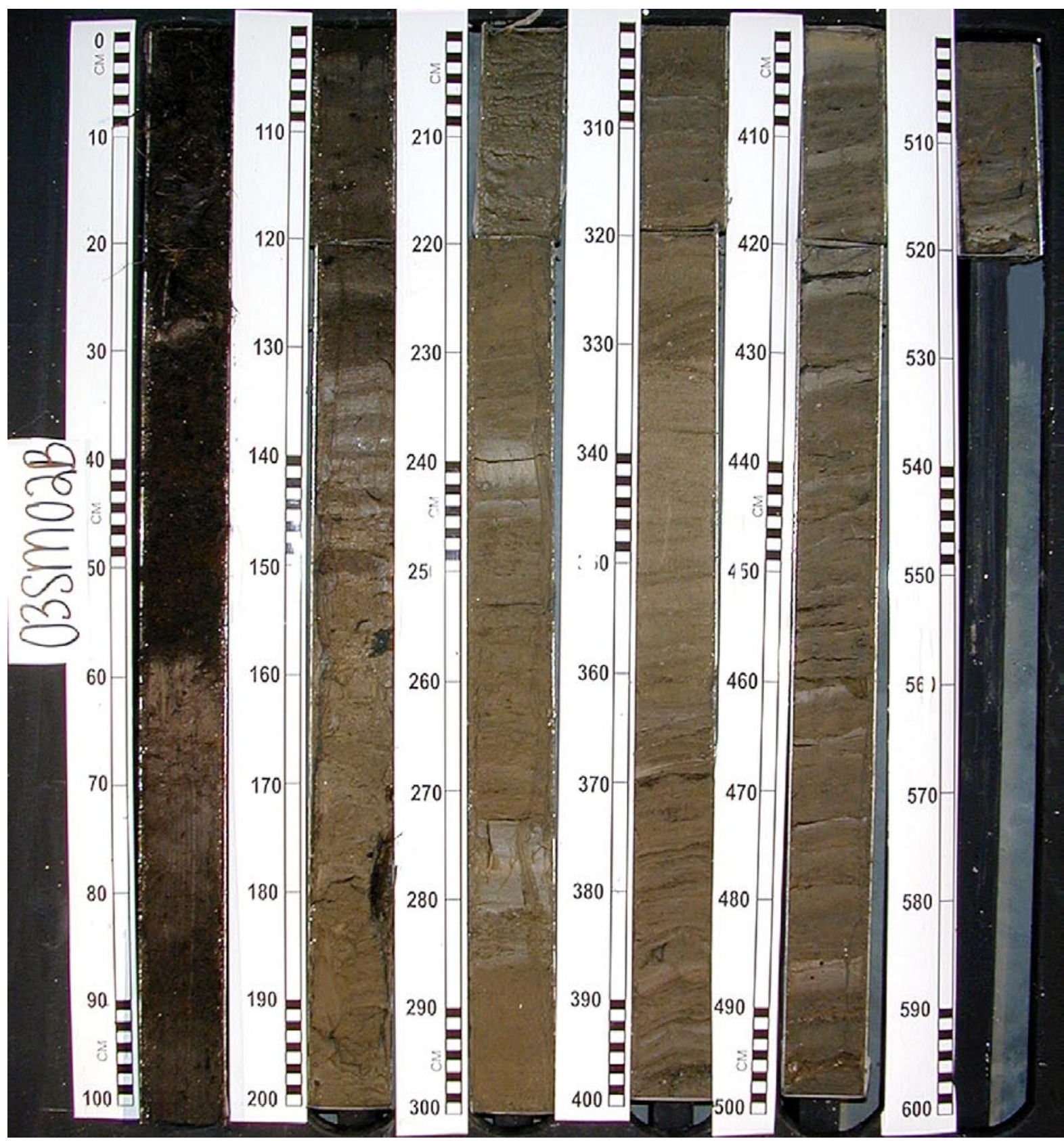


\section{Core SM03-03}

Location: Sulphur Mine at Bully Camp Field, Terrebonne Parish, LA

Latitude N 29²7'35.5" Longitude W 90²3' 28.3"

Date cored 09/04/2003 Date described 12/10/2003

Water depth $69 \mathrm{~cm} \quad$ Corrected (NAVD88) depth $8 \mathrm{~cm}$

Core length $372 \mathrm{~cm} \quad$ Compaction $83 \mathrm{~cm}$

$0-61 \mathrm{~cm} \quad$ Dark Olive-Gray to Black Peat

root mat

$>90 \%$ organics

large, loosely compacted roots from $0-34 \mathrm{~cm}$

fibrous root mat, texture is more compacted from $35-61 \mathrm{~cm}$

sharp basal contact

$61-66 \mathrm{~cm} \quad$ Dark Olive-Gray Mud

gradational basal contact

$66-75 \mathrm{~cm}$

Dark Olive-Gray to Olive-Gray Peat

fibrous root mat

$>90 \%$ organics

gradational basal contact is deformed

$75-92 \mathrm{~cm}$

Olive-Gray Mud

mud and organic-rich mud with mm-scale roots

$\sim 75 \%$ organics

sharp basal contact is slightly deformed

$92-103 \mathrm{~cm}$

Olive-Gray Peat

fibrous root mat

$>90 \%$ organics

sharp basal contact is slightly deformed

$103-122 \mathrm{~cm} \quad$ Olive-Gray Mud

mud with organics and mm-scale roots

$\sim 50 \%$ organics

sharp basal contact is deformed

$122-131 \mathrm{~cm}$

\section{Olive-Gray Peat}

root mat

$>90 \%$ organics

gradational basal contact

$131-151 \mathrm{~cm}$

\section{Olive-Gray Mud}

mud and organic-rich mud with faint parallel laminations

$\sim 75 \%$ organics

gradational basal contact

$151-170 \mathrm{~cm} \quad$ Light Olive-Gray Mud

mud with some faint laminations

$170-372 \mathrm{~cm}$

Light Olive-Gray Mud and Sand

mud interbedded with very fine-grained sand

hydrous, water-saturated sediment is deformed throughout section

some sediment missing from $300-372 \mathrm{~cm}$ 


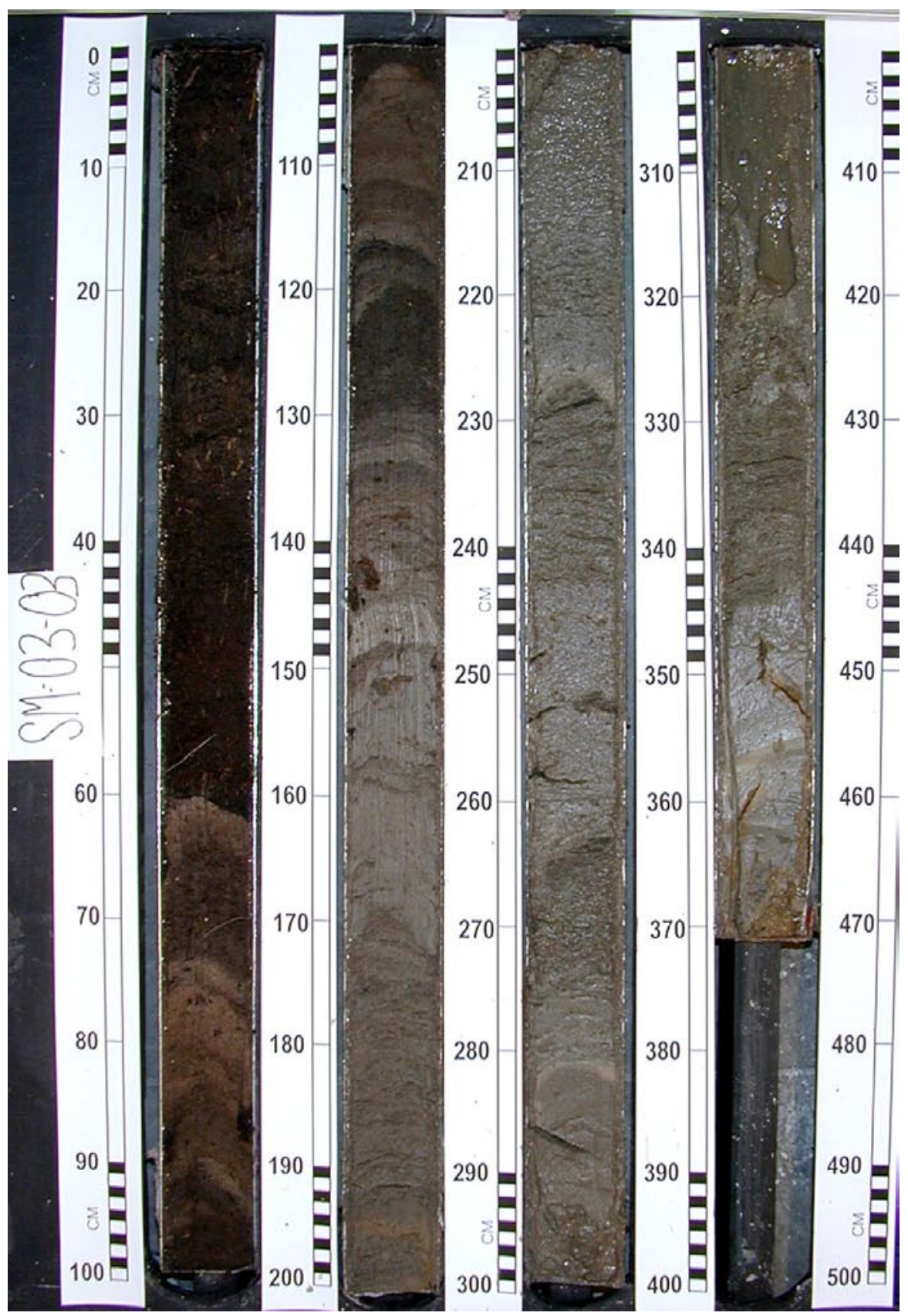




\section{Core SM03-04}

Location: Sulphur Mine at Bully Camp Field, Terrebonne Parish, LA

Latitude N 29० 27' 36.4” Longitude W 90²3' 21.9”

Date cored 09/04/2003 Date described 12/11/2003

Water depth $189 \mathrm{~cm} \quad$ Corrected (NAVD88) depth $130 \mathrm{~cm}$

Core length $584 \mathrm{~cm} \quad$ Compaction $12 \mathrm{~cm}$

$0-5 \mathrm{~cm} \quad$ Olive-Gray Silty Sand

massive silty sand with some shell fragments and organics

$\sim 50 \%$ organics

$5-29 \mathrm{~cm} \quad$ Dark Olive-Gray to Black Peat

fibrous root mat

$>90 \%$ organics

sharp basal contact

$29-34 \mathrm{~cm}$

Dark Olive-Gray Mud

massive mud

$\sim 50 \%$ organics

gradational basal contact

$34-56 \mathrm{~cm} \quad$ Dark Olive-Gray to Black Peat

$\sim 75 \%$ organics and roots

gradational basal contact

$56-155 \mathrm{~cm}$

Dark Olive-Gray to Olive-Gray Mud

massive mud

$25-50 \%$ organics

some root pieces from $60-116 \mathrm{~cm}$

sharp basal contact

$155-202 \mathrm{~cm}$

Light Olive-Gray Mud

parallel-laminated mud

burrow at $174 \mathrm{~cm}$

gradational basal contact

$202-258 \mathrm{~cm}$

Light Olive-Gray Silty Mud

parallel-laminated silty mud

slight deformation of laminae

gradational basal contact

$258-280 \mathrm{~cm}$

Light Olive-Gray Mud

mud with faint parallel laminations

sharp basal contact

$280-510 \mathrm{~cm}$

\section{Light Olive-Gray Mud and Sand}

laminated mud and very fine-grained sand

organic horizon at 310 and $354 \mathrm{~cm}$

rust-colored muddy strata from 355-360, 390-400, and 410-420 cm 
$510-584 \mathrm{~cm}$

Light Olive-Gray Mud

laminated mud

some rust-colored laminae

burrow at $511 \mathrm{~cm}$

shell fragment at $520 \mathrm{~cm}$

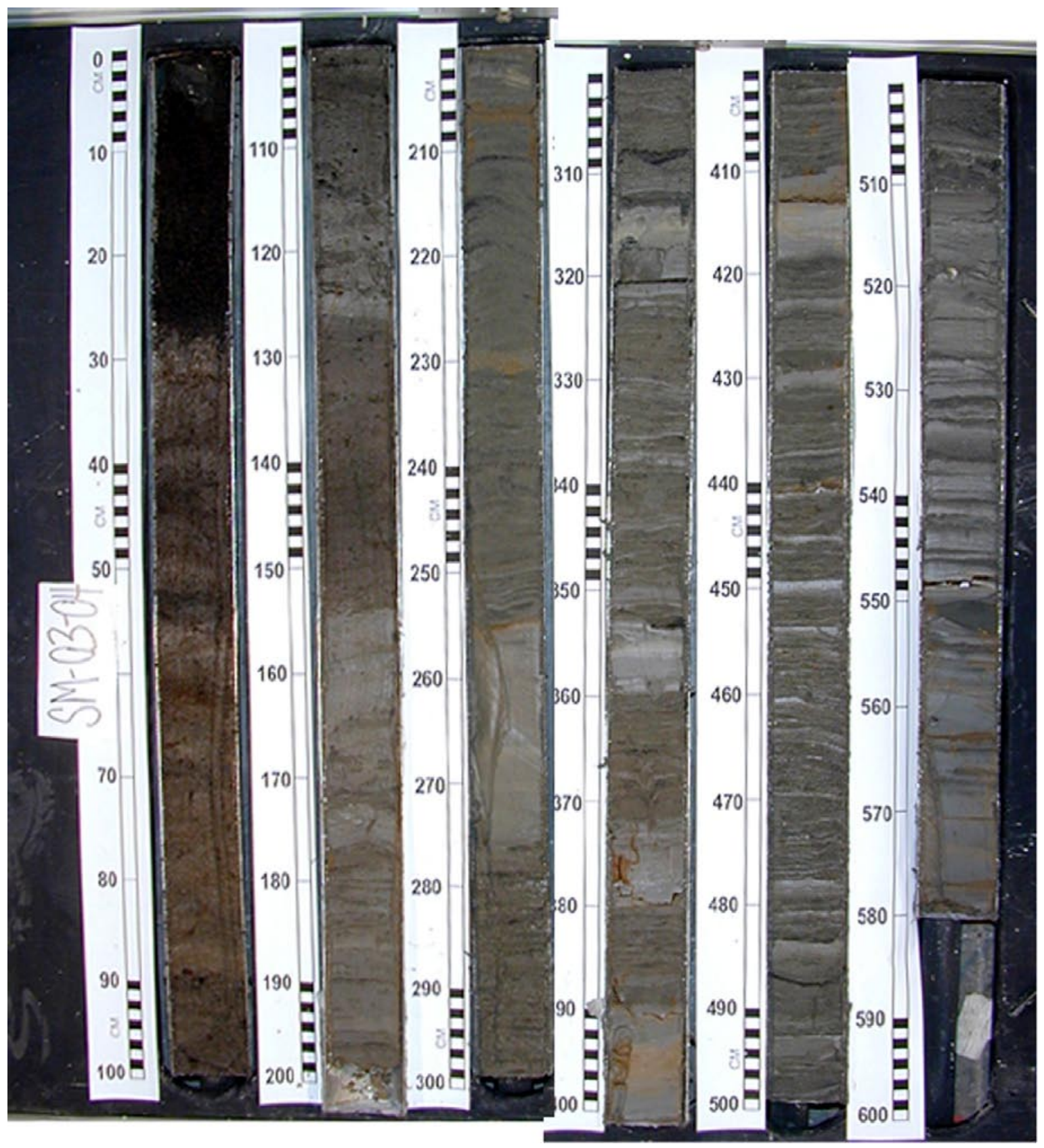




\section{Core SM03-05}

Location: Sulphur Mine at Bully Camp Field, Terrebonne Parish, LA

Latitude N 29 27' 35.4" Longitude W 90²3' 35.6"

Date cored 09/04/2003 Date described 12/10/2003

Water depth $106 \mathrm{~cm} \quad$ Corrected (NAVD88) depth $50 \mathrm{~cm}$

Core length $451 \mathrm{~cm} \quad$ Compaction $23 \mathrm{~cm}$

$0-56 \mathrm{~cm} \quad$ Dark Olive-Gray to Black Peat

fibrous root mat

$>90 \%$ organics

sharp basal contact

$56-76 \mathrm{~cm}$

\section{Olive-Gray Mud}

massive mud

$\sim 25 \%$ organics

gradational basal contact

$76-92 \mathrm{~cm}$

Dark Olive-Gray Muddy Peat

mud with roots

$\sim 80 \%$ organics

gradational basal contact

$92-140 \mathrm{~cm}$

\section{Olive-Gray Mud}

massive mud with organics and some roots present

$\sim 50 \%$ organics

faint color laminations from $131-140 \mathrm{~cm}$

$140-230 \mathrm{~cm}$

Light Olive-Gray Mud

massive mud

sharp basal contact is deformed

$230-451 \mathrm{~cm}$

\section{Light Olive-Gray Mud and Sand}

$\mathrm{mm}$-scale parallel-laminated mud and very fine-grained sand strata are deformed from $240-260 \mathrm{~cm}$

muddy layers with sharp contacts from 305-325, 340-350, and 430-440 cm

shell fragment at $402 \mathrm{~cm}$ 

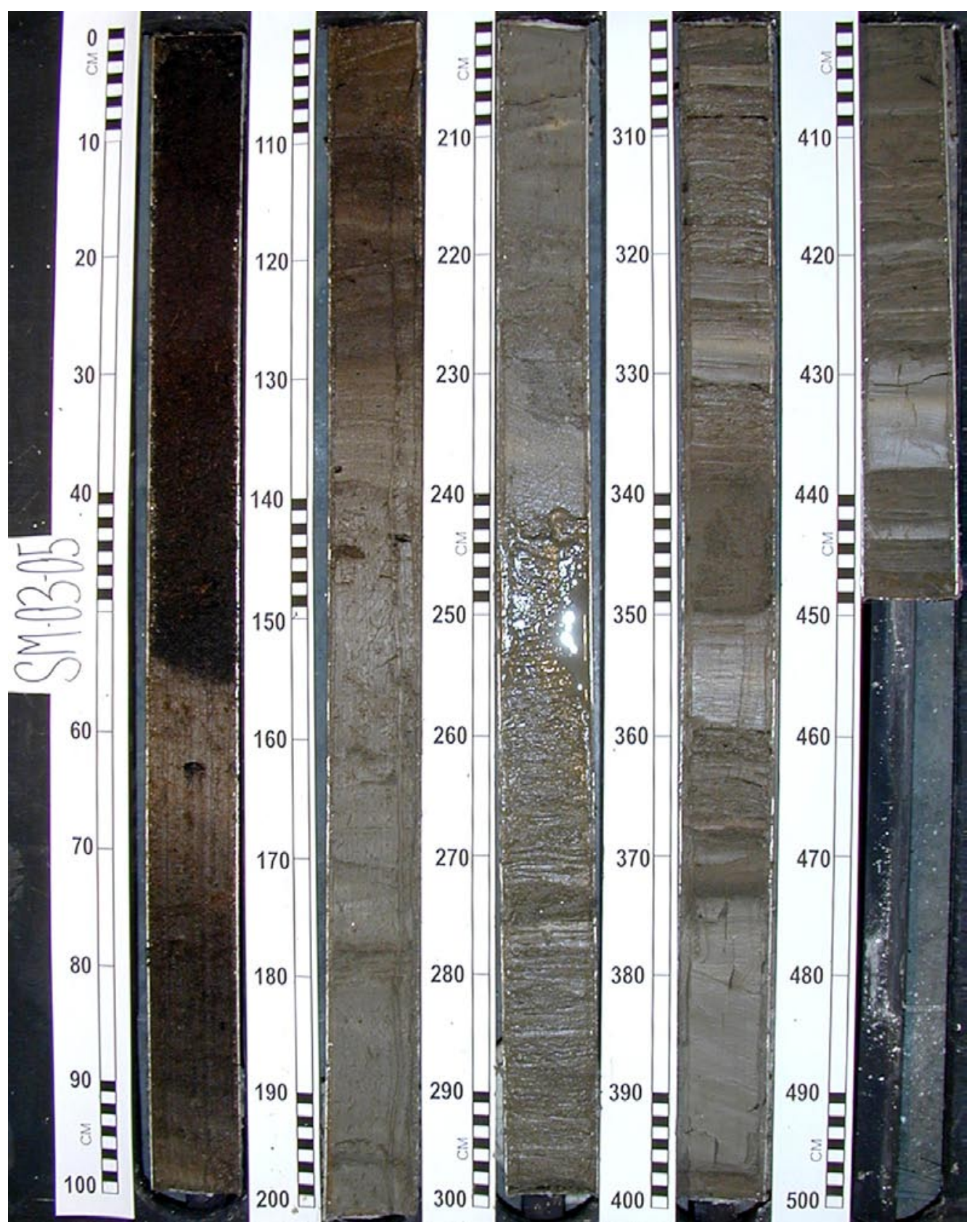


\section{APPENDIX 2: CORE SHORTENING AT BAY ST. ELAINE}

Detailed field measurements of core barrel length (inside and outside) above the sediment surface during coring operation are used to evaluate core shortening for discrete intervals. The difference between successive inside measurements represents sediment recovery, whereas the difference between successive outside measurements represents core barrel penetration. The ratio of sediment recovery to penetration represents the percent recovery for that interval.

Push-Core BSE-03-P1

$\begin{array}{cc}\text { core barrel } & 218 \mathrm{~cm} \\ \text { core length } & 74 \mathrm{~cm} \\ \text { final inside } & 144 \mathrm{~cm} \\ \text { final outside } & 37 \mathrm{~cm} \\ \text { compaction } & 107 \mathrm{~cm}\end{array}$

\begin{tabular}{cc} 
inside $(\mathrm{cm})$ & recovery $(\mathrm{cm})$ \\
\hline 198.44 & 19.56 \\
185.90 & 12.54 \\
175.26 & 10.64 \\
171.45 & 3.81 \\
161.93 & 9.52 \\
149.86 & 12.07 \\
143.83 & 6.03 \\
total & 74.17
\end{tabular}

\begin{tabular}{cc} 
outside $(\mathrm{cm})$ & penetration $(\mathrm{cm})$ \\
\hline 186.69 & 31.31 \\
165.10 & 21.59 \\
141.61 & 23.50 \\
121.29 & 20.32 \\
90.17 & 31.12 \\
63.50 & 26.67 \\
36.83 & 26.67 \\
total & 181.17
\end{tabular}

Push-Core BSE-04-P1

$\begin{array}{cc}\text { core barrel } & 145 \mathrm{~cm} \\ \text { core length } & 61 \mathrm{~cm} \\ \text { final inside } & 84 \mathrm{~cm} \\ \text { final outside } & 23 \mathrm{~cm} \\ \text { compaction } & 61 \mathrm{~cm}\end{array}$

\begin{tabular}{cc} 
inside $(\mathrm{cm})$ & recovery $(\mathrm{cm})$ \\
\hline 113.03 & 31.39 \\
102.87 & 10.16 \\
95.25 & 7.62 \\
90.49 & 4.76 \\
85.73 & 4.76 \\
83.50 & 2.22 \\
total & 60.92
\end{tabular}

\begin{tabular}{cc} 
outside $(\mathrm{cm})$ & penetration $(\mathrm{cm})$ \\
\hline 101.60 & 43.40 \\
80.33 & 21.27 \\
67.95 & 12.38 \\
52.07 & 15.88 \\
31.75 & 20.32 \\
22.54 & 9.21 \\
\cline { 2 - 2 } total & 122.46
\end{tabular}

